\title{
Site U1367
}

\author{
Expedition 329 Scientists $^{2}$
}

\section{Chapter contents}

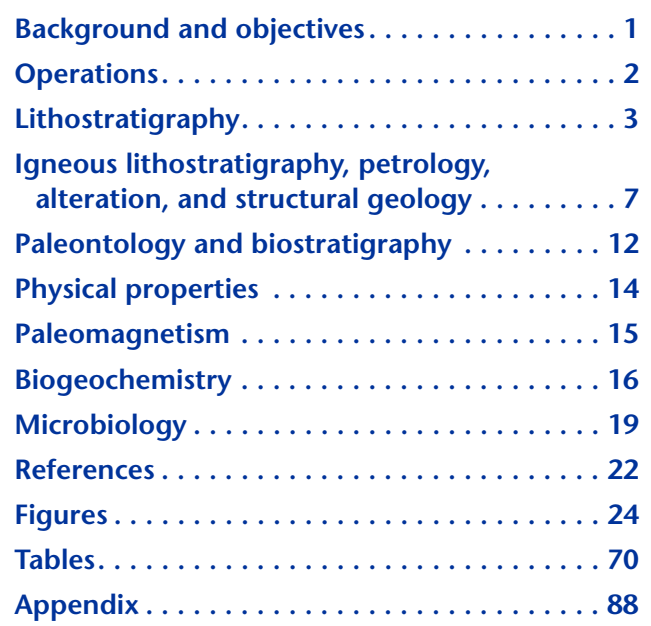

${ }^{1}$ Expedition 329 Scientists, 2011. Site U1367. In D'Hondt, S., Inagaki, F., Alvarez Zarikian, C.A., and the Expedition 329 Scientists, Proc. IODP, 329: Tokyo (Integrated Ocean Drilling Program Management International, Inc.). doi:10.2204/iodp.proc.329.105.2011

'Expedition 329 Scientists' addresses.

\section{Background and objectives}

Integrated Ocean Drilling Program (IODP) Site U1367 (proposed Site SPG-4A) was selected as a drilling target because

- Its microbial activities and cell counts were expected to be characteristic of a setting midway between the western gyre edge and the gyre center and

- Its basement age rendered it a reasonable location for testing the extent of basalt alteration and openness to flow in a thinly sedimented region of $\sim 33.5$ Ma basaltic basement.

The principal objectives at Site U1367 were

- To document the habitats, metabolic activities, genetic composition, and biomass of microbial communities in subseafloor sediment with very low total activity;

- To test how oceanographic factors (such as surface ocean productivity, sedimentation rate, and distance from shore) control variation in sedimentary habitats, activities, and communities from gyre center to gyre margin;

- To quantify the extent to which these sedimentary microbial communities may be supplied with electron donors by water radiolysis; and

- To determine how basement habitats, potential activities, and, if measurable, communities vary with basement age and hydrologic regime (from ridge crest to abyssal plain).

Site U1367 ( 4288 meters below sea level [mbsl]) is in the South Pacific Gyre within a region of abyssal hill topography trending slightly west of north $\left(355^{\circ}\right)$ with relief ranging from 100 to 150 $\mathrm{m}$ (Fig. F1). Abyssal hill spacing is $\sim 10-15 \mathrm{~km}$ with a relatively subdued fabric and broad abyssal valleys. Several seamounts are present with relatively low relief $(<300 \mathrm{~m})$ and are typically located on abyssal hill ridges. The closest seamount to the coring site is $\sim 8 \mathrm{~km}$ west of the coring site. The closest previous drilling site is Deep Sea Drilling Project (DSDP) Leg 92 Site 597, $600 \mathrm{nmi}$ away.

The coring site is within magnetic polarity Chron 13n, so the crustal age is 33.3-33.7 Ma (Gradstein et al., 2004). Based on the age of the crust and regional tectonic history (Tebbens and Cande, 1997), the crust was accreted along the Pacific-Farallon spreading center at $\sim 33.5 \mathrm{Ma}$. The calculated spreading rate from our magnetic survey suggests the crust was accreted at a fast to ul- 
trafast spreading ridge with spreading half rates of $\sim 65-70 \mathrm{~km} / \mathrm{m} . \mathrm{y}$.

Many geological and geophysical characteristics of the target site were characterized by the 2006/2007 KNOX-02RR survey expedition (D'Hondt et al., 2011) (Figs. F1, F2, F3, F4, F5, F6). The sediment is homogeneous brown clay capped by manganese nodules (D'Hondt et al., 2009).

D'Hondt et al. (2009) documented the presence of microbial cells and oxic respiration throughout the uppermost $7.2 \mathrm{~m}$ of sediment at Site U1367. Cell concentrations were approximately three orders of magnitude lower than at similar depths in previously drilled marine sediment of other regions. Net respiration was similarly much lower than at previously drilled sites. From extrapolation of dissolved oxygen content in the uppermost $7 \mathrm{~m}$ of sediment, Fischer et al. (2009) predicted that dissolved oxygen penetrates the entire sediment column, from seafloor to basement.

\section{Operations}

\section{Transit to Site U1367}

After a $100.75 \mathrm{~h}$ transit from Site U1366, covering $1019 \mathrm{nmi}$ and averaging $10.1 \mathrm{kt}$, speed was reduced and thrusters were lowered. Speed was less than expected because two of the propulsion motors were offline, one on the starboard shaft and one on the port shaft, both with failed field coils. Dynamic positioning was initiated over Site U1367 at 2304 h on 4 November 2010. The position reference was a combination of GPS signals. No acoustic beacon was deployed, but a beacon remained on standby in the event of loss of GPS satellite coverage. Whereas automatic input into the dynamic positioning system was not possible because of a system malfunction, it was possible to manually hold the vessel in position to clear the seafloor with the bottom-hole assembly (BHA) if necessary.

\section{Site U1367}

Six holes were drilled or cored at this site (Table T1). The first hole was a washdown hole drilled with the center bit in order to establish the sediment depth of 21.2 meters below seafloor (mbsf). The next four holes were cored with the advanced piston corer (APC) system. The last remaining hole was drilled and cored with the rotary core barrel (RCB) system $\sim 33.5 \mathrm{~m}$ into basement. The advanced piston corer temperature tool (APCT-3) was not deployed because of the sediment depths. Perfluorocarbon tracer (PFT) was pumped in for the entire drilling/coring interval until the last core was on deck. APC system recovery for Site U1367 was $98.1 \%$. RCB system recovery was $11.2 \%$. A total of 20 cores were attempted while coring $137.4 \mathrm{~m}$. The total length of core recovered at this site was $101.34 \mathrm{~m}$ (73.8\% recovery).

\section{Hole U1367A}

Rig floor operations commenced at $2300 \mathrm{~h}$ on 4 November 2010. The trip to the seafloor was uneventful. The top drive was picked up and the drill string was spaced out and spudded at $0740 \mathrm{~h}$ on 5 November. The PFT pump was turned on to displace the drill string with the contamination testing fluid. The washdown hole was drilled to determine depth of basement. Mudline was established at $4302.0 \mathrm{mbrf}$ by tagging with the bit. After drilling down, basement was established at 21.2 mbsf. The bit was pulled back above the seafloor, clearing the seafloor at $0810 \mathrm{~h}$ on 5 November and ending Hole U1367A.

\section{Hole U1367B}

After clearing the seafloor, the center bit was pulled by wireline, the vessel was offset $20 \mathrm{~m}$ west, and the drill string was spaced out to spud Hole U1367B. After making up the first APC core barrel, the core barrel was run to bottom on the wireline and Hole U1367B was spudded at $1000 \mathrm{~h}$ on 5 November. Seafloor depth was established with a mudline core at 4300 mbrf. APC coring continued to 22.3 mbsf. Four cores were taken with a total recovery of $22.31 \mathrm{~m}$ (100.0\% recovery). After Core $329-\mathrm{U} 1367 \mathrm{~B}-4 \mathrm{H}$, the bit was tripped back to just above the seafloor, ending Hole U1367B at $1440 \mathrm{~h}$. PFT was mixed with the drilling fluid (seawater) and pumped on all cores for contamination testing.

\section{Hole U1367C}

Hole U1367C began at $1440 \mathrm{~h}$ when the APC assembly cleared the seafloor after completing Hole U1367B. After offsetting the vessel $20 \mathrm{~m}$ north, Hole U1367C was spudded at $1520 \mathrm{~h}$ on 5 November and advanced with the APC system to $26.7 \mathrm{mbsf}$ before encountering basement. Seafloor was established at 4299.3 meters below rig floor (mbrf). PFT was mixed with the drilling fluid (seawater) and pumped on all cores for contamination testing. Four cores were taken with a total recovery of $27.01 \mathrm{~m}(101.2 \%$ recovery). The drill string was then tripped to just above the mudline, clearing the seafloor at $2005 \mathrm{~h}$ and ending Hole U1367C.

\section{Hole U1367D}

Hole U1367D began at $2005 \mathrm{~h}$ on 5 November when the APC assembly cleared the seafloor after completing Hole U1367C. After offsetting the vessel $20 \mathrm{~m}$ 
east, Hole U1367D was spudded at $2205 \mathrm{~h}$ and advanced with the APC system for four cores to 25.5 mbsf with a $24.54 \mathrm{~m}$ recovery $(96.2 \%)$. Seafloor was established at 4299.1 mbrf. PFT was mixed with the drilling fluid (seawater) and pumped on all cores for contamination testing. The drill string was tripped to just above the mudline, clearing the seafloor at 0255 $h$ on 6 November and ending Hole U1367D.

\section{Hole U1367E}

Hole U1367E began at $0255 \mathrm{~h}$ on 6 November when the APC assembly cleared the seafloor after completing Hole U1367D. After making up the first APC core barrel, the core barrel was run to bottom on the wireline and Hole U1367E was spudded at $0340 \mathrm{~h}$. Seafloor depth was established with a mudline core at 4298.7 mbrf. The APC system was used to take three cores to 24.4 mbsf with a $23.15 \mathrm{~m}$ recovery $(94.9 \%)$. PFT was mixed with the drilling fluid (seawater) and pumped on all cores for contamination testing. The drill string was tripped to the surface, clearing the rotary table at $1400 \mathrm{~h}$ and ending Hole U1367E.

\section{Hole U1367F}

After a $20 \mathrm{~m}$ offset to the south, Hole U1367F began on 6 November at $1400 \mathrm{~h}$ when the bit cleared the rotary table after tripping out of Hole U1367E. The BHA was set back, the APC bit was removed, and the rotary core bit and rotary coring system were assembled in preparation for running the new RCB BHA. The BHA was run into the hole followed by the drill pipe. The top drive was picked up and the drill string was spaced out to spud Hole U1367F. Water depth was recorded at 4300 mbrf using the BHA tag depth. The center bit was deployed and Hole U1367F was spudded at $2345 \mathrm{~h}$. At $17 \mathrm{mbsf}$, the center bit was pulled and the RCB was dropped and coring began. $\mathrm{RCB}$ coring continued from 17 to $55.5 \mathrm{mbsf}$ with poor recovery. A total of $38.5 \mathrm{~m}$ was cored with a recovery of $4.33 \mathrm{~m}$ of core. RCB system recovery in Hole U1367F was $11.2 \%$. PFT was mixed with the drilling fluid (seawater) and pumped on all cores for contamination testing. Microspheres were also deployed on all RCB cores in Hole U1367E. The drill string was tripped back to the rig floor and secured for the $793 \mathrm{nmi}$ transit to the next site, ending Hole U1367F and Site U1367 at 0545 h on 9 November.

\section{Lithostratigraphy}

The sediment at Site U1367 is primarily clay and ooze. The principal components of the clay are smectite and mica-group members, phillipsite (a zeolite), and red-brown to yellow-brown semiopaque oxide (RSO) (see Site U1367 smear slides in "Core descriptions"; Fig. F7). The ooze is composed mainly of coccolithophores and RSO, accompanied by foraminifers.

Based on compositional and textural attributes, the sediment at Site U1367 is divided into two lithologic units (Fig. F7). Unit I is metalliferous pelagic clay to metalliferous clay that is divided into Subunits IA and IB based on the vertical distribution of zeolite. Subunit IA contains relatively abundant zeolite, ranging from $14 \%$ to $36 \%$ in smear slides. The modal clay and RSO concentrations increase in Subunit IB as zeolite abundance decreases proportionately. Unit II is nannofossil ooze and nannofossil marl. Unit II is divided into Subunits IIA and IIB based on the vertical distribution of clay and RSO. Concentrations of clay and RSO in Subunit IIA smear slides are $<10 \%$, except for intercalating clay-rich thin layers. Subunit IIB is defined by higher concentrations of clay and RSO.

Lithostratigraphic correlation shows that thickness and composition of units vary among the five holes cored at Site U1367 (Fig. F8). The thickness of Subunit IIA, for example, varies from $5.9 \mathrm{~m}$ in Hole U1367B to $8.7 \mathrm{~m}$ in Hole U1367C. Nonetheless, general composition between different holes is very similar.

\section{Description of units}

\section{Unit I}

\section{Subunit IA}

Intervals: $329-\mathrm{U} 1367 \mathrm{~B}-1 \mathrm{H}-1,0 \mathrm{~cm}$, to $1 \mathrm{H}-3,110$ $\mathrm{cm}$; 329-U1367C-1H-1, $0 \mathrm{~cm}$, to $1 \mathrm{H}-3,30 \mathrm{~cm}$; $329-\mathrm{U} 1367 \mathrm{D}-1 \mathrm{H}-1,0 \mathrm{~cm}$, to $1 \mathrm{H}-4,45 \mathrm{~cm} ; 329$ U1367E-1H-1, $0 \mathrm{~cm}$, to $1 \mathrm{H}-3,120 \mathrm{~cm}$

Depths: Hole U1367B = 0-4.1 mbsf, Hole U1367C $=0-3.3 \mathrm{mbsf}$, Hole U1367D = 0-4.95 mbsf, Hole $\mathrm{U} 1367 \mathrm{E}=0-4.2 \mathrm{~m}$

Lithology: zeolitic metalliferous pelagic clay

All but the lower $\sim 80 \mathrm{~cm}$ of Subunit IA is very dark brown (7.5YR 2.5/2, 2.5/3) (Fig. F9A). The base of the interval corresponds to the base of gradational color change, from very dark brown $(7.5 \mathrm{YR} 3 / 3)$ to dark brown (7.5YR 3/4). The lower limit of this gradational change in Hole U1367B is at interval 329U1367B-1H-3, $110 \mathrm{~cm}$. Similar color change occurs at interval $329-\mathrm{U} 1367 \mathrm{C}-1 \mathrm{H}-3,10-50 \mathrm{~cm}$. In Hole $\mathrm{U} 1367 \mathrm{D}$, the interval containing the lower contact was not recovered because of whole-round sampling before observation. The likely location of the lower contact is interval $329-\mathrm{U} 1367 \mathrm{D}-1 \mathrm{H}-4,45 \mathrm{~cm}$. The lower limit of the color change in Hole U1367E is at interval 329-U1367E-1H-3, $120 \mathrm{~cm}$.

Smear slide analyses identify the major components as clay, RSO, and zeolite (Fig. F7). Their concentra- 
tions fluctuate throughout this subunit, but no clear trends are evident. X-ray diffraction (XRD) analyses of bulk sediment Sample 329-U1367B-1H-2, 70-72 $\mathrm{cm}$, positively identify the zeolite as phillipsite but cannot conclusively resolve the mineralogy of the clay (Fig. F10A). The zeolite crystals observed in smear slides are euhedral and prismatic and have long-axis lengths of 10-100 $\mu \mathrm{m}$ (Fig. F11A). Many of the crystals taken from the sediment/water interface (i.e., the mudline sample) contain fragile penetration twins. RSO grains are rounded to irregularly shaped, range in width from 1 to $80 \mu \mathrm{m}$, and constitute $14 \%$ $-36 \%$ of the sediment. Calcareous nannofossils are recognized at the topmost part of intervals 329U1367B-1H-1, 0-130 cm, and 329-U1367E-1H-1, 0$15 \mathrm{~cm}$, although their abundance is relatively low $(<11 \%)$ and decreases sharply with depth (Fig. F7A). Calcareous microfossils (foraminifers) are rare throughout Subunit IA. See "Paleontology and biostratigraphy" for information regarding their identification and distribution.

Subunit IA sediment consolidation transitions from very poorly consolidated near the mudline to poorly consolidated at the base of the subunit. Moist samples are spongy and sticky.

Most sections are homogeneous and without bedding features. Mottling increases with depth, although the variations in ichnofabric intensity are all within Class 2 (slight bioturbation). Mottling is most evident where heterogeneous components are mixed (e.g., intervals 329-U1367C-1H-3, 18-32 cm, and 329-U1367D-1H-3, 64-90 cm).

\section{Subunit IB}

Intervals: $329-\mathrm{U} 1367 \mathrm{~B}-1 \mathrm{H}-3,110 \mathrm{~cm}$, to $2 \mathrm{H}-1,10$ $\mathrm{cm}$; 329-U1367C-1H-3, $30 \mathrm{~cm}$, to $1 \mathrm{H}-4,110 \mathrm{~cm}$; 329-U1367D-1H-4, $45 \mathrm{~cm}$, to $1 \mathrm{H}-5,114 \mathrm{~cm} ; 329-$ U1367E-1H-3, $120 \mathrm{~cm}$, to $1 \mathrm{H}-5,60 \mathrm{~cm}$

Depths: Hole U1367B $=4.1-5.6$ mbsf, Hole $\mathrm{U} 1367 \mathrm{C}=3.3-5.6 \mathrm{mbsf}$, Hole U1367D $=4.95-$ $7.1 \mathrm{mbsf}$, Hole U1367E $=4.2-6.6 \mathrm{mbsf}$

Lithology: metalliferous pelagic clay to metalliferous clay

The sediment in Subunit IB is dark brown (7.5YR 3/3, 3/4) (Fig. F9B) and very uniform, except for the gradational color change at the boundary between Subunits IA and IB as described above. Although the color change through the lower meter of Subunit IB is gradational, it ends abruptly (within $10 \mathrm{~cm}$ ) above the contact with Unit II. The contact between Subunits IB and IIA is clearly observed in Holes U1367B, U1367D, and U1367E and is not observed in Hole U1367C because of wholeround sampling before observation.
Smear slide analyses indicate an overall abundance of RSO and clay components in Subunit IB (Fig. F11B). Zeolite abundance decreases with increasing depth and comprises 30\% of the sediment at the upper contact. Zeolite is entirely absent from clay overlying the lower contact (Fig. F7A). The sediment in the lowermost part of this subunit contains $<1 \%$ nannofossils. Relatively few whole foraminifers were observed in smear slides. Foraminifers observed in $>63 \mu \mathrm{m}$ sieved samples were fragmented and altered.

The consolidation of Subunit IB is uniformly moderately indurated (firm clay).

Most sections are homogeneous and without bedding features. Burrowing is evident at the transition between Units I and II where heterogeneous components are mixed (e.g., interval 329-U1367E-1H-5, 50$64 \mathrm{~cm})$.

\section{Unit II}

\section{Subunit IIA}

Intervals: $329-\mathrm{U} 1367 \mathrm{~B}-2 \mathrm{H}-1,10 \mathrm{~cm}$, to $2 \mathrm{H}-4,150$ $\mathrm{cm} ; 329-\mathrm{U} 1367 \mathrm{C}-1 \mathrm{H}-4,110 \mathrm{~cm}$, to $2 \mathrm{H}-5,110$ $\mathrm{cm} ; 329-\mathrm{U} 1367 \mathrm{D}-1 \mathrm{H}-5,114 \mathrm{~cm}$, to $2 \mathrm{H}-5,20 \mathrm{~cm}$; $329-\mathrm{U} 1367 \mathrm{E}-1 \mathrm{H}-5,60 \mathrm{~cm}$, to $2 \mathrm{H}-5,150 \mathrm{~cm}$

Depths: Hole U1367B = 5.6-11.5 mbsf, Hole $\mathrm{U} 1367 \mathrm{C}=5.6-14.3 \mathrm{mbsf}$, Hole U1367D = 7.113.6 mbsf, Hole U1367E $=6.6-14.0$ mbsf

\section{Lithology: nannofossil ooze}

Sediment color in Subunit IIA is variable, but it is generally strong brown to pink $(7.5 \mathrm{YR} 5 / 4,5 / 6,6 / 3$, $6 / 4,6 / 6,7 / 3,7 / 4$ ) (Fig. F9C), except for intercalating clay-rich thin layers (brown to dark brown; 7.5YR $3 / 2,3 / 3,3 / 4,4 / 2,5 / 3)$. The color changes gradually at the base of this subunit to brown (7.5YR 5/3). The transition to Subunit IIB is clearly observed in Holes $\mathrm{U} 1367 \mathrm{~B}$ and U1367E and is not observed in Holes U1367C and U1367D because of whole-round sampling before observation.

Smear slide analyses indicate that Subunit IIA is predominantly nannofossil ooze (Fig. F11C). Most intervals consist of $80 \%-95 \%$ coccolithophores and coccolithophorid debris (Fig. F7). Foraminifers are also recognized by smear slide analyses, but their content is generally $<15 \%$ of bulk sediment samples. In two intervals of particularly low clay abundance (intervals 329-U1367B-1H-2, 70-72 cm, and 2H-6, 5$7 \mathrm{~cm}$ ), XRD analyses identified calcite (a: $4.9887 \AA$, c: $17.05290 \AA$ ) as the form of the carbonate (Fig. F10B). The upper middle part of the subunit includes a thick $(20-40 \mathrm{~cm})$ bed of clay containing 10\%-40\% RSO. The clay corresponds to a distinctive uptick in magnetic susceptibility that occurs in Holes U1367B-U1367E. Thin $(5-10 \mathrm{~cm})$ layers with relatively high RSO content are repeatedly intercalated 
throughout this subunit and exhibit distinct color changes (Fig. F9C).

Subunit IIA is poorly consolidated, except for the transitional part to Subunit IIB where RSO content is relatively high. Moist samples of this unit are sticky.

Mottling occurs throughout this subunit. Thin layers reflecting change in nannofossil content and RSO content are also common. Slight to moderate burrowing is evident in intervals $329-\mathrm{U} 1367 \mathrm{~B}-2 \mathrm{H}-2,50$ $100 \mathrm{~cm}$; 329-U1367C-1H-4, 110-130 cm; 329U1367D-2H-2, 110-150 cm; and 329-U1367E-2H-2, $105 \mathrm{~cm}$, to $2 \mathrm{H}-3,100 \mathrm{~cm}$. Several narrow $(3-4 \mathrm{~mm})$ burrows below the thickly bedded clay in the upper middle part of Subunit IIA are particularly noteworthy because they extend as far as $80 \mathrm{~cm}$ into the underlying nannofossil ooze (Fig. F9D).

\section{Subunit IIB}

Intervals: $329-\mathrm{U} 1367 \mathrm{~B}-2 \mathrm{H}-5,0 \mathrm{~cm}$, to $4 \mathrm{H}-1,0-32$ $\mathrm{cm} ; 329-\mathrm{U} 1367 \mathrm{C}-2 \mathrm{H}-5,110 \mathrm{~cm}$, to $4 \mathrm{H}-1,0-9$ $\mathrm{cm}$; 329-U1367D-2H-5, $20 \mathrm{~cm}$, to $3 \mathrm{H}-\mathrm{CC}, 10 \mathrm{~cm}$; 329-U1367E-2H-6, $0 \mathrm{~cm}$, to $3 \mathrm{H}-\mathrm{CC}$ (no recovery; 24.17 mbsf), Hole U1367F (upper contact not cored; lost core at lower contact)

Depths: Hole U1367B = 11.5 to $22.0-22.32 \mathrm{mbsf}$, Hole U1367C $=14.3$ to $26.2-26.29 \mathrm{mbsf}$, Hole $\mathrm{U} 1367 \mathrm{D}=13.6-25.2 \mathrm{mbsf}$, Hole U1367E = 14.0$24.17 \mathrm{~m}$ (estimated), Hole U1367F (upper contact not cored; lost core at lower contact)

Lithology: clay-bearing nannofossil ooze to nannofossil marl

The color of Subunit IIB is variable, reflecting changes in concentrations of nannofossils and RSO (Fig. F7). The overall color of the subunit is dark yellow-brown (10YR 3/4) (Fig. F9E). Generally, the colors become darker in the lower part of the subunit, changing from brown (7.5YR 4/4,5/3) and dark yellow-brown (10YR 3/4) to very dark brown (7.5YR $2.5 / 2$ ). The colors of intercalated layers containing relatively abundant nannofossils are dark yellowish brown (10YR 4/4), brown (7.5YR 4/3, 4/4, 10YR 4/3), and dark brown (7.5YR 3/3), probably reflecting differences in nannofossil content. The lower part of this subunit exhibits strong brown (7.5YR 4/6) to reddish yellow (7.5YR 6/6) colors. A well-indurated layer $(40-120 \mathrm{~cm})$ in the lower quarter of subunit is dark brown (7.5YR 3/3, 3/4, 10YR 4/3), dark yellowish brown (10YR 3/4), and yellow (10YR 7/6) (Fig. F9F).

Smear slide analyses indicate that Subunit IIB contains abundant nannofossil ooze (Fig. F7). Of the 12 slides prepared from samples below Section 329U1367B-5H-5 (11.5 mbsf), 10 consist of $>70 \%$ calcareous nannofossils and nannofossil debris. RSO con- centration is higher than in Subunit IIA (Fig. F11D) and increases with depth in Hole U1367E (Fig. F7B). Numerous foraminifers from Sample 329-U1367B$2 \mathrm{H}$-CC contain micrite on the exterior surfaces of their shells. A diffractogram from XRD analyses of bulk sediment (Sample 329-U1367B-3H-4, 50-52 cm) includes numerous peaks corresponding to calcite (Fig. F10C). Several peaks of much lower intensity in the lower and higher ranges of $2 \theta$ correspond to clay that is most likely smectite.

The upper half of this subunit is poorly consolidated. The lower half is well consolidated. The chalk layer is well indurated.

Subunit IIB contains numerous thin layers $(1-3 \mathrm{~cm})$ and laminations $(<1 \mathrm{~cm})$ that correspond to changing nannofossil and RSO abundances. These bedding features are visible as lighter (nannofossil) and darker (RSO) layers in core photographs (e.g., Fig. F9E). All of the observed layers in Subunit IIB are bioturbated. The bioturbation forms ichnofabric Classes 2-4 that moderately disrupt to thoroughly destroy bedding features (Fig. F9F).

\section{Sediment/Basalt contact}

Components of the sediment/basalt interface were recovered in Holes U1367B-U1367D. Although the steel cutting shoe on the APC core barrel was damaged significantly by hitting hard rock at $24.17 \mathrm{mbsf}$ in Hole U1367E, no sediment was recovered. Rotary drilling in Hole U1367F produced sediment and basalt; however, several meters of core were lost during drilling and the sediment that was recovered was highly disturbed. Therefore, we do not consider those materials to be representative of the sediment/ basalt contact.

The recovered sediment was mixed thoroughly with fragmented basalt and volcanic glass. Continuous sections of interfacial sediment and overlying marl were recovered in Holes U1367B and U1367D. However, the $30-60 \mathrm{~cm}$ of sediment overlying the interface was highly disturbed in both holes. Therefore, the nature of the contacts and structures associated with the sediment/basalt contact at Site U1367 are unknown. We believe, however, that the recovered sediment is representative of the overall composition of the interface, and those results are presented below.

The sediment/basalt interface is dark yellow-brown (10YR 3/4) clay with nannofossils and microfossils. The dark color of the clay corresponds to a high (35\%-40\%) abundance of RSO grains that vary in size from 2 to $\sim 200 \mu \mathrm{m}$. Other components of the very fine sediment fraction include calcareous nannofossils and discoasters. Silt and sand grains ( $>4$ 
and $>63 \mu \mathrm{m}$, respectively) constitute $<10 \%$ of the sediment and consist of RSO, microfossils (foraminifers, fish teeth, and sponge spicules), volcanic glass, and quartz (in order of decreasing abundance). Although planktonic and benthic foraminifers exhibit a large range of preservation (see "Paleontology and biostratigraphy"), most exhibit signs of alteration. Volcanic glass exists as large subangular fragments that are highly angular, translucent, amber, and free of surface pits or alterations. The volcanic components are described in "Igneous lithostratigraphy, petrology, alteration, and structural geology."

\section{Discussion}

\section{Sediment composition and texture}

Smear slide and XRD analyses identify clay, zeolite, $\mathrm{RSO}$, and calcite as the principal components of the clay, ooze, marl, and chalk at Site U1367. Clay and calcite distributions stand in stark contrast to one another and define the two units at Site U1367: Unit I contains RSO and zeolitic clay and Unit II contains nannofossil ooze, marl, and chalk.

Within the broad units outlined above, zeolite distribution and clay-to-carbonate relationships help provide insight into the depositional history of Site U1367. These features are described below.

\section{Zeolite}

Although phillipsite never comprises a majority of the sediment, it exists in equal proportions with clay and RSO throughout the uppermost $4-5 \mathrm{~m}$ of Unit I. Its abundance decreases sharply in the lowermost 1.5 $\mathrm{m}$ of Unit I, and it becomes completely absent in the lowermost $50 \mathrm{~cm}$ of the unit. This distribution could result from differences in sediment composition (Bonatti, 1965; Hay, 1966), sediment accumulation rate (Czyscinski, 1973; Glaccum and Boström, 1976), availability of in situ dissolved silica and potassium (Glaccum and Boström, 1976; Sheppard and Gude, 1970), or the age of the phillipsite crystals (Stonecipher, 1976). Each of these parameters is important for reconstructions of the depositional and diagenetic histories of the sediment. However, additional data (petrologic, geochemical, and chronostratigraphic) are needed before the interstitial water-sediment processes that control phillipsite distribution can be used to more fully define the history of Site U1367.

\section{Carbonate}

Several abrupt clay-to-carbonate transitions occur in all of the Site U1367 holes and carry possibly important depositional or oceanographic implications. For example, the Unit I/II boundary consists of a large- scale compositional change from metalliferous clay (60\% RSO and $40 \%$ clay) to nannofossil ooze ( $>80 \%$ calcite) that spans a distance of only 10-15 cm (see Site U1367 core photographs in "Core descriptions"). Slow sediment accumulation on both sides of the contact is indicated by low but persistent abundance of RSO in both the clay and carbonate units (Heath and Dymond, 1977). The contact is also associated with a distinct community of burrowing organisms that mixed clay and carbonate sediment and fragmented most foraminiferal shells. Micritic overgrowths on the foraminiferal shells imply that postdepositional mineralization occurred in the sediment.

Conditions that might account for the Unit II/I carbonate-to-clay transition include an increase in depth of the carbonate compensation depth (Coxall et al., 2005), variable influx of terrigenous and/or biogenic sediment (Glasby, 1991), or evolution of interstitial water chemistry (e.g., Giambalvo et al., 2002). Each of these phenomena, acting exclusively or in consort, might have produced the transition observed from Unit II to I. However, as was the case with zeolite distribution, more thorough studies of sediment petrology, geochemistry, and chronostratigraphy are needed before the origin and implications of the carbonate to clay-transition at Site U1367 can be defined.

\section{Induration}

Considering the overall thinness of the total sedimentary succession $(<25 \mathrm{~m})$, the high degree of induration in Subunit IIB is impressive. Steel blades and a mallet were needed to extract shipboard sediment samples. One thick $(40-120 \mathrm{~cm})$ interval in the middle of Subunit IIB was sufficiently indurated to earn the distinction of being labeled "chalk" (Figs. F7, F8). The cause of variable induration in the sediment is unknown. However, foraminifers from discrete depth intervals of Subunit IIB show evidence of carbonate diagenesis in the form of recrystallization.

\section{Sedimentary structures}

Two observations regarding the bioturbation of sediment at Site U1367 are worthy of note:

- Every meter of core is burrowed or mottled. Although there is no way of demonstrating that burrowers occupied Site U1367 continuously since the onset of sediment accumulation, those organisms persisted with sufficient frequency to disrupt all vestiges of bedding. Most burrows are not adequately isolated or preserved to facilitate identification. However, several burrows possess vertical traces with branches and resemble highly elongated Chondrites, whereas several others are likely 
Trichichnus ichnofossils (Fig. F9D) (Ekdale and Bromley, 1984). The deepest reaching burrows are $60-80 \mathrm{~cm}$ long (see photographs of Core 329U1367E-2H in "Core descriptions"). Given this depth and the extraordinarily slow sediment accumulation rates (see "Paleontology and biostratigraphy"), burrowers only needed to occupy this site once every 0.5 (Unit II) to 20 (Unit I) m.y. to produce the bioturbated textures observed in Site U1367 cores (see Ekdale et al., 1984).

- Ichnofossil traces imply that interstitial water at Site U1367 was frequently oxygenated. The small, soft-bodied organisms responsible for burrowing sediment in pelagic environments similar to those cored at Site U1367 can subsist on 0.1-1 mg/L dissolved $\mathrm{O}_{2}$ (Ekdale et al., 1984). However, this range of values should be considered conservative for Site U1367 given that a number of the burrowers penetrated the subseafloor nannofossil ooze as deep as $80 \mathrm{~cm}$. Supply of dissolved oxygen to the lower parts of these feeding/resting tubes calls for the overlying bottom water to contain a sufficiently high concentration of dissolved oxygen for the period of time needed to diffuse the oxygen into the interstitial water of the underlying sediment (Savrda and Bottjer, 1989). Although burrowing cannot be used to definitively state that sediment at Site U1367 was continuously oxygenated throughout its history, its association with distinct horizons at all sediment depths leads to the conclusion that aerobic bottom water conditions played a significant role influencing the composition and structure of sediment at Site U1367.

\section{Interhole correlation}

Lithostratigraphic correlation among the five APC holes at Site U1367 shows that differences exist among the units and subunits of Site U1367. Several of the differences are artificially created by coring operations, for example,

- The 20.9-21.9 mbsf interval in Core 329U1367B-3H and the 22.6-25.1 mbsf interval in Core $329-\mathrm{U} 1367 \mathrm{C}-3 \mathrm{H}$ are flow-in and not in situ sediment, and

- Whole-round sampling created a large number of gaps in Holes U1367C and U1367D that masked unit boundaries and some beds.

Despite these challenges, a tentative correlation of lithostratigraphic units among the holes of Site U1367 was created (Fig. F9).

\section{Igneous lithostratigraphy, petrology, alteration, and structural geology}

In Hole U1367F, basement was cored from 20 to 50.5 mbsf (0 to 35.5 meters subbasement [msb]), of which $3.39 \mathrm{~m}$ was recovered (11.2\% recovery).

The recovered basement consists of aphyric to sparsely phyric, cryptocrystalline to microcrystalline fragments with large quench structures, a few of which contain glassy margins and a limited number of in situ pieces of more massive units with some chill margins. These lithologies were divided into two basement units based on changes in lava morphology and texture (Fig. F12). Further detail regarding the definition of igneous units may be found in "Lithostratigraphy, igneous petrology, alteration, and structural geology" in the "Methods" chapter (Expedition 329 Scientists, 2011a).

Several small fragments of basalt were recovered in the core catcher of Hole U1367B. These were not assigned an igneous unit because they are altered to the point of groundmass replacement and they were recovered from a different hole with no continuity to basement material recovered from Hole U1367F.

\section{Lithologic units}

\section{Unit 1 (fractured pillow fragments)}

Fractured pillow fragments occupy $3.4 \mathrm{~m}$ of the recovered core ( $86.4 \%$ by volume) and are the most abundant lithology at Site U1367. Classification was based on the presence of curved chilled margins, glassy rinds, and quenching structures that flank cooling fractures (Fig. F13). Vesicles are rare and entirely filled with secondary minerals (see "Igneous petrology" and "Basement alteration"). Although the features used to distinguish pillow lava (glassy rinds, quench structures, and curved chill margins) are not observed in every fragment, they are present throughout Unit 1. The groundmass is composed of plagioclase, clinopyroxene \pm olivine, and Fe-Ti oxide. Textures observed include subophitic, spinifex, and spherulitic. Plagioclase phenocrysts that are 0.1-0.4 $\mathrm{mm}$ wide are present within the groundmass; however, their rarity $(<0.2 \%$ by volume) classifies the rock as aphyric. Most glass observed in Unit 1 is only very slightly altered, with some minor celadonite and iron oxyhydroxide filling vesicles. Glassy margins range from fresh to slightly altered, but overall alteration in Unit 1 is slight. Small portions of each fragment contain brown and dark gray complex ha- 
los that propagate inward from the fracture and chill margins. These alteration halos are not to be confused with the comparatively large chilled margins, which are dark and have a sharp front when viewed in hand specimen.

\section{Unit 2 (thin flow)}

The thin flow occupies the lowermost $54 \mathrm{~cm}$ of Hole U1367F (13.6\% of the core). Classification was based on the reduction of fractures and joints (leading to the only significant section of recovered in situ core), a lack of curved glassy margins and fractures, and an overall decrease in alteration within the lowermost $54 \mathrm{~cm}$ of Hole U1357F compared to the rest of the recovered material. Unit 2 basalt comprises plagioclase, clinopyroxene \pm olivine, and Fe-Ti oxide with grain sizes that range from cryptocrystalline to microcrystalline. No phenocrysts are present (aphyric), and texturally Unit 2 is predominantly porphyritic to intergranular. However, intersertal, glomeroporphyritic, variolitic, and subophitic textures are also observed. Subvertical planar fractures occur within Unit 2 and they are filled with iron oxyhydroxides and saponite. Alteration in Unit 2 ranges from slight to moderate, and it primarily consists of brown to dark gray alteration halos around the chilled margins and veins.

\section{Igneous petrology}

As described above, the basaltic rocks recovered from Hole U1367F are divided into fractured pillow basalt and thin flows. Four samples that best represent the primary igneous textures and alteration effects were selected for petrographic analyses by thin section (see Site U1367 thin sections in "Core descriptions").

\section{Pillow basalt}

The mineralogy of Unit 1 is typical of seafloor basalt. Primary igneous textures and mineralogical differences within the lava are defined by the rapid nature of cooling, including glassy margins, quench structures, and changes in crystal size. The fragments are cryptocrystalline to glassy. Phenocryst abundance ranges from $0 \%$ to $0.2 \%$ (aphyric). Phenocrysts are composed of blocky to prismatic plagioclase and clinopyroxene crystals that typically range from 0.1 to $0.2 \mathrm{~mm}$ in size. The dominant textural pattern within the quench structures is spinifex to intersertal, which is defined as fine radiating laths of plagioclase. Between the plagioclase laths, the texture ranges from glassy to partially formed microcrysts of pyroxene and opaque minerals. Vesicle content is relatively low, but vesicles occur near the glassy margins and within the chilled, partially crystallized zone.

\section{Thin flow}

Unit 2 is a thin flow and contains plagioclase $(60 \%-$ $67 \%)$, clinopyroxene $(26 \%-35 \%)$, Fe-Ti oxides $(2 \%-$ $5 \%$ ), and rare olivine (approximately $<1 \%$ ). Plagioclase forms small prismatic crystals that are intergrown with anhedral to subhedral clinopyroxene and Fe-Ti oxide (titanomagnetite). The groundmass ranges from cryptocrystalline to microcrystalline, and the most common textures are intersertal to intergranular. Grain size within the flow is homogeneous throughout $90 \%$ of the recovered material, except near chilled margins, where grain size reduces to cryptocrystalline. In Unit 2, a number of curved and irregular quenching structures flank cooling fractures. Within the quench structure, textures range from spinifex to intersertal. Phenocrysts are rare $(<0.1 \%$, aphyric) and composed of lathlike 0.3 $\mathrm{mm}$ long plagioclase. Vesicles were not observed in thin section or hand specimen. This was the only unit in which several pieces were recovered in situ at the base of the hole.

\section{Phenocryst phases Plagioclase}

Plagioclase phenocrysts are rare throughout the basement at Site U1367. Although they comprise $<0.1 \%$ of the fractured pillow lavas and the more massive basaltic unit below, plagioclase is the most abundant phenocryst phase. Plagioclase phenocrysts are euhedral to subhedral with a bladed to prismatic crystal structure. Plagioclase phenocrysts range from 0.1 to $0.4 \mathrm{~mm}$ in length and are typically fresh, with only minor replacement by secondary minerals located within alteration halos. Replacement minerals include clays, saponite, and iron oxyhydroxides that occur along cracks, cleavage planes, and edges of plagioclase crystals (see "Basement alteration").

\section{Pyroxene}

Clinopyroxene phenocrysts are very rare $(<<0.1 \%$ of the recovered core), range from 0.1 to $0.2 \mathrm{~mm}$ in length, and are commonly associated with plagioclase phenocrysts. The clinopyroxene phenocrysts are subhedral with simple basal twinning present throughout. Alteration of clinopyroxene phenocrysts ranges from $0 \%$ to $80 \%$ and documents replacement by secondary clays, saponite, iron oxyhydroxides, and oxides along cracks, cleavage planes, or crystal edges. 


\section{Groundmass}

The basaltic groundmass at Site U1367 is composed of plagioclase and clinopyroxene, with minor accessory $\mathrm{Fe}-\mathrm{Ti}$ oxides, whereas grain size varies from glassy to cryptocrystalline. Plagioclase is the most abundant groundmass crystalline phase, comprising between $58 \%$ and $70 \%$ of the groundmass, and it occurs as microlaths, microlites, or spinifex texture within quench structures. Clinopyroxene comprises $\sim 35 \%$ of the fractured pillow lavas (Unit 1) and $\sim 30 \%$ of the more massive basaltic Unit 2 . It occurs as interstitial growths between plagioclase, microlaths, microlites, and aggregates of fibrous or plumose crystals. Within the quench zones, clinopyroxene crystals are either not present or partially grown between spinifex plagioclase. Olivine was not detected within the groundmass; however, the lack of fresh olivine and the difficulty in identifying olivine pseudomorphs (based on relict crystal structure) may have adversely affected our efforts to determine its presence and estimate its abundance. Mesostasis textures include hyalophitic and intersertal; they are present throughout the recovered basement.

In the thin flow unit at Site U1367 the most common texture is intergranular. Mesostasis texture is typically subject to patchy alteration and is preferentially altered relative to the plagioclase and clinopyroxene groundmass. Almost all patchy alteration observed at Site U1367 is the result of altered mesostasis. Replacement minerals in the groundmass include clay (saponite and celadonite), iron oxyhydroxides, and, rarely, carbonate. Primary magmatic opaques $(<1 \%-4 \%$ by volume of Unit 1$)$ are present in all units. These form small $(<0.2 \mathrm{~mm})$, granular, subhedral crystals of titanomagnetite, which are partially replaced.

\section{Hard rock geochemistry}

Under the same analytical techniques and conditions outlined in "Biogeochemistry" in the "Site U1365" chapter (Expedition 329 Scientists, 2011b), five representative samples of basement were analyzed for major and trace elements by inductively coupled plasma-atomic emission spectroscopy (ICPAES). These samples included relatively fresh basalt groundmass (gray to green) and basalt within chilled margins. Samples were selected to examine the chemistry of primary igneous features and alteration. Although rocks recovered at Site U1367 are relatively fresh, alteration is visible within the quench structures. Two samples were selected from the pale gray interiors to represent the least altered basalt. To avoid unrepresentative analyses of whole rock, all samples were selected, where possible, to avoid veins and fractures. Details of the methods for preparation and analyses are in "Lithostratigraphy, igneous petrology, alteration, and structural geology" in the "Methods" chapter (Expedition 329 Scientists, 2011a). The international standard BCR-2 was analyzed 24 times over 3 runs. The analytical precision and accuracy is reported in Table T2 in the "Methods" chapter (Expedition 329 Scientists, 2011a).

\section{Results}

Major and trace element data and loss on ignition (LOI) for the selected samples are shown in Table T2. For all basaltic samples, the ranges of major element oxides include

$$
\begin{aligned}
& \mathrm{SiO}_{2}=46.8-50.2 \mathrm{wt} \%, \\
& \mathrm{Al}_{2} \mathrm{O}_{3}=12.51-14.6 \mathrm{wt} \%, \\
& \mathrm{Fe}_{2} \mathrm{O}_{3}(\mathrm{~T})=11.8-17.6 \mathrm{wt} \%, \\
& \mathrm{MgO}=5.8-6.3 \mathrm{wt} \%, \\
& \mathrm{Na}_{2} \mathrm{O}=2.3-2.9 \mathrm{wt} \%, \\
& \mathrm{TiO}_{2}=2.3-2.6 \mathrm{wt} \%, \text { and } \\
& \mathrm{K}_{2} \mathrm{O}=0.13-0.93 \mathrm{wt} \% .
\end{aligned}
$$

Trace element ranges and averages include

$$
\begin{aligned}
& \mathrm{Sr}=115-167 \mathrm{ppm}(\text { average }=125 \mathrm{ppm}), \\
& \mathrm{V}=427-473 \mathrm{ppm}(\text { average }=461 \mathrm{ppm}), \text { and } \\
& \mathrm{Zr}=161-181 \mathrm{ppm}(\text { average }=166 \mathrm{ppm}) .
\end{aligned}
$$

For the least altered basalts (three samples), total alkaline $\left(\mathrm{K}_{2} \mathrm{O}+\mathrm{Na}_{2} \mathrm{O}\right)$ content ranges from 3.02 to $3.16 \mathrm{wt} \%$ and $\mathrm{SiO}_{2}$ content ranges from 49 to 50 wt $\% . \mathrm{Al}_{2} \mathrm{O}_{3}$ ranges from 13.2 to $14.6 \mathrm{wt} \%$, and $\mathrm{CaO}$ ranges from 10.1 to $11.3 \mathrm{wt} \%$. Because of the profound uncertainty in the location of these samples within Hole U1367F, no downhole geochemical trends can be inferred. $\mathrm{K}_{2} \mathrm{O} / \mathrm{TiO}_{2}$ at Site U1365 ranges from 0.05 to 0.16 , indicating depleted basaltic compositions. The potential for emplacement of potassium-rich secondary minerals (celadonite and saponite) within portions of the least altered samples imply that true primary $\mathrm{K}_{2} \mathrm{O}$ is even lower.

\section{Basement alteration}

All basement rocks at Site U1367 have been subject to alteration by interaction with seawater. Alteration varies from slight to moderate. However, the majority of recovered basement material at Site U1367 is only very slightly altered. Basement alteration at Site U1367 consists of

- Replacement of mesostasis in the groundmass by secondary minerals,

- Filling of veins and formation of halos by emplacement of secondary minerals, and

- Lining and filling of vesicles.

Rock visibly altered in macroscopic view or thin section constitutes between $2 \%$ and $25 \%$ of individual samples, with most alteration concentrated around veins and chilled margin contacts. Alteration prod- 
ucts include saponite, celadonite, iron oxyhydroxides, quartz, and rare carbonate. No breccia was recovered from Site U1367.

Saponite is present throughout the core. Like the other secondary minerals reported at Site U1367, it contains similar properties to those observed in Site U1365 basement samples (see "Igneous lithostratigraphy, petrology, alteration, and structural geology" in the "Site U1365" chapter [Expedition 329 Scientists, 2011b]). Replacement of the groundmass is usually slight and discontinuous, only replacing mesostasis and a minor portion of the groundmass. In areas of moderate alteration, saponite (green/ brown in hand specimen and thin section) replaces mesostasis and a varying proportion of groundmass crystals. Saponite also frequently fills vesicles and forms monomineralic or polymineralic veins. Celadonite (bright green in thin section) is present as discrete infills of vesicles and replacement of mesostasis throughout the recovered basement and it is often found in conjunction with (or overprinted by) iron oxyhydroxides. Iron oxyhydroxides (red to redbrown) in hand specimen and thin section) are present throughout the core and may typically fill or partially fill veins and commonly form iron oxyhydroxide-dominated halos. Other minor secondary minerals identified in hand specimen and thin section include quartz and rare vein calcite. A detailed analysis of secondary mineral phases at Site U1367 will require postexpedition research.

\section{Vein- and halo-related alteration}

The most visible manifestation of alteration at Site U1367 is vein- and halo-related alteration. Dark gray/brown saponitic and celadonitic background alteration occurs throughout the recovered basement at Site U1367. However, vein-related alteration is also present throughout the site as localized, narrow $(\sim 1 \mathrm{~mm})$ to wide $(\sim 20 \mathrm{~mm})$, brown to dark gray or mixed alteration halos that flank the veins. Alteration halos are often preserved where the vein was not recovered. Veins are typically polymineralic with the principal constituents iron oxyhydroxides, celadonite, and saponite. Quartz is also sometimes present as a minor phase in some veins. Two rare $0.1 \mathrm{~mm}$ thick carbonate veins are present at intervals 329U1367F-2R-3, 24-28 cm, and 6R-1, 129-134 cm.

\section{Halos}

Dark green/black halos are present throughout Site U1367; however, they are most concentrated in Unit 2, flanking veins within the massive basaltic pieces. Dark green/gray halos occur in Unit 1 as $1-5 \mathrm{~mm}$ wide halos around cooling fractures and as a component in mixed halos (Fig. F13). Dark green halos are characterized by celadonite replacing mesostasis material and filling vesicles; however, secondary mineral abundance within these dark halos is low $(\sim 1 \%-$ $5 \%)$. Within the dark green/black halos, iron oxyhydroxide may be present in the form of discontinuous bands or discrete alteration patches. Vein- and vesicle-filling sequences (discussed below) indicate that the saponite phase arrived after celadonite. Within the lowermost section of Unit 2 (interval 329U1367F-6R-1, 114-140 cm), dark gray halos produce unusual mottled fronts that propagate within the rock.

Brown halos occur throughout the recovered core at Site U1367. Unit 1 contains thin (1-2 $\mathrm{mm}$ ) brown halos and occasional more pervasive alteration halos that extend beyond the quenching structures. Brown halos also form a component of the mixed halos, frequently overprinting the dark green/black alteration. Brown halos flank iron oxyhydroxide, saponite, celadonite, and polymineralic veins (e.g., Sample 329U1367F-4R-1, 51-53 cm; Fig. F14). Thin section observations of the brown halos indicate that the dominant secondary mineral filling vesicles and replacing interstitial and glassy material is saponite. Replacement of the groundmass varies from $<0.5 \%$ to $10 \%$. Frequently present within these halos are iron oxyhydroxides, which stain the saponite orange-brown. Iron oxyhydroxide covers between $0.5 \%$ and $2 \%$ of the rock within the brown halos.

Red halos are present in discrete areas near chilled margins and within mixed halos. These halos are dominated by iron oxyhydroxides that replace interstitial zones, fill vesicles, and partially alter the groundmass. Typically, red halos are discontinuous and patchy with diffuse halo fronts. Red halos are 1 to $3 \mathrm{~mm}$ thick and occur flanking celadonite, saponite, and iron oxyhydroxide veins. Iron oxyhydroxide tends to overprint celadonitic (dark green/black halos).

Mixed halos occur near cooling fractures and veins and are the most abundant halo type at Site U1367. Mixed halos are the result of multiple overprinting stages from dark green/black halos, red halos, and green-brown halos. Typically, two halo zones co-occur. However, several samples exhibit the complete sequence of halos. Although halos range in thickness from 2 to $20 \mathrm{~mm}$, most are 2 to $5 \mathrm{~mm}$ thick. The mineralogy of each individual halo within each mixed halo essentially falls into any one of the dark green/black, red, or green-brown halo categories. However, because of overprinting, typically the innermost halo contains mineralogy that relates to two or more alteration phases; therefore, the coloration is mixed. In a number of mixed halos, earlier alteration halos are partially overprinted by later al- 
teration halos that extend well beyond the boundary of the previous halo.

\section{Veins}

A total of 66 veins were identified in the basement cores from Hole U1367F, with an average density of 20 veins/m of recovered core (Table T3). Vein thickness varies from $<0.1$ to $1 \mathrm{~mm}$, although most veins are in the $0.1-0.2 \mathrm{~mm}$ range. Veins observed in basement at Site U1367 exhibit curved, planar, and irregular morphologies. Secondary minerals that fill veins include saponite, celadonite, iron oxyhydroxides, sulfides, and rare carbonate. Silicates and zeolite are also present in discrete quantities. A lack of distinct crosscutting veins and indistinct vein relationships in basement recovered at Site U1367 means that order of emplacement remains speculative. Veins may be monomineralic or polymineralic, with any combination of the major secondary minerals. Veins at Site U1367 are usually flanked by mixed alteration halos that propagate outward from the vein. A summary table of all veins is provided in (Table T3).

Saponite is present in nearly all of the veins (31\% of all vein material) and makes up $0.06 \%$ by volume of the recovered basement. Although saponite is most commonly associated with iron oxyhydroxides, its relationship to this mineral phase remains indistinct. Iron oxyhydroxide makes up $27.3 \%$ of the veins and $0.06 \%$ by volume of the recovered rock. Although iron oxyhydroxide commonly occurs with celadonite and saponite, many veins are exclusively composed of iron oxyhydroxide. Celadonite makes up $9 \%$ by volume of all vein material $(0.03 \%$ of the recovered rock). Celadonite occurs intergrown with iron oxyhydroxide (e.g., Sample 329-U1367F-4R-1, 51-53 cm; Fig. F14) and saponite or on its own in narrow $(0.1 \mathrm{~mm})$ veins. In a similar fashion to the overprinting of celadonite in halos discussed earlier celadonite is overprinted by iron oxyhydroxides and saponite. Secondary silicates occur in $14 \%$ of all veins and $0.03 \%$ of the total recovered basement rock. Although silicates occur with all other secondary phases at Site U1367, the lack of clear evidence for overprinting and crosscutting features implies that the timing of silicate emplacement remains unknown. Secondary sulfide veins are typically monomineralic, planar, and narrow (0.1 $\mathrm{mm}$ wide). However, one example also contains celadonite (Sample 329-U1367F-6R-1, 50-51 cm). Sulfides make up $0.01 \%$ of the core and $3 \%$ of recovered vein material. Carbonate at Site U1367 is rare, since it is observed in only two veins (intervals 329-U1367F-2R-3, $19 \mathrm{~cm}$, and $6 \mathrm{R}-1,52 \mathrm{~cm}$ ).
Only one vein in Unit 2 contained enough material for XRD analysis (see Sample 329-U1367F-6R-1, 88$102 \mathrm{~cm}$, diffractogram in Fig. F15). The major peaks are indicative of an iron-rich mineral, possibly glauconite, celadonite, or nontronite. Slight contamination of plagioclase also appears to give rise to a peak indicative of albite or anorthite. The counts per acquisition on the XRD instrument for this sample are very low, with a maximum peak intensity of 280 . Therefore, any conclusions drawn from this analysis must be treated with caution.

\section{Vesicles}

Vesicles are rare in basement rocks recovered at Site U1367. Saponite and iron oxyhydroxide vesicles in halos and near chilled margins make up $<0.01 \%$ of the recovered rock. Because vesicles were not observed in thin section, their detailed alteration history remains open to further study.

\section{Alteration geochemistry}

Of the five samples selected for basement geochemical analyses, one is from relatively altered basalt (Sample 329-U1367F-4R-1, 21-31 cm; altered basaltic chips from the sediment/basement interface) and one is sourced from a chill margin (Sample 4R-1, 51$53 \mathrm{~cm}$ ). A simple comparison between the average of the least altered background samples and the slightly more altered samples (Fig. F16) indicates increases in $\mathrm{Fe}_{2} \mathrm{O}_{3}{ }^{(\mathrm{T})}, \mathrm{MnO}, \mathrm{K}_{2} \mathrm{O}, \mathrm{Ba}, \mathrm{TiO}_{2}$, and LOI and decreases in $\mathrm{Al}_{2} \mathrm{O}_{3}, \mathrm{Na}_{2} \mathrm{O}, \mathrm{P}_{2} \mathrm{O}_{5}, \mathrm{Cu}$, and Sr. Despite the large apparent changes in iron content and LOI, overall change is relatively small. The increases in $\mathrm{Fe}_{2} \mathrm{O}_{3}{ }^{(\mathrm{T})}$, $\mathrm{MnO}, \mathrm{K}_{2} \mathrm{O}$, and LOI may reflect the incorporation of secondary minerals (saponite, celadonite, and iron oxyhydroxides) that contain $\mathrm{Fe}, \mathrm{K}$, and LOI into the groundmass. Increased $\mathrm{TiO}_{2}$ may be the result of incorporation of secondary Fe-Ti oxides, such as titanomagnetite. Although the chilled-margin sample (Sample 329-U1367F-4R-1, 51-53 cm) is generally similar to the other least altered samples (Fig. F16), it exhibits slightly elevated $\mathrm{Fe}_{2} \mathrm{O}_{3}{ }^{(\mathrm{T})}, \mathrm{MnO}$, and $\mathrm{K}_{2} \mathrm{O}$. These changes indicate slight alteration along the margins, which is supported by the presence of brown alteration halos. Despite the location of Sample 329-U1367F-4R-1, 21-31 cm, at the sediment/ basement interface, $\mathrm{Ca}$ and $\mathrm{Mg}$ show very little variation, implying only minimal $\mathrm{Ca} / \mathrm{Mg}$ exchange with seawater. The lack of a relatively complete section, however, means that true alteration extent and $\mathrm{Ca} /$ Mg exchange at Site U1367 may be much greater. Detailed postexpedition work, including future drill- 
ing, would be required to fully compositionally characterize rock alteration at Site U1367.

\section{Alteration summary}

The style of low-temperature hydrothermal alteration at Site U1367 is similar to the slight alteration observed in the uppermost portion of the oceanic basement at other areas where in situ ocean crust is recovered (e.g., Ocean Drilling Program (ODP) Holes 504B and 1256D and the nearest sites to Site U1365 [DSDP Sites 595/596]) (Shipboard Scientific Party, 1987; Laverne et al., 1996; Teagle et al., 1996; Teagle, Alt, Umino, Miyashita, Banerjee, Wilson, and the Expedition 309/312 Scientists, 2006).

Alteration extent was recorded by visual observation from core descriptions and by natural gamma radiation (NGR) core logging (using NGR-based potassium concentration as a proxy for alteration extent). The visual record and the NGR-based potassium show strong correspondence. NGR measurements indicate greater alteration at the top and bottom portions of the hole, with limited alteration in the rest of the recovered material (see "Physical properties" for a detailed description of NGR).

Secondary minerals celadonite, saponite, iron oxyhydroxide, and pyrite suggest evolution from open circulation (celadonite and iron oxyhydroxides) to a more restricted environment (saponite and pyrite). Because few vein mineral, vesicle, and halo relationships are present in the recovered rock, the timing of secondary mineral emplacement and alteration regimes is not fully known. Celadonite is replaced by iron oxyhydroxides, and saponite halos may overprint iron oxyhydroxide and celadonite. More detailed analyses of the alteration affects at Site U1367 will be required to determine alteration history.

Low recovery of only small basaltic fragments means that the distribution of alteration cannot be placed precisely. Only Cores 329-U1367F-6R and 2R can be placed in situ because of their large oriented core samples (Core 6R) and position at the top of the hole $(2 \mathrm{R})$. Basaltic fragments recovered from Cores $2 \mathrm{R}$ and $6 \mathrm{R}$ are the most altered, as determined by NGR measurement.

The lack of dissolved $\mathrm{Mg}$ in the lowermost sediment and a dearth of carbonate veins may indicate that $\mathrm{Ca} / \mathrm{Mg}$ exchange is limited (see "Biogeochemistry" in the "Site U1365" chapter [Expedition 329 Scientists, 2011b]). However the poor recovery of basement Site U1367 suggests that the recovered section may not be representative of the true extent of alteration. As such, interpretation of the alteration regime at Site U1367 remains speculative.

\section{Structural geology}

Structural features at Site U1367 are mainly composed of synmagmatic to postmagmatic structural features that include curved or irregular fractures, chilled margins, and pillow structure textures (radial fracturing, curved glassy margins, and vesicles). Cooling fracture fills include saponite, celadonite, and iron oxyhydroxides. The majority of these structures are preserved in basaltic fragments that fell from the sides of the hole during drilling; as such, they are not oriented, not in situ, and therefore unsuitable for measuring. Only three intervals of the entire recovered material at Site U1367 were in situ, two of which contained steeply dipping planar joint fractures filled with vein material (saponite, celadonite, and iron oxyhydroxide). One of these intervals exhibited a conjugate vein pair. These measured structural features were described and entered into the IODP Laboratory Information Management System (LIMS) database with DESClogik software application (see "Lithostratigraphy, igneous petrology, alteration, and structural geology" in the "Methods" chapter [Expedition 329 Scientists, 2011a]). Sample 329-U1367F-6R-1, 60-71 cm, contains a conjugate saponite and iron oxyhydroxide vein with a measured dip and dip direction of $40^{\circ} / 004^{\circ}$ and $35^{\circ} \%$ $180^{\circ}$ for each vein in the conjugate pair (measured as $60^{\circ} / 184^{\circ}$ and $65^{\circ} / 000^{\circ}$ when reoriented to true vertical position).

Most of the observed structure at Site U1367 appears to result from cooling and subsequent fracturing by ingress of seawater and precipitation of secondary minerals. The curved and/or irregular fractures are indicative of fractured or brecciated pillow lava. As such, they represent a marked difference from the horizontal flow fractures and veins observed at Site U1365. The vertical fractures within Unit 2 suggest that later tectonic fracturing took place.

\section{Paleontology and biostratigraphy}

At Site U1367, we recovered a $\sim 24 \mathrm{~m}$ thick sequence of clay-bearing nannofossil ooze with foraminifers at the bottom, nannofossil ooze with foraminifers in the middle, and metalliferous pelagic clay at the top spanning from the base of the Oligocene to the present (Fig. F17; see also "Lithostratigraphy"). See the "Appendix" for a list of foraminifer and ostracod taxa.

Five core catcher samples from the base of Cores 329-U1367C-1H (at 7.2 mbsf), 329-U1367B-2H (at $13.42 \mathrm{mbsf}$ ) and $3 \mathrm{H}$ (at $21.9 \mathrm{mbsf}), 329-\mathrm{U} 1367 \mathrm{E}-3 \mathrm{H}$ 
(at $24.3 \mathrm{mbsf}$ ), and 329-U1367C-3H (at $24.9 \mathrm{mbsf}$ ) were examined for paleontological and biostratigraphic purposes using the $>63 \mu \mathrm{m}$ sediment size fraction. The three deeper samples are dominated by planktonic foraminifers, with lesser amounts of benthic foraminifers and ostracods (i.e., Sample 329U1367-2H-CC in Fig. F18). The biogenic component of the fine fraction $(<63 \mu \mathrm{m})$ is dominated by nannofossils (see "Lithostratigraphy"). The preservation of the different calcareous microfossil groups ranges from moderate near the bottom (Sample 329U1367B-3H-CC) to very good in the middle of the sequence (Sample 2H-CC) to poor at the base of Core $329-\mathrm{U} 1367 \mathrm{C}-1 \mathrm{H}$. The good carbonate preservation between $\sim 24$ and 13.4 mbsf may be due to the shallow depth of the Site U1367 seafloor relative to the calcite lysocline in the early Oligocene. The decrease in preservation near the top is probably due to sinking of the aging seafloor relative to the lysocline followed by sinking of the seafloor beneath the calcite compensation depth (CCD) at the transition from carbonate ooze to pelagic clay. This carbonate preservational history is also reflected in the deepwater environment by the relatively high abundance and excellent preservation of the benthic calcareous microfossils.

\section{Planktonic foraminifers}

Biostratigraphic assignments for Site U1367 are derived from planktonic foraminifers. The overall assemblage includes Globigerina euapertura, Globigerina pseudovenezuelana, Subbotina eocaena, Subbotina linaperta, Subbotina gortanii, Globigerina tapurensis, Globigerina praebulloides, Chiloguembelina cubensis, Cassigerinella chipolensis, Cassigerinella sp., Catapsydrax disimilis, Tenuitellinata angustiumbilicata, Tenuitellinata gemma, Paragloborotalia opima nana, Paragloborotalia opima opima, Pseudohastigerina micra, and Pseudohastigerina naguewichiensis (Table T4). These species are characteristic of Oligocene fauna in low and mid-southern latitudes (Bolli et al., 1985; Jenkins, 1985; Leckie et al., 1993; Berggren and Pearson, 2005; Wade et al., 2007, 2011). We noted the highest diversity of Oligocene taxa, 13 species, in Sample 329-U1367B-2H-CC. Although the stratigraphic distribution of some of the species found at Site U1367 extends into the late Eocene, none of the diagnostic late Eocene forms, such as Hantkenina spp., Turborotalia cerroazulensis, and Globigerinatheka spp., were found.

The lowermost samples examined (Table T4) from $\sim 24$ mbsf are inferred to correspond to the boundary between planktonic foraminifer Zones $\mathrm{O} 1$ and $\mathrm{O} 2$ $(\sim 32 \mathrm{Ma})$ based on the last occurrence (LO) of $P$. naguewichiensis and S. eocaena (Berggren et al., 1995;
Wade et al., 2011) and the presence of $P$. micra. The LO of $P$. micra has been established at $\sim 32.2 \mathrm{Ma}$ (Pearson et al., 2006). Sample 329-U1367B-2H-CC (13.4 mbsf) is inferred to correspond to planktonic foraminifer Zones O3/O4 (30.6-29.4 Ma) based on the common occurrence of C. cubensis and Paragloborotalia opima (Pearson et al., 2006; Wade et al., 2011). It was not possible to assign the uppermost sample examined at $\sim 7.2$ mbsf to a biostratigraphic zone because planktonic foraminifers were poorly preserved. Postexpedition shore-based examination will be required to refine the foraminifer biostratigraphy at this site.

\section{Benthic foraminifers}

More than 18 species of benthic foraminifers were observed in the five samples examined from Site U1367. The assemblage was of relatively high diversity (11-16 species) in the upper two samples (Cores 329-U1367B-2H and 329-U1367C-1H) and showed a marked decline (to 3 species) at the bottom of the section. The overall benthic foraminifer assemblage includes Cassidulina subglobosa, Cibicidoides sp., Dentalina ariena, Dentalina sp., Gyroidinoides soldanii, Karreriella chapapotensis, Lagena spp., Lenticulina gibba, Nodosaria spp., Nuttalides umbonifer, Oridorsalis umbonatus, Pleurostomella sp., Siphonodosaria antillea, Siphonodosaria spinata, Textullaria sp., and Vulvulina spinosa. Only K. chapapotensis and Nodosaria sp. are present throughout the entire section (Table T5).

\section{Ostracods}

Sixteen ostracod genera were found in the core catcher samples from Site U1367 (Table T6). Maximum diversity was observed in Sample 329-U1367B2H-CC (13.4 mbsf) and the lowest diversity (two genera) at the shallowest (7.2 mbsf) and deepest ( $>24$ mbsf) parts of the site. Ostracod preservation ranged uniformly with overall abundance, ranging from very good (several articulated specimens present) to moderate (fragmented valves). Ostracods were preliminarily identified to the generic level and consist of genera that have worldwide distribution and are common in Cenozoic deep-sea sediment (Ayress et al., 1997; Dingle and Lord, 1990; Cronin et al., 2002). Sample 329-U1367B-2H-CC mainly contained Krithe, Hemiparacytheridea, Poseidonamicus, Bradleya, Cytheropteron, and Henryhowella. Krithe and Argilloecia were dominant at the base of the sedimentary section, near the sediment/basement interface, whereas Krithe and Henryhowella were the only genera present in the uppermost sample (Table T6).

Krithe and Argilloecia are common genera in the cold, organic-rich deep-sea North Atlantic (Coles et al., 1994; Rodriguez-Lázaro and Cronin, 1999). In con- 
trast, Bradleya and Henryhowella have been found associated with well-oxygenated deep-sea environments (Cronin et al., 1999; Didié and Bauch, 2000; Alvarez Zarikian et al., 2009).

\section{Physical properties}

At Site U1367, physical property measurements were made to provide basic information characterizing lithologic units. After sediment cores reached thermal equilibrium with ambient temperature at $\sim 20^{\circ} \mathrm{C}$, gamma ray attenuation (GRA) density, magnetic susceptibility, and $P$-wave velocity were measured with the Whole-Round Multisensor Logger (WRMSL) on whole-round core sections. After WRMSL scanning, the whole-round sections were logged for NGR. Thermal conductivity was measured using the fullspace method on sediment cores. Discrete $P$-wave measurements were made on split sediment cores using the Section Half Measurement Gantry (SHMG). Moisture and density (MAD) were measured on discrete subsamples collected from the working halves of the split sediment cores. Additional discrete measurements of electrical resistivity were made on the split sediment sections to calculate formation factor. The Section Half Image Logger and Section Half Multisensor Logger (SHMSL) were used to collect images and color spectrometry of the split surfaces of the archive-half cores. Four holes targeted the sedimentary cover, Holes U1367B-U1367E, and are relatively complete. The most complete hole for logging physical properties was Hole U1367B. Hole U1367F targeted basement but contains a few meters of sediment above basement. Sediment holes have not been correlated and offsets exist. Basalt recovered from Hole U1367F consists of pieces too small for WRMSL and NGR logging.

\section{Density and porosity}

Sedimentary bulk density values at Site U1367 were determined from both GRA density measurements on whole cores and mass/volume measurements on discrete samples from the working halves of split cores (see "Physical properties" in the "Methods" chapter [Expedition 329 Scientists, 2011a]). A total of 39 discrete samples were analyzed for MAD, 8 samples from Hole U1367B, 8 samples from Hole U1367C, 10 samples from Hole U1367D, 12 samples from Hole U1367E, and 1 sample from Hole U1367F.

In general, wet bulk density values determined from whole-round GRA measurements and measurements from discrete samples agree well (Fig. F19A). The most conspicuous feature of the bulk density measurements is the relatively abrupt shift from $\sim 1.3$ to
$1.6 \mathrm{~g} / \mathrm{cm}^{3}$ at $\sim 6 \mathrm{mbsf}$. This shift corresponds to a lithologic change between lithologic Units I and II.

Grain density measurements were determined from mass/volume measurements on discrete samples (Fig. 19B). The mean and standard deviation of grain density is 2.8 and $0.2 \mathrm{~g} / \mathrm{cm}^{3}$, respectively. No depthdependent variation is observed.

Porosity measurements (see "Physical properties" in the "Methods" chapter [Expedition 329 Scientists, 2011a]) were determined from mass/volume measurements on discrete samples. Porosity in lithologic Unit I is $>80 \%$ and drops abruptly to $64 \%$ in Unit II. No depth-dependent trend is observed in Unit II. The decrease in porosity is attributed to the diagenetic precipitation of calcite (Hamilton, 1976) (see "Lithostratigraphy").

\section{Magnetic susceptibility}

Volumetric magnetic susceptibilities were measured using the WRMSL and point measurements were made on the SHMSL on all recovered cores from Site U1367. Uncorrected values of magnetic susceptibility are presented for Holes U1367B-U1367E (Fig. F20). The spatial resolution of the WRMSL magnetic susceptibility loop is $\sim 5 \mathrm{~cm}$, and the observed "ringing" in Holes U1367C-U1367E is due to edge effects.

Magnetic susceptibility values show the greatest variability in lithologic Unit I and peak at $\sim 2$ mbsf. These values decrease rapidly to the boundary between Units I and II. Magnetic susceptibility values in Unit II are more consistent than those in Unit I and increase with depth.

\section{Natural gamma radiation}

NGR results are reported in counts per second (cps) (Fig. F21). NGR counting intervals were $\sim 1 \mathrm{~h}$ per whole-core interval for Hole U1367B but decreased to $0.5 \mathrm{~h}$ per whole-core interval for Holes U1367CU1367E. NGR counts are considered reliable. NGR at the tops of all holes is high, indicating that the sediment/water interface was sampled.

In general, NGR counts decrease with depth to $\sim 10$ mbsf but then increase with greater depth. A prominent but local peak is observed at 7 mbsf in Hole U1367B and at 10 mbsf in Hole U1367E. Ringing is more prevalent in cores from Holes U1367C and U1367D because only short core pieces remained after whole-round sampling prior to NGR measurements.

\section{P-wave velocity}

$P$-wave velocity at Site U1367 was determined from measurements on sediment whole cores and mass/ 
volume measurements on discrete samples from the working halves of sediment split cores (see "Physical properties" in the "Methods" chapter [Expedition 329 Scientists, 2011a]). In general, discrete measurements are similar to whole-core measurements (Fig. F22). The mean value is $\sim 1525 \mathrm{~m} / \mathrm{s}$, which is close to the compressional velocity of water (Fig. F22B). In all holes, there is a shift to higher values in lithologic Unit II relative to Unit I. In Holes U1367C-U1367E, the greater apparent scatter is an artifact caused by edge effects as these measurements were made after whole-round sampling for chemistry and microbiology.

\section{Formation factor}

Electrical conductivity was measured on working halves of the split sediment cores from Hole U1367B. Measurements in Hole U1367B were made at a nominal interval of $10 \mathrm{~cm}$. For each measurement, the temperature of the section was also noted. Surface seawater was used as a standard and measured at least twice per section (Table T7), normally prior to making measurements for that section and then around the $75 \mathrm{~cm}$ offset of each section. These measurements were used to compute the drift (Fig. F23). The temperature dependence of electrical conductivity was corrected and all reported measurements correspond to a temperature of $20^{\circ} \mathrm{C}$. Electrical conductivity measurements were transformed to a dimensionless formation factor by dividing the measurements for the drift (Table T8).

Within lithologic Unit I, the formation factor is generally $<2$ and generally increases with depth (Fig. F24). Formation factor values in Unit II are generally offset from those in Unit I and are $>2$. This pattern inversely mimics the difference in observed porosity between the two units (Fig. F19C).

\section{Thermal conductivity}

Thermal conductivity measurements were made on sediment whole-round cores using the needle-probe method. Many of the needle-probe measurements in lithologic Unit I are considered unreliable because temperature-time series of these measurements indicate that the measurements caused fluid to convect within the samples. Convection leads to unreasonably low estimates of thermal conductivity by causing the thermal response to heating to depart from the theoretical prediction. Convection appears to be less of an issue in Unit II, where decreased porosity may be inhibiting convection, but the scatter is large. Thermal conductivity values of material from a piston core collected during the KNOX-02RR site survey cruise indicate a thermal conductivity value of $0.7 \mathrm{~W} /(\mathrm{m} \cdot \mathrm{K})$ for Unit I (R. Harris, unpubl. data) (Fig.
F25). Thermal conductivity values in Unit II are higher than in Unit I but also show increased scatter. The mean and standard deviation of values in Unit II are 1.0 and $0.2 \mathrm{~W} /(\mathrm{m} \cdot \mathrm{K})$, respectively.

\section{Color spectrometry}

Results from color reflectance measurements are pre-

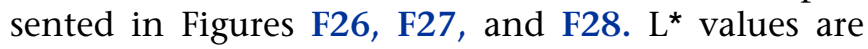
$\sim 35$, with some clusters of higher values at $\sim 275$. The majority of $\mathrm{a}^{*}$ and $\mathrm{b}^{*}$ values are $\sim 5-10$ and $7-19$, respectively. A slight offset in these color reflectance parameters exists between lithologic Units I and II. There is an additional break in $\mathrm{b}^{*}$ values at $\sim 15 \mathrm{mbsf}$. All parameters decrease slightly with depth in Unit II.

\section{Paleomagnetism}

At Site U1367, we measured the natural remanent magnetization (NRM) of all archive-half sections from Holes U1367B-U1367E using the three-axis cryogenic magnetometer at $2.5 \mathrm{~cm}$ intervals before and after demagnetization. The archive-half sections were demagnetized by alternating fields (AF) of 10 and $20 \mathrm{mT}$. The present-day normal field in this region, as expected from the geocentric axial dipole model at Site U1367, has a negative inclination (approximately $-44.9^{\circ}$ ), so positive remanence inclinations indicate reversed polarity. Data from Holes U1367C and U1367D provide only a partial record because whole-round core samples were taken from these holes for geochemical and microbiological analyses. From Hole U1367B, 20 discrete sediment samples $\left(7 \mathrm{~cm}^{3}\right.$ cubes) were taken from the working halves, and compatibility of magnetization between archive and working halves was analyzed. Of these discrete samples, 17 were measured for NRM after demagnetization at peak fields of 10 and $20 \mathrm{mT}$ using the pass-through magnetometer. The primary objective of the shipboard measurements for Site U1367 was to provide chronostratigraphic constraints by determining magnetic polarity stratigraphy. During the coring operation at Site U1367, neither nonmagnetic core barrels nor the Flexit core orientation tool were used because of the shallow drilling depth of the sediment column (see "Operations").

\section{Results}

Paleomagnetic data for Holes U1367B-U1367E are presented in Figures F29, F30, F31, and F32 together with the whole-core susceptibility data measured on the WRMSL. The lithology at Site U1367 changed from metalliferous clay (Unit I) at the top to nannofossil ooze (Unit II) at the bottom (see "Lithostratigraphy"). The metalliferous clay unit extends from 0 
5.5 mbsf in Hole U1367B to 0-8.5 mbsf in Hole U1367E. Consistently, NRM intensities and magnetic susceptibilities in Unit I were $10^{-1}$ to $10^{-2} \mathrm{~A} / \mathrm{m}(>100$ $\times 10^{-5}$ volume SI) and decreased to $\sim 10^{-2}$ to $10^{-3} \mathrm{~A} / \mathrm{m}$ $\left(10 \times 10^{-5}\right.$ to $50 \times 10^{-5}$ volume SI) in Unit II (nannofossil ooze) (Fig. F33). Using magnetic susceptibility data, it was possible to clearly correlate between Holes U1367B and U1367E. This correlation was applied to the magnetic intensity data and to the inclination and declination data (Fig. F34).

Magnetic directions are not clearly interpretable throughout most of the Site U1367 cores, possibly because of a magnetic overprint acquired during coring (high negative inclination), viscous remanent magnetization (VRM), or diagenetic changes in the sediment. However, the carbonate ooze in Unit II in Hole U1367E showed slightly less magnetic overprinting with intervals of reversed polarity recorded (Fig. F34). According to planktonic foraminiferal assemblages, the record at Site U1367 spans from the earliest Oligocene (slightly younger than $34 \mathrm{Ma}$ ) at the sediment/basement interface to $\sim 28 \mathrm{Ma}$ at 13.4 mbsf (see "Paleontology and biostratigraphy"). However, based on the correlation of magnetic susceptibility, the shipboard magnetic polarity record is inconsistent between Holes U1367B and U1367E (Fig. F34) and it is not possible to make any interpretation of the directional data in terms of polarity chrons.

The AF demagnetization record from 12 discrete samples from Hole U1367B deviates slightly from the half-core record (Fig. F29). Magnetic intensities of the discrete samples were lower than those for half cores, and it is likely that the influence of the magnetic overprint is not completely removed from the half-core record.

Given the difficulty in determining the age of the sediment section by shipboard paleomagnetic studies, chronostratigraphy for Site U1367 must be determined by postexpedition studies, including use of other chronostratigraphic tools and further magnetic cleaning by increased AF demagnetization.

\section{Biogeochemistry}

Site U1367 is underlain by 33.5 Ma basaltic basement and has a thinner sediment cover than Sites U1365 and U1366. Onboard measurements and sample processing continued to focus on understanding

- Microbially mediated chemical processes,

- Chemical fluxes between the sediment and the underlying basalt, and

- The potential for radiolysis to support microbial metabolism.
To achieve these objectives, a broad range of chemical species was measured. High-resolution profiles of dissolved oxygen were acquired using optodes and electrodes, headspace samples were taken for hydrogen analyses, and interstitial waters were obtained for analysis using Ti Manheim squeezers and Rhizon pore fluid samplers. Additional sediment samples were taken for solid-phase nitrogen and carbon determination, and separate whole-round intervals were sectioned and squeezed for postexpedition ${ }^{14} \mathrm{C}$ analysis of interstitial waters.

\section{Dissolved oxygen}

Measurements of dissolved oxygen $\left(\mathrm{O}_{2}\right)$ were performed with both optodes and electrodes in Hole U1367B and only with electrodes in Holes U1367C and U1367E and on the first core of Hole U1367F (Tables T9, T10), which was drilled to recover basalt. Dissolved $\mathrm{O}_{2}$ was measured on intact $1.5 \mathrm{~m}$ core sections from Cores 329-U1367B-1H through $3 \mathrm{H}$ and 329-U1367E-1H through 3H. Oxygen electrode measurements were also performed on $20-70 \mathrm{~cm}$ long whole-round sections from Cores 329-U1367C-1H through $3 \mathrm{H}$ after sampling in the ship's core refrigerator on the Hold Deck. For Holes U1367B and U1367E, electrode measurements were typically performed at $15-20 \mathrm{~cm}$ intervals. Electrode measurements were obtained using two individually calibrated electrodes and picoammeter. Optode measurements in Hole U1367B were obtained at 10 $\mathrm{cm}$ intervals for the first meter and $20-50 \mathrm{~cm}$ intervals below $1 \mathrm{~m}$. Below $16 \mathrm{mbsf}$, optode measurements became difficult because of sediment stiffness and were stopped after three optodes were broken in the process of obtaining one data point at $18.8 \mathrm{mbsf}$. Electrode measurements in Hole U1367B were performed to $21.8 \mathrm{mbsf}$ and in Hole U1367E to $24 \mathrm{mbsf}$ in $15-20 \mathrm{~cm}$ intervals. Sections $329-\mathrm{U} 1367 \mathrm{~F}-1 \mathrm{R}-1$ and $1 \mathrm{R}-2$ were also measured using electrodes at 10 cm intervals.

Oxygen measurements in Hole U1367B show that dissolved $\mathrm{O}_{2}$ penetrates from the seafloor to the basalt (Fig. F35A). The steepest decline in $\mathrm{O}_{2}$ content was near the seafloor, with a decrease from $\sim 170$ at the top to $145 \mu \mathrm{M}$ at $3 \mathrm{mbsf}$ for the $\mathrm{O}_{2}$ electrode data and from $\sim 160$ to $135 \mu \mathrm{M}$ at 1 mbsf for the optode data. Values obtained by optode and electrode show the same depth pattern, although the optode-based $\mathrm{O}_{2}$ profile appears smoother. At greater depths, the concentration generally declines in a monotonic manner (Fig. F35). In Hole U1367B, $\mathrm{O}_{2}$ concentrations decline to $\sim 81 \mu \mathrm{M}$ at $21 \mathrm{mbsf}$, just above the basalt interface. The $\mathrm{O}_{2}$ concentration profiles in Holes U1367B and U1367E diverge slightly with 
depth. These differences may partly reflect the depth of the underlying basalt in the two holes, which differ by a few meters despite the short horizontal distance between drilling locations (see "Lithostratigraphy" for differences in basement depths). Dissolved $\mathrm{O}_{2}$ concentrations decrease toward the bottom of all holes, which indicates a net flux of dissolved $\mathrm{O}_{2}$ toward the basement. In Hole U1367B, the $\mathrm{O}_{2}$ gradient may steepen slightly as basement is approached, possibly caused by changes in physical properties (see "Physical properties").

All $\mathrm{O}_{2}$ profiles from the uppermost 10 mbsf exhibit gradients similar to those of the short $(5 \mathrm{~m})$ profile obtained during the site survey cruise ( $\mathrm{D}^{\prime}$ Hondt et al., 2009; Fischer et al., 2009). The $\mathrm{O}_{2}$ profiles at Site U1367 generally match the profiles from Sites U1365 and U1366, except for a shift to lower values caused by a difference in deepwater $\mathrm{O}_{2}$ concentration of $\sim 200 \mu \mathrm{M}$ at Sites U1365 and U1366 and $\sim 170 \mu \mathrm{M}$ at Site U1367 (Talley, 2007).

\section{Dissolved hydrogen and methane}

Dissolved hydrogen $\left(\mathrm{H}_{2}\right)$ concentration was quantified in 48 samples (Table T11). The 38 samples collected from Hole U1367C were taken in the core refrigerator on the Hold Deck. Three of the 10 samples from Hole U1367D (Samples 329-U1367D-3H-3, $135-140 \mathrm{~cm}$; $3 \mathrm{H}-4,135-140 \mathrm{~cm}$; and $3 \mathrm{H}-5,135-140$ $\mathrm{cm}$ ) were taken on the catwalk prior to moving the core sections to the core refrigerator. The sample depths ranged from 0.50 to 24.5 mbsf. Based on the average of 13 blanks, the detection limit (mean plus three times the standard deviation) at this site is 2.2 $n M$. The concentration of $\mathrm{H}_{2}$ remained below the detection limit in the uppermost $4.4 \mathrm{~m}$ of the sediment column (Fig. F36). At greater depths, $\mathrm{H}_{2}$ concentration was often above the detection limit but varied from depth to depth. The maximum concentration of $36 \mathrm{nM}$ was at $9.4 \mathrm{mbsf}$. All three samples collected on the catwalk were below the detection limit (2.2 $\mathrm{nM})$.

Methane concentrations are below the detection limit $(<1.3 \mu \mathrm{M})$ in all samples from Hole U1367B (IODP standard safety protocol). At Site U1367, no samples were taken for the refined protocol. The detection limit is defined here as three times the standard deviation of the blank above the average for the blank (ambient air).

\section{Interstitial water samples}

Interstitial water was extracted from 65 whole-round samples from Holes U1367C and U1366D. We took these samples at a spacing of three per section $(\sim 1$ sample every $50 \mathrm{~cm})$. Nine of the interstitial water whole-round samples were cut and taken on the catwalk and delivered immediately to the Geochemistry Laboratory for squeezing. We extracted water by squeezing for postexpedition ${ }^{14} \mathrm{C}$ analysis from these samples. We obtained 54 Rhizon samples for dissolved nitrate analyses from each of the wholeround samples before squeezing the whole round for further geochemical analysis.

Profiles of dissolved nitrate concentration exhibit good correlation between Holes U1367C and U1367D (Fig. F37A). Nitrate concentration near the seafloor (Sample 329-U1367C-1H-1, 0-10 cm) was $34.97 \mu \mathrm{M}$, similar to concentrations at Sites U1365 and U1366, and increased very slightly with depth to $36.68 \mu \mathrm{M}$ at $1.55 \mathrm{mbsf}$ (Sample 329-U1367C-1H-2, 0-10 cm). Below that depth, nitrate concentration remains relatively constant to $24.45 \mathrm{mbsf}(36.91 \mu \mathrm{M}$; Sample 329-U1367D-3H-6, 0-10 cm). The decreased concentration with depth at Site U1367, as compared to Sites U1365 and U1366, is consistent with diminishment of organic-fueled respiration in subseafloor sediment as marine productivity decreases toward the center of the gyre.

Phosphate concentrations of interstitial water from Holes U1367C and U1367D decrease with increasing depth in the uppermost 10 mbsf (Fig. F37B). Peak phosphate concentration $(2.06 \mu \mathrm{M})$ in the near-surface sediment (0.55 mbsf; Sample 329-U1365C-1H-1, $50-60 \mathrm{~cm})$ is $\sim 0.3 \mu \mathrm{M}$ lower than the concentration expected in the overlying bottom water at this location (Talley, 2007). The pooled standard deviation $(1 \sigma)$ based on three individual measurements of each interstitial water sample is $0.07 \mu \mathrm{M}$ (see "Biogeochemistry" in the "Methods" chapter [Expedition 329 Scientists, 2011a]). The phosphate gradient at Site U1367, in comparison to the previous sites, also appears to be slightly steeper. Below 10 mbsf, phosphate concentrations increase with increasing depth, although considerable scatter in the data is evident. The reasons for the increased variability are not clear. Dissolved silicate concentrations vary between 260 and $300 \mu \mathrm{M}$ throughout the sediment at Site U1367 and exhibit no discernible trend with depth (Fig. F37C). The pooled standard deviation $(1 \sigma)$ based on duplicate measurements of each interstitial water sample is $4 \mu \mathrm{M}$ (see "Biogeochemistry" in the "Methods" chapter [Expedition 329 Scientists, 2011a]). Silica concentrations are similar to concentrations observed at Site U1366.

Alkalinity (Fig. F37D) and dissolved inorganic carbon (DIC) (Fig. F37E) behave similarly with depth in the interstitial water of Site U1367. Alkalinity gradually increases from 2.7 to $3.0 \mathrm{mM}$ in the $0-5 \mathrm{mbsf}$ interval and then sharply decreases to $2.6 \mathrm{mM}$ at 5.5 mbsf (the lithologic transition from metalliferous 
clay to carbonate ooze). From 5 to 25 mbsf, alkalinity appears constant or slightly decreases with depth. Alkalinity of interstitial water samples taken in the core storage refrigerator on the Hold Deck is relatively low compared to alkalinity of the rapidly squeezed ${ }^{14} \mathrm{C}$ samples, which indicates carbonate precipitation in sediment before interstitial water squeezing. Standard deviation and error of alkalinity measurements on standard seawater (CRM94) are 0.064 and $0.015 \mathrm{mM}(N=19)$, respectively.

In the uppermost $5 \mathrm{~m}$ of the sediment column, DIC increases from 2.62 to $2.95 \mathrm{mM}$ (Fig. F37E). Like alkalinity, it then sharply decreases to $2.53 \mathrm{mM}$ at 5.55 mbsf (the lithologic transition from metalliferous clay to carbonate ooze). Below $5.55 \mathrm{mbsf}$, DIC values are between 2.44 and $2.83 \mathrm{mM}$. This scatter could be caused by calcium carbonate precipitation, as suggested by higher DIC values from samples that were squeezed more rapidly. Average standard deviation of triplicate injection of the samples is $0.022 \mathrm{mM}$. The values from Holes U1367C and U1367D are generally consistent.

Sulfate concentrations (Fig. F37F) were determined by ion chromatography. All samples were analyzed in duplicate. Based on the pooled standard deviation of duplicate analyses, the $66 \%$ confidence limit is $0.09 \%$, whereas the sulfate/chloride ratio $66 \%$ confidence limit is $0.05 \%$. Measured sulfate concentrations are less than those of inferred local bottom water $(28.6 \mathrm{mM})$ in the entire section. Between 1.05 and $3.05 \mathrm{mbsf}$, they vary less than $\pm 0.15 \%$ in the sulfate anomaly, although depleted from the seawater ratio by $\sim 5 \%$ (Fig. F37G). From 3.05 mbsf to the bottom of the holes, a larger range varies between 3\% and $8 \%$ depletion. The multiple minima and maxima suggest that variability in the sulfate concentration is dominated by adsorption and desorption during sample recovery and extraction.

Chloride concentrations (Fig. F37H) were determined by ion chromatography. All samples were analyzed in duplicate. Based on the pooled standard deviation of duplicate analyses, the $66 \%$ confidence limit is $0.08 \%$. The sulfate and chloride data from Holes U1367C and U1367D are continuous without offset (Figs. F37F, F37H). Concentrations at the top of the hole are indistinguishable from present-day bottom waters in this region $(554 \mathrm{mM})$. Concentrations generally increase monotonically with depth to $\sim 11$ mbsf. From this depth to the bottom of the holes, chloride varies narrowly $(560 \pm 1 \mathrm{mM})$. This increase is most likely due to relict glacial seawater and possibly hydration of the underlying basement. The increase is approximately one-third of that observed at Sites U1365 and U1366.
At Site U1367, cations were measured using the Dionex ion chromatograph and the Leeman ICP-AES system (Table T12). For the ion chromatography analyses, precision was, as quantified by multiple ( $N$ = 4) triplicate analysis of International Association for the Physical Sciences of the Oceans (IAPSO) standard seawater,

$$
\begin{aligned}
& \mathrm{Ca}=0.96 \% \text { of the measured value, } \\
& \mathrm{Mg}=0.34 \% \text { of the measured value, } \\
& \mathrm{Na}=0.45 \% \text { of the measured value, and } \\
& \mathrm{K}=1.5 \% \text { of the measured value. }
\end{aligned}
$$

The precision of the measurements of cations by ICP-AES was, as quantified by multiple triplicate analyses of IAPSO standard seawater and internal matrix-matched standards,

$\mathrm{Ca}=0.7 \%$ of the measured value,

$\mathrm{Mg}=0.6 \%$ of the measured value,

$\mathrm{Na}=2.2 \%$ of the measured value,

$\mathrm{K}=1 \%$ of the measured value,

$\mathrm{Sr}=0.5 \%$ of the measured value,

$\mathrm{B}=0.7 \%$ of the measured value,

$\mathrm{Fe}=0.5 \%$ of the measured value, and

$\mathrm{Mn}=0.5 \%$ of the measured value.

Accuracy of the ICP-AES results, as quantified by comparison to analysis of IAPSO not included in the calibration, was within precision of the measurement. Concentrations of $\mathrm{Ba}, \mathrm{Fe}$, and $\mathrm{Mn}$ were measured to be at or minimally above their detection limits (both $\sim 1 \mu \mathrm{M}$ ), and thus the data are not tabulated. Slightly elevated Mn concentrations may be in the shallow portion of the sediment column, but this will need to be verified by postcruise analyses.

Profiles of dissolved $\mathrm{Ca}, \mathrm{Mg}$, and $\mathrm{Sr}$ show only slight variation throughout the short depth interval recovered at Site U1367 (Figs. F37I, F37J, F37M). Ca values start near typical seawater $(10.5 \mathrm{mM})$ and show some local minima and maxima in samples gathered in the hold-level core refrigerator and the samples gathered on the catwalk. Dissolved Mg concentrations may slightly decrease with increasing depth, perhaps reflecting slight $\mathrm{Mg}$ uptake into the underlying basalt. Higher precision shore-based analyses will determine whether this weak trend is real or not. As with $\mathrm{Ca}$, concentrations of Sr appear constant with depth.

The profile of $\mathrm{K}$ concentration (Fig. F37K) shows a pattern of slight increases and decreases similar to the Ca profile, although the local minima/maxima are at different depths. The $\mathrm{K}$ profile most significantly presents a local minima at $\sim 11 \mathrm{mbsf}$, when plotted on a scale that shows it. This decrease is also observed in the profile of dissolved B (Table T12), and both decreases suggest the presence of clay alteration reactions through that depth range. Both ion chromatography and ICP-AES data sets are in excel- 
lent agreement in terms of trends and absolute values. Because of Dionex ion chromatograph calibration difficulties, ion chromatography values for $\mathrm{K}$ were only recorded for the uppermost $11 \mathrm{~m}$ of this profile.

\section{Solid-phase carbon and nitrogen}

Concentrations of total carbon, total organic carbon (TOC), total inorganic carbon (TIC), and total nitrogen were determined for 20 samples from Hole U1367B (Fig. F38; Table T13).

Total nitrogen decreases from $0.029 \mathrm{wt} \%$ at the seafloor to below the detection limit at 6.98 mbsf. TOC rapidly decreases from $0.17 \mathrm{wt} \%$ at the seafloor to $0.02 \mathrm{wt} \%$ at $6.98 \mathrm{mbsf}$, remaining low thereafter. Total carbon decreases in the first $45 \mathrm{~cm}$ below seafloor from 2.79 to $0.19 \mathrm{wt} \%$. It then varies around 0.15 $\mathrm{wt} \%$ to $5 \mathrm{mbsf}$, where it shows a dramatic increase to values between 9.19 and $11.16 \mathrm{wt} \%$ in the carbonate ooze between $5 \mathrm{mbsf}$ and basement. The combined total nitrogen and TOC data suggest that the microbially degradable pool of organic matter disappears within the uppermost $7 \mathrm{~m}$ of sediment. The surface remineralization of this pool is also consistent with the steeper oxygen concentration gradients in the surface sediments. TOC below this depth may consist mostly of black carbon that does not undergo aerobic remineralization.

Carbonate values obtained by coulometry follow the same pattern as the TC content obtained from the CHNS elemental analyzer. $\mathrm{CaCO}_{3}$ content decreases from $21.04 \mathrm{wt} \%$ at the seafloor to $0.8 \mathrm{wt} \%$ at 0.45 mbsf. $\mathrm{CaCO}_{3}$ content then varies around $1 \mathrm{wt} \%$ to 5 mbsf, where it increases to values between 79 and 94.6 wt $\%$ until basement.

\section{Microbiology}

Sediment samples for microbiological studies were obtained by APC, primarily from Holes U1367C and U1367D. Basalt core samples were collected from Holes U1367D and U1367F. During APC coring, sample contamination was monitored by PFT injection into the drilling fluid. Samples for sedimentary cell abundance were taken from the cut cores facing interstitial water whole-round cores. After core recovery on the catwalk, core sections were immediately transferred to the core refrigerator on the Hold Deck and subsampled. The temperature of the core refrigerator ranged from $7^{\circ}-10^{\circ} \mathrm{C}$. Microbiological wholeround cores were generally taken at a high depth resolution from the uppermost cores (329-U1367C-1H and $329-\mathrm{U} 1367 \mathrm{D}-1 \mathrm{H})$, as well as the cores just above the sediment/basalt interface (Cores 329-U1367C-4H and 329-U1367D-4H). Because the lowermost cores from Holes U1367C and U1367E were less disturbed, oxygen measurements were taken from these samples prior to subsampling for microbiology (see "Biogeochemistry"). This required the core sections to be equilibrated to the temperature of the cold room prior to sampling.

\section{Cell abundance}

Microbial cells were enumerated by direct counting using epifluorescence microscopy (see "Microbiology" in the "Methods" chapter [Expedition 329 Scientists, 2011a]). Sediment subcores $\left(2 \mathrm{~cm}^{3}\right)$ were taken by tip-cut syringes from Holes U1367C and U1367D for shipboard analysis; for shore-based analysis $10 \mathrm{~cm}$ whole-round cores were taken from Hole $\mathrm{U} 1367 \mathrm{D}$ and frozen at $-80^{\circ} \mathrm{C}$. Fifty-one $2 \mathrm{~cm}^{3}$ syringe samples (Table T14) and 8 whole-round cores (Sections 329-U1367D-1H-1, 1H-2, 1H-4, 2H-1, 2H-3, $2 \mathrm{H}-5,3 \mathrm{H}-1$, and $2 \mathrm{H}-4$ ) were taken from Site U1367.

Four blanks were prepared and counted during processing of the samples from Site U1367, resulting in a mean blank of $4.1 \times 10^{2}$ cells $/ \mathrm{cm}^{3}$ with a standard deviation of $2.3 \times 10^{2}$ cells $/ \mathrm{cm}^{3}$. The minimum detection limit (MDL; blank plus three times standard deviation) was calculated to be $1.1 \times 10^{3} \mathrm{cells} / \mathrm{cm}^{3}$. As the blanks did not vary much between sites, all data were pooled. At the end of the expedition, a single MDL for all sites $\left(1.4 \times 10^{3}\right.$ cells $\left./ \mathrm{cm}^{3}\right)$ was calculated based on the extended database.

Cell abundance in the uppermost sample (329U1367C-1H-1, 10-20 cm; 0.1 mbsf) was $~ 10^{5}$ cells $/ \mathrm{cm}^{3}$. Abundance decreased sharply to $10^{3}$ cells $/ \mathrm{cm}^{3}$ at 3.6 mbsf (Sample 1H-3, 60-70 cm). Below 3.6 mbsf, direct counts did not show any clear trend with depth and were mostly below the detection limit, with a few single replicates exhibiting values slightly more than $10^{3}$ cells $/ \mathrm{cm}^{3}$ (Fig. F39; Table T14).

Basalt samples were collected from the sediment/basalt interface (Section 329-U1367D-3H-CC) and the underlying basalt (Sections 329-U1367F-4R-1 and $6 \mathrm{R}-1)$. The whole-round core from Section 4R-1 was unaltered with no visible veins, whereas many veins associated with yellow, red, or green vein-filling material were in the whole-round core from Section 329-U1367D-6R-1 (for details, see "Lithostratigraphy"). The vein-bearing whole-round core from Section 6R-1 was manually fragmented across the vein during subsampling. A small basalt piece was collected from Section 329-U10367D-3H-CC and cleaned by washing and flaming before being crushed. Cell numbers for basaltic rock samples were directly counted without cell separation (see "Microbiology" in the "Methods" chapter [Expedition 329 
Scientists, 2011a]). Table T15 contains cell count data for the basaltic samples. Although no SYBRstainable cells were observed in the unaltered basement basalt (Section 329-U1367F-4R-1), the cell count of the vein-bearing basalt (Section 6R-1) is 3.9 $\times 10^{4}$ cells $/ \mathrm{cm}^{3}$. The cell number is higher $\left(1.7 \times 10^{5}\right.$ cells $/ \mathrm{cm}^{3}$ ) in basalt pieces composed mainly of veins. However, particulate tracer (fluorescent microsphere) counts indicate that the vein was contaminated during coring or sample handling (see "Contamination assessment"). The interface basalt sample in Hole U1367D contains a relatively high number of cells, $1.1 \times 10^{5}$ cells $/ \mathrm{cm}^{3}$, which is above our MDL $(4.9 \times$ $10^{4}$ cells $/ \mathrm{cm}^{3}$ ) for basalt. The SYBR-stainable cells in the basement and interface basalts will be carefully inspected by shore-based molecular biological and biomineralogical analyses in order to determine if they are distinguishable from contaminants.

\section{Virus abundance}

Unlike previous sites, most of the sediment column at Site U1367 contains abundant carbonate. Therefore, prior to extraction of virus-like particles (VLP), carbonate was dissolved to reduce background fluorescence during counting. Sodium acetate buffer (0.47 M, pH 4.7) was used instead of water during the extraction process. The carbonate was dissolved by gently shaking the buffered slurries for a few minutes. Further extraction of VLPs followed the protocol described in "Microbiology" in the "Methods" chapter (Expedition 329 Scientists, 2011a). Samples 329-U1367D-1H-1, 0-10 cm, and 120-130 cm, and Sections $2 \mathrm{H}-2,3 \mathrm{H}-1$, and 3H-5 (Table T16) were used for shipboard counting of VLPs. Additional samples were preserved at $-80^{\circ} \mathrm{C}$ for shore-based analysis.

For the uppermost sample (329-U1367D-1H-1, 0-10 $\mathrm{cm}), 7.0 \times 10^{5} \mathrm{VLP} / \mathrm{cm}^{3}$ was identified. VLP abundance decreased rapidly within the upper meter of the sediment column (Fig. F40). Ship movement during transit prevented virus enumeration in samples from deeper horizons (Sections $2 \mathrm{H}-2,3 \mathrm{H}-1$, and 3H-5).

\section{Cultivation}

\section{Sediment samples}

Multiple cultivations were initiated onboard using a variety of media for heterotrophic (both aerobic and anaerobic) and autotrophic microorganisms. The whole-round cores were subsampled aseptically with tip-cut syringes to make slurries for inoculation in liquid or on solid media (Table T17). Additional samples were stored in $\mathrm{N}_{2}$-flushed serum bottles or in syringes packed in sterile foil packs stored at $4^{\circ} \mathrm{C}$ for future cultivation experiments (referred to as SLURRY in Table T17). For future cultivation efforts, filtered bottom seawater was transferred to sterile $50 \mathrm{~mL}$ serum bottles, sparged for 5 min with $\mathrm{N}_{2}$, and capped with rubber stoppers and aluminum crimp caps. The bottles were stored at $4^{\circ} \mathrm{C}$ for preparing liquid media on shore.

\section{Seawater control sample}

A surface seawater sample was collected from Site U1367 with a sterile $500 \mathrm{~mL}$ glass bottle immediately after the JOIDES Resolution arrived at the site. Aerobic heterotrophic bacteria were cultured on marine agar (MA) and marine R2A (MR2A) plates at $25^{\circ} \mathrm{C}$ for 1 week. The abundance of cultivable aerobic heterotrophic bacteria on MA and MR2A were $\sim 30$ and $~ 16.5$ colony-forming units (cfu)/mL, respectively. Twentyseven isolates were subcultured and stored at $-80^{\circ} \mathrm{C}$ in $20 \%$ glycerol and will be identified by $16 \mathrm{~S}$ rRNA gene sequencing on shore to serve as a contamination control in the future.

\section{Molecular analyses}

\section{Sediment samples}

Whole-round cores were taken throughout the entire sediment column and transferred to $-80^{\circ} \mathrm{C}$ freezers for storage. These samples will be used to determine microbial community composition and the presence or absence of functional genes. Eight $10 \mathrm{~cm}$ wholeround cores were taken as routine microbiology samples (RMS; curatorial code MBIO) for storage at $-80^{\circ} \mathrm{C}$ at the core repositories for future biological sample requests.

\section{Deep seawater control sample}

As a control sample for shore-based molecular analysis, $300 \mathrm{~mL}$ of bottom seawater was collected from Core $329-\mathrm{U} 1367 \mathrm{D}-1 \mathrm{H}$ in a sterilized plastic bag and immediately stored at $4^{\circ} \mathrm{C}$ in the Microbiology Laboratory. The bottom water sample was then filtered through $0.2 \mu \mathrm{m}$ polycarbonate membrane filters under aseptic conditions and stored at $-80^{\circ} \mathrm{C}$ for shorebased microbiological analyses.

\section{Basalt samples}

Samples of basement basalt (Sections 329-U1367F$4 \mathrm{R}-1$ and $6 \mathrm{R}-1$ ), as well as sediment, basalt, and alteration material from the sediment/basalt interface (Cores 329-U1367D-3H and $4 \mathrm{H}$ ) were stored at $-80^{\circ} \mathrm{C}$. Before being frozen, each basalt piece was washed at least twice with $3 \% \mathrm{NaCl}$ solution, flamed, and crushed into powder (see "Microbiology" in the "Methods" chapter [Expedition 329 Scientists, 2011a]). Some portions of these powdered samples were incubated at $4^{\circ} \mathrm{C}$ in RNAlater solution 
overnight and then frozen at $-80^{\circ} \mathrm{C}$ for shore-based DNA and RNA analyses.

\section{Fluorescence in situ hybridization analysis}

Duplicate $10 \mathrm{~cm}^{3}$ subcores of sediment from Sections 329-U1367F-1H-1, 1H-2, 2H-2, 3H-1, and 3H-5 were fixed as described in "Microbiology" in the "Methods" chapter (Expedition 329 Scientists, 2011a) for shore-based fluorescence in situ hybridization analyses.

\section{Radioactive and stable isotope tracer incubation experiments}

Stable isotope $\left({ }^{13} \mathrm{C}\right.$ and $\left.{ }^{15} \mathrm{~N}\right)$ experiments to measure carbon and nitrogen uptake activities were initiated on board in the Isotope Isolation Van. Sediment subcores $\left(15 \mathrm{~cm}^{3}\right)$ were taken from the inner part of 20 $\mathrm{cm}$ whole-round cores, placed in a sterile glass vials, flushed with $\mathrm{N}_{2}$, sealed with a rubber stopper, and stored until processing in the core refrigerator on the Hold Deck (see "Microbiology" in the "Methods" chapter [Expedition 329 Scientists, 2011a]). From Site U1367, five whole-round cores (i.e., Sections 329-U1367D-1H-2, 2H-1, 2H-6, 3H-2, and 3H-6) were processed for incubation experiments, as described in "Microbiology" in the "Site U1365" chapter (Expedition 329 Scientists, 2011b).

The following whole-round intervals from Site U1367 were used for sediment slurry experiments on potential metabolic activities (i.e., assimilation and dissimilative respiration) using radio- and stable isotopes: Samples 329-U1367C-1H-2, 90-80 cm; 1H-5, 70-80 cm; and 3H-3, 80-90 cm (see "Microbiology" in the "Methods" chapter [Expedition 329 Scientists, 2011a]). These incubation slurry samples from Sites U1367 were processed together with other samples from Sites U1365, U1366, and U1368 in the Isotope Isolation Van.

Samples of basement basalt (Sections 329-U1367F4R-1 and 6R-1) as well as sediment, basalt, and alteration material from the sediment/basalt interface (Cores $329-\mathrm{U} 1367 \mathrm{D}-3 \mathrm{H}$ and $4 \mathrm{H}$ ) were stored at $4^{\circ} \mathrm{C}$. Incubations of the sediment/basalt interface samples with ${ }^{15} \mathrm{~N}$-labeled $\mathrm{NO}_{3}{ }^{-}$as a nitrogen source and ${ }^{13} \mathrm{C}$ labeled $\mathrm{HCO}_{3}{ }^{-}$or acetate as a carbon source were initiated onboard.

\section{Contamination assessment}

\section{Perfluorocarbon tracer}

We used perfluoromethylcyclohexane as PFT to monitor the level of drilling fluid contamination in sediment cores. PFT was continuously injected into drilling fluids during APC coring in Holes U1367C and U1367D. Subcore sediment samples $\left(3 \mathrm{~cm}^{3}\right)$ were taken from the catwalk and from whole-round cores in the cold room and stored in vials with $2 \mathrm{~mL}$ of water for postexpedition gas chromatography measurement (see "Microbiology" in the "Methods" chapter [Expedition 329 Scientists, 2011a]).

\section{Particulate tracer}

Fluorescent microspheres ( $0.5 \mu \mathrm{m}$ in diameter) were used for contamination testing during basaltic basement coring (see "Microbiology" in the "Methods" chapter [Expedition 329 Scientists, 2011a]). This approach is not quantitative but does provide evidence for the occurrence of contamination, even in interior structures of basaltic samples (e.g., microfractures, veins). For detection of microspheres, small rock pieces and/or surface wash solutions were stored in $3 \% \mathrm{NaCl}$ solution prior to microscopic examination.

Contamination was first examined on the untreated exterior by removing small pieces of rock using a flame-sterilized hammer and chisel. The rock surface was washed twice with $25 \mathrm{~mL}$ of a $3 \% \mathrm{NaCl}$ solution in a sterile plastic bag. Small pieces of the washed exterior were removed using a flame-sterilized hammer and chisel, and wash solutions were pooled in a 50 $\mathrm{mL}$ centrifuge tube. After the washing step, the rock surface was flamed with a propane torch for a few seconds. The flamed rock was cracked open using a flame-sterilized hammer and chisel, and small pieces from the interior and exterior were separately inspected for the occurrence of microspheres using a fluorescence microscope.

Results from microscopic counting of microspheres in subsamples from each cleaning step are shown in Figure F40 and Table T15. The unit in the figure is either per cubic centimeter of rock for removed basalt pieces or per cubic centimeter post surface-wash solution. Two basalt sections (329-U1367F-4R-1 and 6R-1) were associated with high numbers of microspheres. Even after the cleaning steps, microspheres were detected in the interior of the vein-bearing core from Section 6R-1. However, no microspheres were detected in the interior of the unaltered core from Section 6R-1. The results from microscopic counting of microspheres in Hole U1365E are also shown for comparison. (Fig. F40) The basalt cores with hard vein material in Hole U1365E were not intruded with microspheres during drilling and laboratory cleaning. Therefore, it is likely that veins filled with soft materials are more susceptible to drilling contamination than those filled with hard materials. 


\section{References}

Alvarez Zarikian, C.A., Stepanova, A.Y., and Grützner, J., 2009. Glacial-interglacial variability in deep sea ostracod assemblage composition at IODP Site U1314 in the subpolar North Atlantic. Mar. Geol., 258(1-4):69-87. doi:10.1016/j.margeo.2008.11.009

Ayress, M., Neil, H., Passlow, V., and Swanson, K., 1997. Benthonic ostracods and deep watermasses: a qualitative comparison of southwest Pacific, Southern and Atlantic Oceans. Palaeogeogr., Palaeoclimatol., Palaeoecol., 131(34):287-302. doi:10.1016/S0031-0182(97)00007-2

Berggren, W.A., Kent, D.V., Swisher, C.C., III, and Aubry, M.-P., 1995. A revised Cenozoic geochronology and chronostratigraphy. In Berggren, W.A., Kent, D.V., Aubry, M.-P., and Hardenbol, J. (Eds.), Geochronology, Time Scales and Global Stratigraphic Correlation. Spec. Publ._SEPM (Soc. Sediment. Geol.), 54:129-212.

Berggren, W.A., and Pearson, P.N., 2005. A revised tropical to subtropical Paleogene planktonic foraminiferal zonation. J. Foraminiferal Res., 35(4):279-298. doi:10.2113/ 35.4.279

Bolli, H.M., and Saunders, J.B., 1985. Oligocene to Holocene low latitude planktic foraminifera. In Bolli, H.M., Saunders, J.B., and Perch-Nielsen, K. (Eds.), Plankton Stratigraphy (Vol. 1): Planktic Foraminifera, Calcareous Nannofossils and Calpionellids: Cambridge (Cambridge Univ. Press), 155-262.

Bonatti, E., 1965. Palagonite, hyaloclastites and alteration of volcanic glass in the ocean. Bull. Volcanol., 28(1):257269. doi:10.1007/BF02596930

Coles, G.P., Whatley, R.C., and Moguilevsky, A., 1994. The ostracod genus Krithe from the Tertiary and Quarternary of the North Atlantic. Palaeontology, 37(1):71-120.

Coxall, H.K., Wilson, P.A., Pälike, H., Lear, C.H., and Backman, J., 2005. Rapid stepwise onset of Antarctic glaciation and deeper calcite compensation in the Pacific Ocean. Nature (London, U. K.), 433(7021):53-57. doi:10.1038/nature03135

Cronin, T.M., DeMartino, D.M., Dwyer, G.S., and Rodriguez-Lazaro, J., 1999. Deep-sea ostracode species diversity: response to late Quaternary climate change. Mar. Micropaleontol., 37(3-4): 231-249. doi:10.1016/S03778398(99)00026-2

Cronin, T.M., Boomer, I., Dwyer, G.S., and RodriguezLázaro, J., 2002. Ostracoda and paleoceanography. In Holmes, J.A., and Chivas, A.R. (Eds.), The Ostracoda: Applications in Quaternary Research: Washington, DC (Am. Geophys. Union), 99-119.

Czyscinski, K., 1973. Authigenic phillipsite formation rates in the central Indian Ocean and the Equatorial Pacific Ocean. Deep-Sea Res. Oceanogr. Abstr., 20(6):555-559. doi:10.1016/0011-7471(73)90079-X

Didié, C., and Bauch, H.A., 2000. Species composition and glacial-interglacial variations in the ostracode fauna of the northeast Atlantic during the past 200,000 years. Mar. Micropaleontol., 40(1-2):105-129. doi:10.1016/ S0377-8398(00)00034-7

Dingle, R.V., and Lord, A.R., 1990. Benthic ostracods and deep water-masses in the Atlantic Ocean. Palaeogeogr.,
Palaeoclimatol., Palaeoecol., 80(3-4):213-235. doi:10.1016/0031-0182(90)90133-R

D’Hondt, S., Abrams, L.J., Anderson, R., Dorrance, J., Durbin, A., Ellett, L., Ferdelman, T., Fischer, J., Forschner, S., Fuldauer, R., Goldstein, H., Graham, D., Griffith, W., Halm, H., Harris, R., Harrison, B., Hasiuk, F., Horn, G., Kallmeyer, J., Lever, M., Meyer, J., Morse, L., Moser, C., Murphy, B., Nordhausen, A., Parry, L., Pockalny, R., Puschell, A., Rogers, J., Schrum, H., Smith, D.C., Soffientino, B., Spivack, A.J., Stancin, A., Steinman, M., and Walczak, P., 2011. KNOX-02RR: drilling site survey-life in subseafloor sediments of the South Pacific Gyre. In D'Hondt, S., Inagaki, F., Alvarez Zarikian, C.A., and the Expedition 329 Scientists, Proc. IODP, 329: Tokyo (Integrated Ocean Drilling Program Management International, Inc.). doi:10.2204/ iodp.proc.329.112.2011

D’Hondt, S., Spivack, A.J., Pockalny, R., Ferdelman, T.G., Fischer, J.P., Kallmeyer, J., Abrams, L.J., Smith, D.C., Graham, D., Hasiuk, F., Schrum, H., and Stancine, A.M., 2009. Subseafloor sedimentary life in the South Pacific Gyre. Proc. Natl. Acad. Sci. U. S. A., 106(28):1165111656. doi:10.1073/pnas.0811793106

Ekdale, A.A., and Bromley, R.G., 1984. Comparative ichnology of shelf-sea and deep-sea chalk. J. Paleontol., 58(2):322-332.

Ekdale, A.A., Bromley, R.G., and Pemberton, S.G. (Eds.), 1984. Ichnology: The Use of Trace Fossils in Sedimentology and Stratigraphy. SEPM Short Course, 15.

Expedition 329 Scientists, 2011a. Methods. In D'Hondt, S., Inagaki, F., Alvarez Zarikian, C.A., and the Expedition 329 Scientists, Proc. IODP, 329: Tokyo (Integrated Ocean Drilling Program Management International, Inc.). doi:10.2204/iodp.proc.329.102.2011

Expedition 329 Scientists, 2011b. Site U1365. In D'Hondt, S., Inagaki, F., Alvarez Zarikian, C.A., and the Expedition 329 Scientists, Proc. IODP, 329: Tokyo (Integrated Ocean Drilling Program Management International, Inc.). doi:10.2204/iodp.proc.329.103.2011

Fischer, J.P., Ferdelman, T.G., D'Hondt, S., Røy, H., and Wenzhöfer, F., 2009. Oxygen penetration deep into the sediment of the South Pacific gyre. Biogeosciences, 6(8):1467-1478. doi:10.5194/bg-6-1467-2009

Giambalvo, E.R., Steefel, C.I., Fisher, A.T., Rosenberg, N.D., and Wheat, C.G., 2002. Effect of fluid-sediment reaction on hydrothermal fluxes of major elements, eastern flank of the Juan de Fuca Ridge. Geochim. Cosmochim. Acta, 66(10):1739-1757. doi:10.1016/S00167037(01)00878-X

Glaccum, R., and Boström, K., 1976. (Na, K)-phillipsite: its stability conditions and geochemical role in the deep sea. Mar. Geol., 21(1):47-58. doi:10.1016/00253227(76)90103-1

Glasby, G.P., 1991. Mineralogy, geochemistry, and origin of Pacific red clays: a review. N. Z. J. Geol. Geophys., 34(2):167-176. doi:10.1080/00288306.1991.9514454

Gradstein, F.M., Ogg, J.G., and Smith, A. (Eds.), 2004. A Geologic Time Scale 2004: Cambridge (Cambridge Univ. Press). http://cambridge.org/uk/catalogue/catalogue.asp?isbn=9780521781428 
Hamilton, E.L., 1976. Variations of density and porosity with depth in deep-sea sediments. J. Sediment. Res., 46(2):280-300. doi:10.1306/212F6F3C-2B24-11D78648000102C1865D

Hay, R.L., 1966. Zeolites and zeolitic reaction in sedimentary rocks. Spec. Pap.-Geol. Soc. Am., 85.

Heath, G.R., and Dymond, J., 1977. Genesis and transformation of metalliferous sediments from the East Pacific Rise, Bauer Deep, and Central Basin, Northwest Nazca Plate. Geol. Soc. Am. Bull., 88(5):723-733. doi:10.1130/ 0016-7606(1977)88<723:GATOMS>2.0.CO;2

Jenkins, D.G., 1985. Southern mid-latitude Paleocene to Holocene planktic foraminifera. In Bolli, H.M., Saunders, J.B., and Perch-Nielsen, K. (Eds.), Plankton Stratigraphy: Cambridge (Cambridge Univ. Press), 263-282.

Laverne, C., Belarouchi, A., and Honnorez, J., 1996. Alteration mineralogy and chemistry of the upper oceanic crust from Hole 896A, Costa Rica rift. In Alt, J.C., Kinoshita, H., Stokking, L.B., and Michael, P.J. (Eds.), Proc. ODP, Sci. Results, 148: College Station, TX (Ocean Drilling Program), 151-170. doi:10.2973/ odp.proc.sr.148.127.1996

Leckie, R.M., Farnham, C., and Schmidt, M.G., 1993. Oligocene planktonic foraminifer biostratigraphy of Hole 803D (Ontong Java Plateau) and Hole 628A (Little Bahama Bank), and comparison with the southern high latitudes. In Berger, W.H., Kroenke, L.W., Mayer, L.A., et al., Proc. ODP, Sci. Results, 130: College Station, TX (Ocean Drilling Program), 113-136. doi:10.2973/ odp.proc.sr.130.012.1993

Pearson, P.N., Olsson, R.K., Huber, B.T., Hemleben, C., and Berggren, W.A. (Eds.), 2006. Atlas of Eocene Planktonic Foraminifera. Spec. Publ.-Cushman Found. Foraminiferal Res., 41.

Rodriguez-Lázaro, J., and Cronin, T.M., 1999. Quaternary glacial and deglacial Ostracoda in the thermocline of the Little Bahama Bank (NW Atlantic): palaeoceanographic implications. Palaeogeogr., Palaeoclimatol., Palaeoecol., 152(3-4):339-364. doi:10.1016/S00310182(99)00048-6

Savrda, C.E., and Bottjer, D.J., 1989. Trace-fossil model for reconstructing oxygenation histories of ancient marine bottom waters: application to upper Cretaceous Niobrara Formation, Colorado. Palaeogeogr., Palaeoclimatol., Palaeoecol., 74: 49-74. doi:10.1016/00310182(89)90019-9

Sheppard, R.A., Gude, A.J., III, and Griffin, J.J., 1970. Chemical composition and physical properties of phillipsite from the Pacific and Indian Oceans. Am. Mineral.,
55: 2053-2062. http://www.minsocam.org/ammin/ AM55/AM55_2053.pdf

Shipboard Scientific Party, 1987. Site 596: hydraulic piston coring in an area of low surface productivity in the southwest Pacific. In Menard, H.W., Natland, J.H., Jordan, T.H., Orcutt, J.A., et al., Init. Repts. DSDP, 91: Washington, DC (U.S. Govt. Printing Office), 245-270. doi:10.2973/dsdp.proc.91.103.1987

Stonecipher, S.A., 1976. Origin, distribution, and diagenesis of deep-sea clinoptilolite and phillipsite in deep-sea sediments. Chem. Geol., 17:307-318. doi:10.1016/ 0009-2541(76)90044-9

Talley, L.D., 2007. Hydrographic Atlas of the World Ocean Circulation Experiment (WOCE) (Vol. 2): Pacific Ocean. Sparrow, M., Chapman, P., and Gould, J. (Eds.): Southampton, U.K. (International WOCE Project Office). http://www-pord.ucsd.edu/whp_atlas/ pacific_index.html

Teagle, D.A.H., Alt, J.C., Bach, W., Halliday, A.N., and Erzinger, J., 1996. Alteration of upper ocean crust in a ridge-flank hydrothermal upflow zone: mineral, chemical, and isotopic constraints from Hole 896A. In Alt, J.C., Kinoshita, H., Stokking, L.B., and Michael, P.J. (Eds.), Proc. ODP, Sci. Results, 148: College Station, TX (Ocean Drilling Program), 119-150. doi:10.2973/ odp.proc.sr.148.113.1996

Teagle, D.A.H., Alt, J.C., Umino, S., Miyashita, S., Banerjee, N.R., Wilson, D.S., and Expedition 309/312 Scientists, 2006. Proc. IODP, 309/312: Washington, DC (Integrated Ocean Drilling Program Management International, Inc.). doi:10.2204/iodp.proc.309312.2006

Tebbens, S.F., and Cande, S.C., 1997. Southeast Pacific tectonic evolution from early Oligocene to Present. J. Geophys. Res., [Solid Earth], 102(B6):12061-12084. doi:10.1029/96JB02582

Wade, B.S., Berggren, W.A., and Olsson, R.K., 2007. The biostratigraphy and paleobiology of Oligocene planktonic foraminifera from the equatorial Pacific Ocean (ODP Site 1218). Mar. Micropaleontol., 62(3):167-179. doi:10.1016/j.marmicro.2006.08.005

Wade, B.S., Pearson, P.N., Berggren, W.A., and Pälike, H., 2011. Review and revision of Cenozoic tropical planktonic foraminiferal biostratigraphy and calibration to the geomagnetic polarity and astronomical time scale. Earth-Sci. Rev., 104(1-3):111-142. doi:10.1016/j.earscirev.2010.09.003

Publication: 13 December 2011 MS 329-105 
Figure F1. Multibeam bathymetry of the Site U1367 survey area with the KNOX-02RR survey track overlain. sol = start of seismic line, eol = end of seismic line, $\mathrm{z}=$ time (Greenwich Mean Time), $\mathrm{sp}=$ shotpoint.

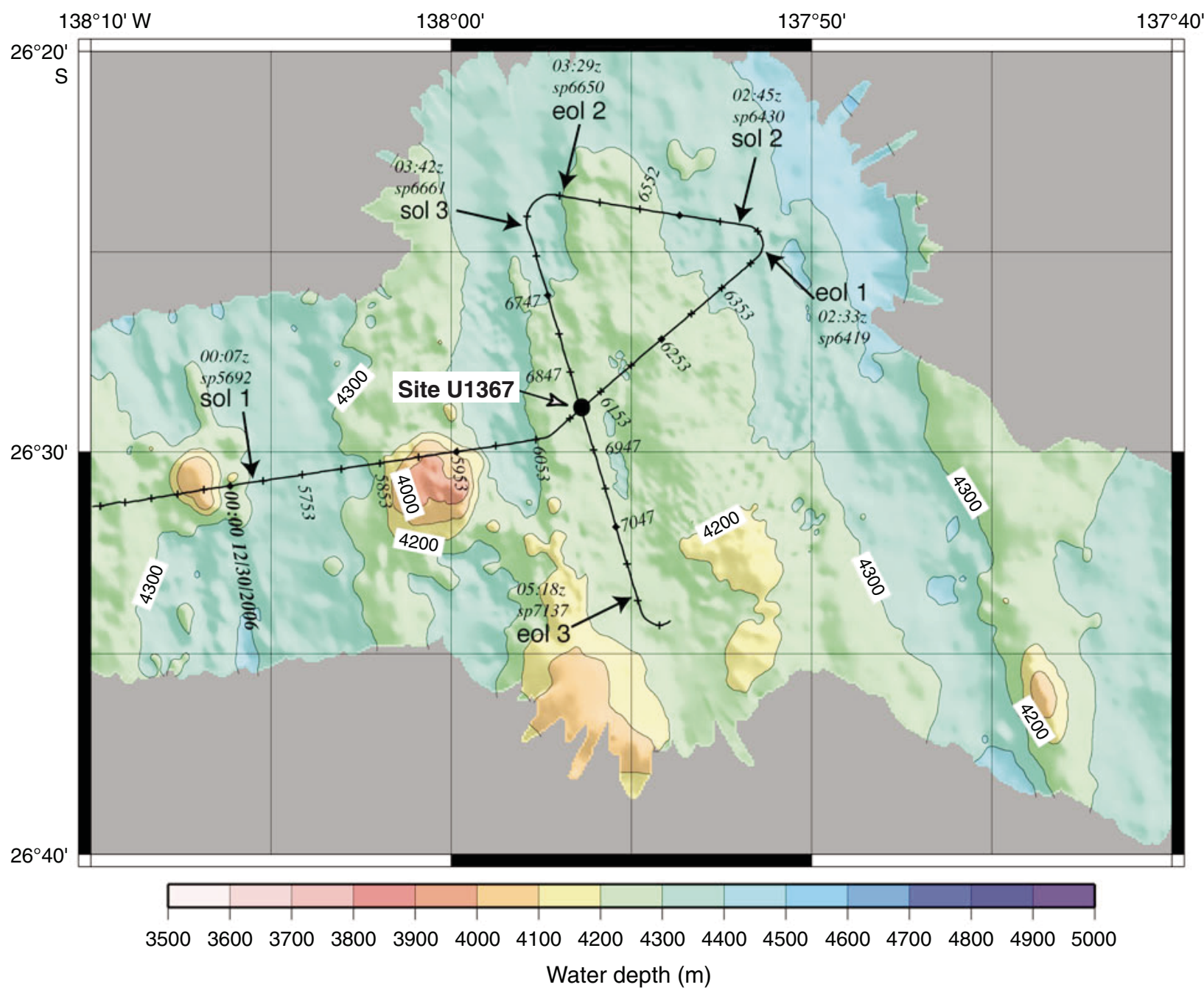


Figure F2. KNOX-02RR seismic survey track, Site U1367. sol = start of seismic line, eol = end of seismic line, z = time (Greenwich Mean Time), sp = shotpoint.

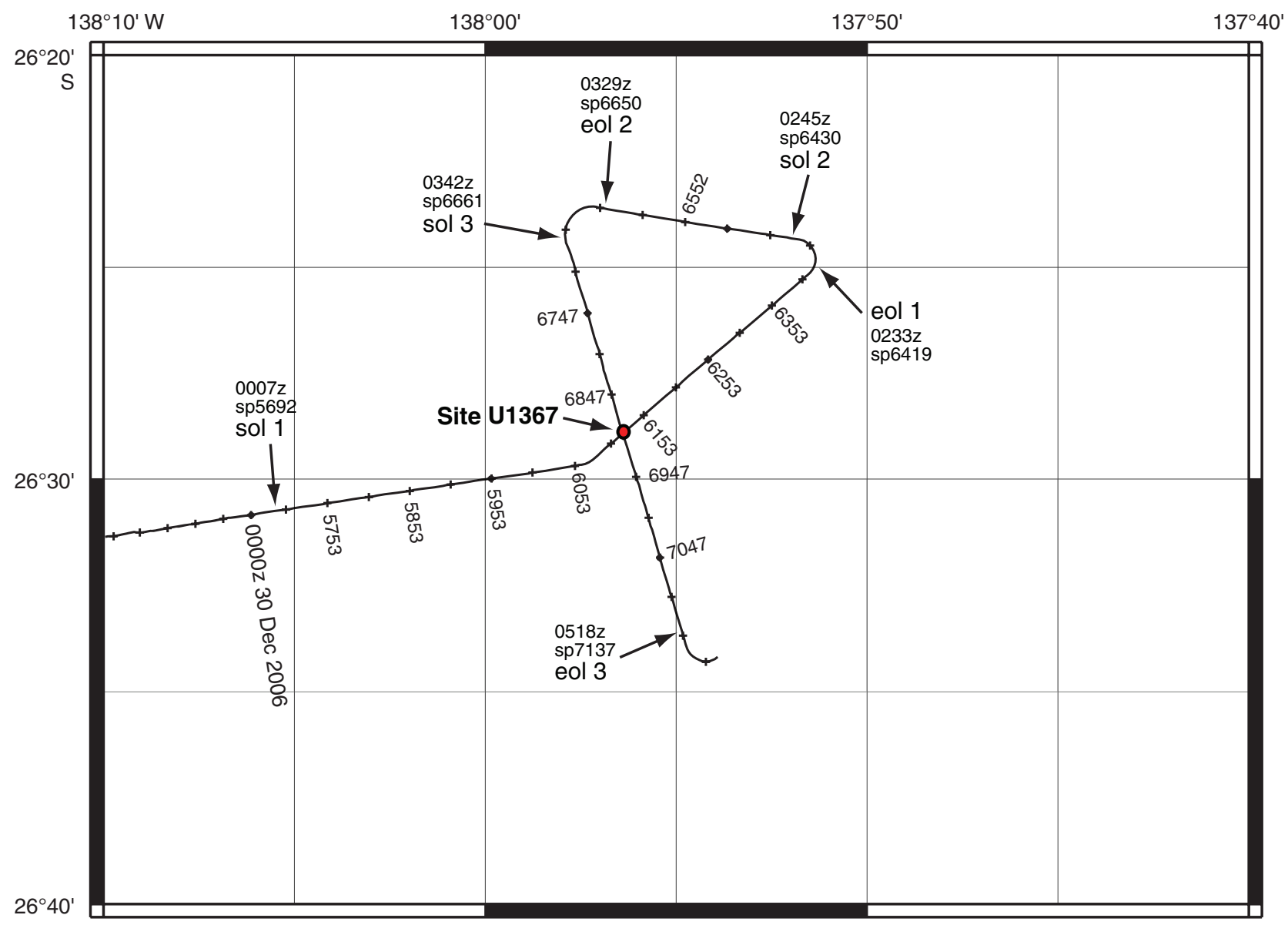


Figure F3. Portion of KNOX-02RR Channel 48 of MCS Line 3 across Site U1367. $z=$ time (Greenwich Mean Time), SP $=$ shotpoint, MORB $=$ midocean-ridge basalt, $\mathrm{WD}=$ water depth, $\mathrm{SCS}=$ single-channel seismic, $\mathrm{BP}=$ band-pass, $\mathrm{AGC}=$ automatic gain control, $\mathrm{VE}=$ vertical exaggeration .

Shotpoint

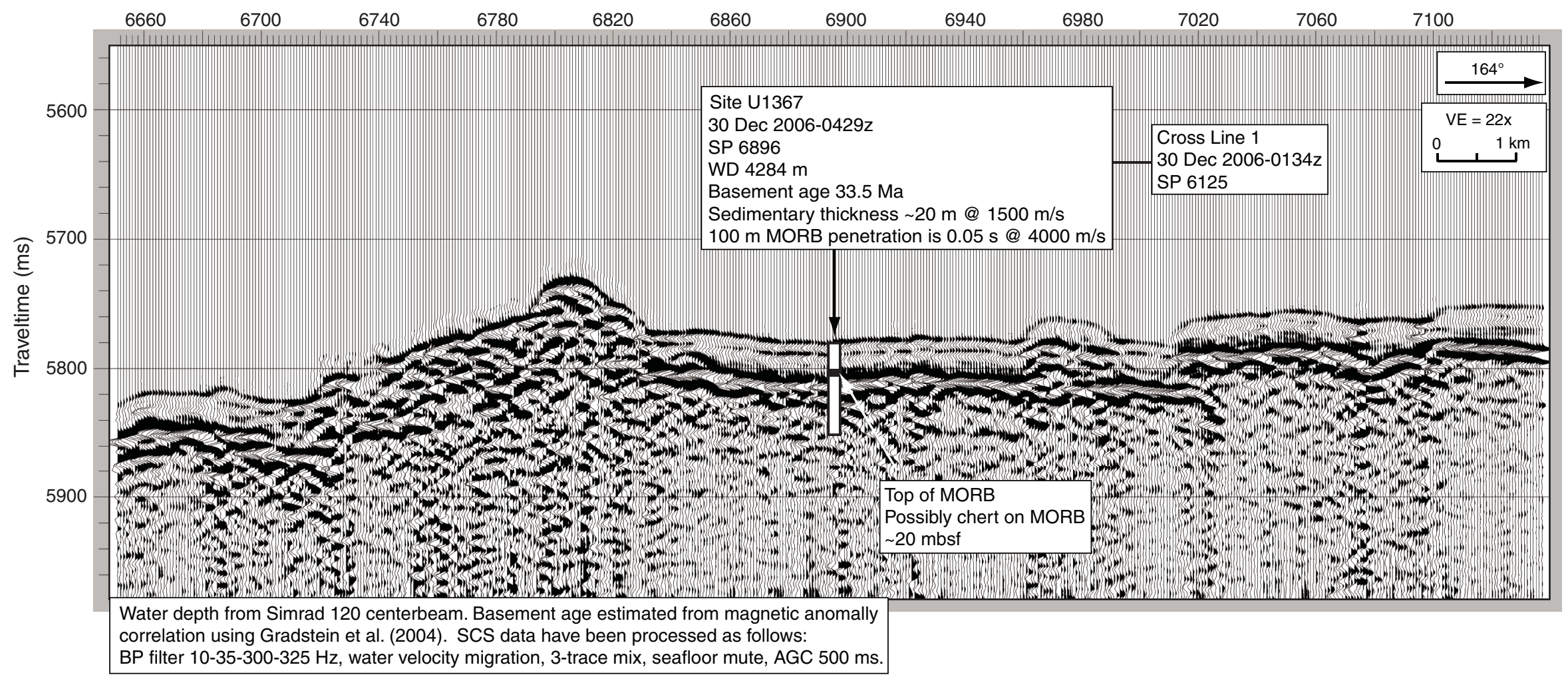


Figure F4. Portion of KNOX-02RR Channel 48 of MCS Line 1 crossing MCS Line 3, northeast of Site U1367. SP = shotpoint, VE = vertical exaggeration.

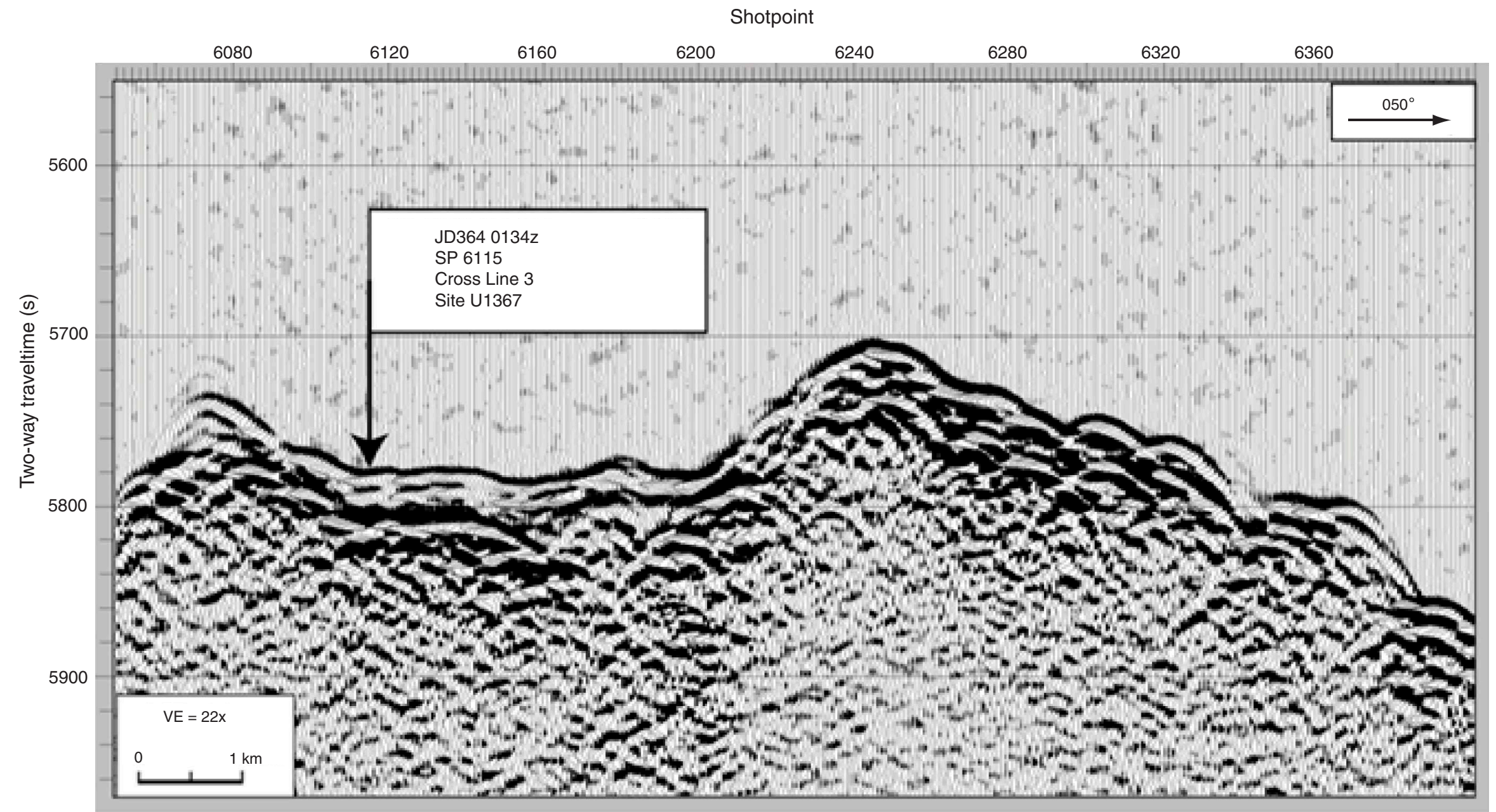


Figure F5. Portion of KNOX-02RR $3.5 \mathrm{kHz}$ seismic Line 3 across Site U1367.

Time ( $\mathrm{z})$

0414

0430

0447

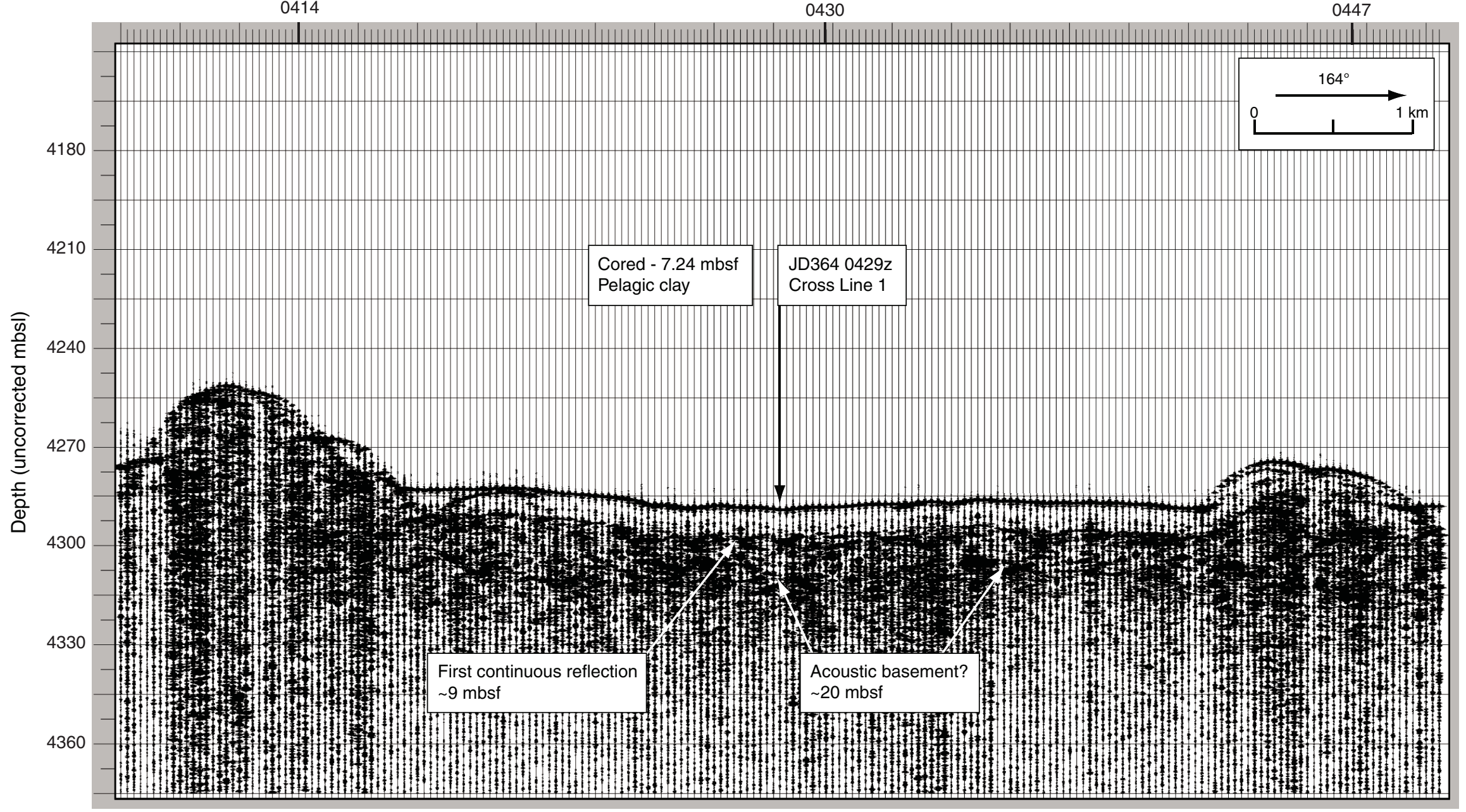


Figure F6. Portion of KNOX-02RR 3.5 kHz seismic Line 1 crossing 3.5 kHz seismic Line 3, northeast of Site U1367.

Time (z)

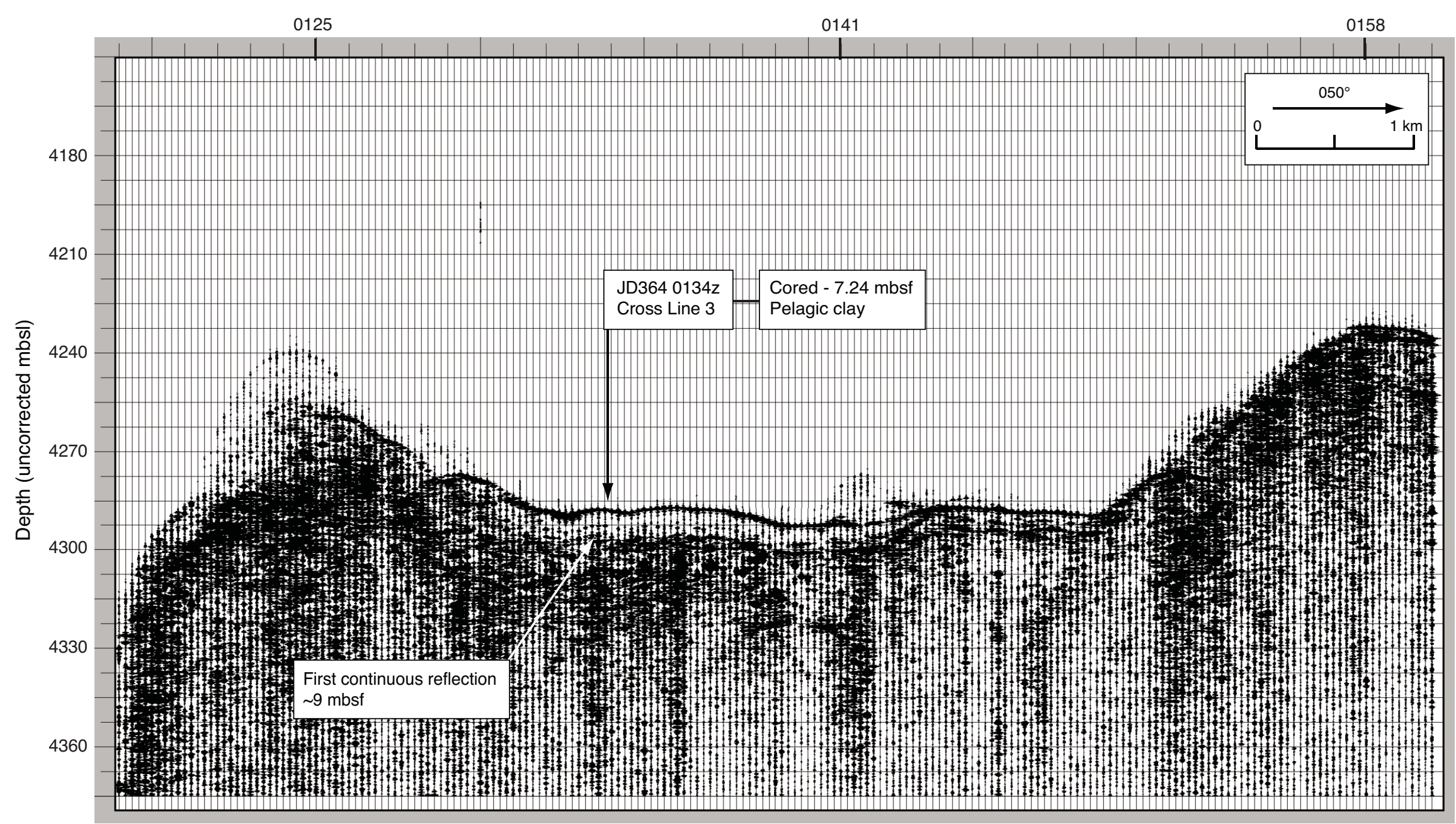


Figure F7. Lithology summary and physical property data, Site U1367. MS = magnetic susceptibility, GRA = gamma ray attenuation, $\mathrm{K}=$ absolute potassium concentration in percent, based on analysis of spectral gamma ray responses, $\mathrm{NGR}$ = natural gamma radiation, $\mathrm{RSO}$ = red-brown to yellow-brown semiopaque oxide. A. Hole U1367B. (Continued on next page.)

A

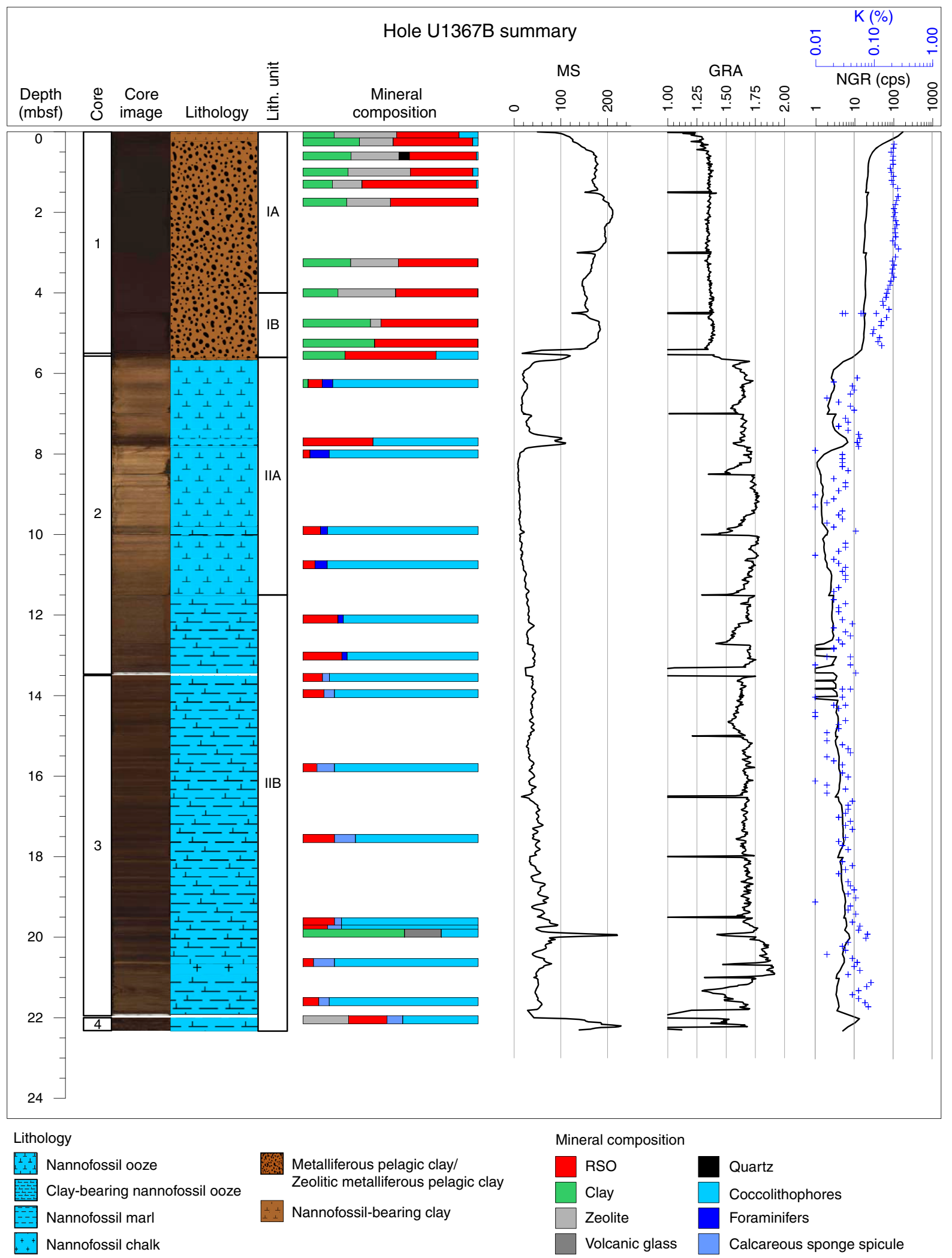


Figure F7 (continued). B. Hole U1367E.

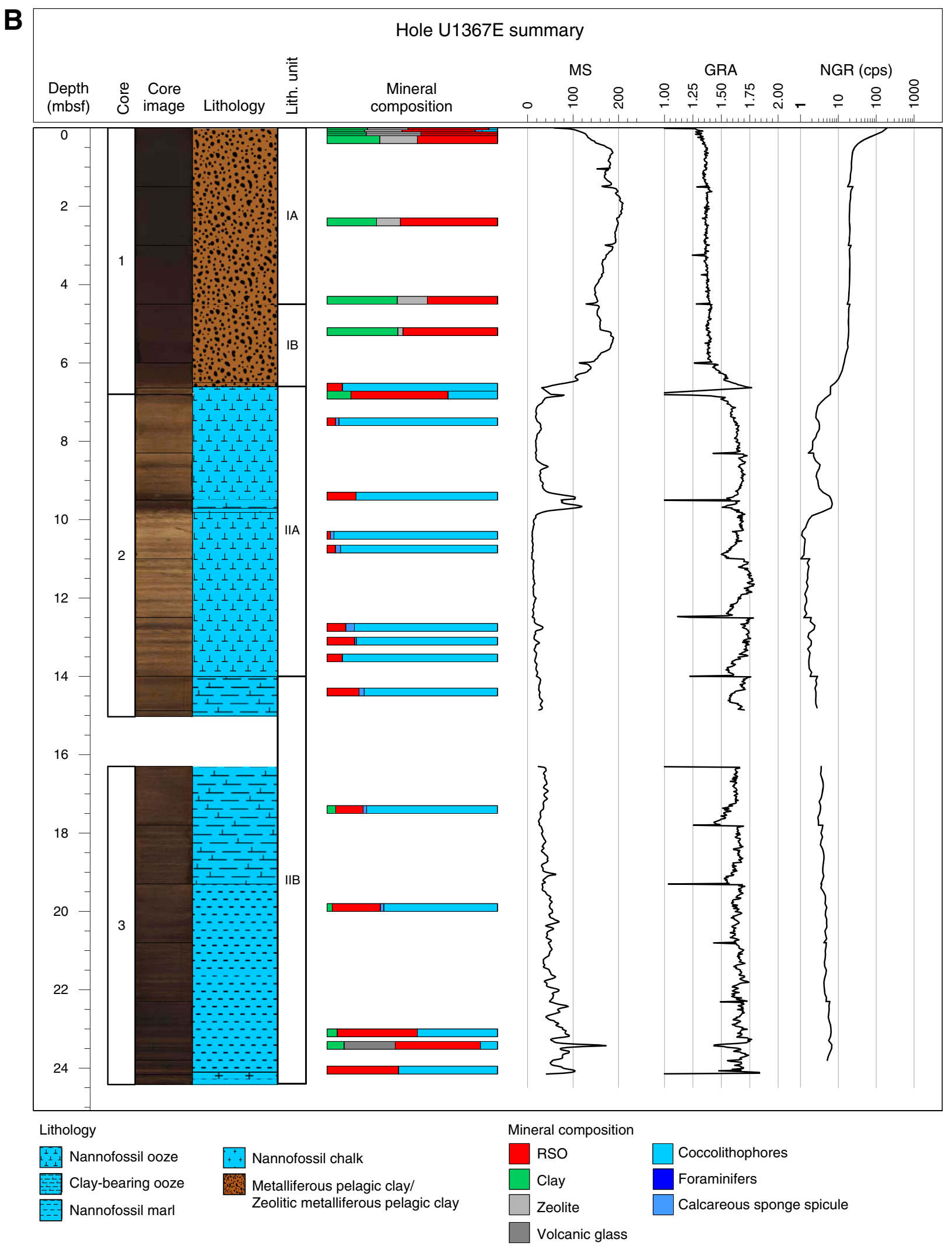


Figure F8. Lithostratigraphic correlation among holes at Site U1367. H1 = dark brown nannofossil marl or clay-bearing nannofossil ooze layer in the uppermost part of Subunit IIA, H2 = ash layer in the lowermost part of Subunit IIB.
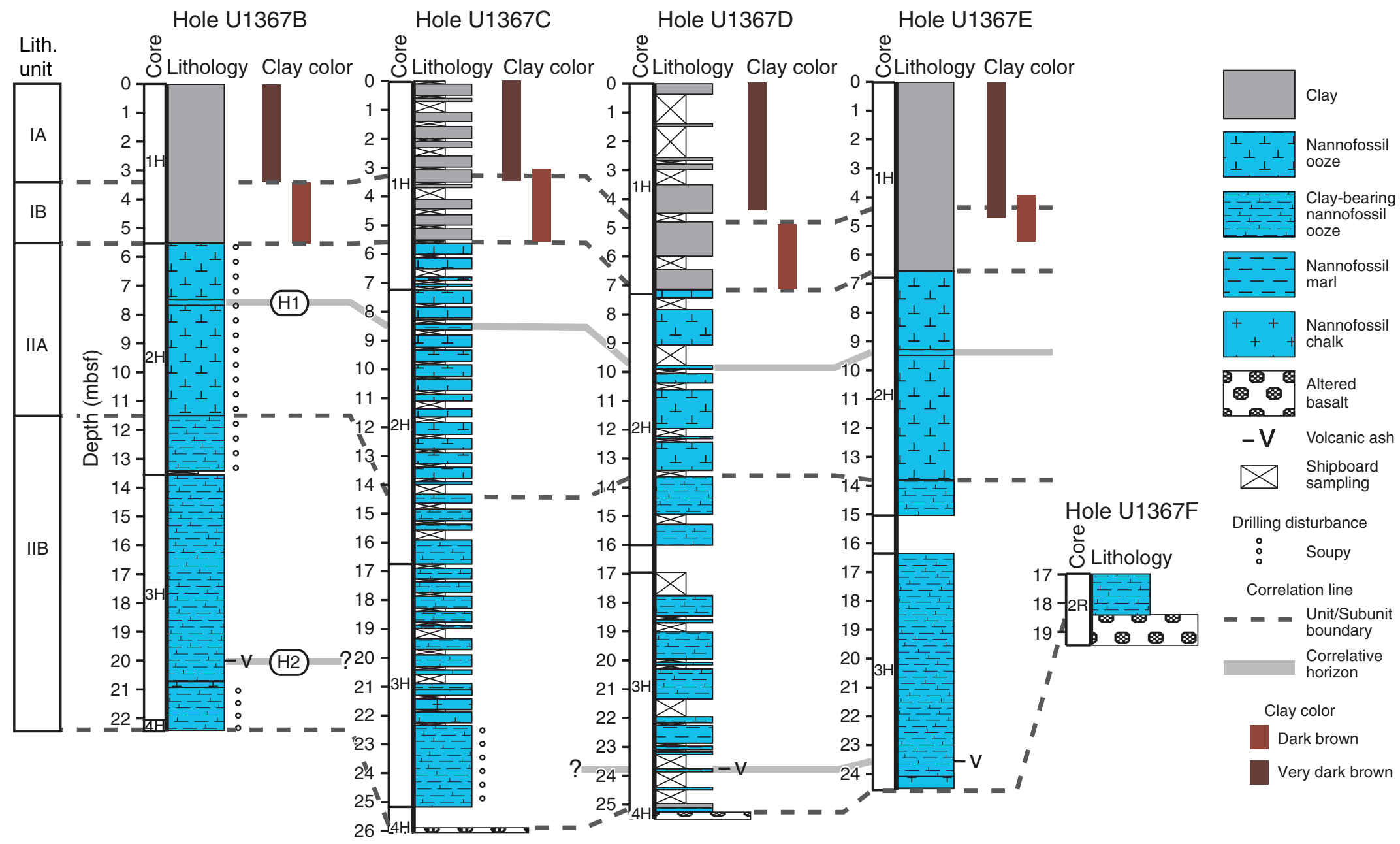
Figure F9. Representative core photographs, Site U1367. A. Dark brown zeolitic metalliferous pelagic clay in Subunit IA (interval 329-U1367B-1H-2, 0-40 cm). B. Dark brown metalliferous pelagic clay in Subunit IB (interval 329-U1367B-1H-4, 50-90 cm). C. Pink nannofossil ooze in Subunit IIA. Two light brown intercalated layers are recognizable at 120-130 and 140-146 cm (interval 329-U1367C-2H-2, 110-150 cm). D. Transition from dark brown clay-bearing nannofossil ooze to pink nannofossil ooze, showing well-preserved burrows (interval 329-U1367E-2H-3, 20-60 cm). E. Dark brown clay-bearing nannofossil ooze in Subunit IIB with frequent mottles and nannofossil-rich brown layers (interval 329-U1367B-3H-2, 100-140 cm). F. Base of Subunit IIB with moderately consolidated yellow nannofossil chalk (interval 329-U1367C-3H-4, 60-100 cm). (Figure shown on next page.) 

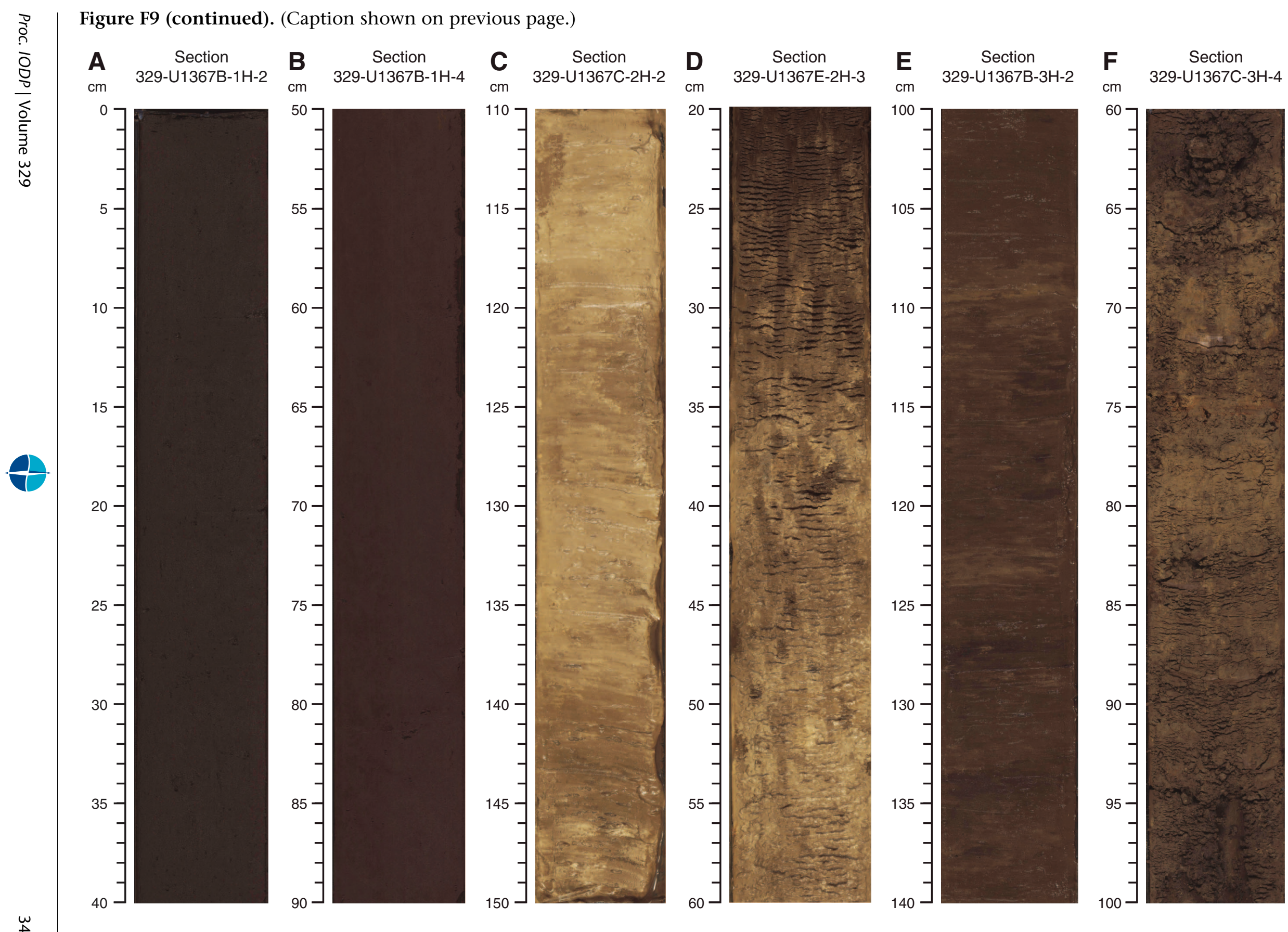
Figure F10. X-ray diffractograms of bulk sediment samples, Hole U1367B. A. Numerous peaks associated with phillipsite (P) in Subunit IA. (Continued on next two pages.)

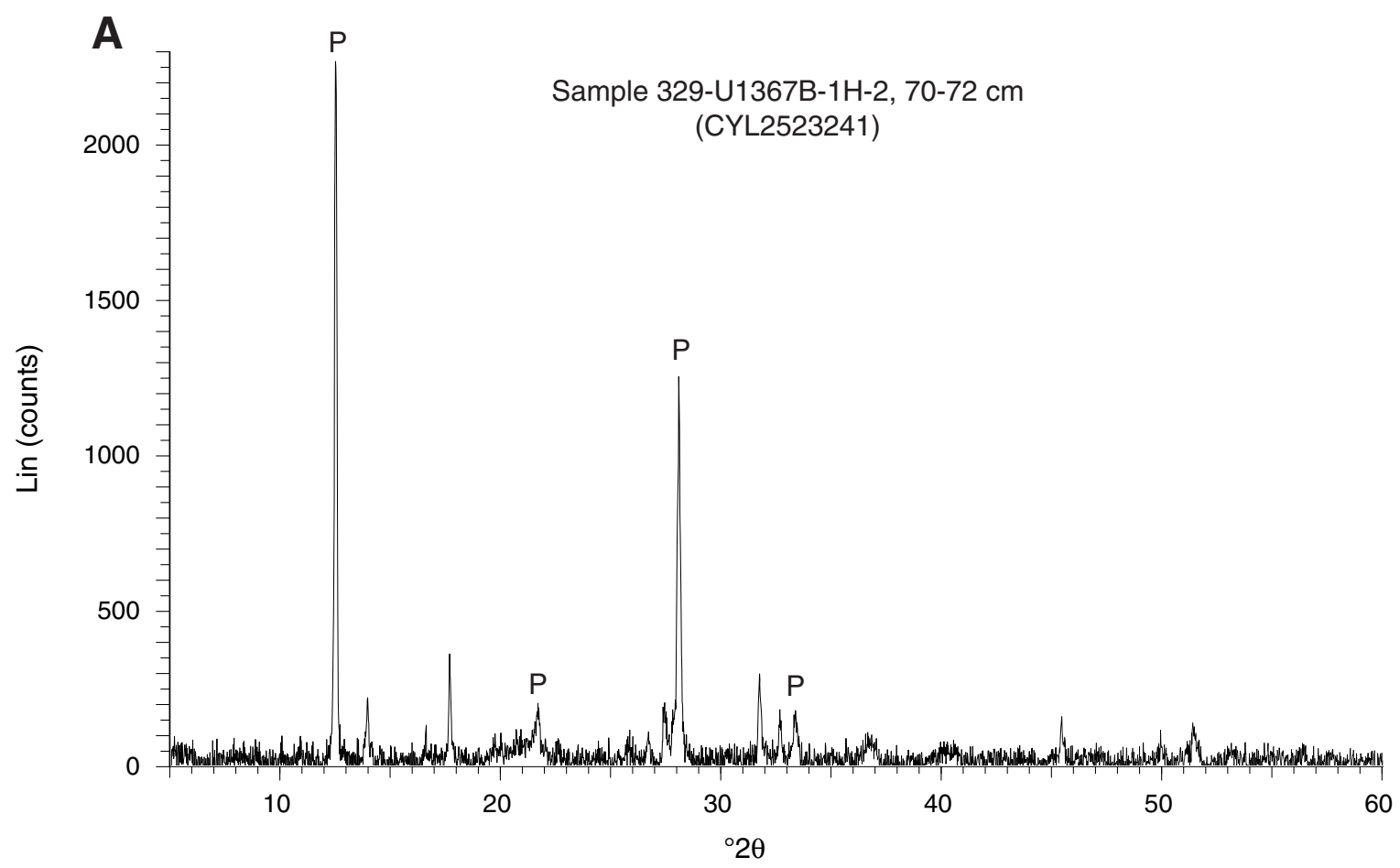


Figure F10 (continued). B. Two calcite patterns from Subunit IIA. The origin of the minor offset in patterns is unknown; however, it is not due to variable sampling, preparation, or analytical methods. (Continued on next page.)

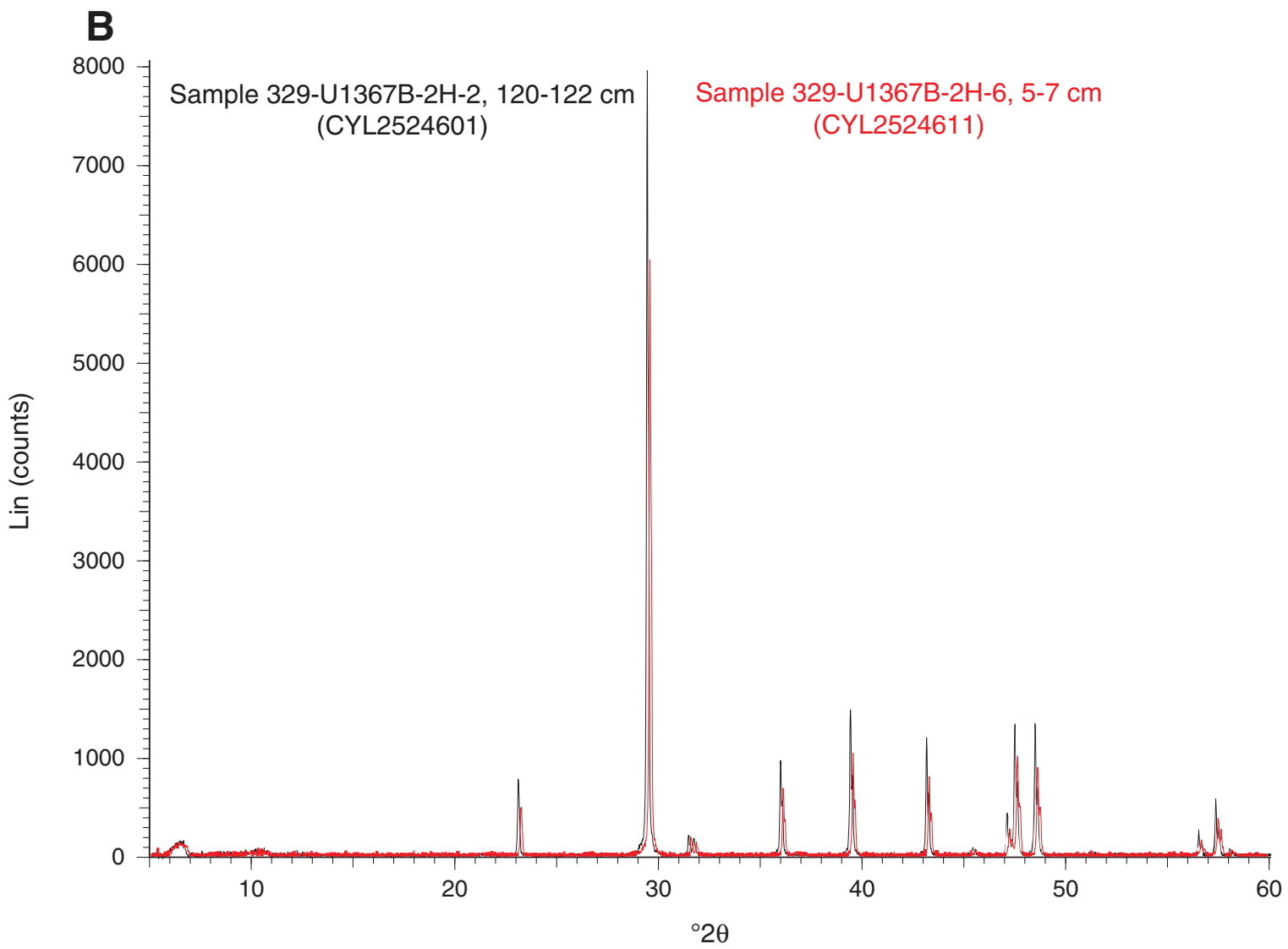


Figure F10 (continued). C. Lower part of Subunit IIB illustrating the unit's uniform calcite composition.

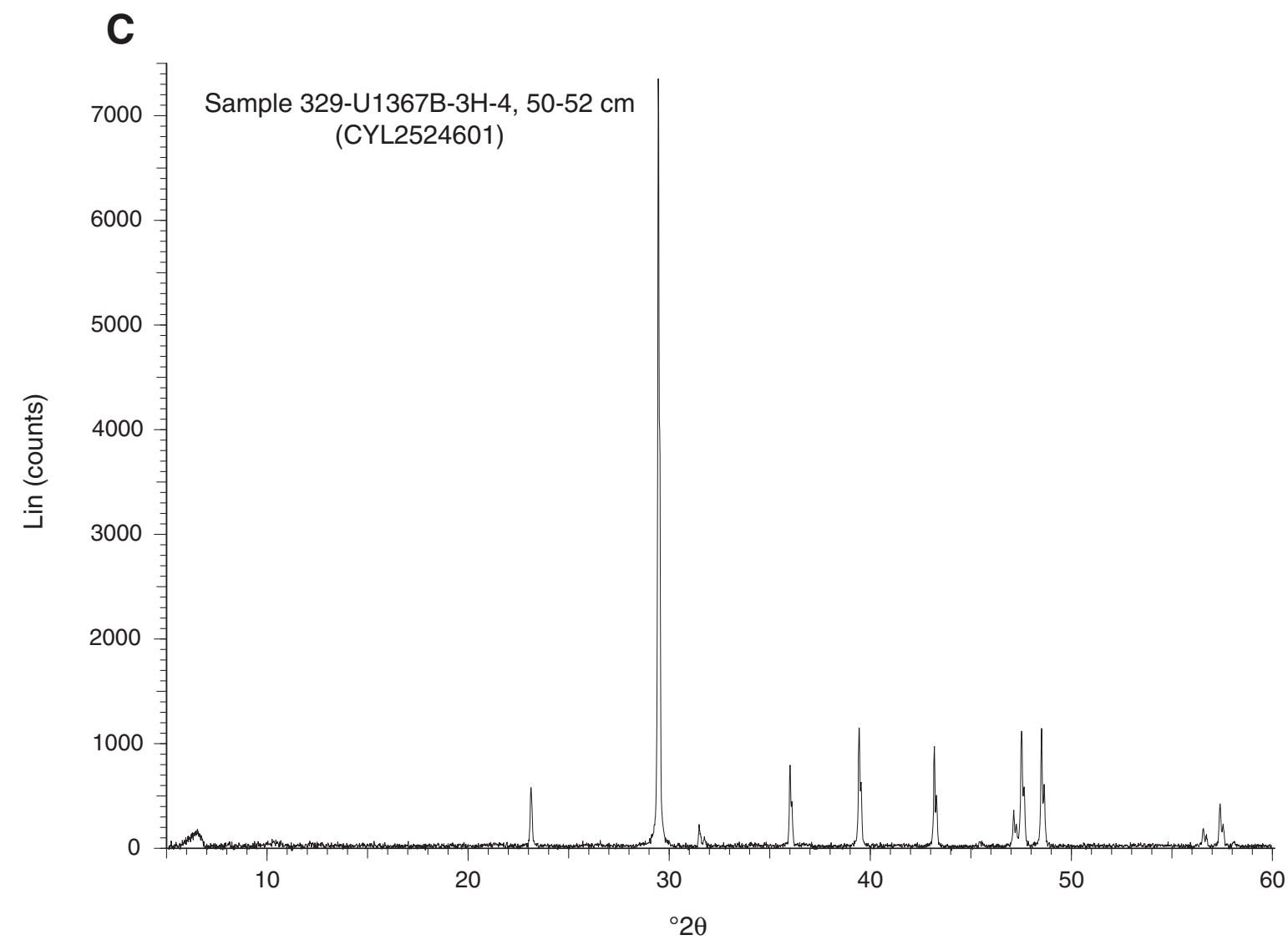


Figure F11. Smear slide photomicrographs of clay sediment, Site U1367. A. Zeolitic metalliferous pelagic clay in Subunit IA (Sample 329-U1367C1H-1, $30 \mathrm{~cm}$ ). B. Metalliferous clay in Subunit IB (Sample 329-U1367C-1H-4, $20 \mathrm{~cm}$ ). C. Nannofossil ooze in Subunit IIA (Sample 329-U1367C1H-5, 85 cm). D. Clay-bearing nannofossil ooze in Subunit IIB (Sample 329-U1367C-3H-3, 40 cm).

A

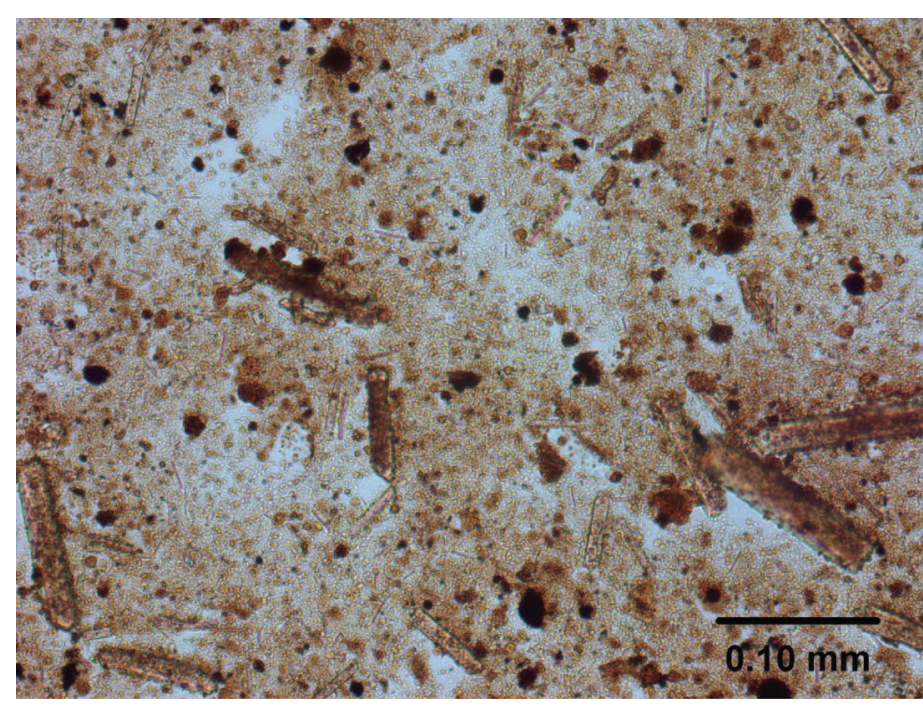

C

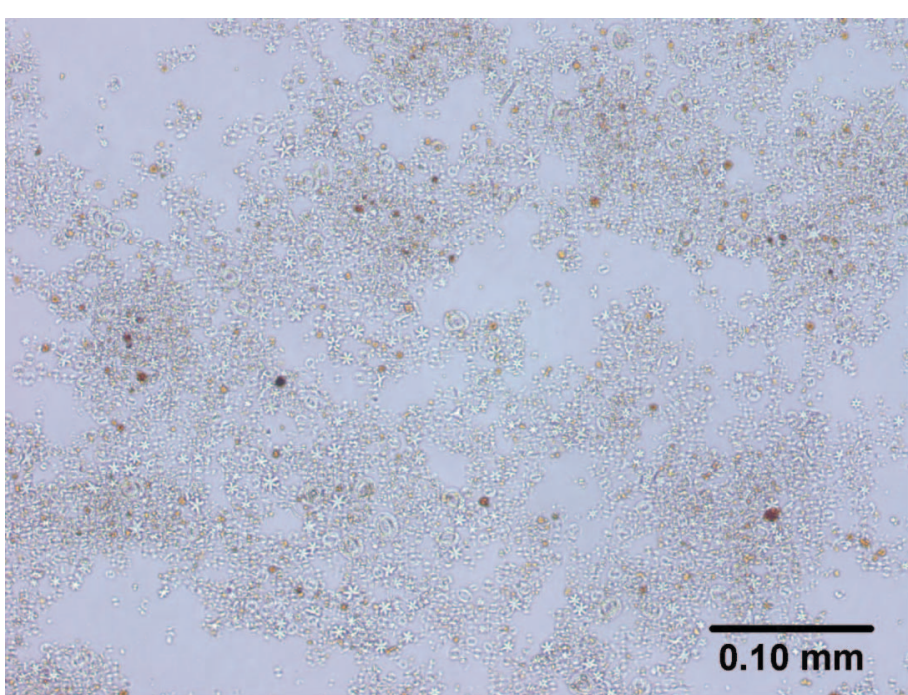

B

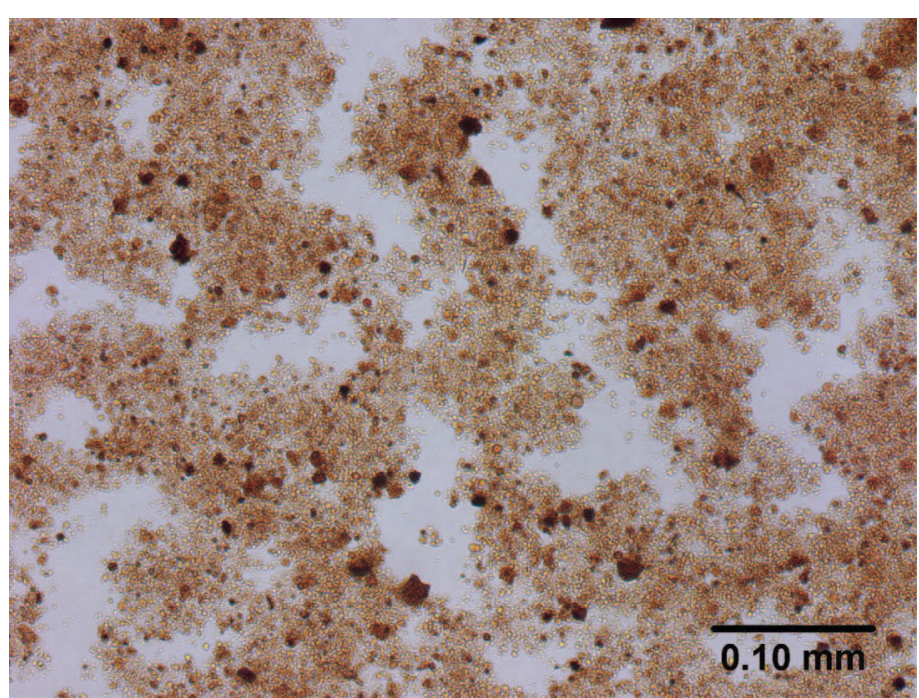

D

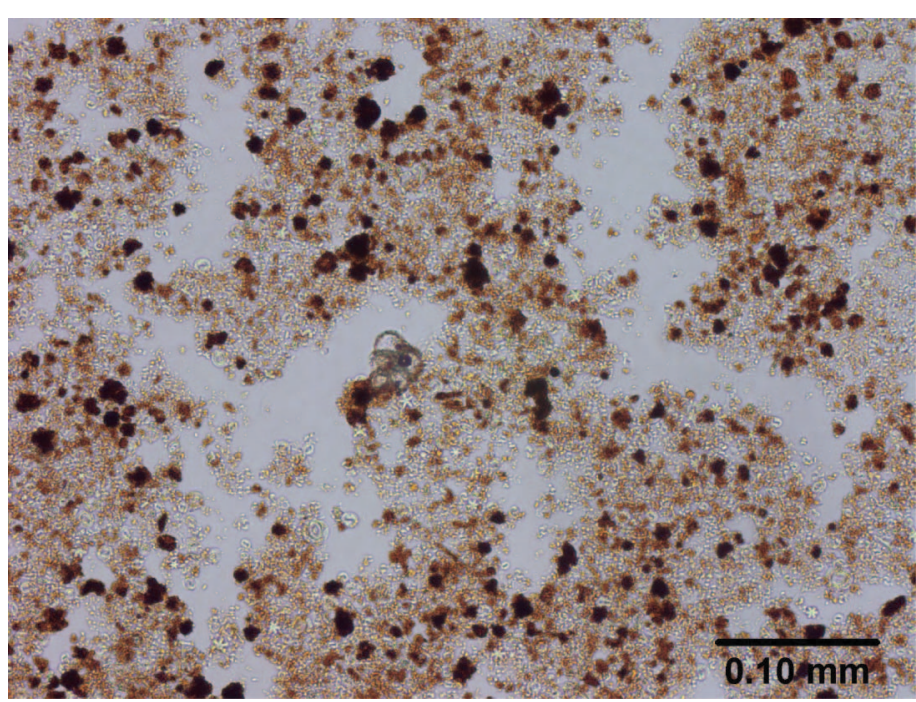


Figure F12. Generalized stratigraphy for basement recovered at Site U1367. Arrows indicate the potential location of the unoriented fragments from each core.

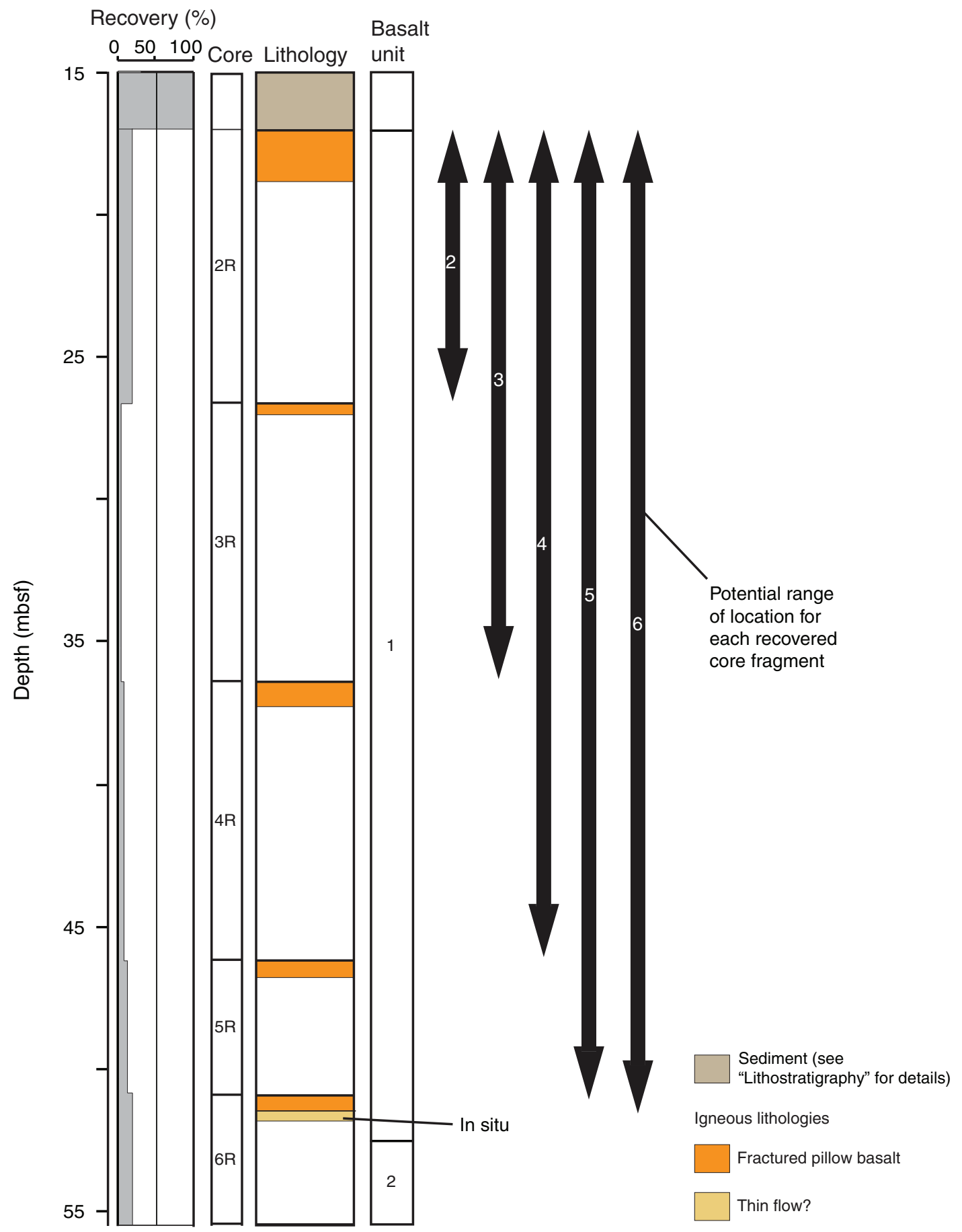


Figure F13. Photomicrographs of quenching structures exhibiting increasing groundmass crystal size away from the margin (Sample 329-U1367F-2R-3, 60-63 cm). Fe-ox = iron oxyhydroxide, TS = thin section. Planepolarized light at $5 \times$ magnification.

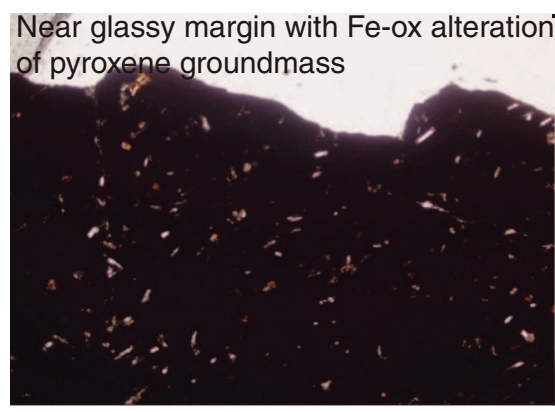

\section{Alteration front}
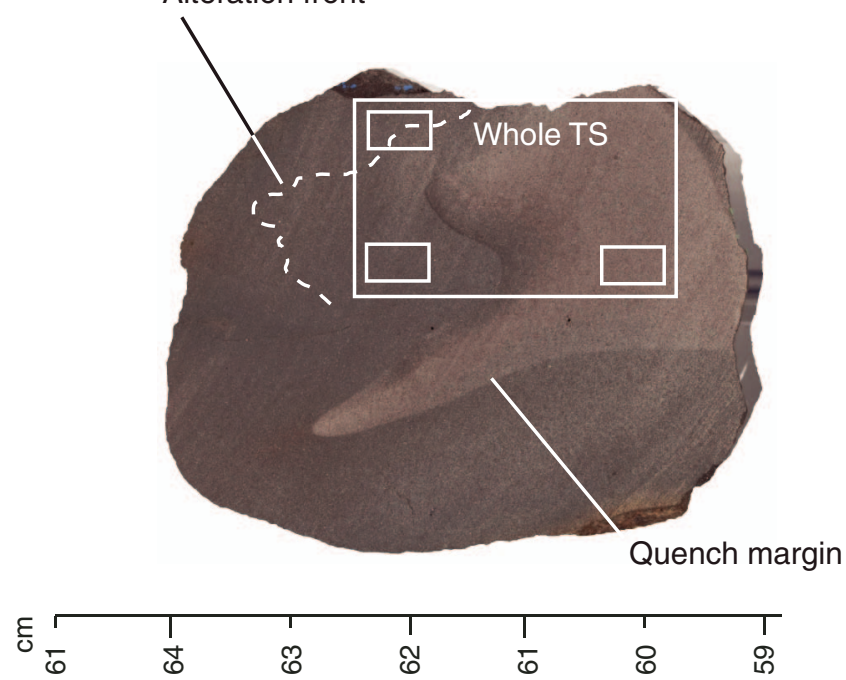
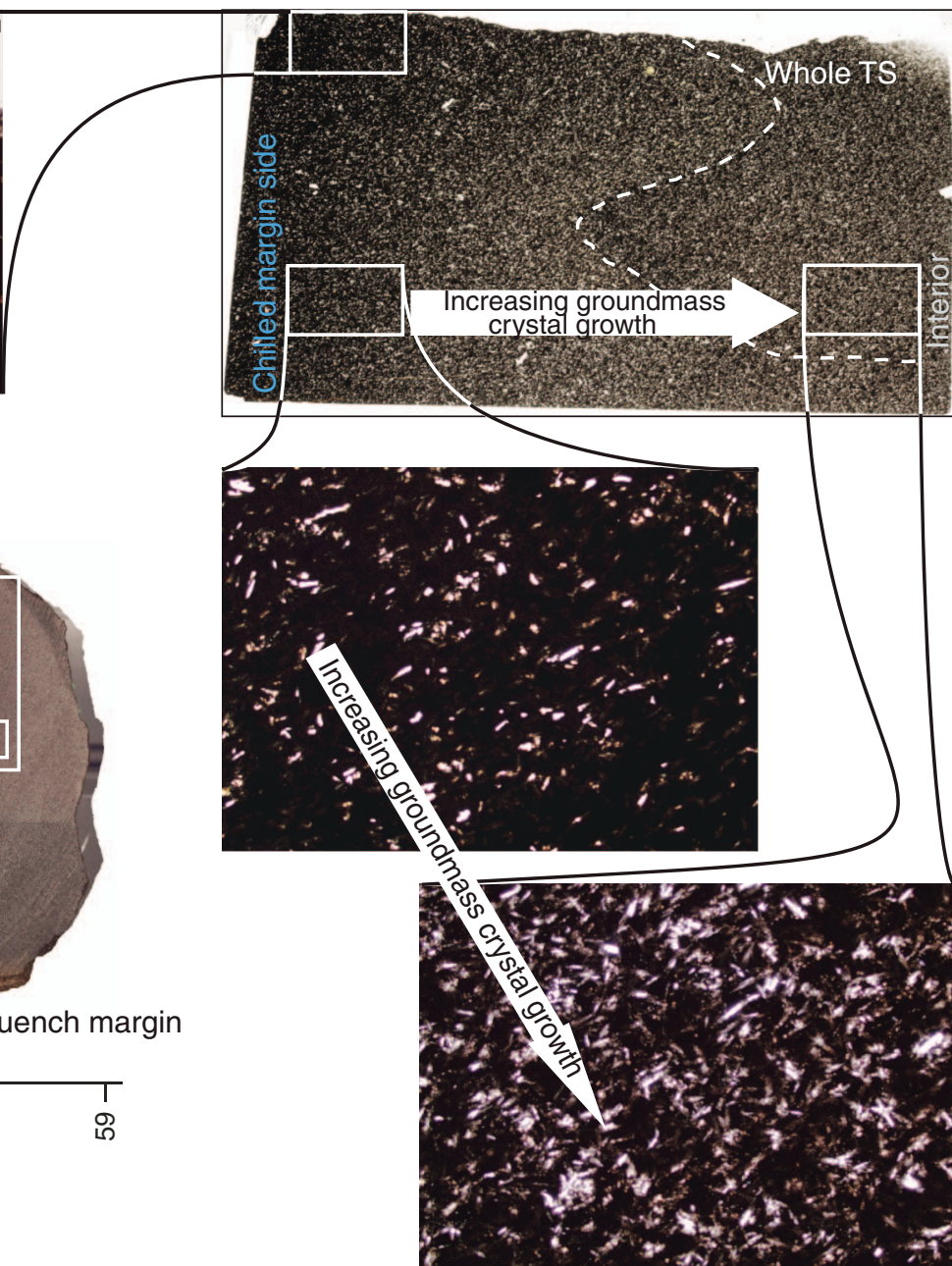
Figure F14. Photomicrographs of an iron oxyhydroxide pseudomorph of olivine and a brown saponitic alteration halo flanking a polymineralic vein of celadonite and iron oxyhydroxides (Sample 329-U1367F-4R-1, 51$53 \mathrm{~cm}$ ). Fe-ox = iron oxyhydroxide, $\mathrm{Cel}=$ celadonite, $\mathrm{Sap}=$ saponite. Top image is shown in plane-polarized light. Bottom image was taken in crossed polarized light at $5 \times$ magnification.
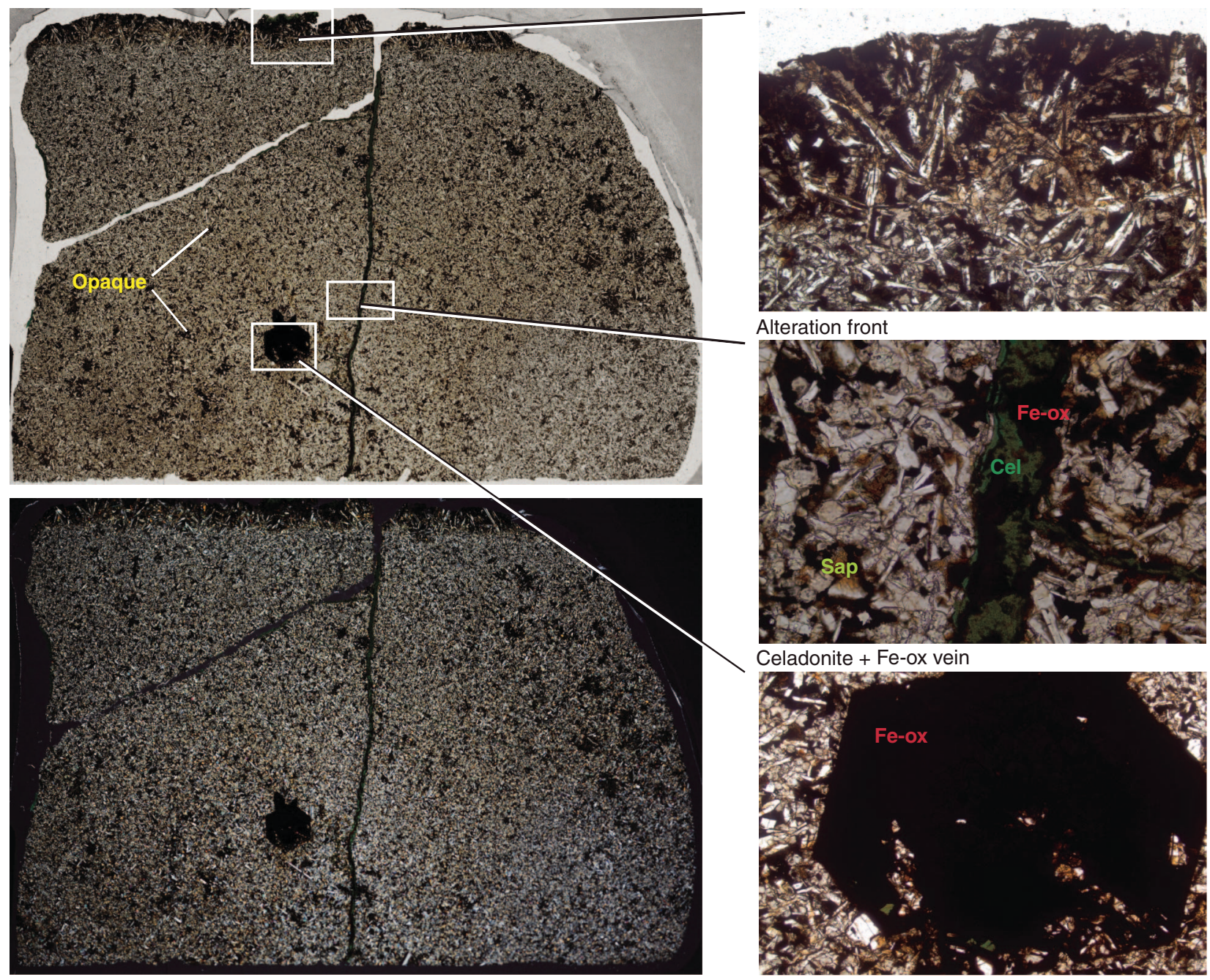

Alteration front
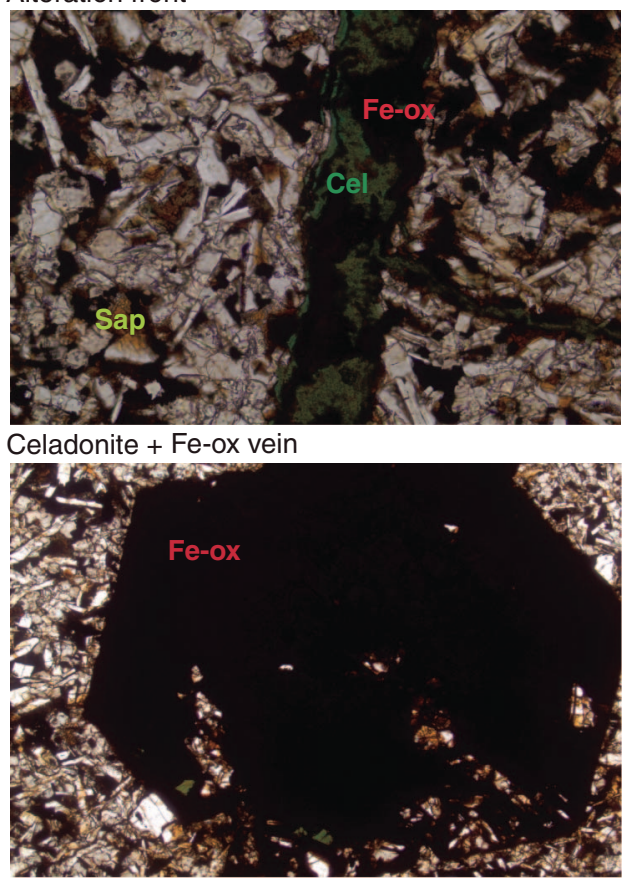

Altered olivine phenocryst 

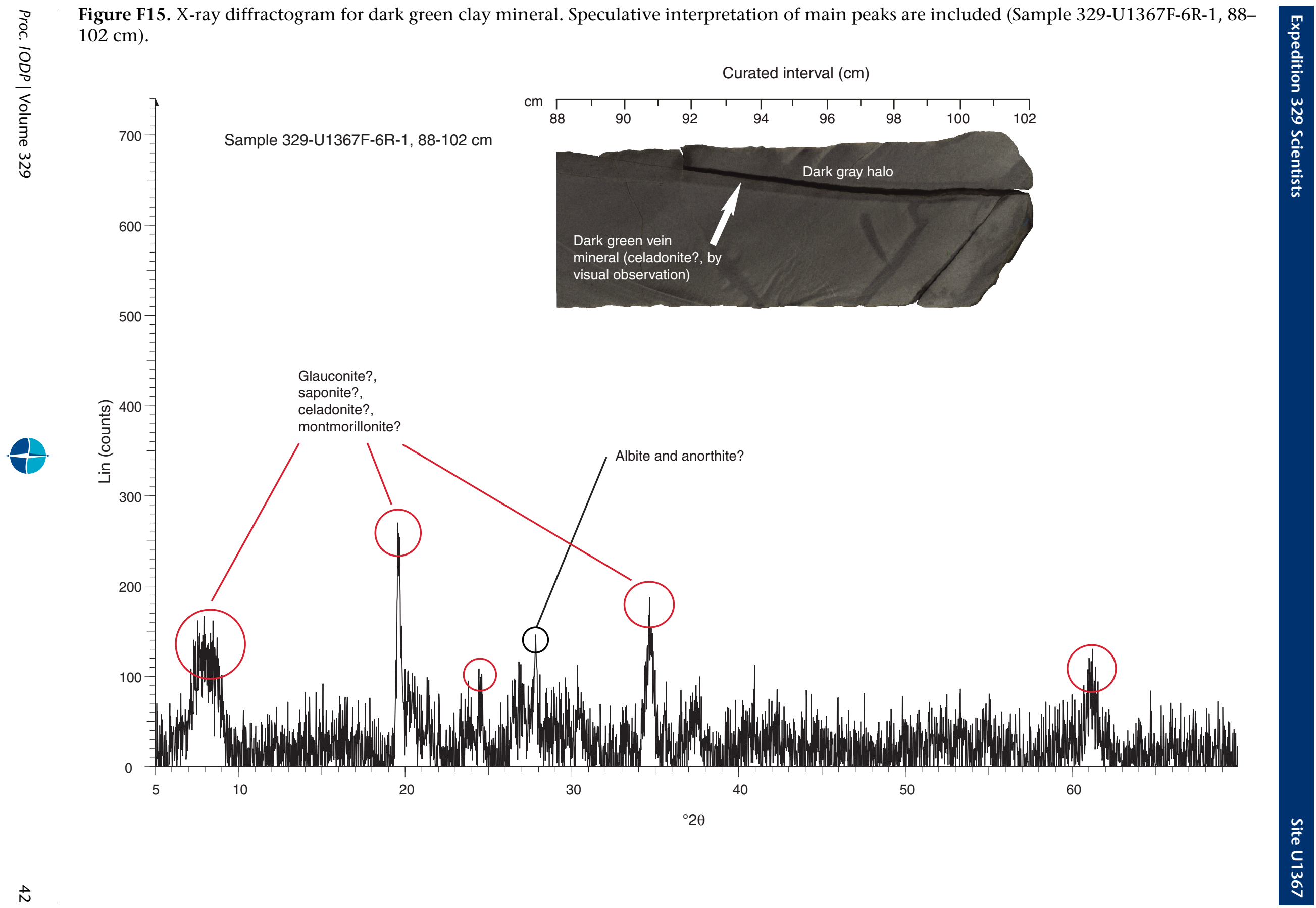
Figure F16. Altered over least altered major and trace element concentrations in brown basalt chips at the sediment/basement interface (red; Sample 329-U1367F-4R-1, 21-31 cm) and a chilled margin with very slight brown alteration (black; Sample 329-U1367F-4R-1, 51-53 cm). LOI = loss on ignition. Error bars are propagated from the sum of the squares of analytical precision (based on multiple runs of Sample 329-U1367F-2R-3, 60$63 \mathrm{~cm}$ ) (see "Lithostratigraphy, igneous petrology, alteration, and structural geology" in the "Methods" chapter [Expedition 329 Scientists, 2011a]).

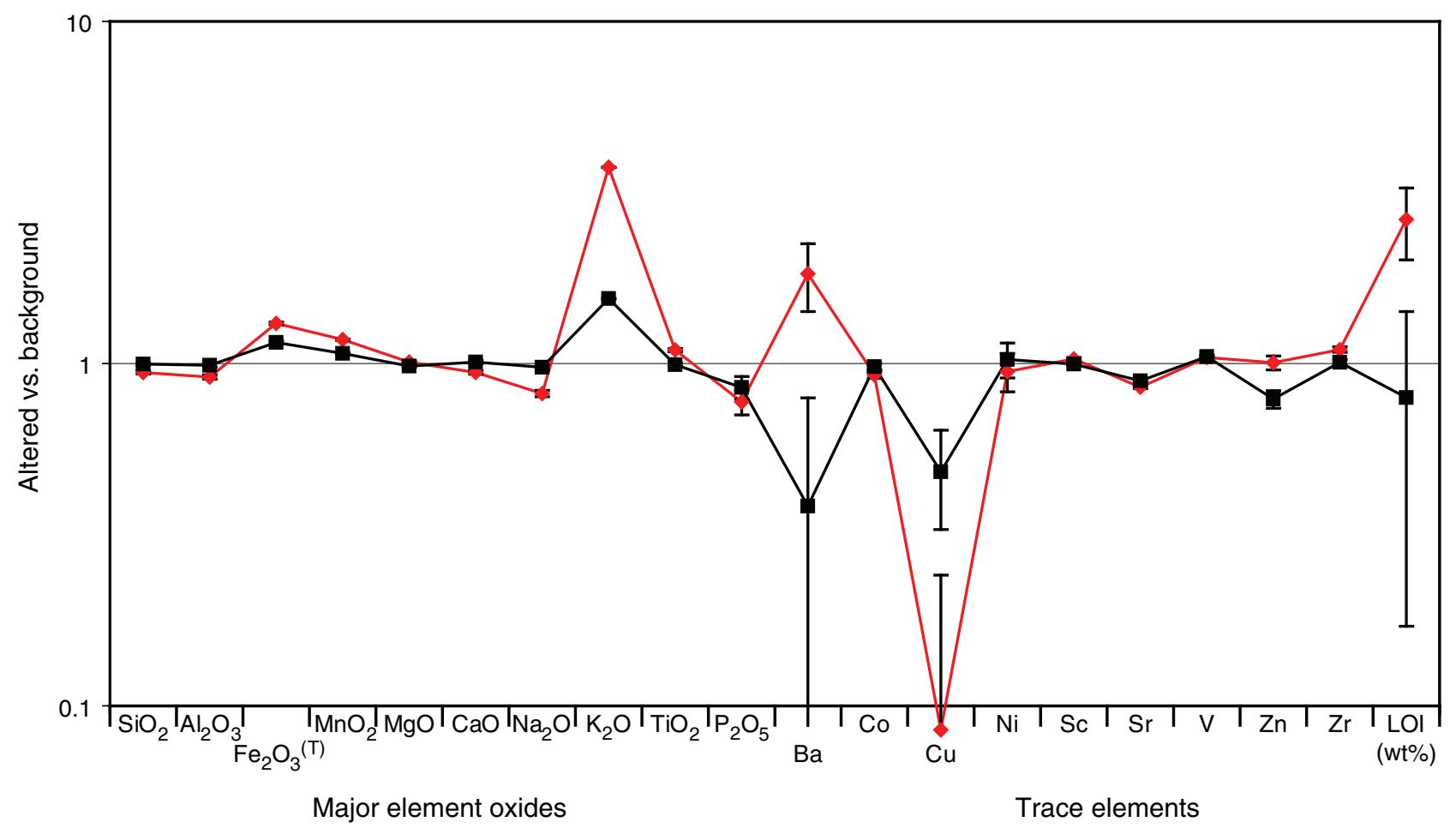


Figure F17. Lithology summary and preliminary biostratigraphy, Site U1367. Sample locations are indicated by arrows. Samples taken from holes other than Hole U1367B are noted by an asterisk (*). Ages of the foraminiferal zones are based on Wade et al. (2011). LO = last occurrence.

Site U1367 lithology summary

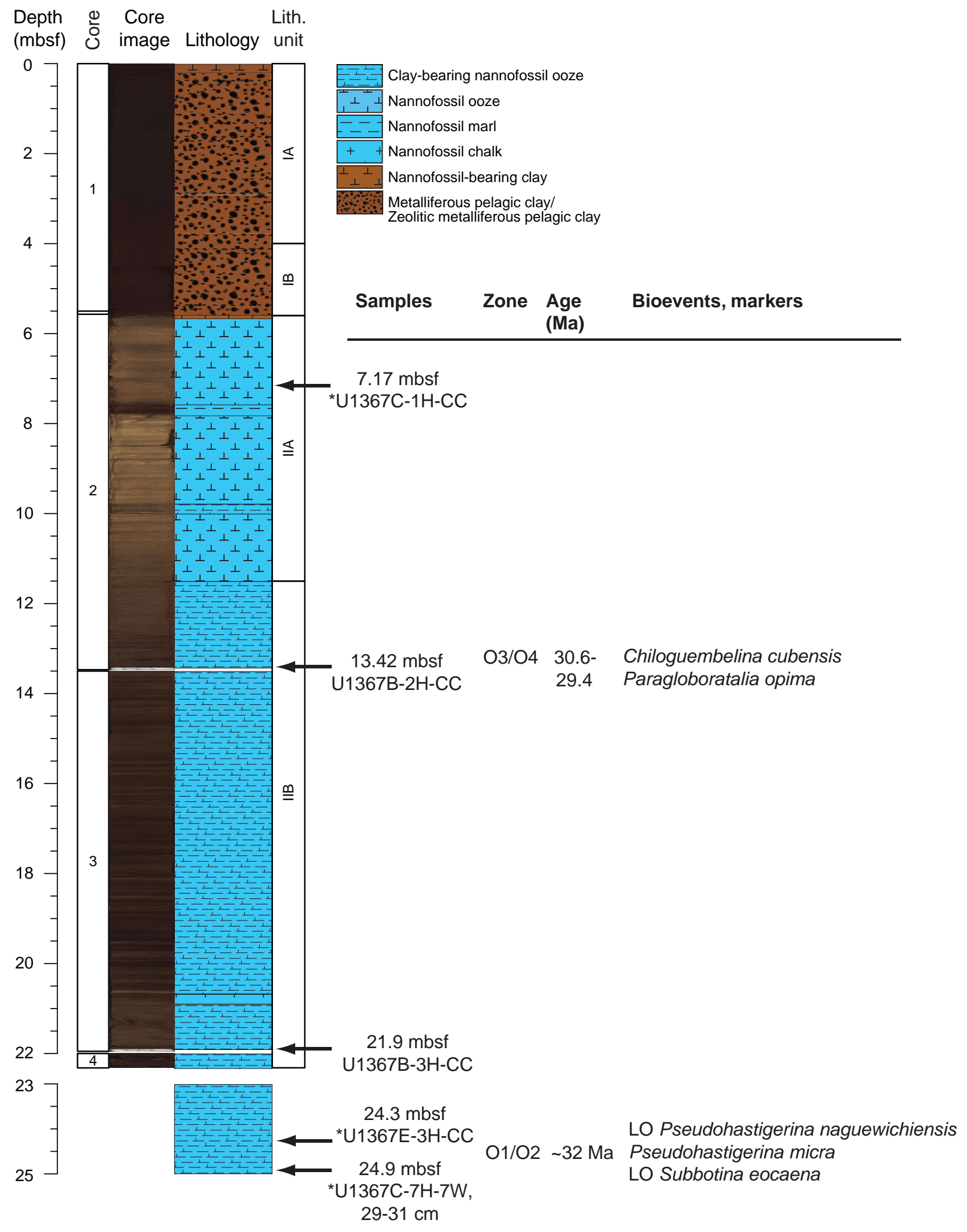


Figure F18. Photomicrograph of foraminiferal ooze (Sample 329-U1367B-2H-CC).

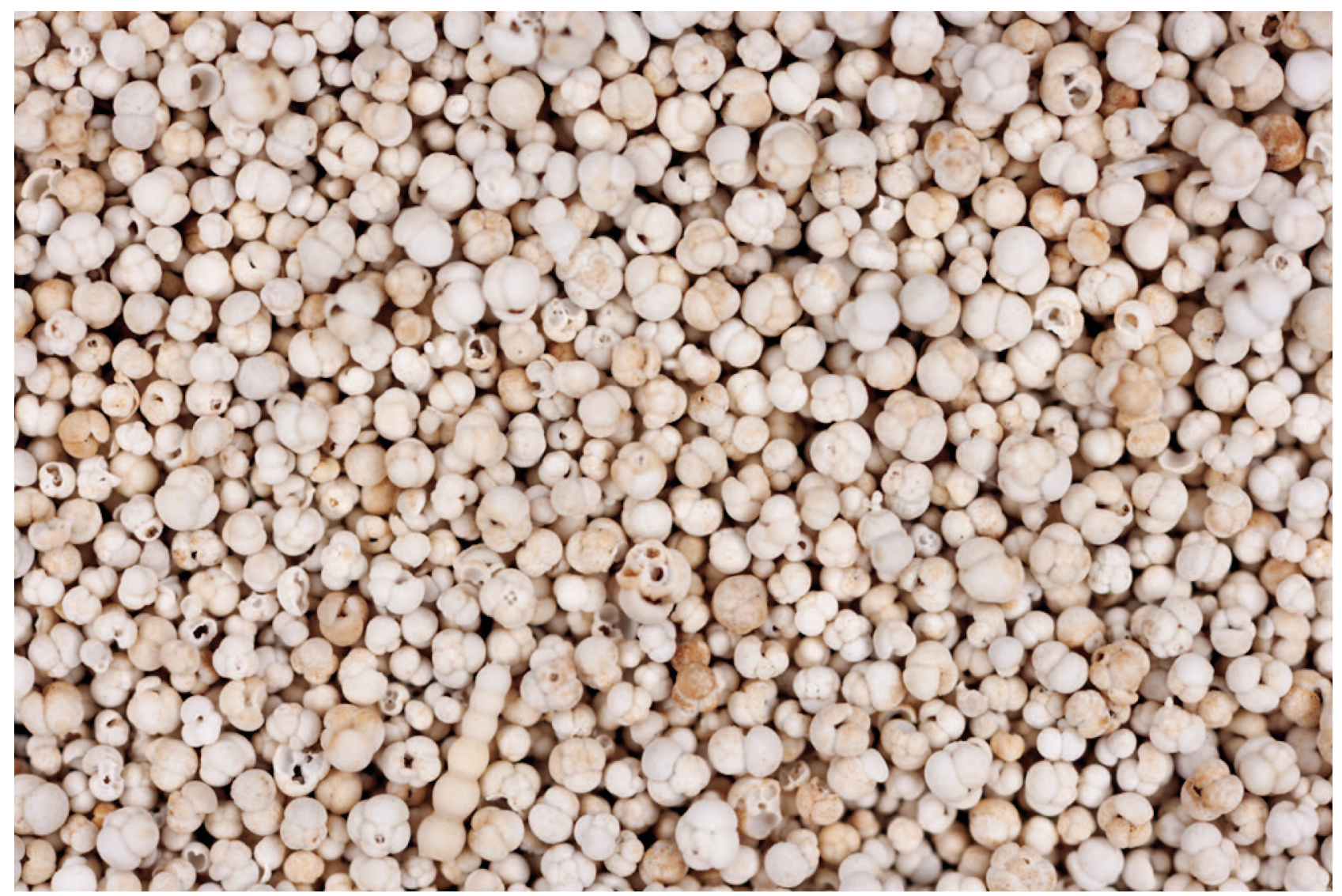


Figure F19. Plots of combined results of density and porosity measurements in sediments, Site U1367. A. Gamma ray attenuation density measured with Whole-Round Multisensor Logger and wet bulk density measured on discrete samples using the mass/volume methods (large circles). B. Grain density measured on discrete samples using the moisture and density (MAD) mass/volume methods. C. Porosity determined using MAD Method C. The upper horizontal line shows the contact between lithologic Units I and II for Holes U1367B and U1367C, the intermediate line corresponds to the contact for Hole U1367E, and the lower horizontal line corresponds to the contact in Hole U1367D.

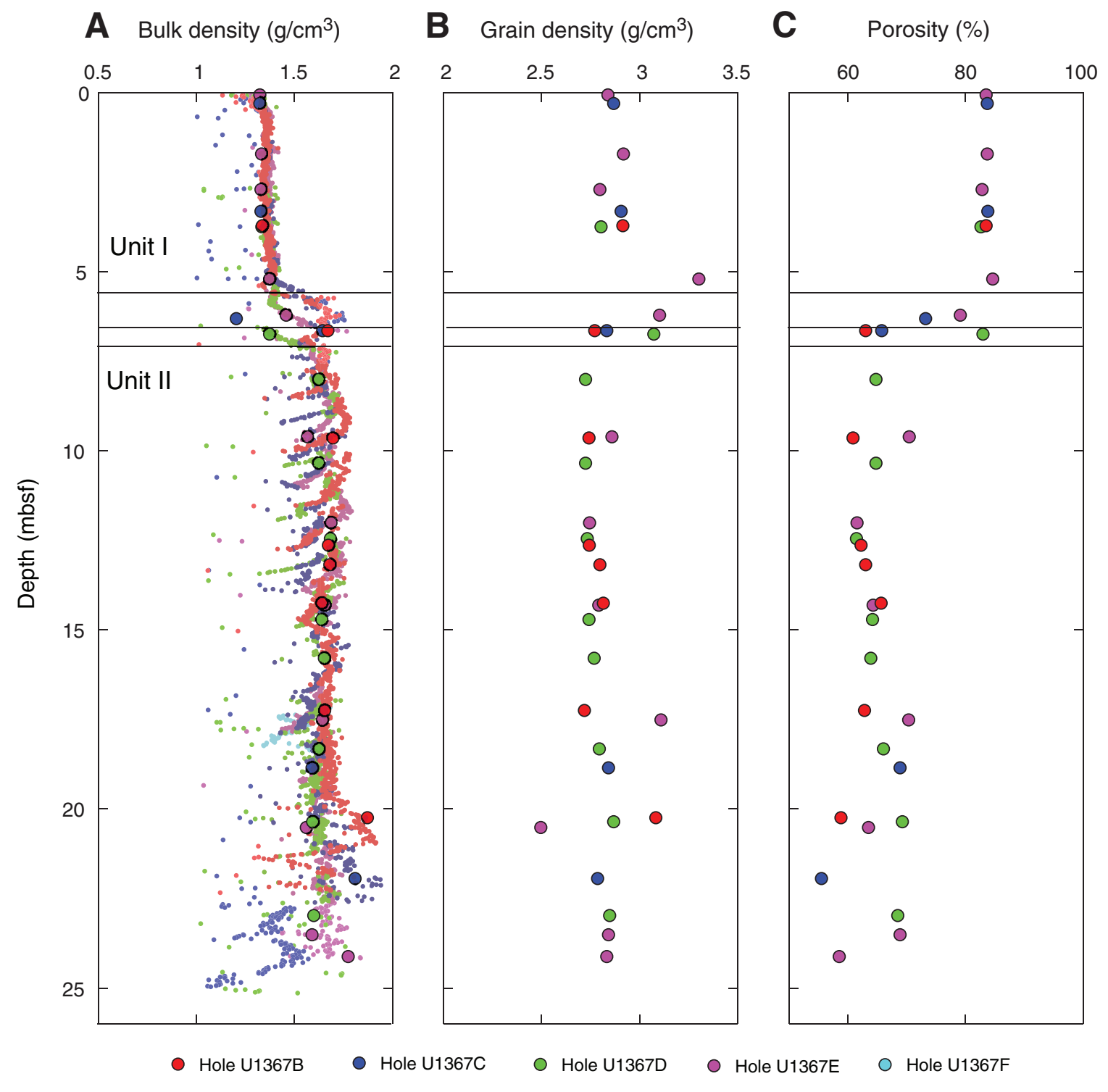


Figure F20. Plots of (A-D) magnetic susceptibility measurements made on the Whole-Round Multisensor Logger and (E-H) point magnetic susceptibility measurements made on the Section Half Multisensor Logger, Site U1367.
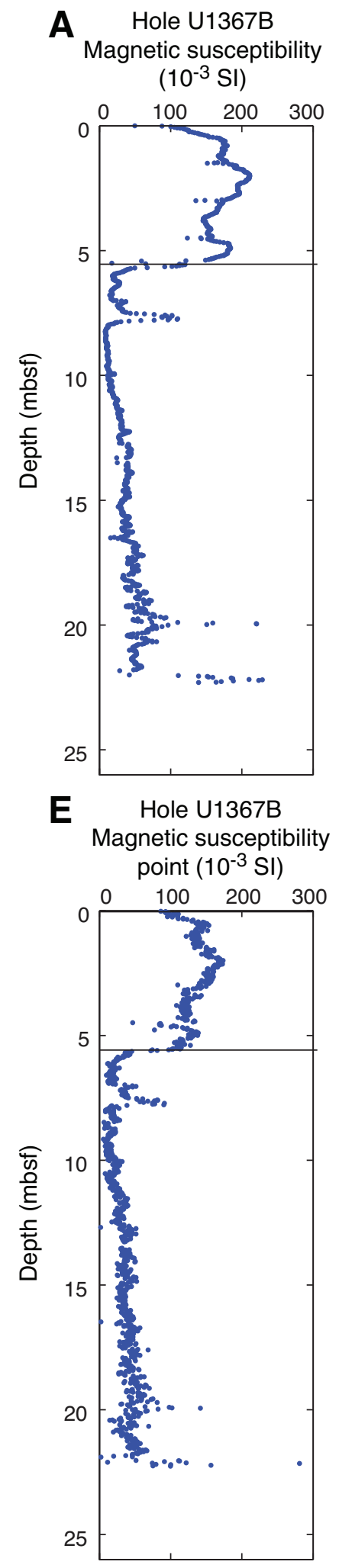

B Hole U1367C Magnetic susceptibility
$\left(10^{-3} \mathrm{SI}\right)$

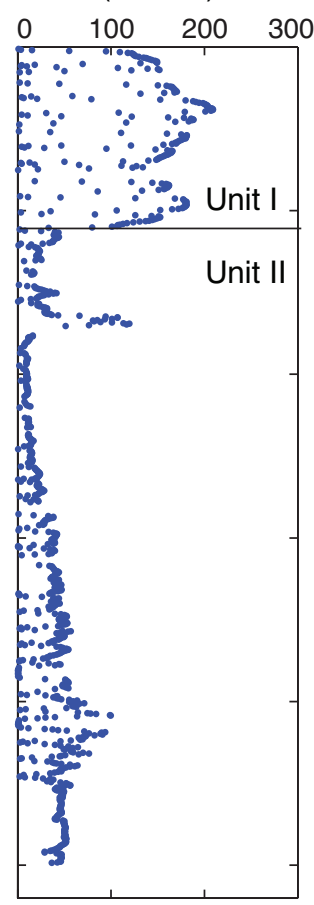

F Magnetic susceptibility
point $\left(10^{-3} \mathrm{SI}\right)$

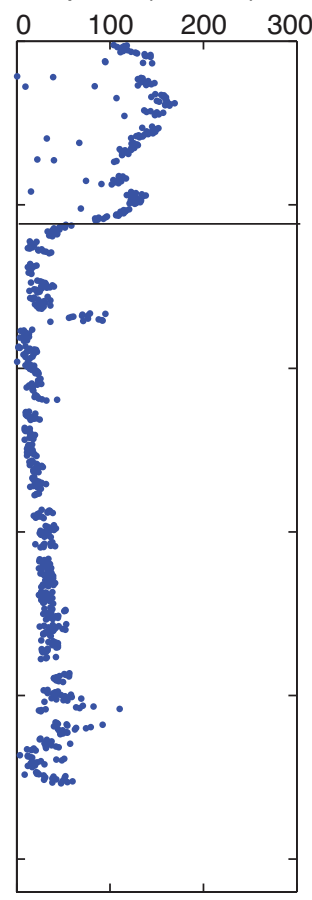

C Hole U1367D $\left(10^{-3} \mathrm{SI}\right)$

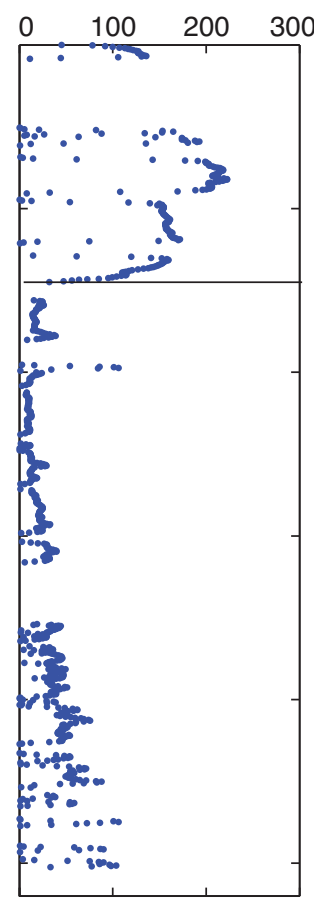

G
Magnetic susceptibility point $\left(10^{-3} \mathrm{SI}\right)$

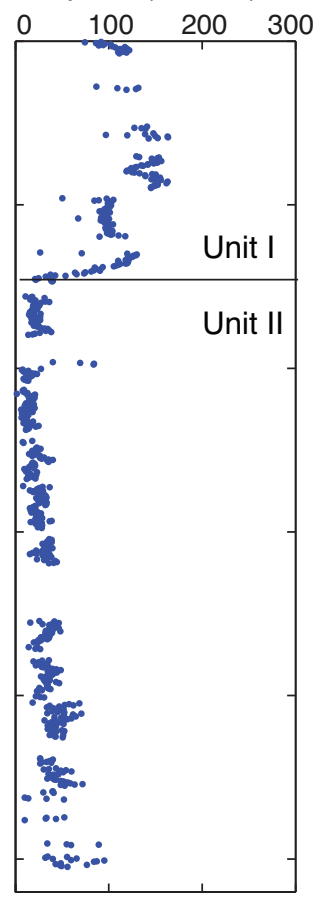

D Hole U1367E Magnetic susceptibility $\left(10^{-3} \mathrm{SI}\right)$

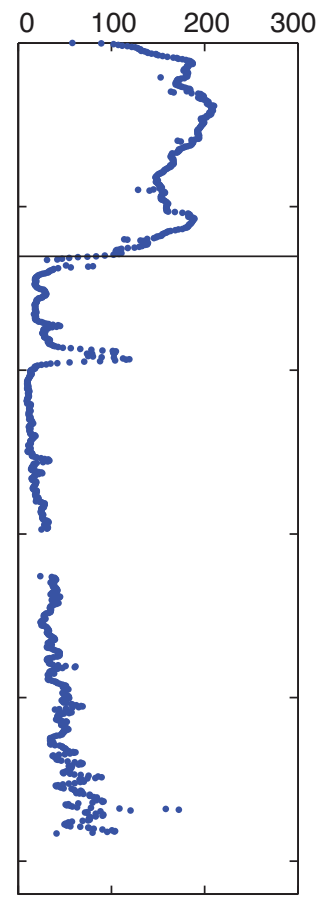

H Hole U1367E Magnetic susceptibility point $\left(10^{-3} \mathrm{SI}\right)$

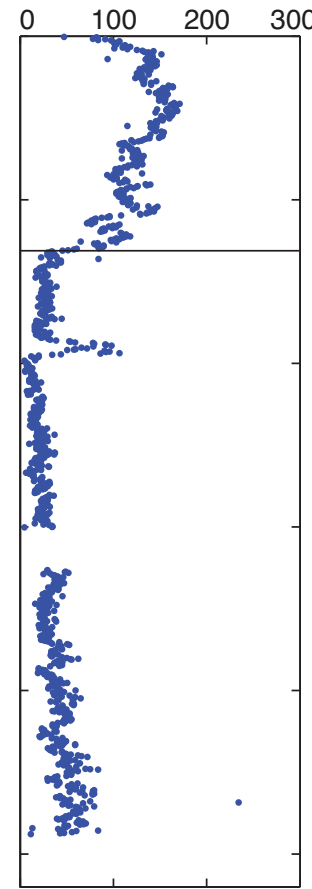


Figure F21. A. Plots of natural gamma radiation (NGR) as a function depth, Site U1367. B. Same data as A at an expanded scale.
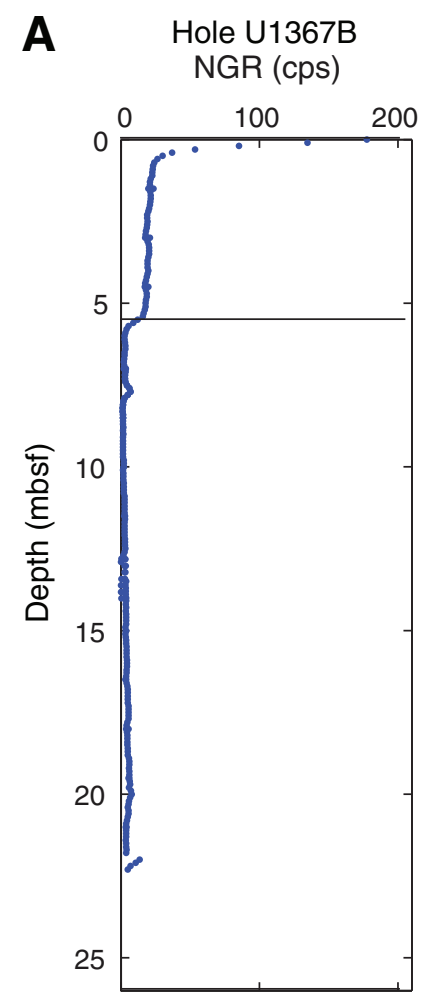

B

$$
\begin{gathered}
\text { Hole U1367B } \\
\text { NGR (cps) }
\end{gathered}
$$

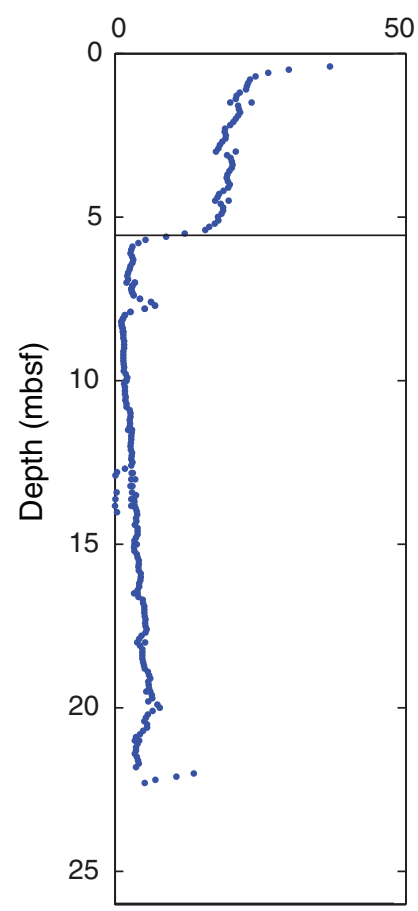

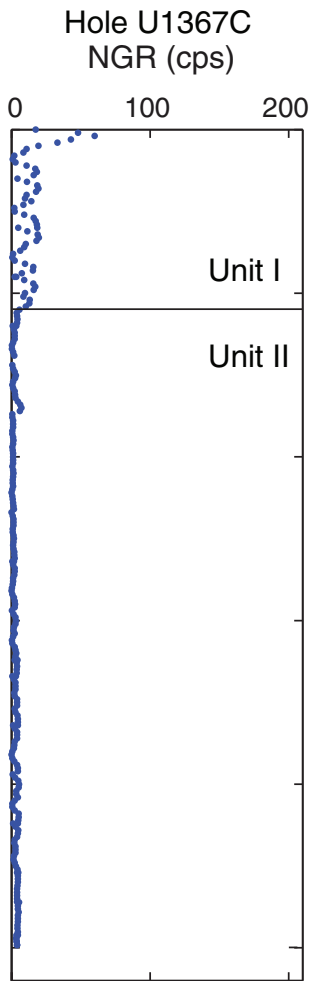

$$
\begin{gathered}
\text { Hole U1367C } \\
\text { NGR (cps) }
\end{gathered}
$$

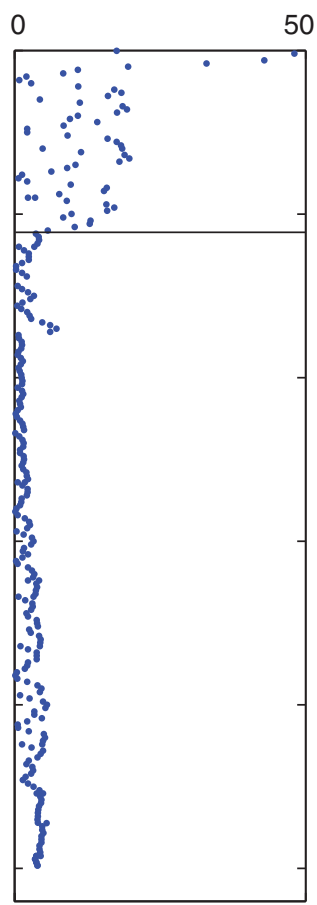

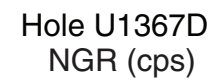

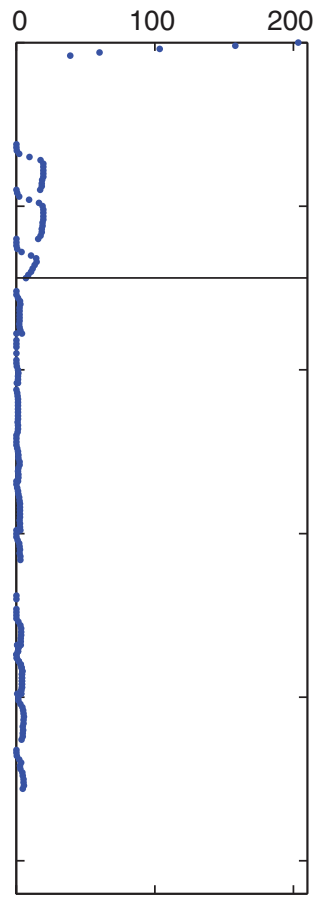

Hole U1367D

NGR (cps)

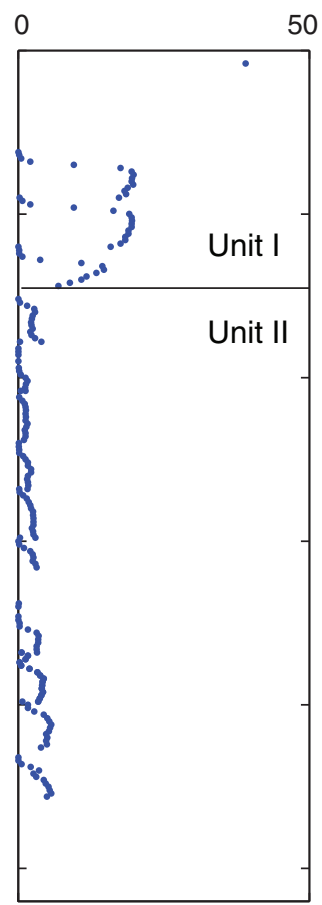

Hole U1367E

NGR (cps)

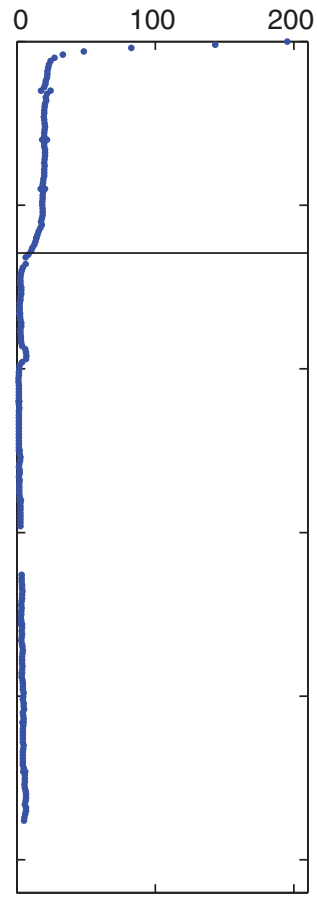

Hole U1367E

NGR (cps)

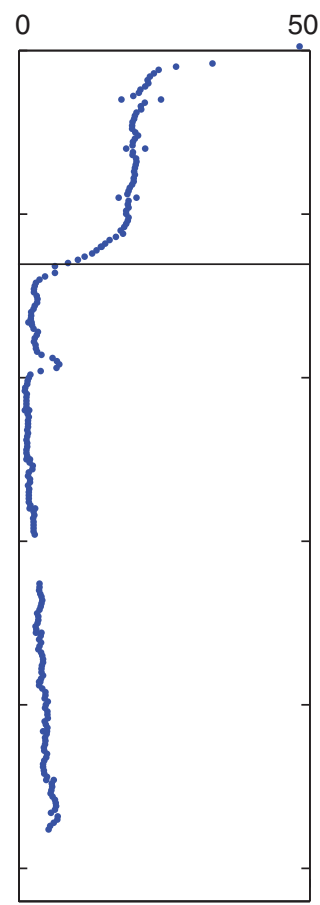


Figure F22. A. Plots of compressional wave velocity measured with Whole-Round Multisensor Logger, Site U1367. Red circles indicate discrete measurements of $P$-wave velocity along $x$-axis. Red circles $=$ discrete measurements on the $x$-axis. B. Histogram of sediment $P$-wave velocity from Holes U1367B-U1367E.

A
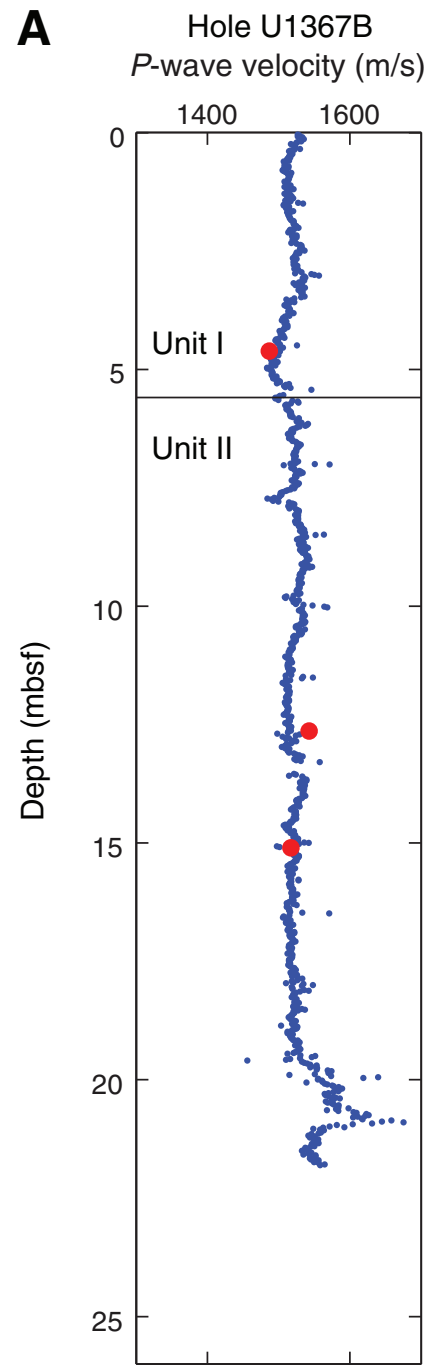

Hole U1367C

$P$-wave velocity $(\mathrm{m} / \mathrm{s})$

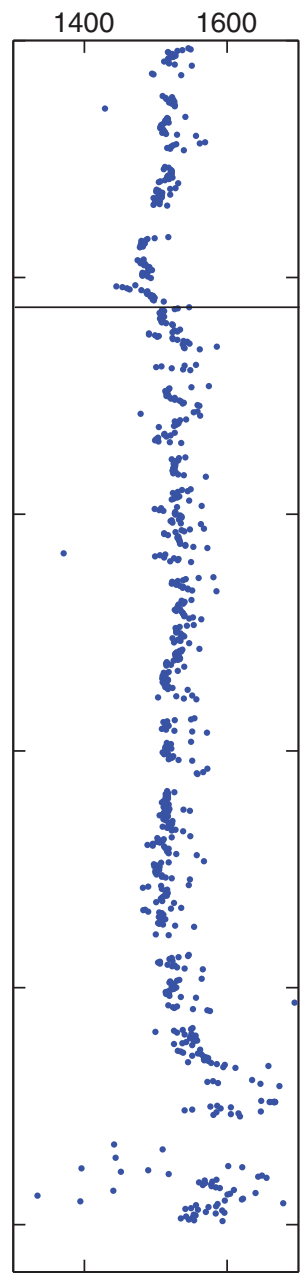

Hole U1367D

$P$-wave velocity $(\mathrm{m} / \mathrm{s})$

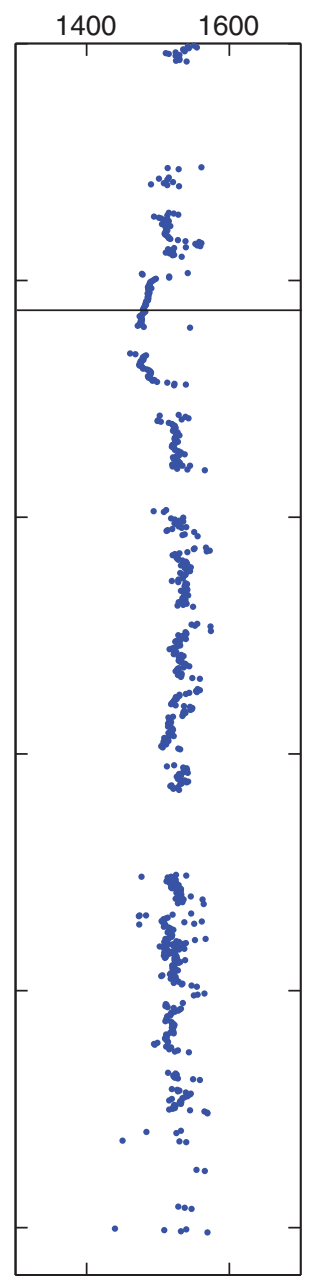

Hole U1367E

$P$-wave velocity $(\mathrm{m} / \mathrm{s})$

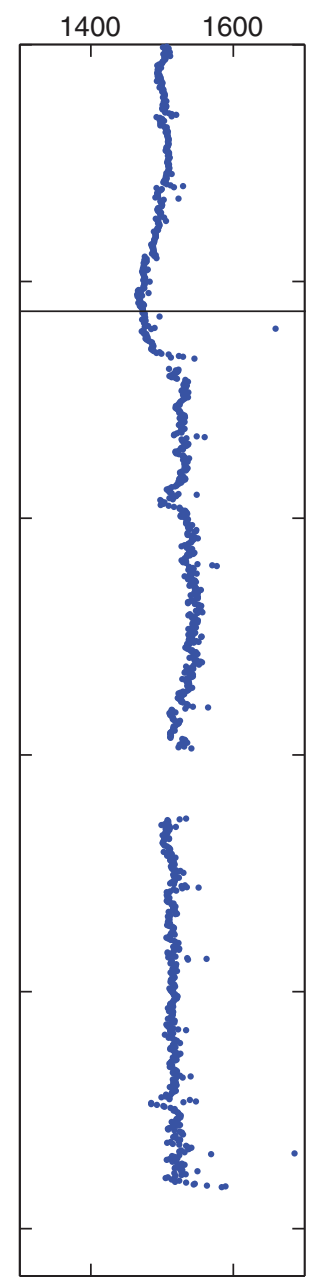

B

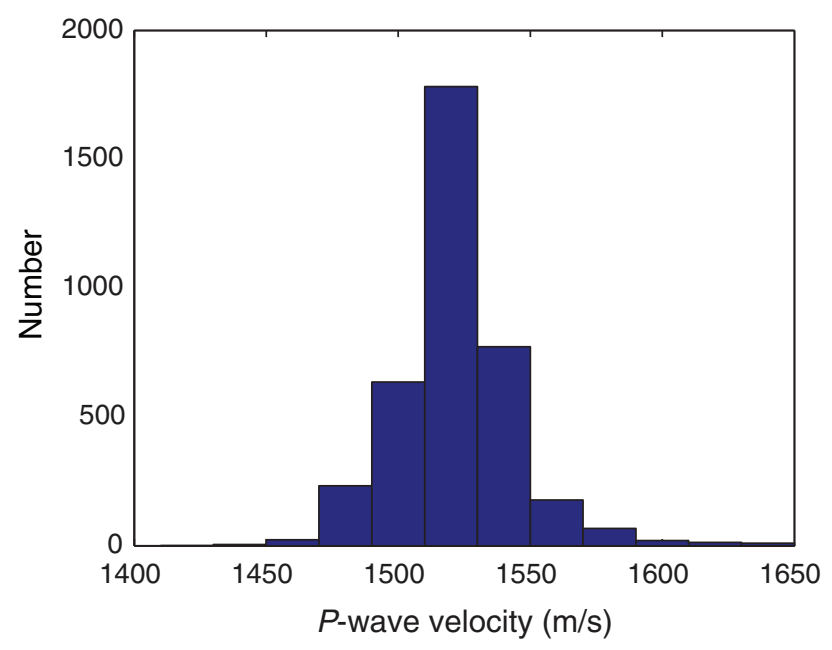


Figure F23. Plot of electrical conductivity measured on surface seawater standard, Site U1367. Line shows best linear fit to data. The best fitting slope and $y$-intercept are $-8.2 \times 10^{-4} \mathrm{mS} / \mathrm{m} /$ measurement number and 49.81 $\mathrm{mS} / \mathrm{m}$, respectively.

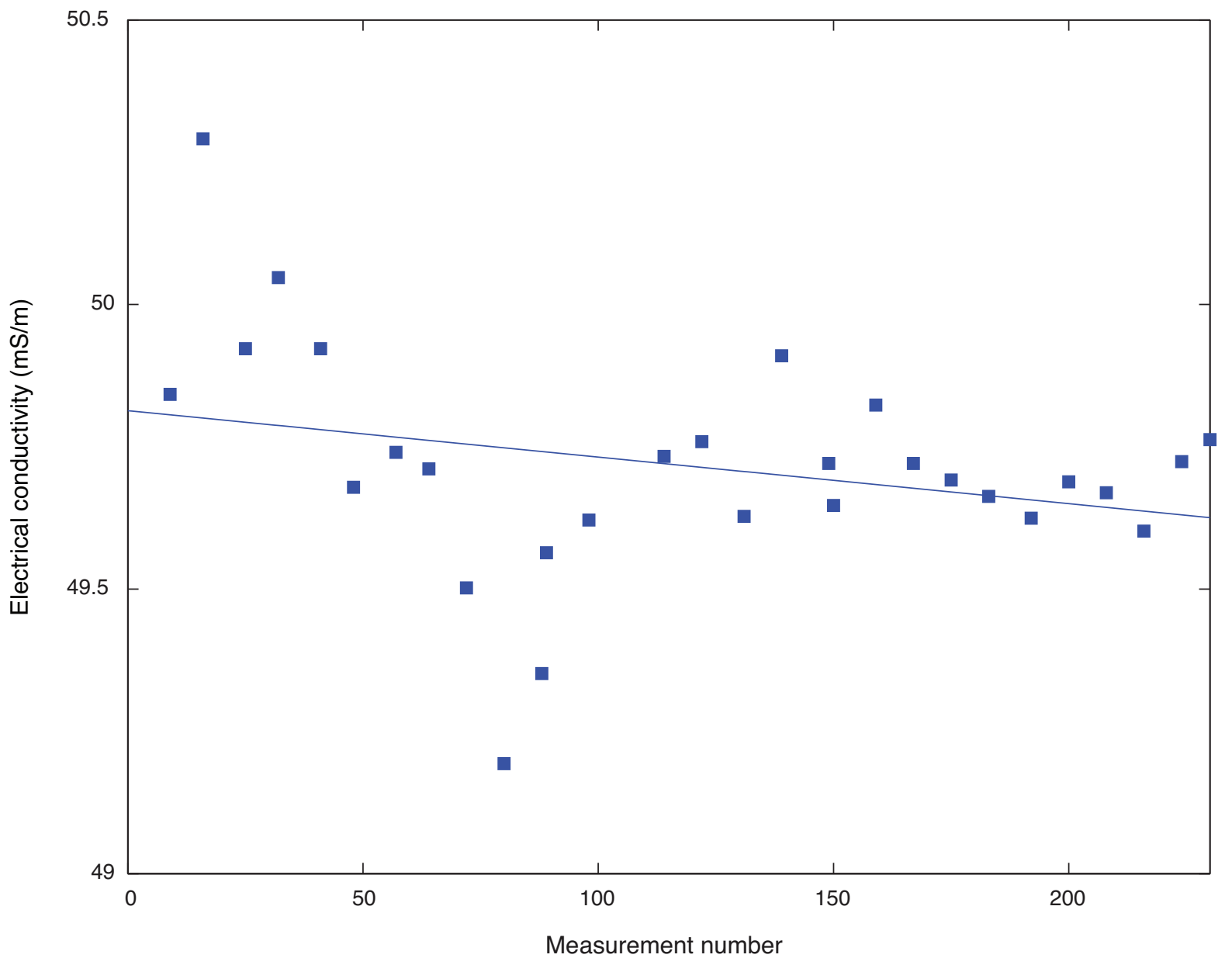


Figure F24. Plot of formation factor as function of depth, Hole U1367B.

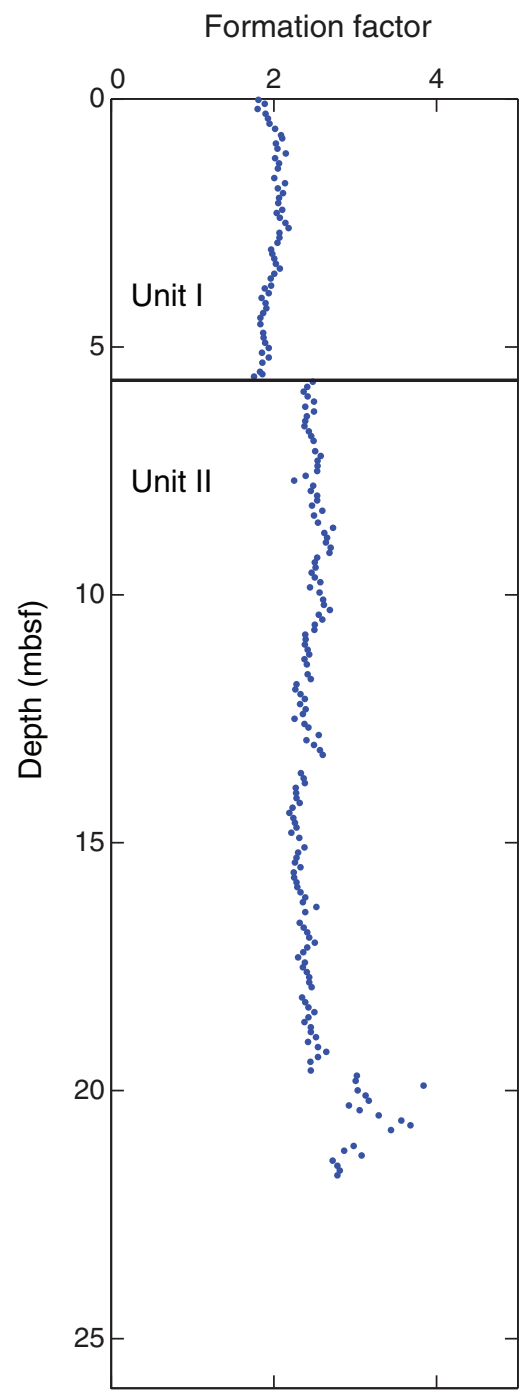


Figure F25. Plot of full-space measurement thermal conductivity data, Site U1367. Open circles are unreliable because of likely fluid convection within the sample. Red circles show values collected during the KNOX-02RR site survey. Upper horizontal line represents the contact between lithologic Units I and II for Holes U1367B and U1367C, intermediate line corresponds to the contact for Hole U1367E, and the lower horizontal line corresponds to the contact in Hole U1367D.

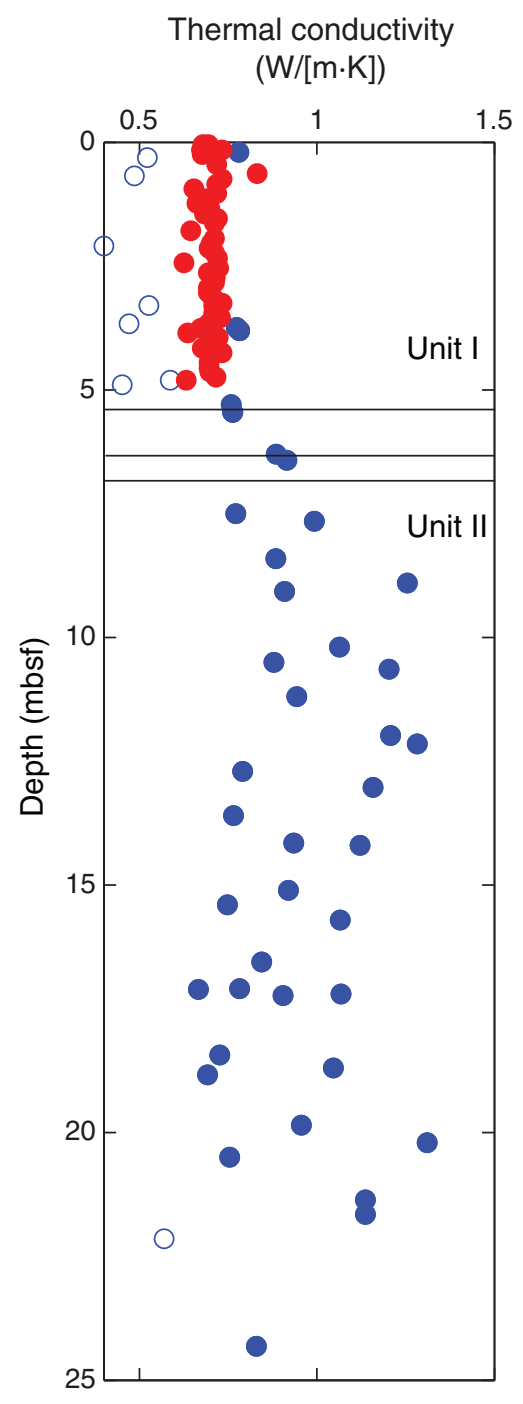


Figure F26. Plots of color spectrometry L* values, Site U1367.
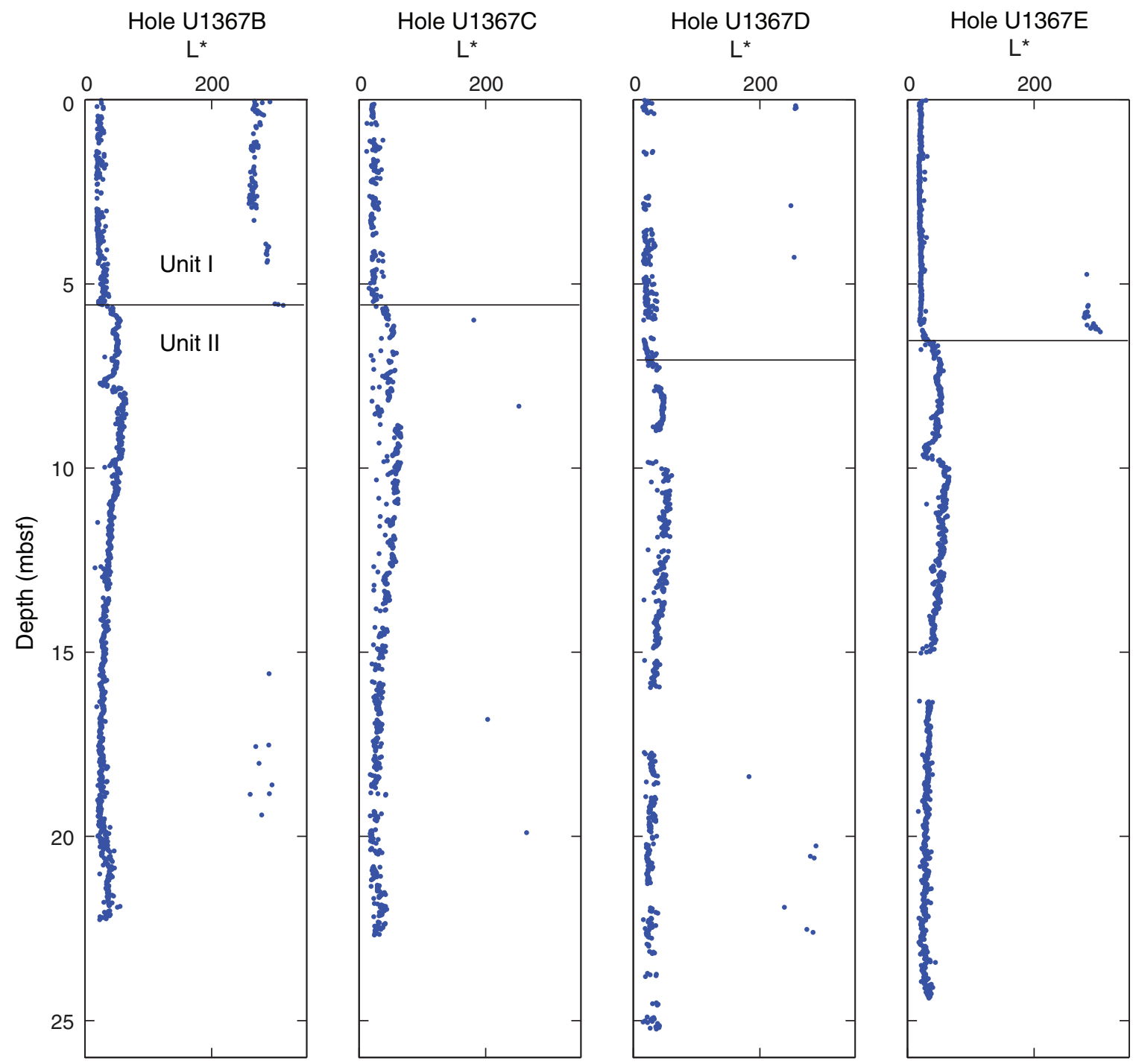
Figure F27. Plots of color spectrometry a* values, Site U1367.

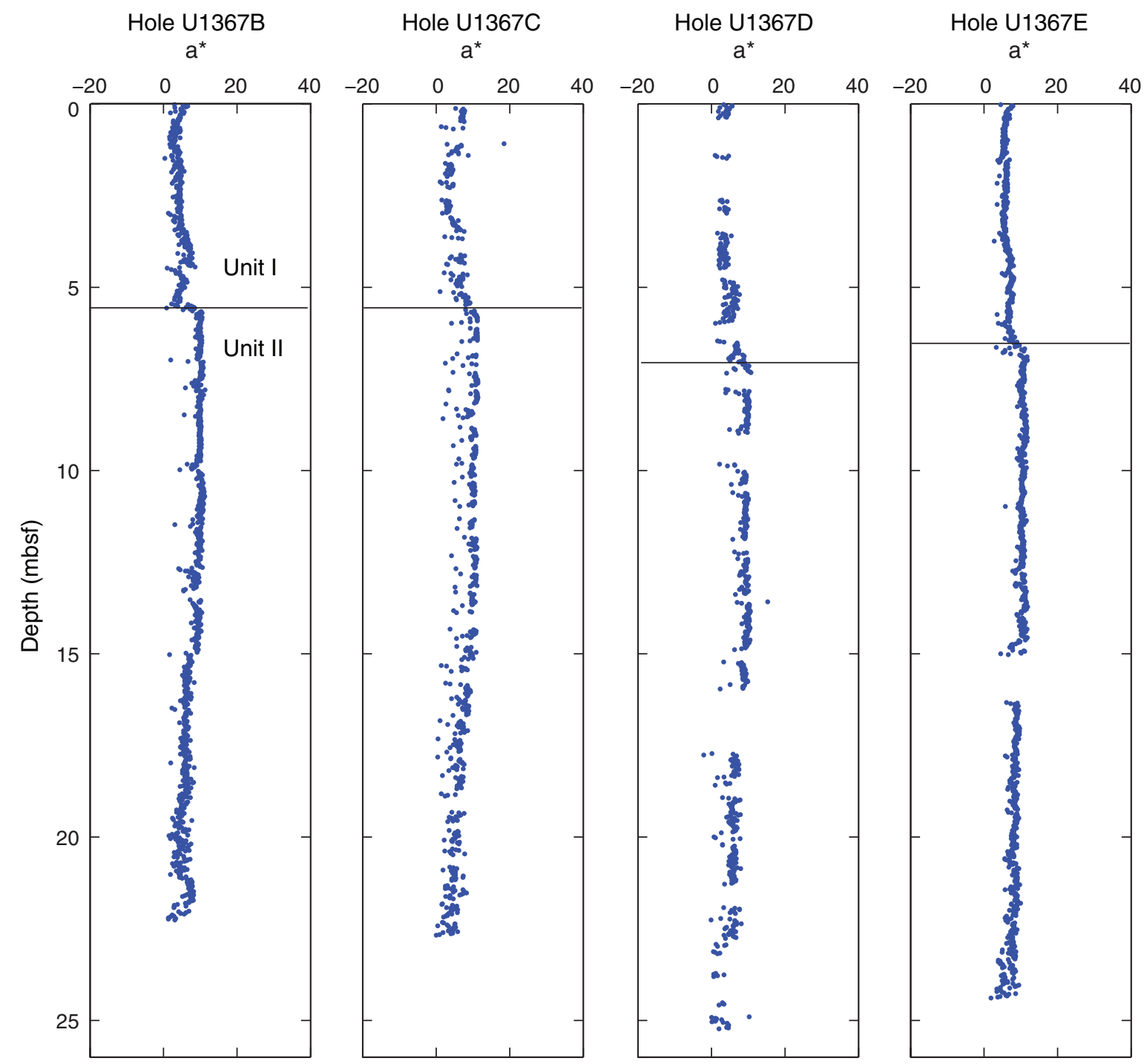


Figure F28. Plots of color spectrometry b* values, Site U1367.

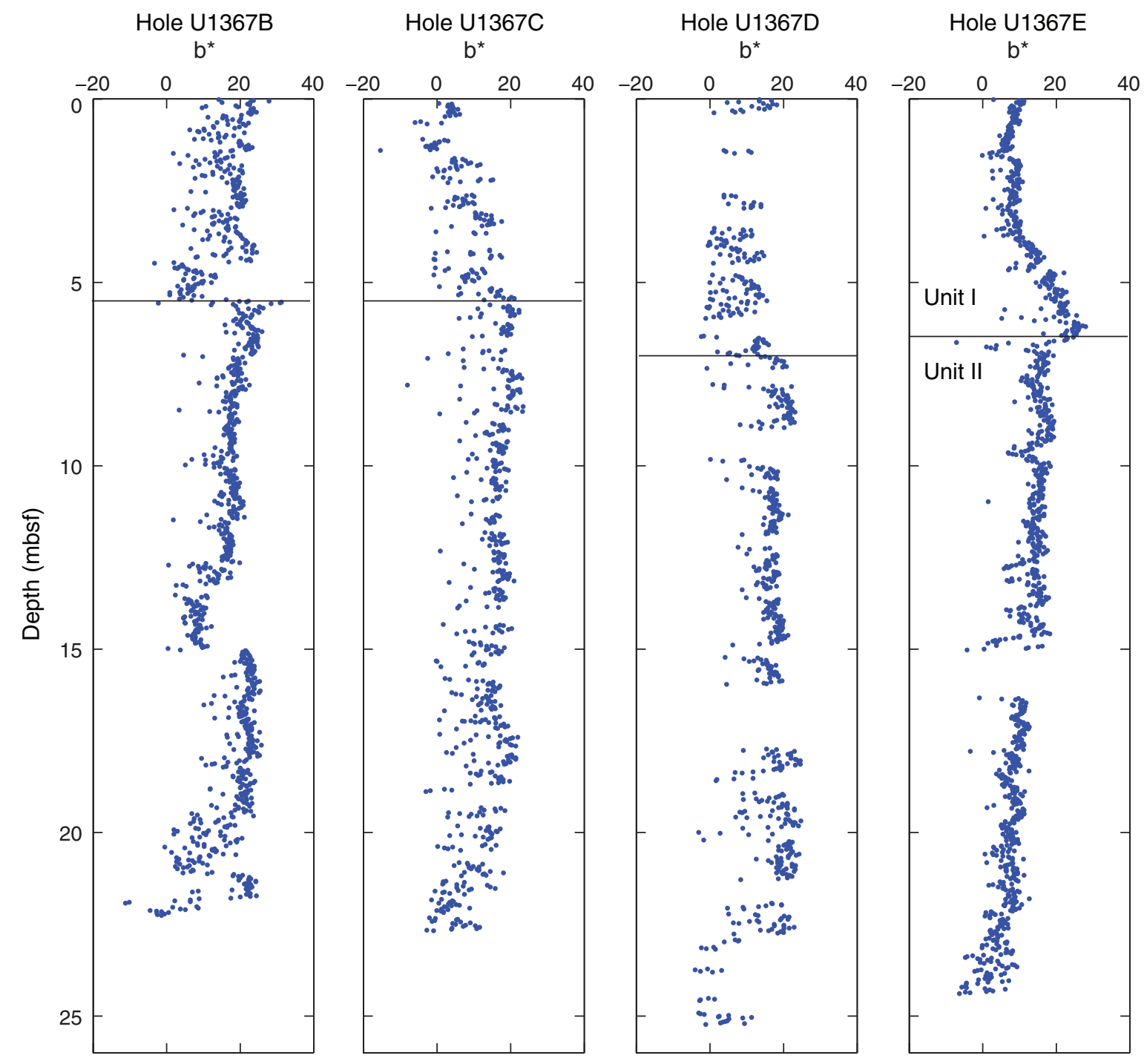


Figure F29. Summary of magnetic susceptibility and paleomagnetic intensity, Hole U1367B. Gray = measurement before demagnetization, red = measurement after $20 \mathrm{mT}$ AF demagnetization step (inclination and intensity), blue $=$ declination measurements, green $=$ magnetic susceptibility data. Black squares $=$ magnetic directions of discrete cube samples from the working-half cores.

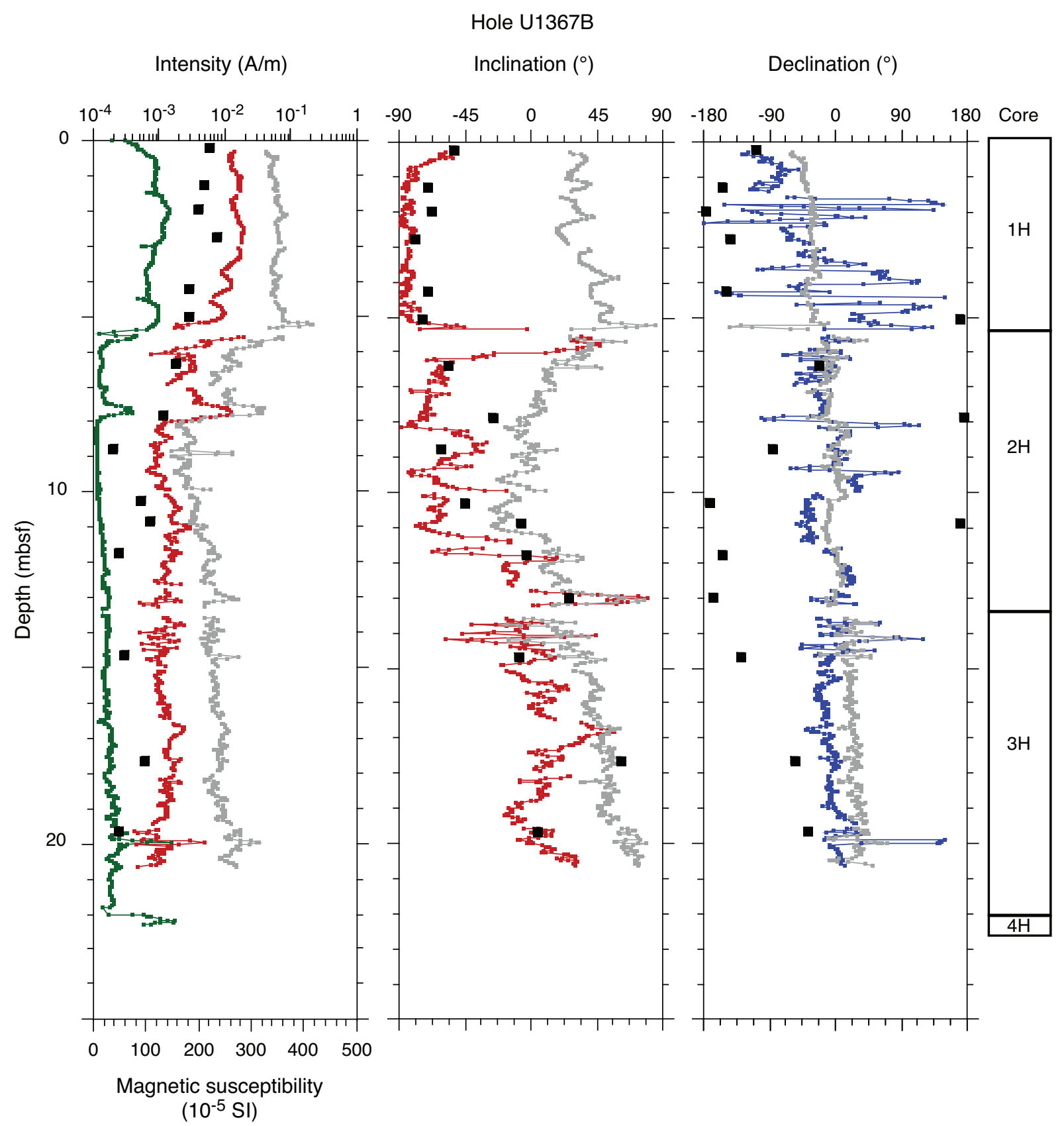


Figure F30. Summary of magnetic susceptibility and paleomagnetic results, Hole U1367C. Gray = measurement before demagnetization, red = measurement after $20 \mathrm{mT}$ AF demagnetization step (inclination and intensity), blue $=$ declination measurements, green $=$ magnetic susceptibility data .

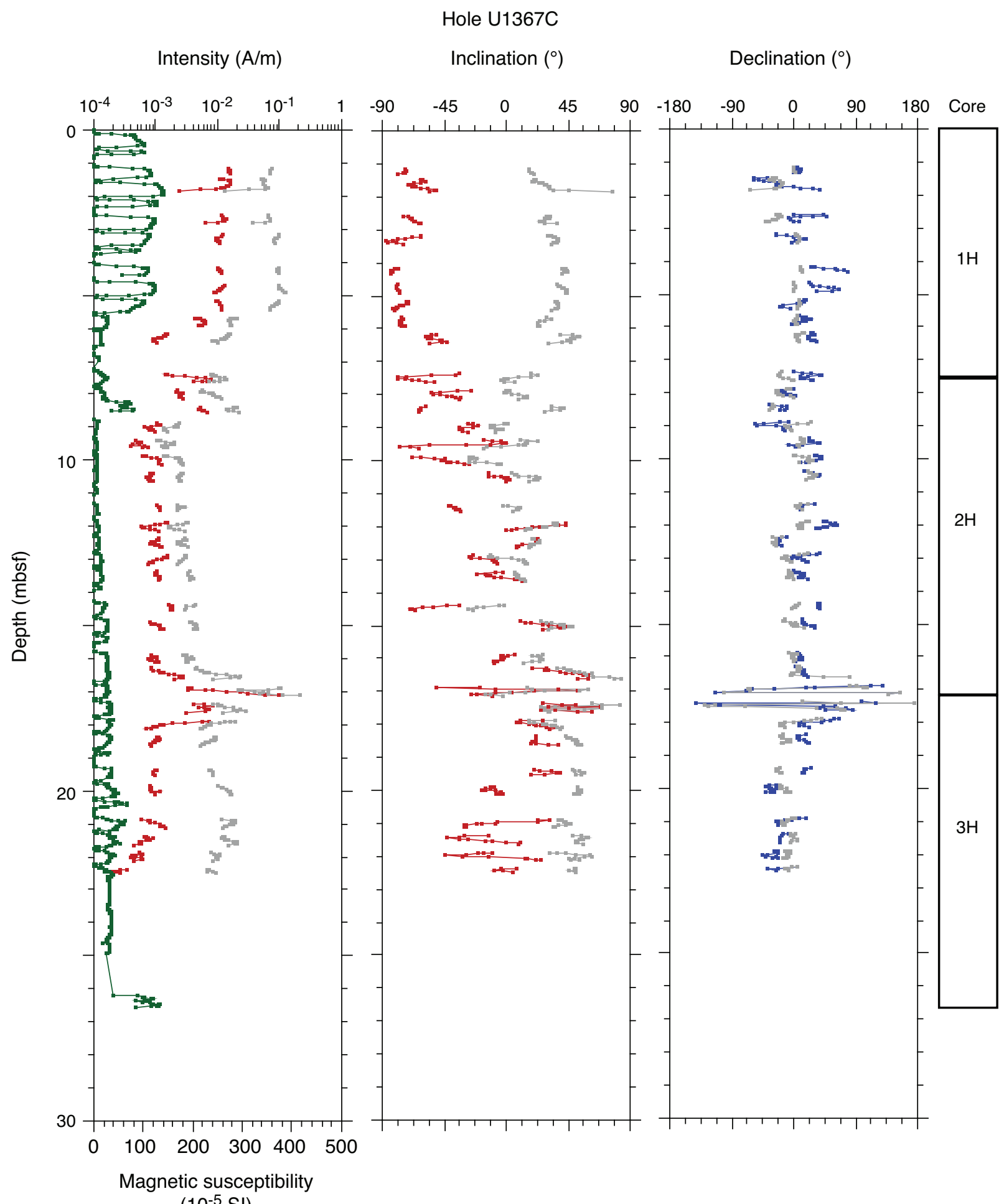


Figure F31. Summary of magnetic susceptibility and paleomagnetic results, Hole U1367D. Gray = measurement before demagnetization, red = measurement after $20 \mathrm{mT}$ AF demagnetization step (inclination and intensity), blue $=$ declination measurements, green $=$ magnetic susceptibility data .

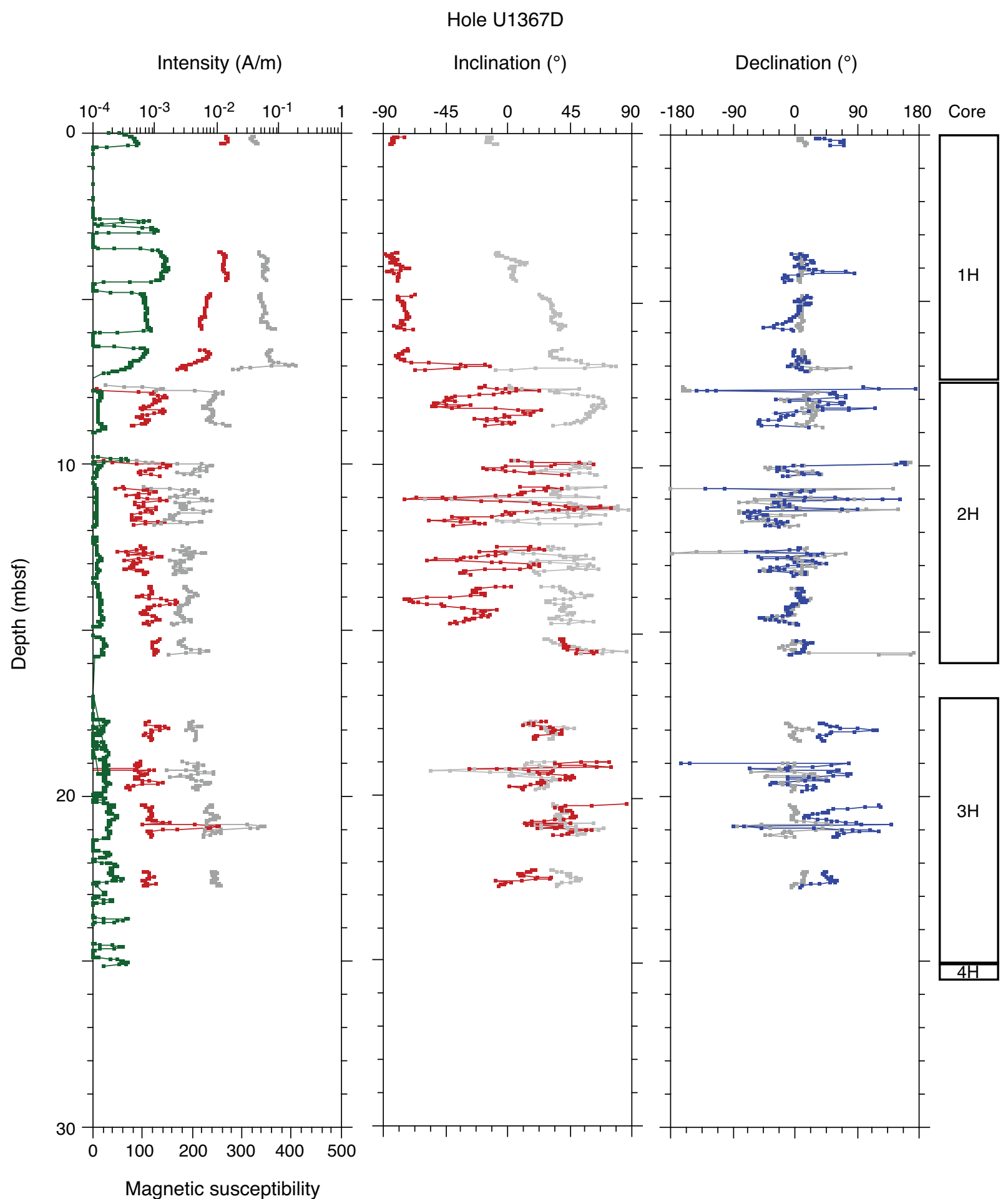

$\left(10^{-5} \mathrm{SI}\right)$ 
Figure F32. Summary of magnetic susceptibility and paleomagnetic results, Hole U1367E. Gray = measurement before demagnetization, red = measurement after $20 \mathrm{mT}$ AF demagnetization step (inclination and intensity), blue $=$ declination measurements, green $=$ magnetic susceptibility data .

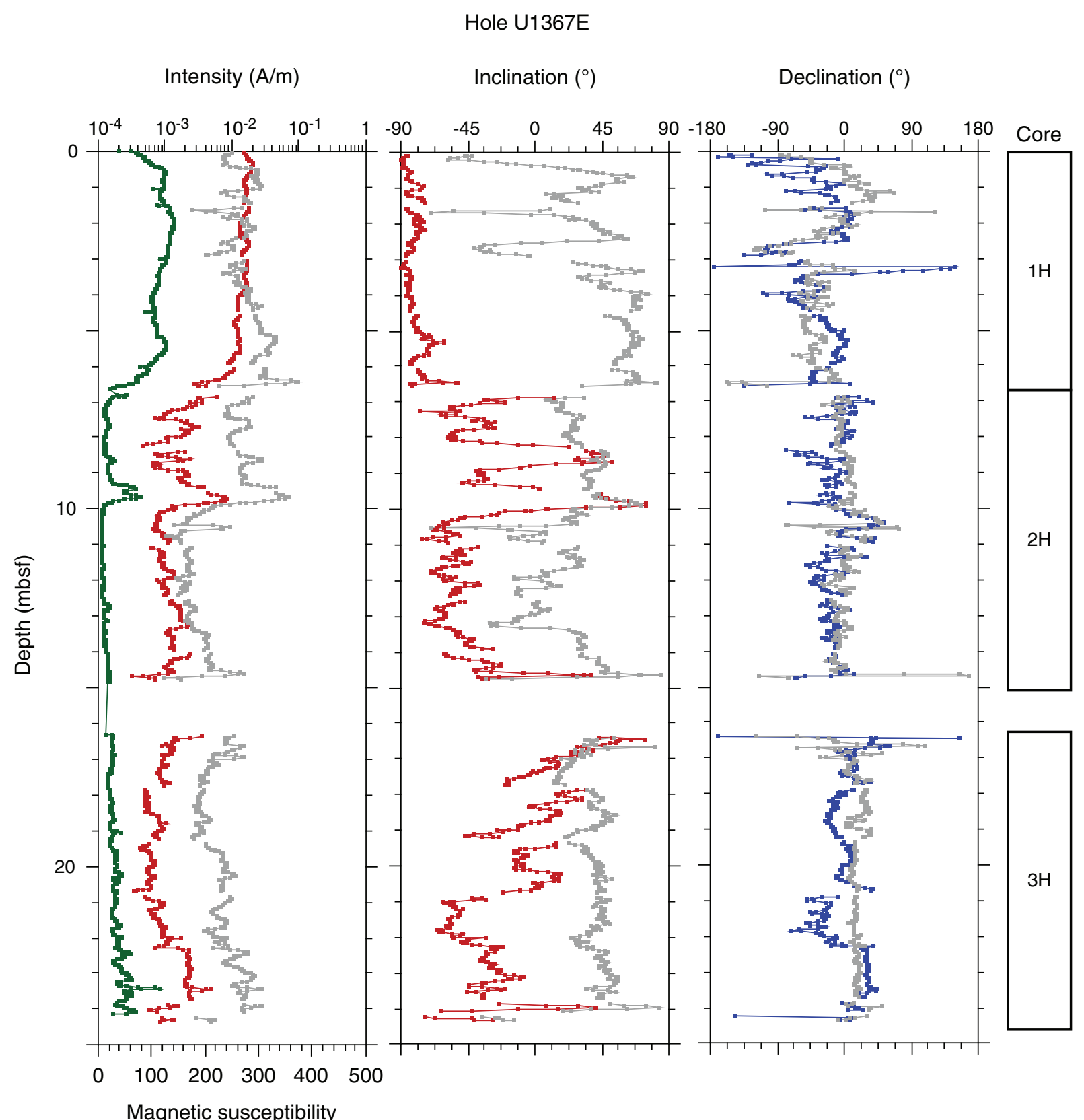

$\left(10^{-5} \mathrm{SI}\right)$ 
Figure F33. Results of hole-to-hole correlation using magnetic susceptibility data (green) from Holes U1367B and U1367E. Dashed black lines indicate correlation points between holes. Gray $=$ measurement before demagnetization, red $=$ measurement after $20 \mathrm{mT}$ AF demagnetization step. Black squares $=$ magnetic directions of discrete cube samples from the working-half cores.

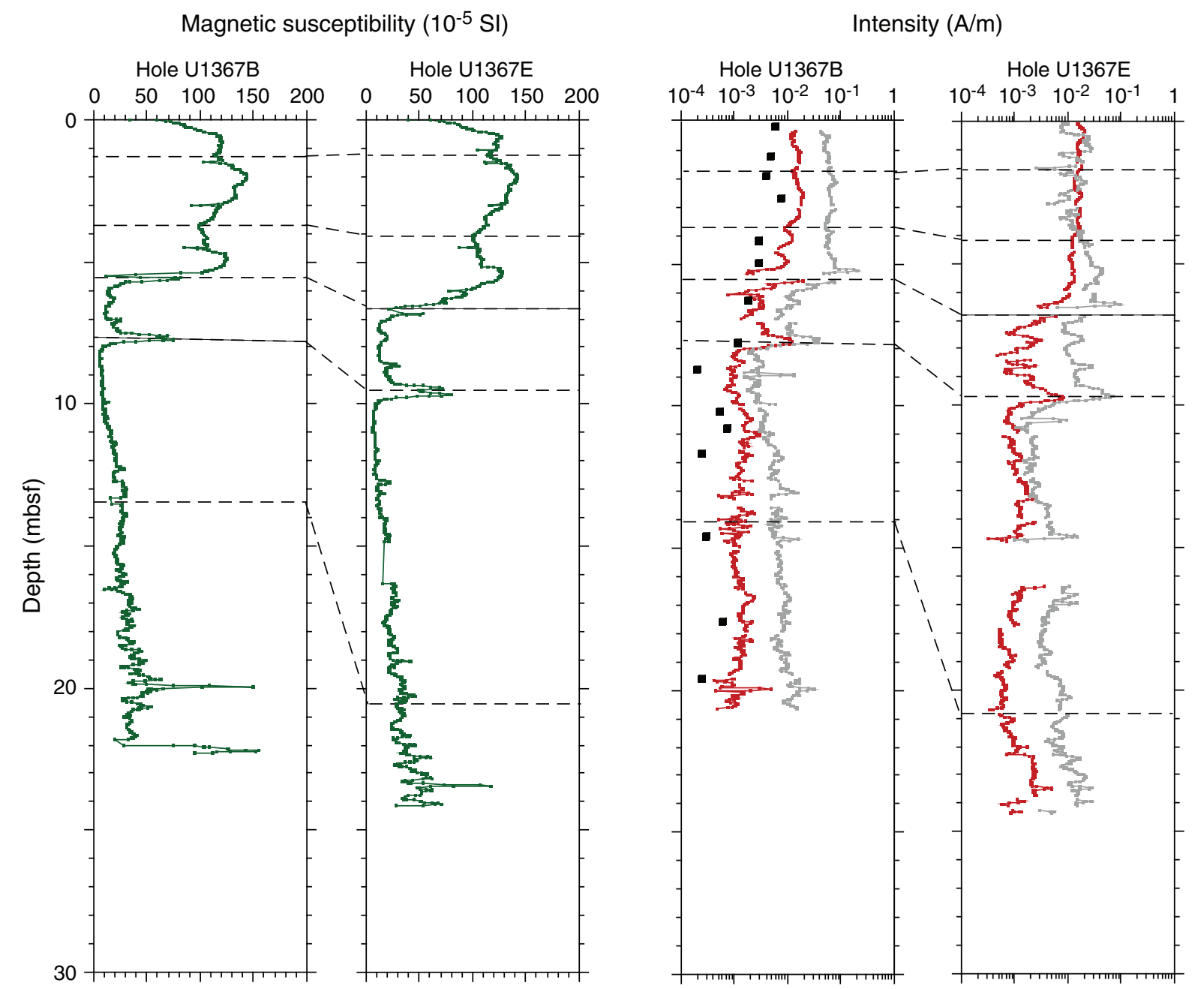


Figure F34. Correlation of the polarity records between Holes U1367B and U1367E. Inclination (red) and declination (blue) data are after the $20 \mathrm{mT}$ AF demagnetization step. Gray = measurement before demagnetization. Black lines indicate correlation using the magnetic susceptibility data between holes. Black squares = magnetic directions of discrete cube samples from the working-half cores.

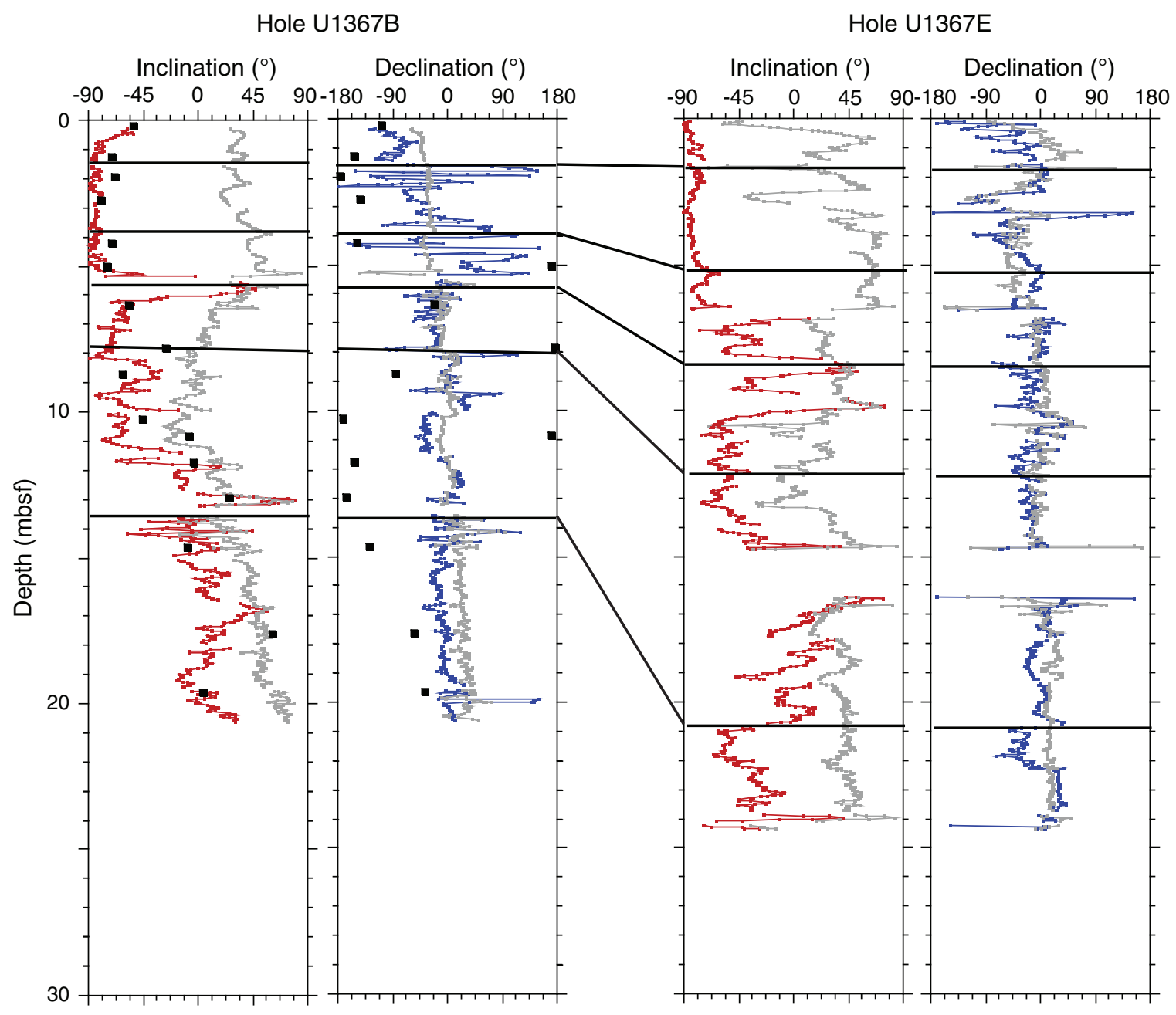


Figure F35. Plots of combined dissolved oxygen optode and electrode data, Site U1367. A. Holes U1367B, U1367E, and U1367C. B. Holes U1367B, U1367C, and U1367E in the uppermost $10 \mathrm{~m}$ of sediment.

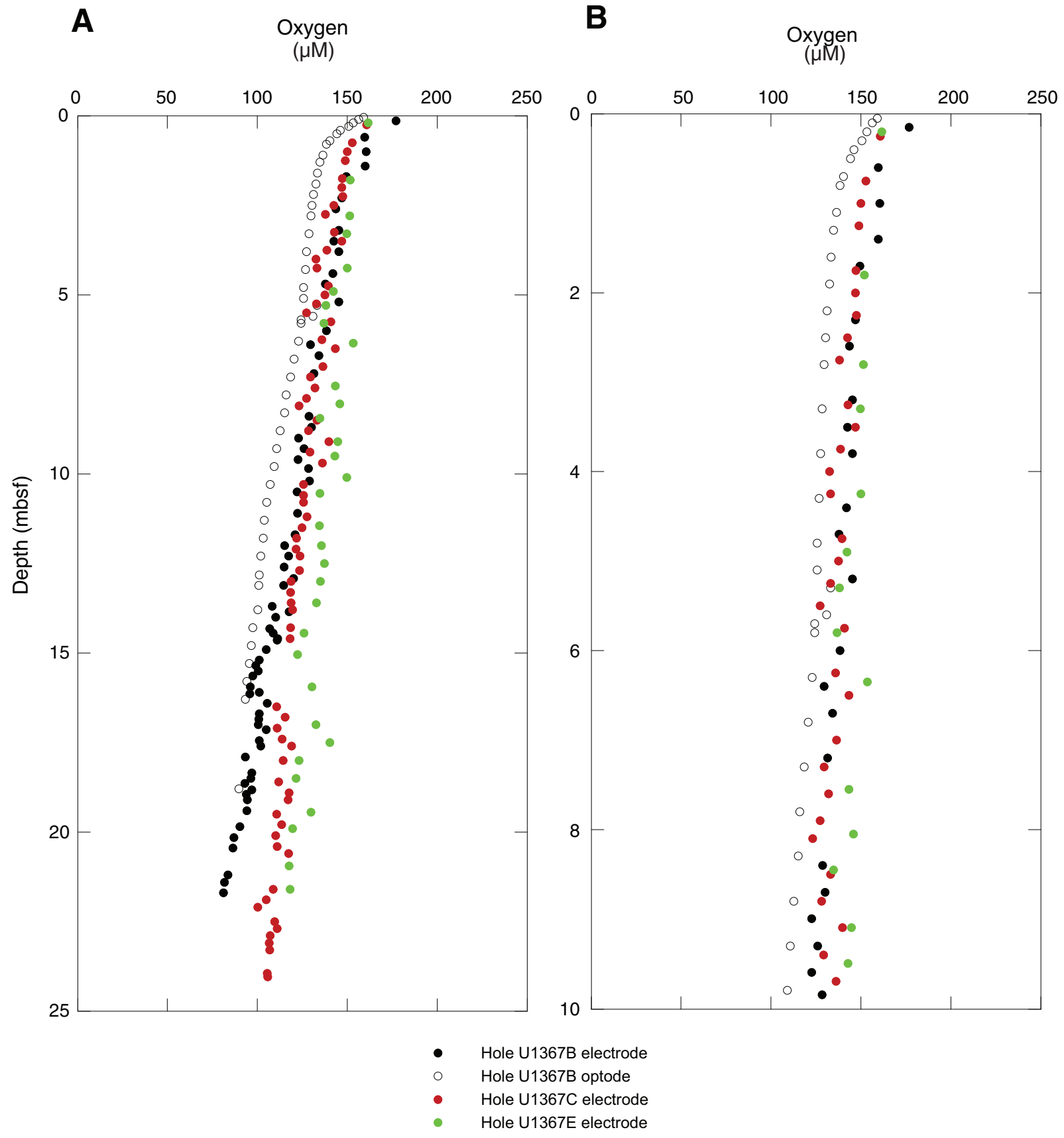


Figure F36. Plot of dissolved hydrogen concentrations, Holes U1367C and U1367D.

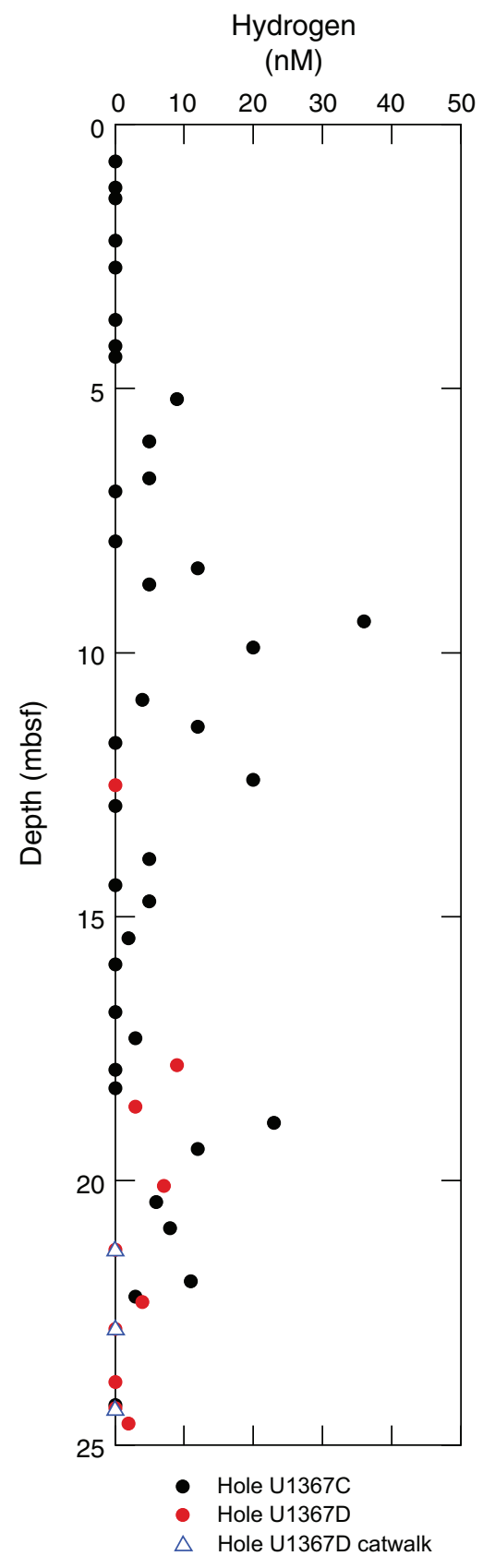


Figure F37. Plots of dissolved interstitial water constituents, Site U1367. IC = ion chromatography, ICP = inductively coupled plasma-atomic emission spectroscopy. A. Nitrate. B. Phosphate. C. Silicate. D. Alkalinity. E. Dissolved inorganic carbon (DIC). (Continued on the next two pages.)

A

Nitrate
$(\mu \mathrm{M})$

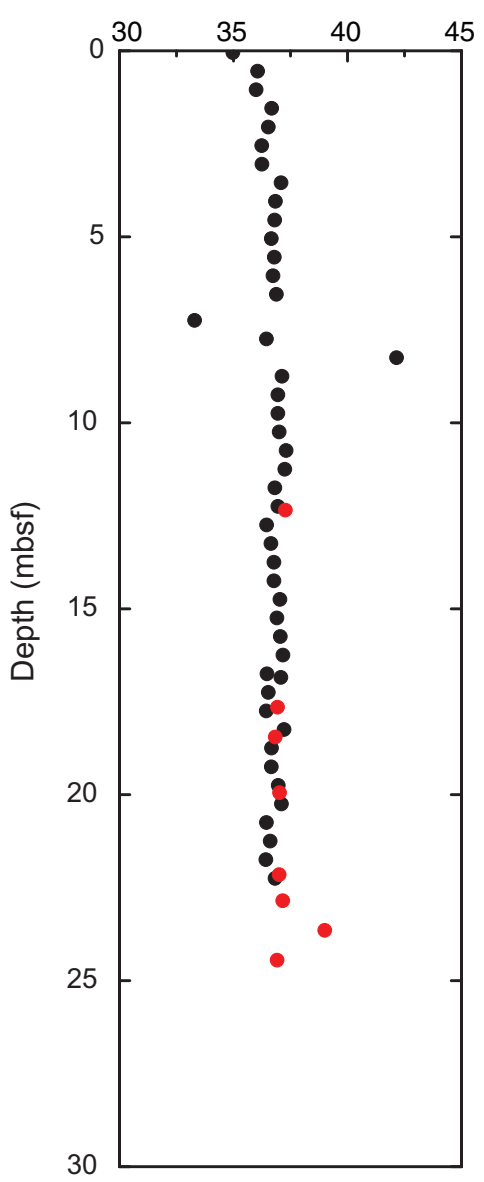

B

Phosphate

$(\mu \mathrm{M})$

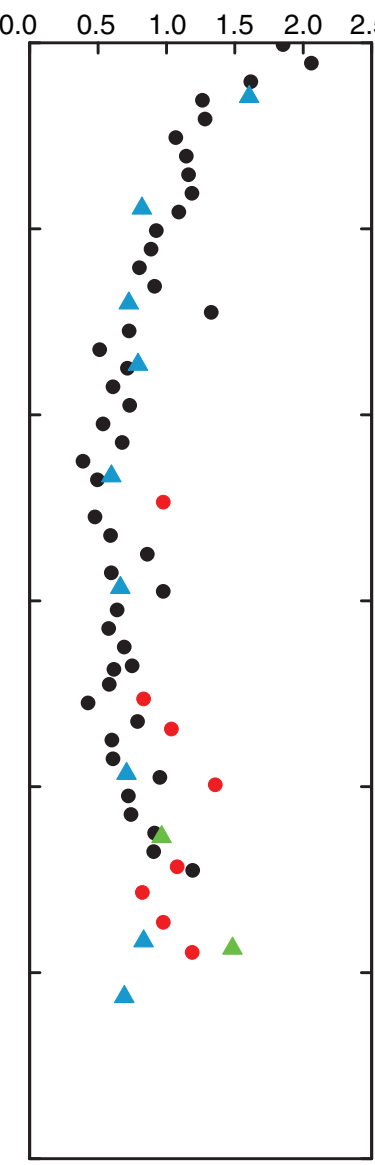

C

Silicate
$(\mu \mathrm{M})$

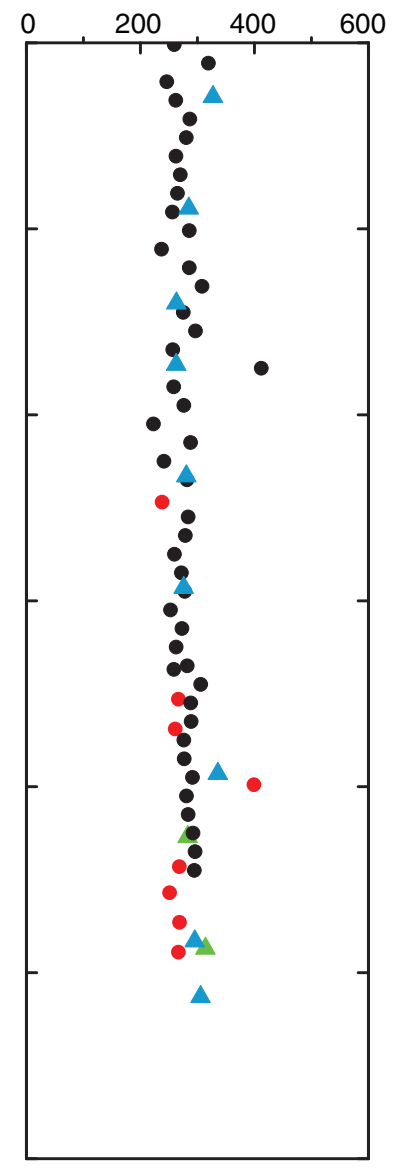

$0 \quad 200 \quad 400,600$

- Hole U1367C

Hole U1367C catwalk

- Hole U1367D

- Hole U1367D catwalk
D

Alkalinity

(mM)

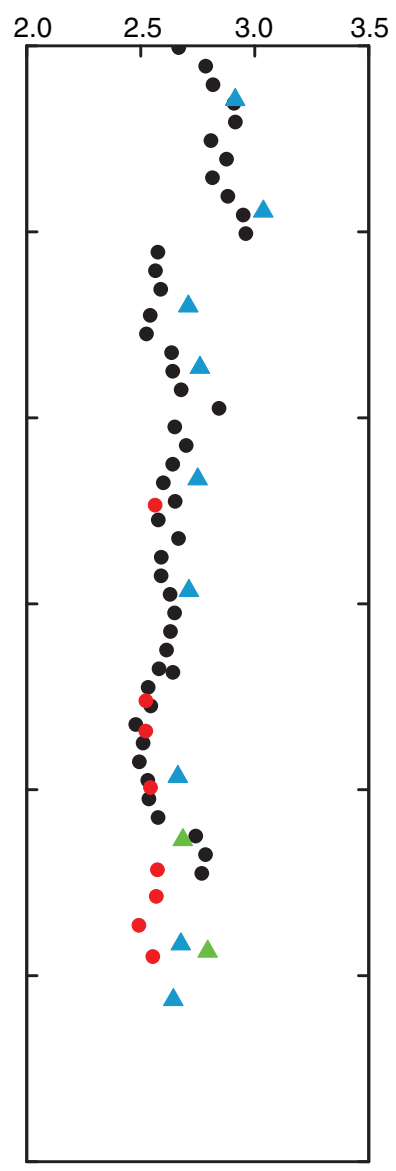

E

DIC
(mM)

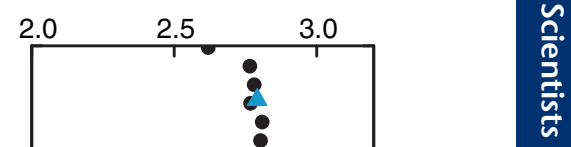


Figure F37(continued). F. Sulfate G. Sulfate anomaly H. Chloride. I. Calcium. J. Magnesium (Continued on the next page.)

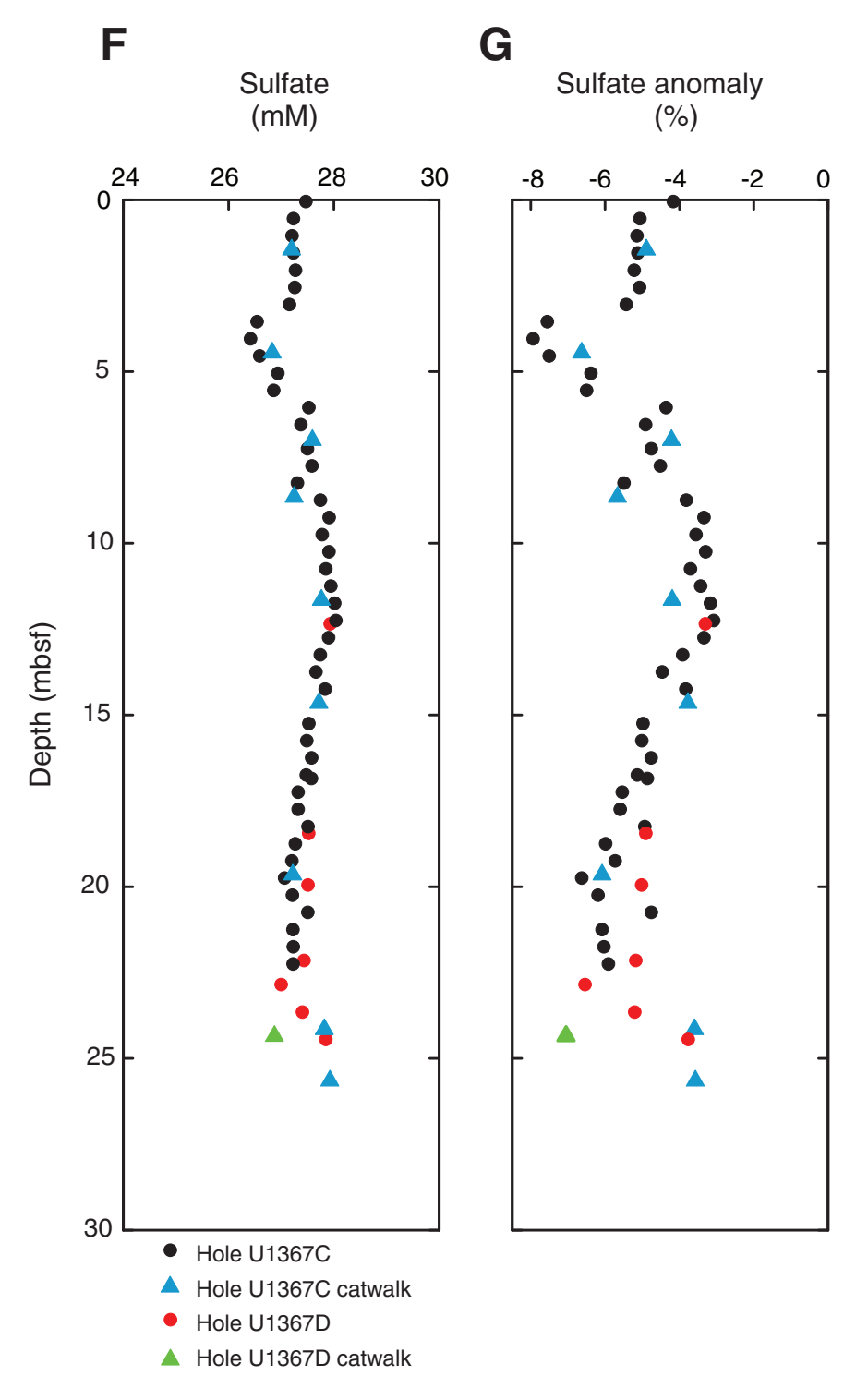

Chloride
$(\mathrm{mM})$
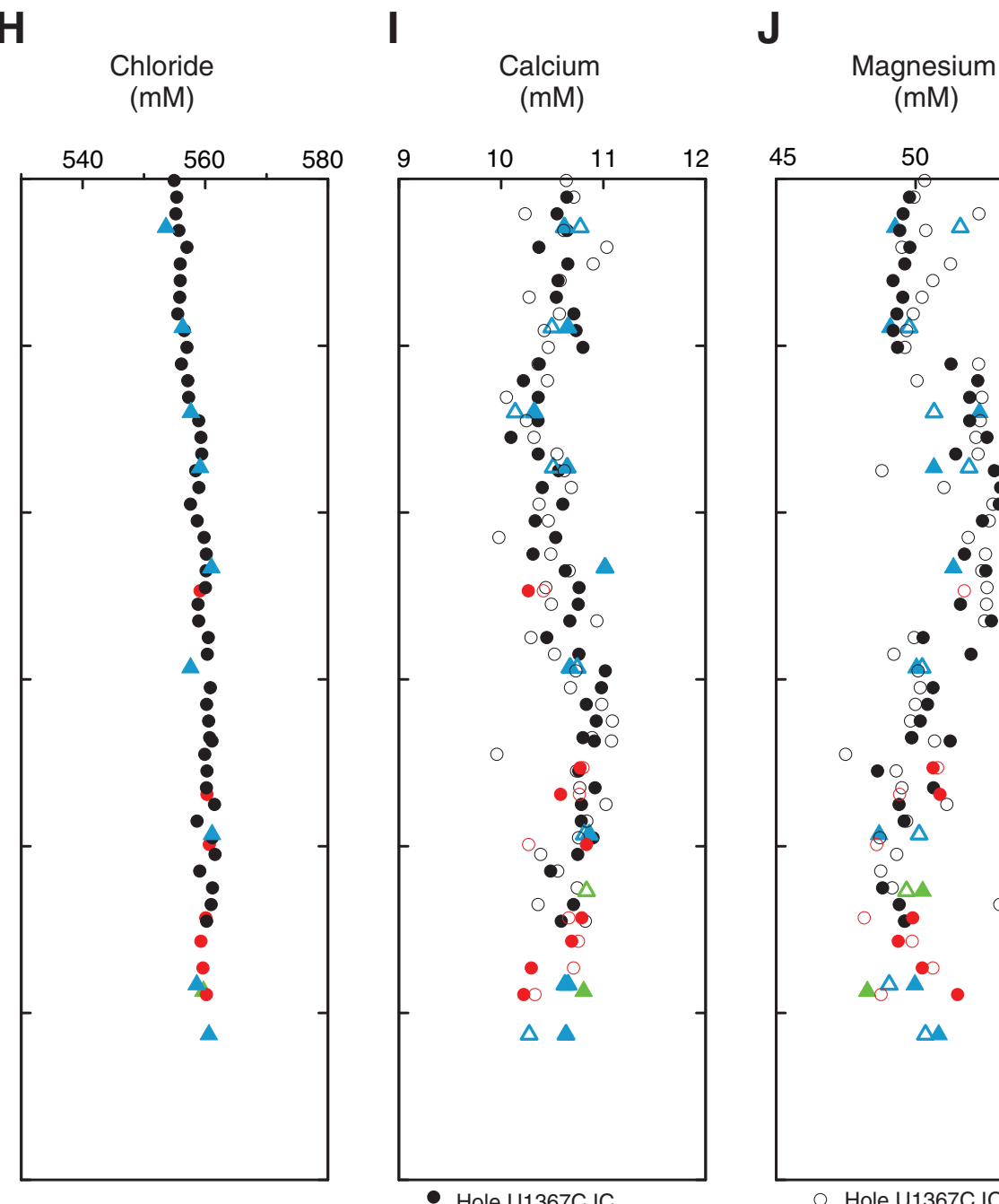

- Hole U1367C IC

Hole U1367C catwalk IC

- Hole U1367D IC

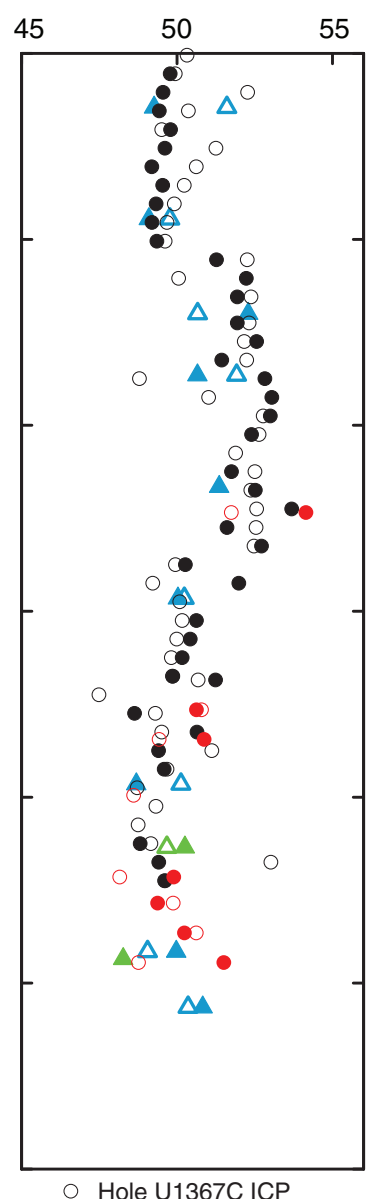

O Hole U1367C ICP

Hole U1367C catwalk ICP

○ Hole U1367D IPC

$\triangle$ Hole U1357D catwalk ICP 
Figure F37(continued). K. Potassium L. Sodium. M. Strontium.

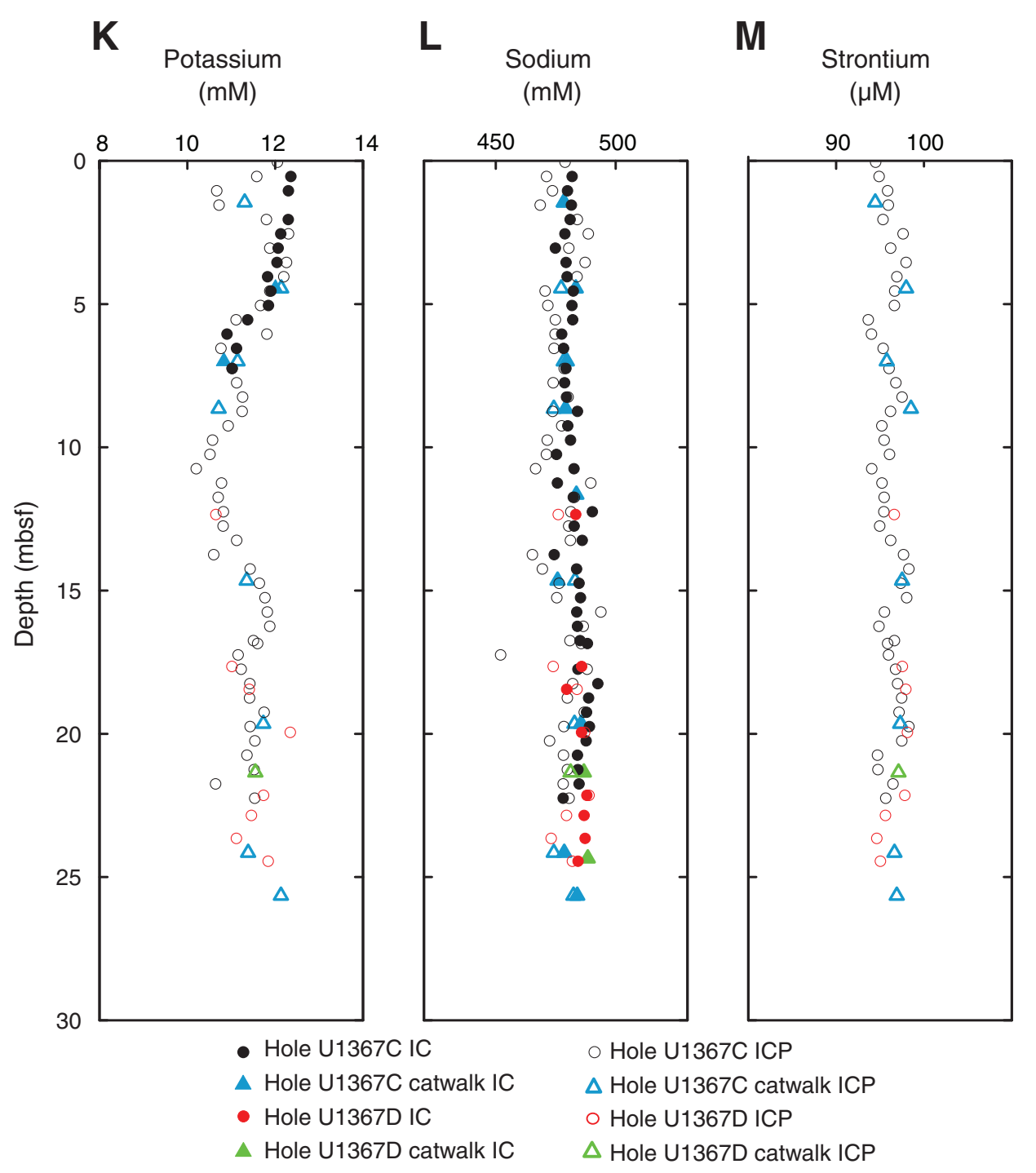


Figure F38. Plots of solid-phase nitrogen and carbon content, Hole U1367C. A. Total nitrogen (TN). B. Total organic carbon (TOC). C. Total carbonate $\left(\mathrm{CaCO}_{3}\right)$.

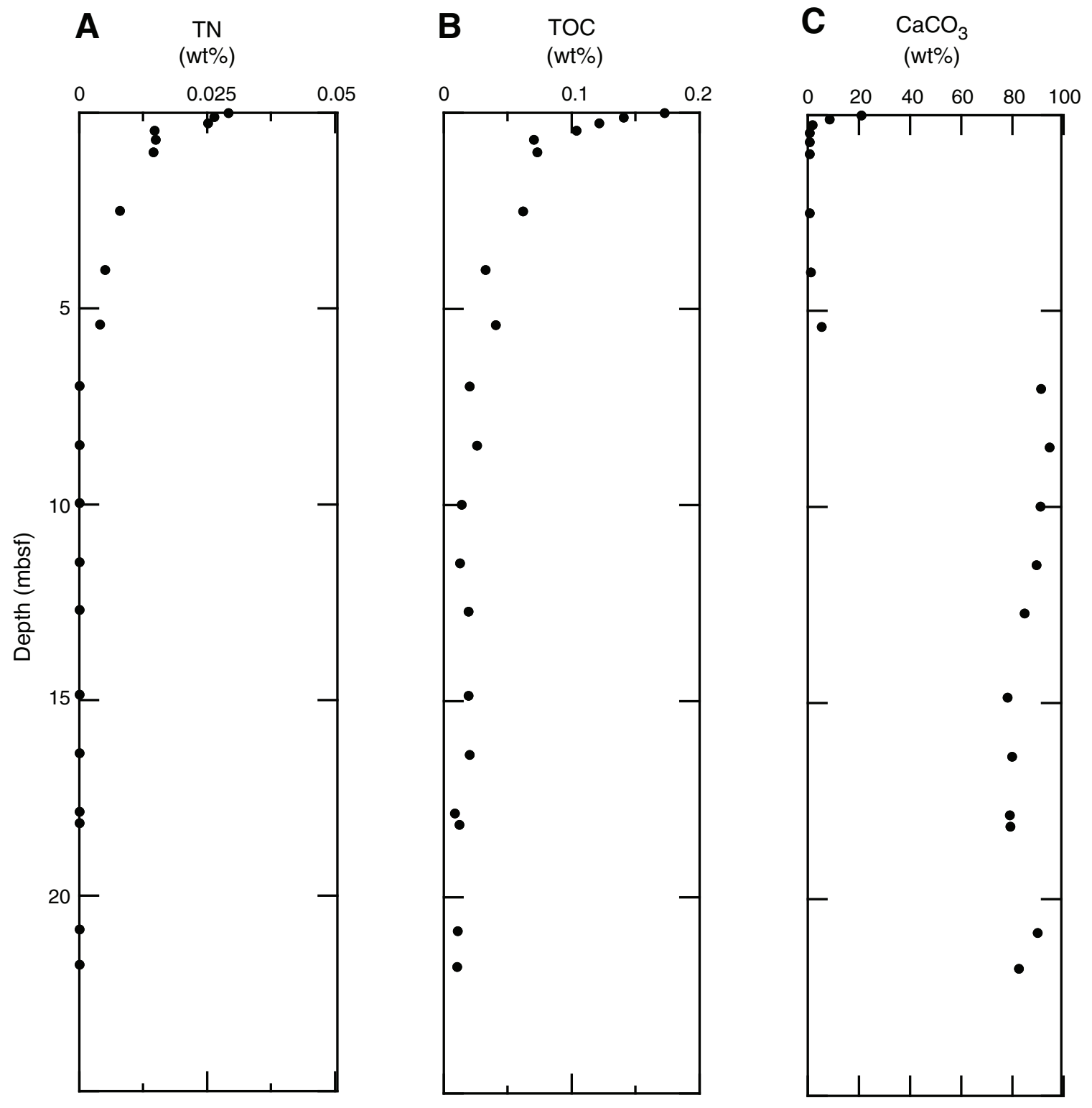


Figure F39. Plot of abundance of microbial cells and virus-like particles in Site U1367 sediment as determined by epifluorescence microscopy. Counts below the blank are shown as $10^{2} \mathrm{cells} / \mathrm{cm}^{3}$ in order to present them in the graph. See "Microbiology" in the "Methods" chapter (Expedition 329 Scientists, 2011a) for a detailed description of the blank and minimum detection limit (MDL) calculation. Red line = MDL for cell counts from extracts, blue line $=$ MDL for nonextracted samples, solid red circles $=$ abundances above MDL, open red circles = direct counts below MDL, solid black squares $=$ VLP counts, solid blue diamonds $=$ nonextracted direct counts above MDL, open blue diamonds = nonextracted direct counts below MDL.

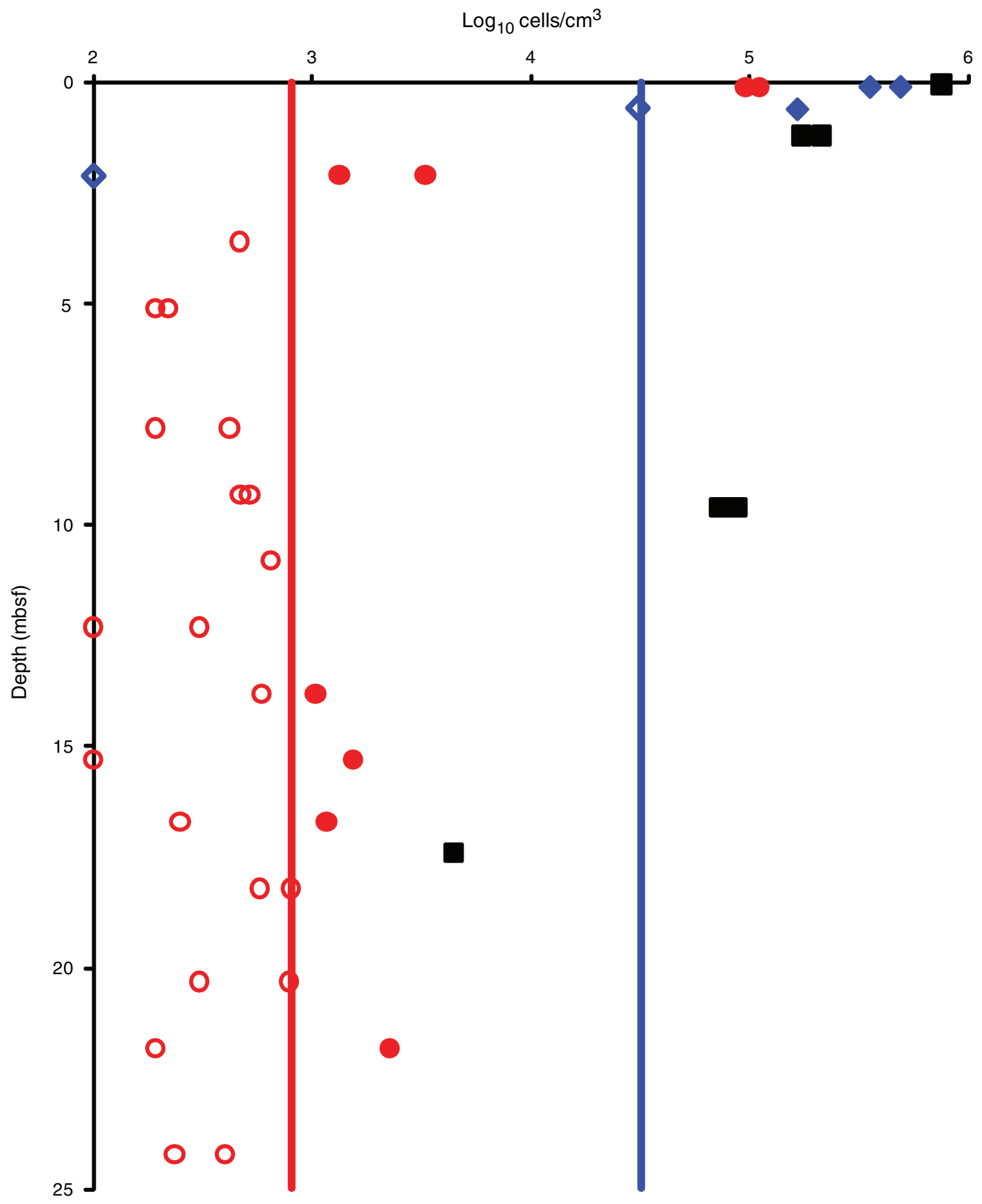


Figure F40. Concentrations of microsphere fluorescent beads detected from basaltic samples, Holes U1365E and U1367F. ND = not detected.

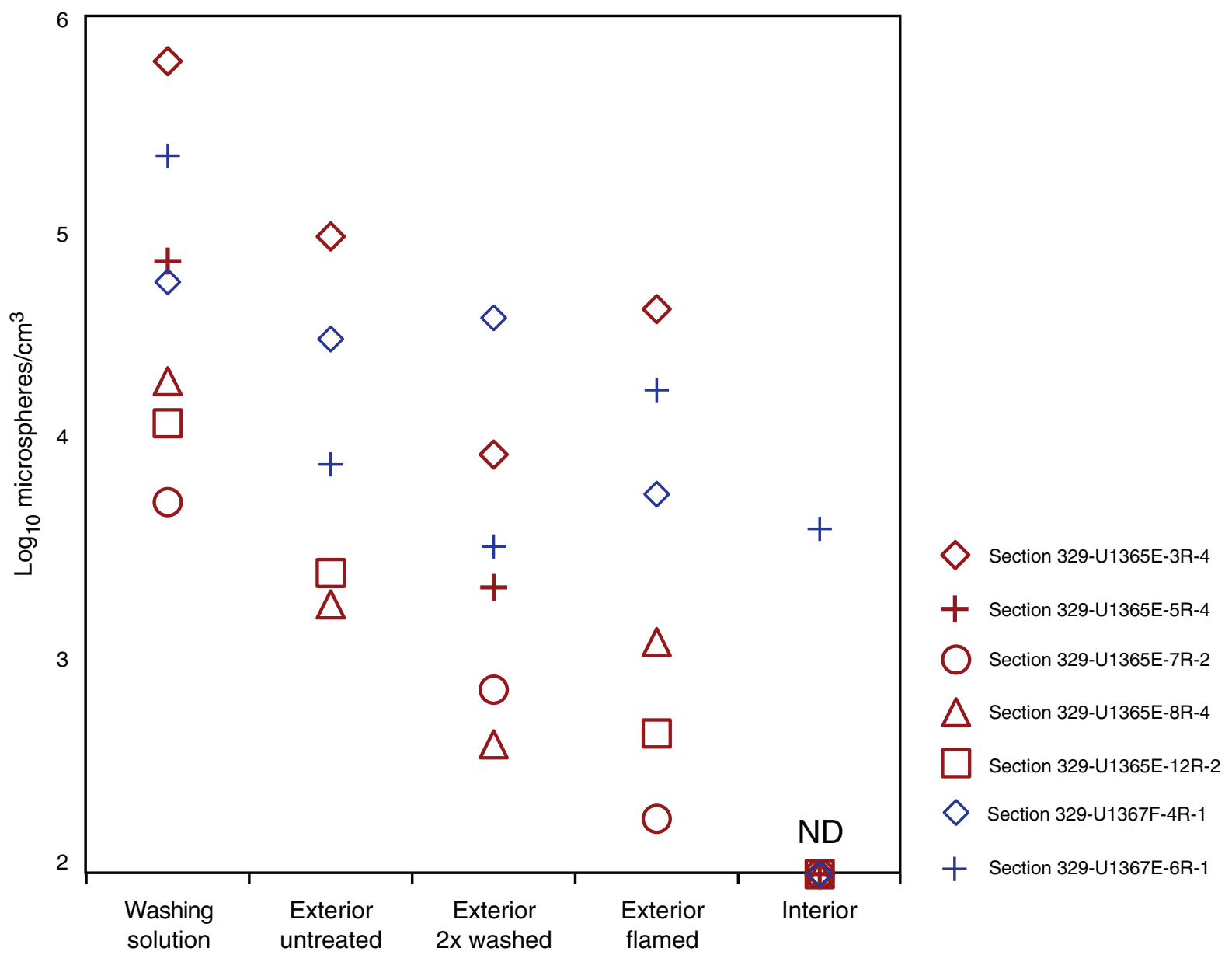


Table T1. Operations summary, Site U1367. (Continued on next page.)

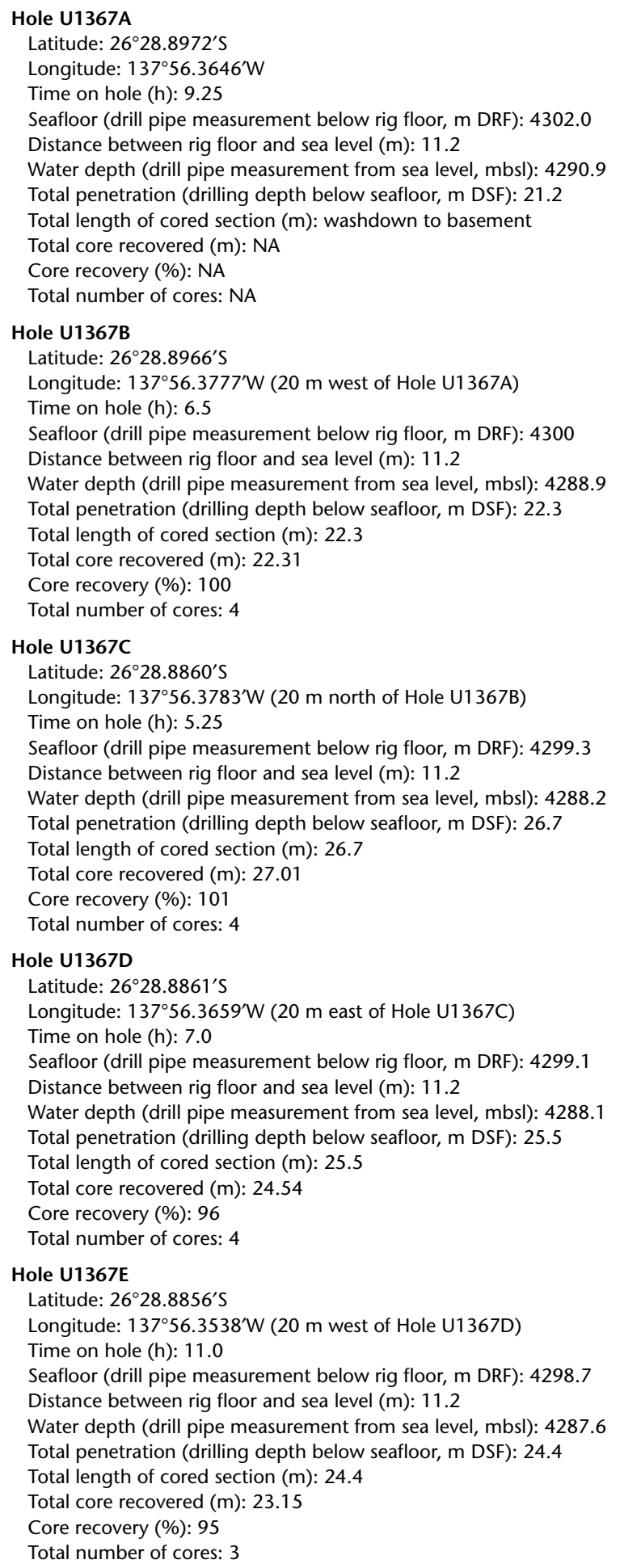


Table T1 (continued).

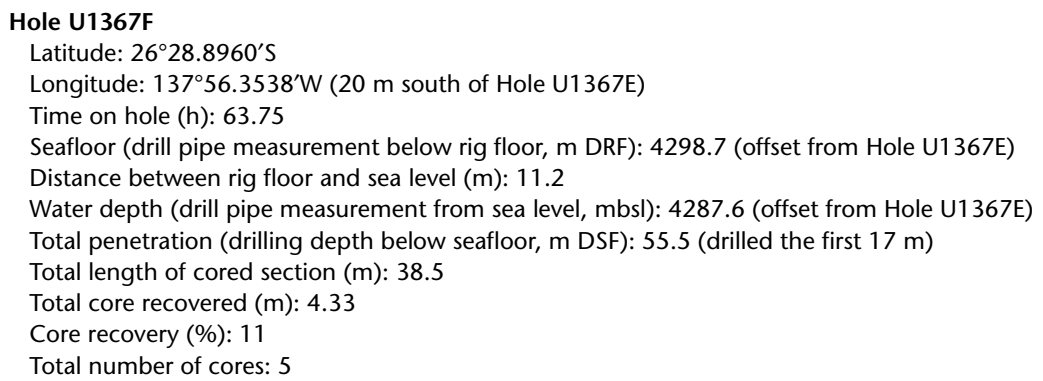

\begin{tabular}{|c|c|c|c|c|c|c|c|c|c|c|c|}
\hline \multirow[b]{2}{*}{ Core } & \multirow[b]{2}{*}{$\begin{array}{l}\text { Date } \\
(2010)\end{array}$} & \multirow[b]{2}{*}{$\begin{array}{l}\text { Time } \\
(\mathrm{h})\end{array}$} & \multicolumn{2}{|c|}{ Depth DSF (m) } & \multirow[b]{2}{*}{$\begin{array}{l}\text { Interval } \\
\text { advanced } \\
(\mathrm{m})\end{array}$} & \multicolumn{2}{|c|}{ Depth CSF (m) } & \multirow[b]{2}{*}{$\begin{array}{l}\text { Length of core } \\
\text { recovered } \\
\text { (m) }\end{array}$} & \multirow[b]{2}{*}{$\begin{array}{c}\text { Recovery } \\
\text { (\%) }\end{array}$} & \multirow[b]{2}{*}{$\begin{array}{l}\text { Sections } \\
(N)\end{array}$} & \multirow[b]{2}{*}{$\begin{array}{c}\text { Coring } \\
\text { shoe type }\end{array}$} \\
\hline & & & $\begin{array}{l}\text { Top of } \\
\text { cored } \\
\text { interval }\end{array}$ & $\begin{array}{l}\text { Bottom of } \\
\text { cored } \\
\text { interval }\end{array}$ & & $\begin{array}{l}\text { Top of } \\
\text { cored } \\
\text { interval }\end{array}$ & $\begin{array}{l}\text { Bottom of } \\
\text { cored } \\
\text { interval }\end{array}$ & & & & \\
\hline
\end{tabular}

329-U1367A-

115 Nov 1815 329-U1367B-

$1 \mathrm{H} \quad 5 \mathrm{Nov} \quad 2025$

$2 \mathrm{H} \quad 5 \mathrm{Nov} \quad 2150$

$3 \mathrm{H} \quad 5 \mathrm{Nov} \quad 2255$

$4 \mathrm{H} \quad 6 \mathrm{Nov} \quad 0015$

329-U1367C-

$1 \mathrm{H} \quad 6 \mathrm{Nov} \quad 0145$

$2 \mathrm{H} \quad 6 \mathrm{Nov} \quad 0250$

$3 \mathrm{H} \quad 6 \mathrm{Nov} \quad 0425$

$4 \mathrm{H} \quad 6 \mathrm{Nov} \quad 0540$

329-U1367D-

\begin{tabular}{|c|c|c|c|c|c|c|c|c|c|c|c|}
\hline \multicolumn{12}{|c|}{ 329-U1367D- } \\
\hline $1 \mathrm{H}$ & $6 \mathrm{Nov}$ & 0830 & 0.0 & 7.4 & 7.4 & 0.0 & 7.38 & 7.38 & 100 & 6 & STD \\
\hline $2 \mathrm{H}$ & $6 \mathrm{Nov}$ & 0955 & 7.4 & 16.9 & 9.5 & 7.4 & 15.97 & 8.57 & 90 & 7 & STD \\
\hline $3 \mathrm{H}$ & $6 \mathrm{Nov}$ & 1120 & 16.9 & 25.2 & 8.3 & 16.9 & 25.24 & 8.34 & 100 & 7 & STD \\
\hline $4 \mathrm{H}$ & $6 \mathrm{Nov}$ & 1245 & 25.2 & 25.5 & 0.3 & 25.2 & 25.45 & 0.25 & 83 & 1 & STD \\
\hline \multicolumn{12}{|c|}{ 329-U1367E- } \\
\hline $1 \mathrm{H}$ & $6 \mathrm{Nov}$ & 1410 & 0.0 & 6.8 & 6.8 & 0.0 & 6.80 & 6.80 & 100 & 6 & STD \\
\hline $2 \mathrm{H}$ & $6 \mathrm{Nov}$ & 1535 & 6.8 & 16.3 & 9.5 & 6.8 & 15.03 & 8.23 & 87 & 7 & STD \\
\hline $3 \mathrm{H}$ & $6 \mathrm{Nov}$ & 1700 & 16.3 & 24.4 & 8.1 & 16.3 & 24.42 & 8.12 & 100 & 7 & STD \\
\hline \multicolumn{12}{|c|}{ 329-U1367F- } \\
\hline $1 \mathrm{R}$ & $7 \mathrm{Nov}$ & 1020 & 0.0 & 17.0 & 17.0 & 0.0 & 0.00 & 0.00 & 0 & 0 & \\
\hline $2 \mathrm{R}$ & $7 \mathrm{Nov}$ & 1420 & 17.0 & 26.6 & 9.6 & 17.0 & 19.11 & 1.85 & 19 & 3 & \\
\hline $3 R$ & $7 \mathrm{Nov}$ & 2015 & 26.6 & 36.2 & 9.6 & 26.6 & 27.10 & 0.21 & 2 & 1 & \\
\hline $4 \mathrm{R}$ & $8 \mathrm{Nov}$ & 0515 & 36.2 & 45.9 & 9.7 & 36.2 & 37.18 & 0.65 & 7 & 1 & \\
\hline $5 \mathrm{R}$ & $8 \mathrm{Nov}$ & 1415 & 45.9 & 50.5 & 4.6 & 45.9 & 46.62 & 0.60 & 13 & 1 & \\
\hline \multirow[t]{3}{*}{$6 \mathrm{R}$} & $8 \mathrm{Nov}$ & 2235 & 50.5 & 55.5 & 5.0 & 50.5 & 51.52 & 1.02 & 20 & 1 & \\
\hline & & & \multicolumn{2}{|c|}{ Advanced total: } & 175.6 & & & 101.34 & 74 & 92 & \\
\hline & & & \multicolumn{2}{|c|}{ Total interval cored: } & 137.4 & & & & & & \\
\hline
\end{tabular}

$\mathrm{NA}=$ not applicable. $\mathrm{DSF}=$ drilling depth below seafloor, $\mathrm{CSF}=$ core depth below seafloor. $\mathrm{H}=\mathrm{APC}$ core, $\mathrm{R}=\mathrm{RCB}$ core, $1=$ drilled interval. STD = standard. Time is UTC. 
Table T2. ICP-AES analyses, Hole U1367F.

\begin{tabular}{|c|c|c|c|c|c|}
\hline \multirow[t]{2}{*}{ Hole: } & \multicolumn{5}{|c|}{ 329-U1367F- } \\
\hline & $2 \mathrm{R}$ & $4 \mathrm{R}$ & $4 R$ & $4 \mathrm{R}$ & $6 \mathrm{R}$ \\
\hline Section: & 3 & 1 & 1 & 1 & 1 \\
\hline Interval: & $60-63$ & $21-31$ & $51-53$ & $86-88$ & $38-40$ \\
\hline Depth (mbsf): & 18.95 & 22.10 & 36.71 & 37.06 & 50.88 \\
\hline Geological context: & Gray background & Altered chips & Chill margin & Pale gray interior & Gray background \\
\hline \multicolumn{6}{|c|}{ Major element oxide (wt\%): } \\
\hline $\mathrm{SiO}_{2}$ & 49.56 & 46.81 & 49.51 & 50.20 & 49.19 \\
\hline $\mathrm{Al}_{2} \mathrm{O}_{3}$ & 13.17 & 12.51 & 13.53 & 14.59 & 13.30 \\
\hline $\mathrm{Fe}_{2} \mathrm{O}_{3}(\mathrm{~T})$ & 14.74 & 17.60 & 15.49 & 11.75 & 13.80 \\
\hline $\mathrm{MnO}_{2}$ & 0.22 & 0.25 & 0.22 & 0.22 & 0.19 \\
\hline $\mathrm{MgO}$ & 5.84 & 6.16 & 5.99 & 6.34 & 6.11 \\
\hline $\mathrm{CaO}$ & 10.12 & 9.94 & 10.68 & 11.32 & 10.24 \\
\hline $\mathrm{Na}_{2} \mathrm{O}$ & 2.78 & 2.34 & 2.79 & 2.92 & 2.90 \\
\hline $\mathrm{K}_{2} \mathrm{O}$ & 0.37 & 0.92 & 0.38 & 0.24 & 0.13 \\
\hline $\mathrm{TiO}_{2}$ & 2.30 & 2.58 & 2.34 & 2.46 & 2.30 \\
\hline $\mathrm{P}_{2} \mathrm{O}_{5}$ & 0.25 & 0.23 & 0.25 & 0.37 & 0.26 \\
\hline Total: & 99.34 & 99.33 & 101.18 & 100.42 & 98.42 \\
\hline \multicolumn{6}{|l|}{ Trace element (ppm): } \\
\hline $\mathrm{Ba}$ & 18 & 36 & 7 & - & 21 \\
\hline Co & 62 & 63 & 67 & 78 & 65 \\
\hline $\mathrm{Cu}$ & 33 & 4 & 24 & 78 & 35 \\
\hline $\mathrm{Ni}$ & 29 & 34 & 37 & 39 & 40 \\
\hline Sc & 46 & 49 & 48 & 50 & 47 \\
\hline $\mathrm{Sr}$ & 120 & 115 & 120 & 167 & 116 \\
\hline V & 464 & 472 & 474 & 427 & 465 \\
\hline $\mathrm{Zn}$ & 106 & 141 & 110 & 197 & 117 \\
\hline $\mathrm{Zr}$ & 161 & 182 & 166 & 173 & 161 \\
\hline LOI (wt\%) & 0.43 & 1.59 & 0.48 & 0.92 & 0.46 \\
\hline
\end{tabular}

$\mathrm{LOI}=$ loss on ignition,$-=$ no data.

Table T3. Summary of veins and breccia, Site U1367.

\begin{tabular}{|c|c|c|c|c|c|c|c|c|c|c|c|}
\hline Core & $\begin{array}{l}\text { Recovery } \\
\text { (\%) }\end{array}$ & $\begin{array}{c}\text { Core top } \\
\text { depth (mbsf) }\end{array}$ & Total & Saponite & Celadonite & Carbonate & Pyrite & Smectite & Sediment & Quartz & Fe oxide \\
\hline \multicolumn{12}{|c|}{ 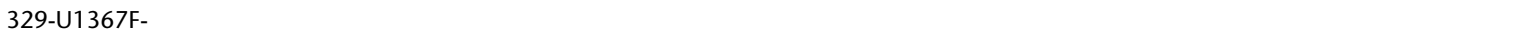 } \\
\hline $2 \mathrm{R}$ & 8.78 & 80.80 & 34.21 & 23.68 & 2.63 & 1.32 & 0.00 & 0.00 & 0.00 & 2.63 & 21.05 \\
\hline $3 R$ & 91.28 & 85.50 & 23.81 & 9.52 & 0.00 & 0.00 & 0.00 & 0.00 & 0.00 & 19.05 & 4.76 \\
\hline $4 \mathrm{R}$ & 66.60 & 90.50 & 16.67 & 15.00 & 5.00 & 0.00 & 0.00 & 0.00 & 0.00 & 5.00 & 6.67 \\
\hline $5 \mathrm{R}$ & 99.15 & 90.50 & 3.33 & 0.00 & 0.00 & 0.00 & 0.00 & 0.00 & 0.00 & 3.33 & 0.00 \\
\hline \multirow[t]{2}{*}{$6 \mathrm{R}$} & 87.00 & 95.20 & 20.59 & 2.94 & 13.73 & 0.98 & 5.88 & 0.00 & 0.00 & 0.00 & 3.92 \\
\hline & & Average: & 19.722 & 10.230 & 4.271 & 0.459 & 1.176 & 0.000 & 0.000 & 6.003 & 7.281 \\
\hline \multicolumn{12}{|c|}{ Volume (\%) veins } \\
\hline $2 \mathrm{R}$ & 8.78 & 80.80 & 0.39 & 0.16 & 0.01 & 0.03 & 0.00 & 0.00 & 0.00 & 0.02 & 0.15 \\
\hline $3 R$ & 91.28 & 85.50 & 0.29 & 0.04 & 0.00 & 0.00 & 0.00 & 0.00 & 0.10 & 0.05 & 0.10 \\
\hline $4 \mathrm{R}$ & 66.60 & 90.50 & 0.18 & 0.12 & 0.01 & 0.00 & 0.00 & 0.00 & 0.00 & 0.04 & 0.02 \\
\hline $5 \mathrm{R}$ & 99.15 & 90.50 & 0.05 & 0.00 & 0.00 & 0.00 & 0.00 & 0.00 & 0.00 & 0.05 & 0.00 \\
\hline \multirow[t]{2}{*}{$6 \mathrm{R}$} & 87.00 & 95.20 & 0.24 & 0.01 & 0.14 & 0.00 & 0.05 & 0.00 & 0.00 & 0.00 & 0.03 \\
\hline & & Average: & 0.230 & 0.065 & 0.031 & 0.006 & 0.011 & 0.000 & 0.021 & 0.032 & 0.059 \\
\hline \multicolumn{12}{|c|}{ Area of vein recovered $\left(\mathrm{cm}^{3}\right)$} \\
\hline $2 \mathrm{R}$ & 8.78 & 80.80 & 1.80 & 0.72 & 0.04 & 0.12 & 0 & 0 & 0 & 0.102 & 0.69 \\
\hline $3 \mathrm{R}$ & 91.28 & 85.50 & 0.36 & 0.05 & 0 & 0 & 0 & 0 & 0.13 & 0.06 & 0.12 \\
\hline $4 \mathrm{R}$ & 66.60 & 90.50 & 0.66 & 0.41 & 0.03 & 0 & 0 & 0 & 0 & 0.14 & 0.07 \\
\hline $5 \mathrm{R}$ & 99.15 & 90.50 & 0.18 & 0 & 0 & 0 & 0 & 0 & 0 & 0.18 & 0 \\
\hline \multirow[t]{4}{*}{$6 \mathrm{R}$} & 87.00 & 95.20 & 1.69 & 0.11 & 0.97 & 0.01 & 0.39 & 0 & 0 & 0 & 0.22 \\
\hline & & Total: & 4.69 & 1.29 & 1.05 & 0.13 & 0.39 & 0.00 & 0.13 & 0.49 & 1.10 \\
\hline & Tota & volume (\%): & 100.00 & 27.50 & 22.30 & 2.80 & 8.30 & 0.00 & 2.80 & 10.40 & 23.40 \\
\hline & Total volum & (\%) of core: & 0.23 & 0.06 & 0.05 & 0.01 & 0.02 & 0 & 0.01 & 0.02 & 0.05 \\
\hline
\end{tabular}


Table T4. Distribution and overall and relative abundance of planktonic foraminifers, Site U1367.

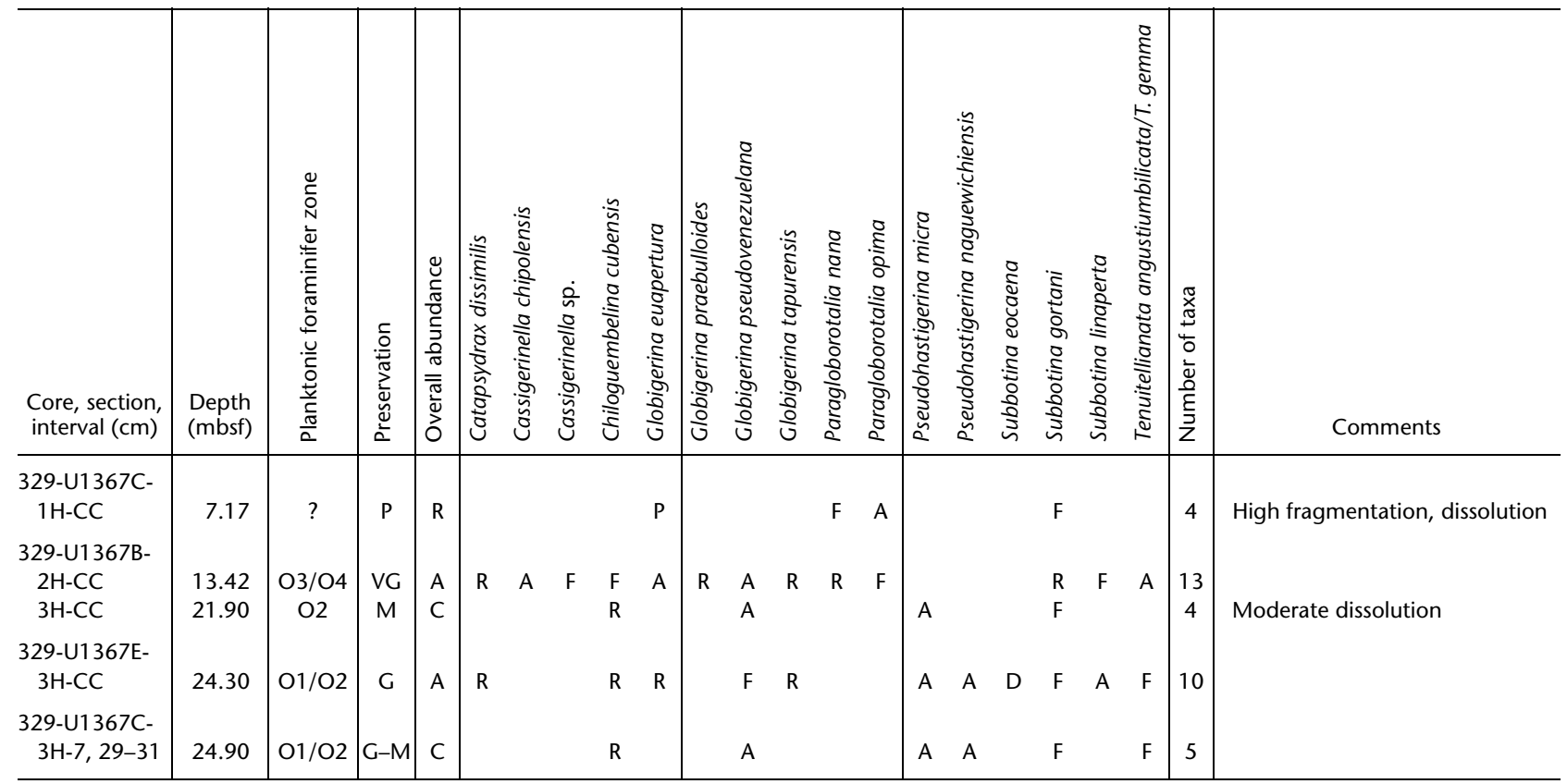

Preservation: $V G=$ very good,$G=$ good,$M=$ moderate, $P=$ poor. Abundance: $D=$ dominant,$A=$ abundant,$C=$ common, $F=$ few, $R=$ rare, $\mathrm{P}=$ present. Foraminifer zonations based on Wade et al. (2011), ? = uncertainty. For more specific preservation and abundance definitions, refer to "Paleontology and biostratigraphy" in the "Methods" chapter (Expedition 329 Scientists, 2011a).

Table T5. Distribution and overall and relative abundance of benthic foraminifers, Site U1367.

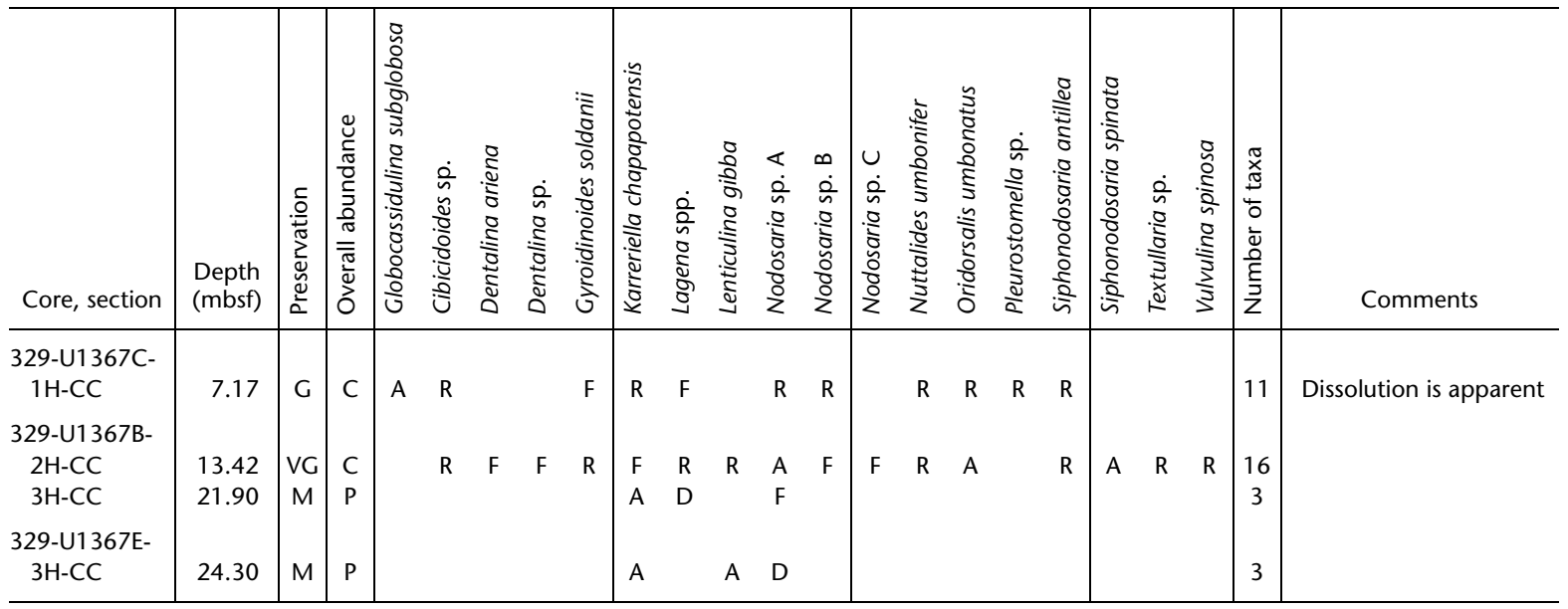

Preservation: $V G=$ very good, $G=$ good, $M=$ moderate. Abundance: $D=$ dominant, $A=$ abundant $C=$ common, $F=$ few, $R=$ rare, $P=$ present. For more specific preservation and abundance definitions, refer to "Paleontology and biostratigraphy" in the "Methods" chapter (Expedition 329 Scientists, 2011a). 
Table T6. Distribution and overall and relative abundance of ostracods, Site U1367.

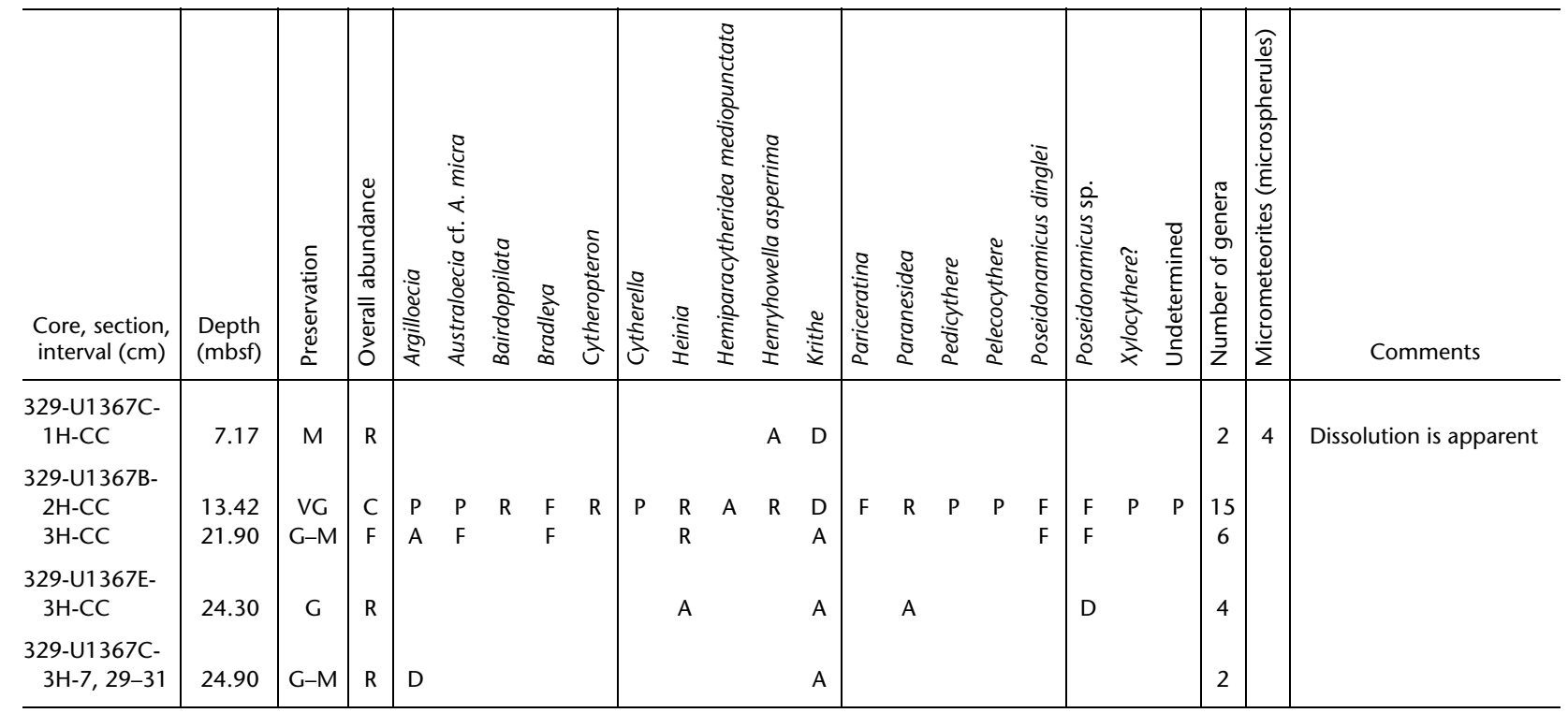

Preservation: $V G=$ very good, $G=$ good, $M=$ moderate. Abundance: $D=$ dominant, $A=$ abundant, $C=$ common, $F=$ few, $R=$ rare, $P=$ present. For more specific preservation and abundance definitions, refer to "Paleontology and biostratigraphy" in the "Methods" chapter (Expedition 329 Scientists, 2011a).

Table T7. Electrical conductivity measurements of surface seawater, Site U1367.

\begin{tabular}{|c|c|c|c|c|}
\hline $\begin{array}{l}\text { Measurement } \\
\text { number }\end{array}$ & $\begin{array}{l}\text { Electrical } \\
\text { conductivity } \\
(\mathrm{mS} / \mathrm{cm})\end{array}$ & $\begin{array}{c}\text { Temperature } \\
\left({ }^{\circ} \mathrm{C}\right)\end{array}$ & $\begin{array}{l}\text { Correction } \\
\text { factor at } 20^{\circ} \mathrm{C} \\
(\mathrm{mS} / \mathrm{cm})\end{array}$ & $\begin{array}{c}\text { Seawater electrical } \\
\text { conductivity at } 20^{\circ} \mathrm{C} \\
(\mathrm{mS} / \mathrm{cm})\end{array}$ \\
\hline 9 & 52.51 & 22.5 & 50.46 & 49.84 \\
\hline 16 & 52.55 & 22.1 & 50.04 & 50.29 \\
\hline 25 & 51.95 & 21.9 & 49.84 & 49.92 \\
\hline 32 & 52.08 & 21.9 & 49.84 & 50.05 \\
\hline 41 & 51.95 & 21.9 & 49.84 & 49.92 \\
\hline 48 & 51.59 & 21.8 & 49.74 & 49.68 \\
\hline 57 & 51.44 & 21.6 & 49.53 & 49.74 \\
\hline 64 & 51.41 & 21.6 & 49.53 & 49.71 \\
\hline 72 & 51.30 & 21.7 & 49.63 & 49.50 \\
\hline 80 & 50.98 & 21.7 & 49.63 & 49.19 \\
\hline 88 & 51.25 & 21.8 & 49.74 & 49.35 \\
\hline 89 & 51.79 & 22.1 & 50.04 & 49.56 \\
\hline 98 & 51.85 & 22.1 & 50.04 & 49.62 \\
\hline 114 & 51.86 & 22.0 & 49.94 & 49.73 \\
\hline 122 & 51.78 & 21.9 & 49.84 & 49.76 \\
\hline 131 & 51.75 & 22.0 & 49.94 & 49.63 \\
\hline 139 & 51.83 & 21.8 & 49.74 & 49.91 \\
\hline 149 & 51.74 & 21.9 & 49.84 & 49.72 \\
\hline 150 & 51.77 & 22.0 & 49.94 & 49.65 \\
\hline 159 & 51.74 & 21.8 & 49.74 & 49.82 \\
\hline 167 & 51.74 & 21.9 & 49.84 & 49.72 \\
\hline 175 & 51.71 & 21.9 & 49.84 & 49.69 \\
\hline 183 & 51.68 & 21.9 & 49.84 & 49.66 \\
\hline 192 & 51.64 & 21.9 & 49.84 & 49.62 \\
\hline 200 & 51.60 & 21.8 & 49.74 & 49.69 \\
\hline 208 & 51.58 & 21.8 & 49.74 & 49.67 \\
\hline 216 & 51.51 & 21.8 & 49.74 & 49.60 \\
\hline 224 & 51.53 & 21.7 & 49.63 & 49.72 \\
\hline 230 & 51.57 & 21.7 & 49.63 & 49.76 \\
\hline 236 & 51.42 & 21.7 & 49.63 & 49.62 \\
\hline
\end{tabular}


Table T8. Formation factor measurements, Site U1367. (Continued on next three pages.)

\begin{tabular}{|c|c|c|c|c|c|c|c|c|c|}
\hline $\begin{array}{l}\text { Core, section, } \\
\text { interval }(\mathrm{cm})\end{array}$ & $\begin{array}{l}\text { Depth } \\
\text { (mbsf) }\end{array}$ & $\begin{array}{l}\text { Measurement } \\
\text { number }\end{array}$ & $\begin{array}{l}\text { Temperature- } \\
\text { corrected } \\
\text { seawater } \\
\text { conductivity } \\
(\mathrm{mS} / \mathrm{cm})\end{array}$ & $\begin{array}{l}\text { Sediment } \\
\text { temperature } \\
\left({ }^{\circ} \mathrm{C}\right)\end{array}$ & $\begin{array}{c}\text { Sediment } \\
\text { electrical } \\
\text { conductivity } \\
(\mathrm{mS} / \mathrm{cm})\end{array}$ & $\begin{array}{c}\text { Correction } \\
\text { factor at } 20^{\circ} \mathrm{C} \\
(\mathrm{mS} / \mathrm{cm})\end{array}$ & $\begin{array}{c}\text { Sediment } \\
\text { electrical } \\
\text { conductivity at } \\
20^{\circ} \mathrm{C}(\mathrm{mS} / \mathrm{cm})\end{array}$ & $\begin{array}{l}\text { Drift-corrected } \\
\text { sediment } \\
\text { electrical } \\
\text { conductivity at } \\
20^{\circ} \mathrm{C}(\mathrm{mS} / \mathrm{cm})\end{array}$ & $\begin{array}{l}\text { Formation } \\
\text { factor }\end{array}$ \\
\hline \multicolumn{10}{|l|}{ 329-U1367B- } \\
\hline $1 \mathrm{H}-1,2$ & 0.02 & 90 & 49.81 & 21.00 & 27.98 & 48.91 & 27.40 & 27.44 & 1.81 \\
\hline $1 \mathrm{H}-1,10$ & 0.10 & 91 & 49.81 & 21.00 & 26.87 & 48.91 & 26.31 & 26.35 & 1.89 \\
\hline $1 \mathrm{H}-1,20$ & 0.20 & 92 & 49.81 & 21.00 & 28.21 & 48.91 & 27.62 & 27.66 & 1.80 \\
\hline $1 \mathrm{H}-1,30$ & 0.30 & 93 & 49.81 & 21.00 & 26.74 & 48.91 & 26.18 & 26.22 & 1.90 \\
\hline $1 \mathrm{H}-1,40$ & 0.40 & 94 & 49.81 & 21.00 & 26.31 & 48.91 & 25.76 & 25.80 & 1.93 \\
\hline $1 \mathrm{H}-1,50$ & 0.50 & 95 & 49.81 & 21.00 & 26.00 & 48.91 & 25.46 & 25.50 & 1.95 \\
\hline $1 \mathrm{H}-1,60$ & 0.60 & 96 & 49.81 & 21.00 & 25.15 & 48.91 & 24.62 & 24.66 & 2.02 \\
\hline $1 \mathrm{H}-1,73$ & 0.73 & 97 & 49.81 & 21.80 & 24.68 & 49.74 & 23.77 & 23.80 & 2.09 \\
\hline $1 \mathrm{H}-1,80$ & 0.80 & 99 & 49.81 & 21.10 & 24.14 & 49.02 & 23.59 & 23.62 & 2.11 \\
\hline $1 \mathrm{H}-1,90$ & 0.90 & 100 & 49.80 & 21.10 & 25.06 & 49.02 & 24.49 & 24.53 & 2.03 \\
\hline $1 \mathrm{H}-1,100$ & 1.00 & 101 & 49.80 & 21.10 & 24.90 & 49.02 & 24.33 & 24.37 & 2.04 \\
\hline $1 \mathrm{H}-1,110$ & 1.10 & 102 & 49.80 & 21.10 & 23.67 & 49.02 & 23.13 & 23.17 & 2.15 \\
\hline $1 \mathrm{H}-1,120$ & 1.20 & 103 & 49.80 & 21.10 & 25.20 & 49.02 & 24.62 & 24.66 & 2.02 \\
\hline $1 \mathrm{H}-1,130$ & 1.30 & 104 & 49.80 & 21.10 & 24.63 & 49.02 & 24.07 & 24.11 & 2.06 \\
\hline $1 \mathrm{H}-1,140$ & 1.40 & 105 & 49.80 & 21.10 & 24.78 & 49.02 & 24.21 & 24.25 & 2.05 \\
\hline $1 \mathrm{H}-2,10$ & 1.60 & 107 & 49.80 & 20.90 & 25.25 & 48.81 & 24.77 & 24.82 & 2.00 \\
\hline $1 \mathrm{H}-2,20$ & 1.70 & 108 & 49.80 & 20.90 & 23.68 & 48.81 & 23.23 & 23.28 & 2.14 \\
\hline $1 \mathrm{H}-2,30$ & 1.80 & 109 & 49.80 & 20.90 & 24.70 & 48.81 & 24.23 & 24.28 & 2.05 \\
\hline $1 \mathrm{H}-2,40$ & 1.90 & 110 & 49.80 & 20.90 & 23.91 & 48.81 & 23.46 & 23.50 & 2.12 \\
\hline $1 \mathrm{H}-2,50$ & 2.00 & 111 & 49.80 & 20.90 & 24.49 & 48.81 & 24.03 & 24.07 & 2.07 \\
\hline $1 \mathrm{H}-2,60$ & 2.10 & 112 & 49.79 & 20.90 & 24.65 & 48.81 & 24.19 & 24.23 & 2.05 \\
\hline $1 \mathrm{H}-2,74$ & 2.24 & 113 & 49.79 & 20.90 & 24.03 & 48.81 & 23.58 & 23.62 & 2.10 \\
\hline $1 \mathrm{H}-2,80$ & 2.30 & 115 & 49.79 & 20.90 & 24.79 & 48.81 & 24.32 & 24.37 & 2.04 \\
\hline $1 \mathrm{H}-2,90$ & 2.40 & 116 & 49.79 & 20.90 & 24.40 & 48.81 & 23.94 & 23.99 & 2.07 \\
\hline $1 \mathrm{H}-2,100$ & 2.50 & 117 & 49.79 & 20.90 & 23.61 & 48.81 & 23.17 & 23.21 & 2.14 \\
\hline $1 \mathrm{H}-2,110$ & 2.60 & 118 & 49.79 & 20.90 & 23.15 & 48.81 & 22.71 & 22.76 & 2.18 \\
\hline $1 \mathrm{H}-2,120$ & 2.70 & 119 & 49.79 & 20.90 & 24.43 & 48.81 & 23.97 & 24.02 & 2.07 \\
\hline $1 \mathrm{H}-2,130$ & 2.80 & 120 & 49.79 & 20.80 & 24.40 & 48.71 & 23.99 & 24.04 & 2.07 \\
\hline $1 \mathrm{H}-2,140$ & 2.90 & 121 & 49.79 & 20.80 & 24.71 & 48.71 & 24.30 & 24.34 & 2.04 \\
\hline $1 \mathrm{H}-3,2$ & 3.04 & 123 & 49.79 & 20.90 & 25.72 & 48.81 & 25.24 & 25.29 & 1.97 \\
\hline $1 \mathrm{H}-3,10$ & 3.12 & 124 & 49.78 & 20.90 & 25.54 & 48.81 & 25.06 & 25.11 & 1.98 \\
\hline $1 \mathrm{H}-3,20$ & 3.22 & 125 & 49.78 & 20.90 & 25.20 & 48.81 & 24.73 & 24.78 & 2.01 \\
\hline $1 \mathrm{H}-3,30$ & 3.32 & 126 & 49.78 & 20.90 & 24.97 & 48.81 & 24.50 & 24.55 & 2.02 \\
\hline $1 \mathrm{H}-3,40$ & 3.42 & 127 & 49.78 & 20.90 & 24.38 & 48.81 & 23.92 & 23.97 & 2.07 \\
\hline $1 \mathrm{H}-3,50$ & 3.52 & 128 & 49.78 & 20.90 & 25.21 & 48.81 & 24.74 & 24.79 & 2.01 \\
\hline $1 \mathrm{H}-3,60$ & 3.62 & 129 & 49.78 & 20.90 & 25.78 & 48.81 & 25.29 & 25.35 & 1.96 \\
\hline $1 \mathrm{H}-3,74$ & 3.76 & 130 & 49.78 & 20.90 & 25.74 & 48.81 & 25.26 & 25.31 & 1.96 \\
\hline $1 \mathrm{H}-3,80$ & 3.82 & 132 & 49.78 & 20.80 & 26.70 & 48.71 & 26.25 & 26.31 & 1.89 \\
\hline $1 \mathrm{H}-3,90$ & 3.92 & 133 & 49.78 & 20.80 & 25.98 & 48.71 & 25.54 & 25.60 & 1.94 \\
\hline $1 \mathrm{H}-3,100$ & 4.02 & 134 & 49.78 & 20.70 & 27.16 & 48.61 & 26.76 & 26.82 & 1.85 \\
\hline $1 \mathrm{H}-3,110$ & 4.12 & 135 & 49.78 & 20.70 & 26.47 & 48.61 & 26.08 & 26.14 & 1.90 \\
\hline $1 \mathrm{H}-3,120$ & 4.22 & 136 & 49.78 & 20.70 & 26.37 & 48.61 & 25.98 & 26.04 & 1.91 \\
\hline $1 \mathrm{H}-3,130$ & 4.32 & 137 & 49.77 & 20.70 & 26.85 & 48.61 & 26.46 & 26.51 & 1.87 \\
\hline $1 \mathrm{H}-3,140$ & 4.42 & 138 & 49.77 & 20.70 & 27.40 & 48.61 & 27.00 & 27.06 & 1.84 \\
\hline $1 \mathrm{H}-4,2$ & 4.54 & 140 & 49.77 & 20.80 & 27.45 & 48.71 & 26.99 & 27.05 & 1.84 \\
\hline $1 \mathrm{H}-4,20$ & 4.72 & 141 & 49.77 & 20.80 & 26.91 & 48.71 & 26.46 & 26.52 & 1.87 \\
\hline $1 \mathrm{H}-4,30$ & 4.82 & 142 & 49.77 & 20.80 & 26.89 & 48.71 & 26.44 & 26.50 & 1.88 \\
\hline $1 \mathrm{H}-4,40$ & 4.92 & 143 & 49.77 & 20.80 & 26.63 & 48.71 & 26.18 & 26.24 & 1.89 \\
\hline $1 \mathrm{H}-4,50$ & 5.02 & 144 & 49.77 & 20.80 & 26.01 & 48.71 & 25.57 & 25.63 & 1.94 \\
\hline $1 \mathrm{H}-4,60$ & 5.12 & 145 & 49.77 & 20.80 & 27.19 & 48.71 & 26.73 & 26.80 & 1.85 \\
\hline $1 \mathrm{H}-4,70$ & 5.22 & 146 & 49.77 & 20.80 & 26.03 & 48.71 & 25.59 & 25.65 & 1.94 \\
\hline $1 \mathrm{H}-4,80$ & 5.32 & 147 & 49.77 & 20.80 & 27.14 & 48.71 & 26.68 & 26.75 & 1.86 \\
\hline $1 \mathrm{H}-4,98$ & 5.50 & 148 & 49.76 & 20.80 & 27.57 & 48.71 & 27.11 & 27.17 & 1.83 \\
\hline $2 \mathrm{H}-1,5$ & 5.55 & 151 & 49.76 & 21.00 & 27.20 & 48.91 & 26.63 & 26.70 & 1.86 \\
\hline $2 \mathrm{H}-1,10$ & 5.60 & 152 & 49.76 & 21.00 & 28.81 & 48.91 & 28.21 & 28.28 & 1.76 \\
\hline $2 \mathrm{H}-1,20$ & 5.70 & 153 & 49.76 & 20.80 & 20.32 & 48.71 & 19.98 & 20.03 & 2.48 \\
\hline $2 \mathrm{H}-1,30$ & 5.80 & 154 & 49.76 & 20.80 & 20.89 & 48.71 & 20.54 & 20.59 & 2.41 \\
\hline $2 \mathrm{H}-1,40$ & 5.90 & 155 & 49.76 & 20.80 & 21.30 & 48.71 & 20.94 & 21.00 & 2.37 \\
\hline $2 \mathrm{H}-1,50$ & 6.00 & 156 & 49.76 & 20.80 & 20.85 & 48.71 & 20.50 & 20.55 & 2.42 \\
\hline $2 \mathrm{H}-1,60$ & 6.10 & 157 & 49.76 & 20.80 & 20.22 & 48.71 & 19.88 & 19.93 & 2.49 \\
\hline $2 \mathrm{H}-1,70$ & 6.20 & 158 & 49.76 & 20.80 & 21.11 & 48.71 & 20.76 & 20.81 & 2.39 \\
\hline $2 \mathrm{H}-1,80$ & 6.30 & 160 & 49.76 & 20.80 & 20.21 & 48.71 & 19.87 & 19.92 & 2.49 \\
\hline $2 \mathrm{H}-1,90$ & 6.40 & 161 & 49.76 & 20.80 & 20.93 & 48.71 & 20.58 & 20.63 & 2.41 \\
\hline $2 \mathrm{H}-1,100$ & 6.50 & 162 & 49.75 & 20.80 & 21.11 & 48.71 & 20.76 & 20.81 & 2.39 \\
\hline $2 \mathrm{H}-1,110$ & 6.60 & 163 & 49.75 & 20.80 & 21.23 & 48.71 & 20.87 & 20.93 & 2.37 \\
\hline
\end{tabular}


Table T8 (continued). (Continued on next page.)

\begin{tabular}{|c|c|c|c|c|c|c|c|c|c|}
\hline $\begin{array}{l}\text { Core, section, } \\
\text { interval }(\mathrm{cm})\end{array}$ & $\begin{array}{l}\text { Depth } \\
\text { (mbsf) }\end{array}$ & $\begin{array}{c}\text { Measurement } \\
\text { number }\end{array}$ & $\begin{array}{l}\text { Temperature- } \\
\text { corrected } \\
\text { seawater } \\
\text { conductivity } \\
(\mathrm{mS} / \mathrm{cm})\end{array}$ & $\begin{array}{l}\text { Sediment } \\
\text { temperature } \\
\left({ }^{\circ} \mathrm{C}\right)\end{array}$ & $\begin{array}{c}\text { Sediment } \\
\text { electrical } \\
\text { conductivity } \\
(\mathrm{mS} / \mathrm{cm})\end{array}$ & $\begin{array}{l}\text { Correction } \\
\text { factor at } 20^{\circ} \mathrm{C} \\
(\mathrm{mS} / \mathrm{cm})\end{array}$ & $\begin{array}{c}\text { Sediment } \\
\text { electrical } \\
\text { conductivity at } \\
20^{\circ} \mathrm{C}(\mathrm{mS} / \mathrm{cm})\end{array}$ & $\begin{array}{l}\text { Drift-corrected } \\
\text { sediment } \\
\text { electrical } \\
\text { conductivity at } \\
20^{\circ} \mathrm{C}(\mathrm{mS} / \mathrm{cm})\end{array}$ & $\begin{array}{l}\text { Formation } \\
\text { factor }\end{array}$ \\
\hline $2 \mathrm{H}-1,120$ & 6.70 & 164 & 49.75 & 20.80 & 20.73 & 48.71 & 20.38 & 20.44 & 2.43 \\
\hline $2 \mathrm{H}-1,130$ & 6.80 & 165 & 49.75 & 20.80 & 20.50 & 48.71 & 20.16 & 20.21 & 2.46 \\
\hline $2 \mathrm{H}-1,140$ & 6.90 & 166 & 49.75 & 20.80 & 20.23 & 48.71 & 19.89 & 19.94 & 2.49 \\
\hline $2 \mathrm{H}-2,10$ & 7.10 & 168 & 49.75 & 20.90 & 20.11 & 48.81 & 19.73 & 19.79 & 2.51 \\
\hline $2 \mathrm{H}-2,20$ & 7.20 & 169 & 49.75 & 20.90 & 19.58 & 48.81 & 19.21 & 19.26 & 2.58 \\
\hline $2 \mathrm{H}-2,30$ & 7.30 & 170 & 49.75 & 20.90 & 19.90 & 48.81 & 19.53 & 19.58 & 2.54 \\
\hline $2 \mathrm{H}-2,40$ & 7.40 & 171 & 49.75 & 20.90 & 19.89 & 48.81 & 19.52 & 19.57 & 2.54 \\
\hline $2 \mathrm{H}-2,50$ & 7.50 & 172 & 49.75 & 20.90 & 19.95 & 48.81 & 19.57 & 19.63 & 2.53 \\
\hline $2 \mathrm{H}-2,60$ & 7.60 & 173 & 49.74 & 20.90 & 21.11 & 48.81 & 20.71 & 20.77 & 2.39 \\
\hline $2 \mathrm{H}-2,70$ & 7.70 & 174 & 49.74 & 20.90 & 22.44 & 48.81 & 22.02 & 22.08 & 2.25 \\
\hline $2 \mathrm{H}-2,80$ & 7.80 & 176 & 49.74 & 20.90 & 20.34 & 48.81 & 19.96 & 20.01 & 2.48 \\
\hline $2 \mathrm{H}-2,90$ & 7.90 & 177 & 49.74 & 20.90 & 20.54 & 48.81 & 20.15 & 20.21 & 2.46 \\
\hline $2 \mathrm{H}-2,100$ & 8.00 & 178 & 49.74 & 20.90 & 19.92 & 48.81 & 19.54 & 19.60 & 2.53 \\
\hline $2 \mathrm{H}-2,110$ & 8.10 & 179 & 49.74 & 20.90 & 19.93 & 48.81 & 19.55 & 19.61 & 2.53 \\
\hline $2 \mathrm{H}-2,120$ & 8.20 & 180 & 49.74 & 20.90 & 20.43 & 48.81 & 20.05 & 20.10 & 2.47 \\
\hline $2 \mathrm{H}-2,130$ & 8.30 & 181 & 49.74 & 20.90 & 19.43 & 48.81 & 19.06 & 19.12 & 2.60 \\
\hline $2 \mathrm{H}-2,140$ & 8.40 & 182 & 49.74 & 20.90 & 20.23 & 48.81 & 19.85 & 19.91 & 2.49 \\
\hline $2 \mathrm{H}-3,5$ & 8.55 & 184 & 49.74 & 20.80 & 19.80 & 48.71 & 19.47 & 19.53 & 2.54 \\
\hline $2 \mathrm{H}-3,15$ & 8.65 & 185 & 49.74 & 20.80 & 18.47 & 48.71 & 18.16 & 18.22 & 2.73 \\
\hline $2 \mathrm{H}-3,25$ & 8.75 & 186 & 49.73 & 20.80 & 19.20 & 48.71 & 18.88 & 18.94 & 2.62 \\
\hline $2 \mathrm{H}-3,35$ & 8.85 & 187 & 49.73 & 20.80 & 18.96 & 48.71 & 18.64 & 18.70 & 2.66 \\
\hline $2 \mathrm{H}-3,45$ & 8.95 & 188 & 49.73 & 20.80 & 19.05 & 48.71 & 18.73 & 18.79 & 2.64 \\
\hline $2 \mathrm{H}-3,55$ & 9.05 & 189 & 49.73 & 20.80 & 18.64 & 48.71 & 18.33 & 18.38 & 2.70 \\
\hline $2 \mathrm{H}-3,65$ & 9.15 & 190 & 49.73 & 20.80 & 18.73 & 48.71 & 18.42 & 18.47 & 2.69 \\
\hline $2 \mathrm{H}-3,75$ & 9.25 & 191 & 49.73 & 20.80 & 19.88 & 48.71 & 19.55 & 19.61 & 2.53 \\
\hline $2 \mathrm{H}-3,85$ & 9.35 & 193 & 49.73 & 20.80 & 20.12 & 48.71 & 19.78 & 19.85 & 2.50 \\
\hline $2 \mathrm{H}-3,95$ & 9.45 & 194 & 49.73 & 20.80 & 20.00 & 48.71 & 19.66 & 19.73 & 2.52 \\
\hline $2 \mathrm{H}-3,105$ & 9.55 & 195 & 49.73 & 20.80 & 20.41 & 48.71 & 20.07 & 20.13 & 2.47 \\
\hline $2 \mathrm{H}-3,115$ & 9.65 & 196 & 49.73 & 20.80 & 20.12 & 48.71 & 19.78 & 19.85 & 2.50 \\
\hline $2 \mathrm{H}-3,125$ & 9.75 & 197 & 49.72 & 20.80 & 19.59 & 48.71 & 19.26 & 19.32 & 2.57 \\
\hline $2 \mathrm{H}-3,135$ & 9.85 & 198 & 49.72 & 20.80 & 20.57 & 48.71 & 20.23 & 20.29 & 2.45 \\
\hline $2 \mathrm{H}-3,145$ & 9.95 & 199 & 49.72 & 20.80 & 19.63 & 48.71 & 19.30 & 19.36 & 2.56 \\
\hline $2 \mathrm{H}-4,10$ & 10.10 & 201 & 49.72 & 20.90 & 19.34 & 48.81 & 18.98 & 19.04 & 2.61 \\
\hline $2 \mathrm{H}-4,20$ & 10.20 & 202 & 49.72 & 20.90 & 19.28 & 48.81 & 18.92 & 18.98 & 2.62 \\
\hline $2 \mathrm{H}-4,30$ & 10.30 & 203 & 49.72 & 20.90 & 18.75 & 48.81 & 18.40 & 18.46 & 2.69 \\
\hline $2 \mathrm{H}-4,40$ & 10.40 & 204 & 49.72 & 20.90 & 19.76 & 48.81 & 19.39 & 19.45 & 2.55 \\
\hline $2 \mathrm{H}-4,50$ & 10.50 & 205 & 49.72 & 20.90 & 19.41 & 48.81 & 19.04 & 19.11 & 2.60 \\
\hline $2 \mathrm{H}-4,60$ & 10.60 & 206 & 49.72 & 20.90 & 20.12 & 48.81 & 19.74 & 19.81 & 2.51 \\
\hline $2 \mathrm{H}-4,70$ & 10.70 & 207 & 49.72 & 20.90 & 20.16 & 48.81 & 19.78 & 19.85 & 2.50 \\
\hline $2 \mathrm{H}-4,80$ & 10.80 & 209 & 49.72 & 20.90 & 21.12 & 48.81 & 20.72 & 20.79 & 2.39 \\
\hline $2 \mathrm{H}-4,90$ & 10.90 & 210 & 49.71 & 20.80 & 21.03 & 48.71 & 20.68 & 20.75 & 2.39 \\
\hline $2 \mathrm{H}-4,100$ & 11.00 & 211 & 49.71 & 20.80 & 21.12 & 48.71 & 20.77 & 20.84 & 2.38 \\
\hline $2 \mathrm{H}-4,110$ & 11.10 & 212 & 49.71 & 20.80 & 20.84 & 48.71 & 20.49 & 20.56 & 2.41 \\
\hline $2 \mathrm{H}-4,120$ & 11.20 & 213 & 49.71 & 20.80 & 20.65 & 48.71 & 20.30 & 20.37 & 2.44 \\
\hline $2 \mathrm{H}-4,130$ & 11.30 & 214 & 49.71 & 20.80 & 21.16 & 48.71 & 20.81 & 20.88 & 2.38 \\
\hline $2 \mathrm{H}-4,140$ & 11.40 & 215 & 49.71 & 20.80 & 20.93 & 48.71 & 20.58 & 20.65 & 2.40 \\
\hline $2 \mathrm{H}-5,10$ & 11.60 & 217 & 49.71 & 20.80 & 20.83 & 48.71 & 20.48 & 20.55 & 2.41 \\
\hline $2 \mathrm{H}-5,20$ & 11.70 & 218 & 49.71 & 20.80 & 20.52 & 48.71 & 20.18 & 20.25 & 2.45 \\
\hline $2 \mathrm{H}-5,30$ & 11.80 & 219 & 49.71 & 20.80 & 22.05 & 48.71 & 21.68 & 21.76 & 2.28 \\
\hline $2 \mathrm{H}-5,40$ & 11.90 & 220 & 49.71 & 20.80 & 22.21 & 48.71 & 21.84 & 21.92 & 2.26 \\
\hline $2 \mathrm{H}-5,50$ & 12.00 & 221 & 49.70 & 20.80 & 21.60 & 48.71 & 21.24 & 21.31 & 2.33 \\
\hline $2 \mathrm{H}-5,60$ & 12.10 & 222 & 49.70 & 20.80 & 21.12 & 48.71 & 20.77 & 20.84 & 2.38 \\
\hline $2 \mathrm{H}-5,70$ & 12.20 & 223 & 49.70 & 20.80 & 21.65 & 48.71 & 21.29 & 21.36 & 2.32 \\
\hline $2 \mathrm{H}-5,80$ & 12.30 & 225 & 49.70 & 20.90 & 21.08 & 48.81 & 20.68 & 20.76 & 2.39 \\
\hline $2 \mathrm{H}-5,90$ & 12.40 & 226 & 49.70 & 20.90 & 21.35 & 48.81 & 20.95 & 21.03 & 2.36 \\
\hline $2 \mathrm{H}-5,100$ & 12.50 & 227 & 49.70 & 20.90 & 22.33 & 48.81 & 21.91 & 21.99 & 2.26 \\
\hline $2 \mathrm{H}-5,110$ & 12.60 & 228 & 49.70 & 20.90 & 21.22 & 48.81 & 20.82 & 20.90 & 2.37 \\
\hline $2 \mathrm{H}-5,118$ & 12.68 & 229 & 49.70 & 20.90 & 20.76 & 48.81 & 20.37 & 20.45 & 2.43 \\
\hline $2 \mathrm{H}-6,10$ & 12.83 & 231 & 49.70 & 20.90 & 19.74 & 48.81 & 19.37 & 19.44 & 2.55 \\
\hline $2 \mathrm{H}-6,20$ & 12.93 & 232 & 49.70 & 20.90 & 20.98 & 48.81 & 20.59 & 20.66 & 2.40 \\
\hline $2 \mathrm{H}-6,30$ & 13.03 & 233 & 49.70 & 20.90 & 20.21 & 48.81 & 19.83 & 19.91 & 2.49 \\
\hline $2 \mathrm{H}-6,40$ & 13.13 & 234 & 49.70 & 20.90 & 19.61 & 48.81 & 19.24 & 19.31 & 2.57 \\
\hline $2 \mathrm{H}-6,50$ & 13.23 & 235 & 49.69 & 20.90 & 19.35 & 48.81 & 18.99 & 19.06 & 2.60 \\
\hline $3 \mathrm{H}-1,10$ & 13.60 & 1 & 49.69 & 21.60 & 22.07 & 49.53 & 21.34 & 21.34 & 2.33 \\
\hline $3 \mathrm{H}-1,20$ & 13.70 & 2 & 49.69 & 21.60 & 21.75 & 49.53 & 21.03 & 21.03 & 2.37 \\
\hline $3 \mathrm{H}-1,30$ & 13.80 & 3 & 49.69 & 21.60 & 21.62 & 49.53 & 20.91 & 20.91 & 2.38 \\
\hline $3 \mathrm{H}-1,40$ & 13.90 & 4 & 49.69 & 21.60 & 22.69 & 49.53 & 21.94 & 21.94 & 2.27 \\
\hline
\end{tabular}


Table T8 (continued). (Continued on next page.)

\begin{tabular}{|c|c|c|c|c|c|c|c|c|c|}
\hline $\begin{array}{l}\text { Core, section, } \\
\text { interval }(\mathrm{cm})\end{array}$ & $\begin{array}{l}\text { Depth } \\
\text { (mbsf) }\end{array}$ & $\begin{array}{l}\text { Measurement } \\
\text { number }\end{array}$ & $\begin{array}{l}\text { Temperature- } \\
\text { corrected } \\
\text { seawater } \\
\text { conductivity } \\
(\mathrm{mS} / \mathrm{cm})\end{array}$ & $\begin{array}{l}\text { Sediment } \\
\text { temperature } \\
\left({ }^{\circ} \mathrm{C}\right)\end{array}$ & $\begin{array}{c}\text { Sediment } \\
\text { electrical } \\
\text { conductivity } \\
(\mathrm{mS} / \mathrm{cm})\end{array}$ & $\begin{array}{l}\text { Correction } \\
\text { factor at } 20^{\circ} \mathrm{C} \\
(\mathrm{mS} / \mathrm{cm})\end{array}$ & $\begin{array}{c}\text { Sediment } \\
\text { electrical } \\
\text { conductivity at } \\
20^{\circ} \mathrm{C}(\mathrm{mS} / \mathrm{cm})\end{array}$ & $\begin{array}{l}\text { Drift-corrected } \\
\text { sediment } \\
\text { electrical } \\
\text { conductivity at } \\
20^{\circ} \mathrm{C}(\mathrm{mS} / \mathrm{cm})\end{array}$ & $\begin{array}{l}\text { Formation } \\
\text { factor }\end{array}$ \\
\hline $3 \mathrm{H}-1,50$ & 14.00 & 5 & 49.69 & 21.60 & 22.63 & 49.53 & 21.88 & 21.88 & 2.28 \\
\hline $3 \mathrm{H}-1,60$ & 14.10 & 6 & 49.69 & 21.60 & 22.60 & 49.53 & 21.85 & 21.86 & 2.28 \\
\hline $3 \mathrm{H}-1,70$ & 14.20 & 7 & 49.69 & 21.60 & 22.20 & 49.53 & 21.47 & 21.47 & 2.32 \\
\hline $3 \mathrm{H}-1,80$ & 14.30 & 8 & 49.69 & 21.50 & 23.05 & 49.43 & 22.33 & 22.34 & 2.23 \\
\hline $3 \mathrm{H}-1,90$ & 14.40 & 10 & 49.69 & 21.30 & 23.30 & 49.22 & 22.67 & 22.67 & 2.20 \\
\hline $3 \mathrm{H}-1,100$ & 14.50 & 11 & 49.68 & 21.20 & 22.77 & 49.12 & 22.20 & 22.21 & 2.24 \\
\hline $3 \mathrm{H}-1,110$ & 14.60 & 12 & 49.68 & 21.10 & 22.56 & 49.02 & 22.04 & 22.05 & 2.26 \\
\hline $3 \mathrm{H}-1,120$ & 14.70 & 13 & 49.68 & 21.10 & 22.31 & 49.02 & 21.80 & 21.80 & 2.28 \\
\hline $3 \mathrm{H}-1,130$ & 14.80 & 14 & 49.68 & 21.10 & 23.01 & 49.02 & 22.48 & 22.49 & 2.21 \\
\hline $3 \mathrm{H}-1,140$ & 14.90 & 15 & 49.68 & 21.10 & 22.04 & 49.02 & 21.53 & 21.54 & 2.31 \\
\hline $3 \mathrm{H}-2,10$ & 15.10 & 17 & 49.68 & 21.50 & 21.60 & 49.43 & 20.93 & 20.94 & 2.38 \\
\hline $3 \mathrm{H}-2,20$ & 15.20 & 18 & 49.68 & 21.50 & 22.38 & 49.43 & 21.69 & 21.69 & 2.30 \\
\hline $3 \mathrm{H}-2,30$ & 15.30 & 19 & 49.68 & 21.50 & 22.50 & 49.43 & 21.80 & 21.81 & 2.28 \\
\hline $3 \mathrm{H}-2,40$ & 15.40 & 20 & 49.68 & 21.50 & 22.75 & 49.43 & 22.04 & 22.05 & 2.26 \\
\hline $3 \mathrm{H}-2,50$ & 15.50 & 21 & 49.68 & 21.50 & 22.06 & 49.43 & 21.38 & 21.38 & 2.33 \\
\hline $3 \mathrm{H}-2,60$ & 15.60 & 22 & 49.67 & 21.50 & 22.87 & 49.43 & 22.16 & 22.17 & 2.25 \\
\hline $3 \mathrm{H}-2,70$ & 15.70 & 23 & 49.67 & 21.50 & 22.81 & 49.43 & 22.10 & 22.11 & 2.25 \\
\hline $3 \mathrm{H}-2,80$ & 15.80 & 24 & 49.67 & 21.50 & 22.52 & 49.43 & 21.82 & 21.83 & 2.28 \\
\hline $3 \mathrm{H}-2,90$ & 15.90 & 26 & 49.67 & 21.40 & 22.37 & 49.32 & 21.72 & 21.73 & 2.29 \\
\hline $3 \mathrm{H}-2,100$ & 16.00 & 27 & 49.67 & 21.40 & 21.99 & 49.32 & 21.35 & 21.36 & 2.33 \\
\hline $3 \mathrm{H}-2,110$ & 16.10 & 28 & 49.67 & 21.40 & 21.49 & 49.32 & 20.87 & 20.88 & 2.39 \\
\hline $3 \mathrm{H}-2,120$ & 16.20 & 29 & 49.67 & 21.40 & 21.74 & 49.32 & 21.11 & 21.12 & 2.36 \\
\hline $3 \mathrm{H}-2,130$ & 16.30 & 30 & 49.67 & 21.40 & 20.29 & 49.32 & 19.70 & 19.71 & 2.53 \\
\hline $3 \mathrm{H}-2,140$ & 16.40 & 31 & 49.67 & 21.40 & 21.47 & 49.32 & 20.85 & 20.86 & 2.39 \\
\hline $3 \mathrm{H}-3,10$ & 16.61 & 33 & 49.67 & 21.80 & 22.31 & 49.74 & 21.48 & 21.50 & 2.32 \\
\hline $3 \mathrm{H}-3,20$ & 16.71 & 34 & 49.67 & 21.80 & 21.83 & 49.74 & 21.02 & 21.03 & 2.37 \\
\hline $3 \mathrm{H}-3,30$ & 16.81 & 35 & 49.66 & 21.80 & 21.43 & 49.74 & 20.64 & 20.65 & 2.41 \\
\hline $3 \mathrm{H}-3,40$ & 16.91 & 36 & 49.66 & 21.70 & 21.14 & 49.63 & 20.40 & 20.41 & 2.44 \\
\hline $3 \mathrm{H}-3,50$ & 17.01 & 37 & 49.66 & 21.70 & 20.57 & 49.63 & 19.85 & 19.86 & 2.51 \\
\hline $3 \mathrm{H}-3,60$ & 17.11 & 38 & 49.66 & 21.70 & 21.39 & 49.63 & 20.64 & 20.65 & 2.41 \\
\hline $3 \mathrm{H}-3,70$ & 17.21 & 39 & 49.66 & 21.70 & 21.79 & 49.63 & 21.03 & 21.04 & 2.37 \\
\hline $3 \mathrm{H}-3,80$ & 17.31 & 40 & 49.66 & 21.70 & 22.42 & 49.63 & 21.63 & 21.65 & 2.30 \\
\hline $3 \mathrm{H}-3,90$ & 17.41 & 42 & 49.66 & 21.60 & 21.60 & 49.53 & 20.89 & 20.90 & 2.38 \\
\hline $3 \mathrm{H}-3,100$ & 17.51 & 43 & 49.66 & 21.60 & 21.79 & 49.53 & 21.07 & 21.08 & 2.36 \\
\hline $3 \mathrm{H}-3,110$ & 17.61 & 44 & 49.66 & 21.60 & 21.39 & 49.53 & 20.68 & 20.70 & 2.40 \\
\hline $3 \mathrm{H}-3,120$ & 17.71 & 45 & 49.66 & 21.60 & 21.11 & 49.53 & 20.41 & 20.43 & 2.44 \\
\hline $3 \mathrm{H}-3,130$ & 17.81 & 46 & 49.66 & 21.60 & 21.12 & 49.53 & 20.42 & 20.44 & 2.44 \\
\hline $3 \mathrm{H}-3,140$ & 17.91 & 47 & 49.65 & 21.60 & 20.85 & 49.53 & 20.16 & 20.18 & 2.47 \\
\hline $3 \mathrm{H}-4,10$ & 18.12 & 49 & 49.65 & 21.90 & 22.00 & 49.84 & 21.14 & 21.16 & 2.35 \\
\hline $3 \mathrm{H}-4,20$ & 18.22 & 50 & 49.65 & 21.90 & 21.68 & 49.84 & 20.83 & 20.85 & 2.39 \\
\hline $3 \mathrm{H}-4,30$ & 18.32 & 51 & 49.65 & 21.90 & 21.35 & 49.84 & 20.52 & 20.53 & 2.42 \\
\hline $3 \mathrm{H}-4,40$ & 18.42 & 52 & 49.65 & 21.90 & 20.69 & 49.84 & 19.88 & 19.90 & 2.50 \\
\hline $3 \mathrm{H}-4,50$ & 18.52 & 53 & 49.65 & 21.90 & 21.35 & 49.84 & 20.52 & 20.53 & 2.42 \\
\hline $3 \mathrm{H}-4,60$ & 18.62 & 54 & 49.65 & 21.90 & 21.79 & 49.84 & 20.94 & 20.96 & 2.37 \\
\hline $3 \mathrm{H}-4,70$ & 18.72 & 55 & 49.65 & 21.80 & 21.06 & 49.74 & 20.28 & 20.30 & 2.45 \\
\hline $3 \mathrm{H}-4,80$ & 18.82 & 56 & 49.65 & 21.80 & 21.04 & 49.74 & 20.26 & 20.28 & 2.45 \\
\hline $3 \mathrm{H}-4,90$ & 18.92 & 58 & 49.65 & 21.40 & 20.32 & 49.32 & 19.73 & 19.75 & 2.52 \\
\hline $3 \mathrm{H}-4,100$ & 19.02 & 59 & 49.65 & 21.40 & 21.15 & 49.32 & 20.54 & 20.56 & 2.42 \\
\hline $3 \mathrm{H}-4,110$ & 19.12 & 60 & 49.64 & 21.40 & 20.12 & 49.32 & 19.54 & 19.56 & 2.54 \\
\hline $3 \mathrm{H}-4,120$ & 19.22 & 61 & 49.64 & 21.40 & 19.34 & 49.32 & 18.78 & 18.80 & 2.65 \\
\hline $3 \mathrm{H}-4,130$ & 19.32 & 62 & 49.64 & 21.40 & 20.12 & 49.32 & 19.54 & 19.56 & 2.54 \\
\hline $3 \mathrm{H}-4,140$ & 19.42 & 63 & 49.64 & 21.40 & 20.90 & 49.32 & 20.29 & 20.31 & 2.45 \\
\hline $3 \mathrm{H}-5,10$ & 19.60 & 65 & 49.64 & 21.60 & 20.92 & 49.53 & 20.23 & 20.25 & 2.46 \\
\hline $3 \mathrm{H}-5,20$ & 19.70 & 66 & 49.64 & 21.50 & 16.98 & 49.43 & 16.45 & 16.47 & 3.02 \\
\hline $3 \mathrm{H}-5,30$ & 19.80 & 67 & 49.64 & 21.50 & 17.05 & 49.43 & 16.52 & 16.54 & 3.01 \\
\hline $3 \mathrm{H}-5,40$ & 19.90 & 68 & 49.64 & 21.50 & 13.35 & 49.43 & 12.94 & 12.95 & 3.84 \\
\hline $3 \mathrm{H}-5,50$ & 20.00 & 69 & 49.64 & 21.50 & 16.94 & 49.43 & 16.41 & 16.43 & 3.03 \\
\hline $3 \mathrm{H}-5,60$ & 20.10 & 70 & 49.64 & 21.50 & 16.40 & 49.43 & 15.89 & 15.91 & 3.13 \\
\hline $3 \mathrm{H}-5,70$ & 20.20 & 71 & 49.63 & 21.50 & 16.17 & 49.43 & 15.67 & 15.69 & 3.17 \\
\hline $3 \mathrm{H}-5,80$ & 20.30 & 73 & 49.63 & 21.40 & 17.50 & 49.32 & 16.99 & 17.01 & 2.92 \\
\hline $3 \mathrm{H}-5,90$ & 20.40 & 74 & 49.63 & 21.40 & 16.74 & 49.32 & 16.25 & 16.27 & 3.06 \\
\hline $3 \mathrm{H}-5,100$ & 20.50 & 75 & 49.63 & 21.50 & 15.59 & 49.43 & 15.11 & 15.12 & 3.29 \\
\hline $3 \mathrm{H}-5,110$ & 20.60 & 76 & 49.63 & 21.50 & 14.38 & 49.43 & 13.93 & 13.95 & 3.57 \\
\hline $3 \mathrm{H}-5,120$ & 20.70 & 77 & 49.63 & 21.50 & 13.94 & 49.43 & 13.51 & 13.52 & 3.68 \\
\hline $3 \mathrm{H}-5,130$ & 20.80 & 78 & 49.63 & 21.50 & 14.90 & 49.43 & 14.44 & 14.46 & 3.44 \\
\hline $3 \mathrm{H}-5,140$ & 20.90 & 79 & 49.63 & 21.50 & 8.44 & 49.43 & 8.18 & 8.19 & 6.08 \\
\hline $3 \mathrm{H}-6,10$ & 21.11 & 81 & 49.63 & 21.60 & 17.21 & 49.53 & 16.64 & 16.66 & 2.99 \\
\hline
\end{tabular}


Table T8 (continued).

\begin{tabular}{|c|c|c|c|c|c|c|c|c|c|}
\hline $\begin{array}{l}\text { Core, section, } \\
\text { interval }(\mathrm{cm})\end{array}$ & $\begin{array}{l}\text { Depth } \\
\text { (mbsf) }\end{array}$ & $\begin{array}{l}\text { Measurement } \\
\text { number }\end{array}$ & $\begin{array}{l}\text { Temperature- } \\
\text { corrected } \\
\text { seawater } \\
\text { conductivity } \\
(\mathrm{mS} / \mathrm{cm})\end{array}$ & $\begin{array}{c}\text { Sediment } \\
\text { temperature } \\
\left({ }^{\circ} \mathrm{C}\right)\end{array}$ & $\begin{array}{l}\text { Sediment } \\
\text { electrical } \\
\text { conductivity } \\
(\mathrm{mS} / \mathrm{cm})\end{array}$ & $\begin{array}{l}\text { Correction } \\
\text { factor at } 20^{\circ} \mathrm{C} \\
(\mathrm{mS} / \mathrm{cm})\end{array}$ & $\begin{array}{c}\text { Sediment } \\
\text { electrical } \\
\text { conductivity at } \\
20^{\circ} \mathrm{C}(\mathrm{mS} / \mathrm{cm})\end{array}$ & $\begin{array}{l}\text { Drift-corrected } \\
\text { sediment } \\
\text { electrical } \\
\text { conductivity at } \\
20^{\circ} \mathrm{C}(\mathrm{mS} / \mathrm{cm})\end{array}$ & $\begin{array}{l}\text { Formation } \\
\text { factor }\end{array}$ \\
\hline $3 \mathrm{H}-6,20$ & 21.21 & 82 & 49.63 & 21.60 & 17.93 & 49.53 & 17.34 & 17.36 & 2.87 \\
\hline $3 \mathrm{H}-6,30$ & 21.31 & 83 & 49.62 & 21.60 & 16.68 & 49.53 & 16.13 & 16.15 & 3.08 \\
\hline $3 \mathrm{H}-6,40$ & 21.41 & 84 & 49.62 & 21.50 & 18.83 & 49.43 & 18.25 & 18.27 & 2.72 \\
\hline $3 \mathrm{H}-6,50$ & 21.51 & 85 & 49.62 & 21.50 & 18.44 & 49.43 & 17.87 & 17.89 & 2.78 \\
\hline $3 \mathrm{H}-6,60$ & 21.61 & 86 & 49.62 & 21.50 & 18.24 & 49.43 & 17.67 & 17.70 & 2.81 \\
\hline $3 \mathrm{H}-6,70$ & 21.71 & 87 & 49.62 & 21.50 & 18.42 & 49.43 & 17.85 & 17.87 & 2.78 \\
\hline
\end{tabular}


Table T9. Dissolved oxygen concentrations determined using electrodes, Holes U1367B, U1367E, and U1367F.

\begin{tabular}{|c|c|c|}
\hline $\begin{array}{l}\text { Core, section, } \\
\text { interval }(\mathrm{cm})\end{array}$ & $\begin{array}{l}\text { Depth } \\
\text { (mbsf) }\end{array}$ & $\begin{array}{c}\mathrm{O}_{2} \\
(\mu \mathrm{M})\end{array}$ \\
\hline \multicolumn{3}{|l|}{ 329-U1367B- } \\
\hline $1 \mathrm{H}-1,15$ & 0.15 & 177.0 \\
\hline $1 \mathrm{H}-1,60$ & 0.60 & 159.7 \\
\hline $1 \mathrm{H}-1,100$ & 1.00 & 160.6 \\
\hline $1 \mathrm{H}-1,140$ & 1.40 & 159.8 \\
\hline $1 \mathrm{H}-2,20$ & 1.70 & 149.4 \\
\hline $1 \mathrm{H}-2,80$ & 2.30 & 147.1 \\
\hline $1 \mathrm{H}-2,110$ & 2.60 & 143.8 \\
\hline $1 \mathrm{H}-3,20$ & 3.20 & 145.3 \\
\hline $1 \mathrm{H}-3,50$ & 3.50 & 142.7 \\
\hline $1 \mathrm{H}-3,80$ & 3.80 & 145.4 \\
\hline $1 \mathrm{H}-3,140$ & 4.40 & 142.1 \\
\hline $1 \mathrm{H}-4,20$ & 4.70 & 138.0 \\
\hline $1 \mathrm{H}-4,70$ & 5.20 & 145.3 \\
\hline $2 \mathrm{H}-1,50$ & 6.00 & 138.4 \\
\hline $2 \mathrm{H}-1,90$ & 6.40 & 129.6 \\
\hline $2 \mathrm{H}-1,120$ & 6.70 & 134.2 \\
\hline $2 \mathrm{H}-2,20$ & 7.20 & 131.5 \\
\hline $2 \mathrm{H}-2,140$ & 8.40 & 128.9 \\
\hline $2 \mathrm{H}-3,20$ & 8.70 & 130.1 \\
\hline $2 \mathrm{H}-3,50$ & 9.00 & 122.9 \\
\hline $2 \mathrm{H}-3,80$ & 9.30 & 125.9 \\
\hline $2 \mathrm{H}-3,110$ & 9.60 & 122.8 \\
\hline $2 \mathrm{H}-3,135$ & 9.85 & 128.4 \\
\hline $2 \mathrm{H}-4,20$ & 10.20 & 128.9 \\
\hline $2 \mathrm{H}-4,50$ & 10.50 & 122.0 \\
\hline $2 \mathrm{H}-4,110$ & 11.10 & 122.4 \\
\hline $2 \mathrm{H}-5,20$ & 11.70 & 121.0 \\
\hline $2 \mathrm{H}-5,50$ & 12.00 & 115.2 \\
\hline $2 \mathrm{H}-5,80$ & 12.30 & 117.4 \\
\hline $2 \mathrm{H}-5,110$ & 12.60 & 114.9 \\
\hline $2 \mathrm{H}-6,20$ & 12.92 & 120.3 \\
\hline $2 \mathrm{H}-6,40$ & 13.12 & 114.5 \\
\hline $3 \mathrm{H}-1,20$ & 13.70 & 108.2 \\
\hline $3 \mathrm{H}-1,35$ & 13.85 & 117.7 \\
\hline $3 \mathrm{H}-1,50$ & 14.00 & 110.2 \\
\hline $3 \mathrm{H}-1,82$ & 14.32 & 107.0 \\
\hline $3 \mathrm{H}-1,95$ & 14.45 & 108.8 \\
\hline $3 \mathrm{H}-1,110$ & 14.60 & 111.4 \\
\hline $3 \mathrm{H}-1,115$ & 14.65 & 111.1 \\
\hline $3 \mathrm{H}-1,140$ & 14.90 & 105.0 \\
\hline $3 \mathrm{H}-2,20$ & 15.20 & 101.1 \\
\hline $3 \mathrm{H}-2,35$ & 15.35 & 99.1 \\
\hline $3 \mathrm{H}-2,50$ & 15.50 & 100.5 \\
\hline $3 \mathrm{H}-2,65$ & 15.65 & 97.4 \\
\hline $3 \mathrm{H}-2,95$ & 15.95 & 96.2 \\
\hline $3 \mathrm{H}-2,110$ & 16.10 & 101.2 \\
\hline $3 \mathrm{H}-2,115$ & 16.15 & 96.0 \\
\hline $3 \mathrm{H}-2,140$ & 16.40 & 105.6 \\
\hline $3 \mathrm{H}-3,20$ & 16.70 & 101.2 \\
\hline $3 \mathrm{H}-3,35$ & 16.85 & 100.7 \\
\hline $3 \mathrm{H}-3,50$ & 17.00 & 100.6 \\
\hline $3 \mathrm{H}-3,65$ & 17.15 & 105.0 \\
\hline $3 \mathrm{H}-3,95$ & 17.45 & 101.1 \\
\hline $3 \mathrm{H}-3,110$ & 17.60 & 101.9 \\
\hline $3 \mathrm{H}-3,140$ & 17.90 & 93.5 \\
\hline $3 \mathrm{H}-4,35$ & 18.35 & 97.0 \\
\hline $3 \mathrm{H}-4,50$ & 18.50 & 96.5 \\
\hline $3 \mathrm{H}-4,65$ & 18.65 & 93.2 \\
\hline $3 \mathrm{H}-4,82$ & 18.82 & 97.0 \\
\hline $3 \mathrm{H}-4,95$ & 18.95 & 93.9 \\
\hline
\end{tabular}

\begin{tabular}{|c|c|c|}
\hline $\begin{array}{l}\text { Core, section, } \\
\text { interval }(\mathrm{cm})\end{array}$ & $\begin{array}{l}\text { Depth } \\
\text { (mbsf) }\end{array}$ & $\begin{array}{c}\mathrm{O}_{2} \\
(\mu \mathrm{M})\end{array}$ \\
\hline $3 \mathrm{H}-4,110$ & 19.10 & 94.5 \\
\hline $3 \mathrm{H}-4,140$ & 19.40 & 94.2 \\
\hline $3 \mathrm{H}-5,35$ & 19.85 & 90.2 \\
\hline $3 \mathrm{H}-5,65$ & 20.15 & 87.0 \\
\hline $3 \mathrm{H}-5,95$ & 20.45 & 86.4 \\
\hline $3 \mathrm{H}-6,20$ & 21.20 & 83.7 \\
\hline \multicolumn{3}{|l|}{ 329-U1367C- } \\
\hline $1 \mathrm{H}-1,20$ & 0.20 & 161.7 \\
\hline $1 \mathrm{H}-2,20$ & 1.80 & 151.4 \\
\hline $1 \mathrm{H}-2,130$ & 2.80 & 149.7 \\
\hline $1 \mathrm{H}-3,20$ & 3.30 & 150.0 \\
\hline $1 \mathrm{H}-3,125$ & 4.25 & 142.3 \\
\hline $1 \mathrm{H}-4,40$ & 4.90 & 138.2 \\
\hline $1 \mathrm{H}-4,80$ & 5.30 & 137.0 \\
\hline $1 \mathrm{H}-4,130$ & 5.80 & 153.5 \\
\hline $1 \mathrm{H}-5,35$ & 6.35 & 143.4 \\
\hline $1 \mathrm{H}-1,35$ & 7.55 & 145.9 \\
\hline $2 \mathrm{H}-1,85$ & 8.05 & 135.0 \\
\hline $2 \mathrm{H}-1,125$ & 8.45 & 144.8 \\
\hline $2 \mathrm{H}-2,140$ & 9.10 & 143.0 \\
\hline $2 \mathrm{H}-2,80$ & 9.50 & 149.7 \\
\hline $2 \mathrm{H}-2,130$ & 10.10 & 134.9 \\
\hline $2 \mathrm{H}-3,135$ & 10.55 & 134.5 \\
\hline $2 \mathrm{H}-3,125$ & 11.45 & 135.7 \\
\hline $2 \mathrm{H}-4,30$ & 12.00 & 137.3 \\
\hline $2 \mathrm{H}-4,80$ & 12.50 & 135.1 \\
\hline $2 \mathrm{H}-4,130$ & 13.00 & 133.0 \\
\hline $2 \mathrm{H}-5,30$ & 13.60 & 126.0 \\
\hline $2 \mathrm{H}-5,125$ & 14.45 & 122.2 \\
\hline $2 \mathrm{H}-6,35$ & 15.05 & 130.4 \\
\hline $2 \mathrm{H}-6,125$ & 15.95 & 132.7 \\
\hline $2 \mathrm{H}-1,30$ & 17.00 & 140.3 \\
\hline $3 \mathrm{H}-1,80$ & 17.50 & 123.1 \\
\hline $3 \mathrm{H}-1,130$ & 18.00 & 121.7 \\
\hline $3 \mathrm{H}-2,30$ & 18.50 & 129.8 \\
\hline $3 \mathrm{H}-2,125$ & 19.45 & 119.8 \\
\hline $3 \mathrm{H}-3,125$ & 20.95 & 117.8 \\
\hline $3 \mathrm{H}-4,30$ & 21.60 & 118.3 \\
\hline \multicolumn{3}{|l|}{ 329-U1367E- } \\
\hline $1 \mathrm{H}-1,25$ & 0.25 & 160.7 \\
\hline $1 \mathrm{H}-1,75$ & 0.75 & 152.8 \\
\hline $1 \mathrm{H}-1,100$ & 1.00 & 150.1 \\
\hline $1 \mathrm{H}-1,125$ & 1.25 & 148.9 \\
\hline $1 \mathrm{H}-2,25$ & 1.75 & 147.3 \\
\hline $1 \mathrm{H}-2,50$ & 2.00 & 146.9 \\
\hline $1 \mathrm{H}-2,75$ & 2.25 & 147.5 \\
\hline $1 \mathrm{H}-2,100$ & 2.50 & 142.7 \\
\hline $1 \mathrm{H}-2,125$ & 2.75 & 138.0 \\
\hline $1 \mathrm{H}-3,25$ & 3.25 & 142.9 \\
\hline $1 \mathrm{H}-3,50$ & 3.50 & 147.0 \\
\hline $1 \mathrm{H}-3,75$ & 3.75 & 138.8 \\
\hline $1 \mathrm{H}-3,100$ & 4.00 & 132.7 \\
\hline $1 \mathrm{H}-3,125$ & 4.25 & 133.2 \\
\hline $1 \mathrm{H}-4,25$ & 4.75 & 139.5 \\
\hline $1 \mathrm{H}-4,50$ & 5.00 & 137.6 \\
\hline $1 \mathrm{H}-4,75$ & 5.25 & 133.0 \\
\hline $1 \mathrm{H}-4,100$ & 5.50 & 127.4 \\
\hline $1 \mathrm{H}-4,125$ & 5.75 & 140.9 \\
\hline $1 \mathrm{H}-5,25$ & 6.25 & 135.9 \\
\hline $1 \mathrm{H}-5,50$ & 6.50 & 143.5 \\
\hline
\end{tabular}

\begin{tabular}{|c|c|c|}
\hline $\begin{array}{l}\text { Core, section, } \\
\text { interval }(\mathrm{cm})\end{array}$ & $\begin{array}{l}\text { Depth } \\
\text { (mbsf) }\end{array}$ & $\begin{array}{c}\mathrm{O}_{2} \\
(\mu \mathrm{M})\end{array}$ \\
\hline $2 \mathrm{H}-1,20$ & 7.00 & 136.5 \\
\hline $2 \mathrm{H}-1,50$ & 7.30 & 129.7 \\
\hline $2 \mathrm{H}-1,80$ & 7.60 & 132.0 \\
\hline $2 \mathrm{H}-1,110$ & 7.90 & 127.4 \\
\hline $2 \mathrm{H}-1,130$ & 8.10 & 123.2 \\
\hline $2 \mathrm{H}-2,20$ & 8.50 & 133.3 \\
\hline $2 \mathrm{H}-2,50$ & 8.80 & 128.4 \\
\hline $2 \mathrm{H}-2,80$ & 9.10 & 139.9 \\
\hline $2 \mathrm{H}-2,110$ & 9.40 & 129.2 \\
\hline $2 \mathrm{H}-3,20$ & 9.70 & 136.2 \\
\hline $2 \mathrm{H}-3,80$ & 10.30 & 125.7 \\
\hline $2 \mathrm{H}-3,110$ & 10.60 & 125.7 \\
\hline $2 \mathrm{H}-3,130$ & 10.80 & 125.7 \\
\hline $2 \mathrm{H}-4,20$ & 11.20 & 127.7 \\
\hline $2 \mathrm{H}-4,50$ & 11.50 & 124.8 \\
\hline $2 \mathrm{H}-4,80$ & 11.80 & 122.0 \\
\hline $2 \mathrm{H}-4,110$ & 12.10 & 121.6 \\
\hline $2 \mathrm{H}-4,130$ & 12.30 & 123.7 \\
\hline $2 \mathrm{H}-5,20$ & 12.70 & 123.6 \\
\hline $2 \mathrm{H}-5,50$ & 13.00 & 118.8 \\
\hline $2 \mathrm{H}-5,80$ & 13.30 & 118.7 \\
\hline $2 \mathrm{H}-5,110$ & 13.60 & 118.8 \\
\hline $2 \mathrm{H}-5,130$ & 13.80 & 119.7 \\
\hline $2 \mathrm{H}-6,30$ & 14.30 & 118.6 \\
\hline $2 \mathrm{H}-6,60$ & 14.60 & 118.3 \\
\hline $3 \mathrm{H}-1,20$ & 16.50 & 110.8 \\
\hline $3 \mathrm{H}-1,50$ & 16.80 & 115.6 \\
\hline $3 \mathrm{H}-1,80$ & 17.10 & 111.1 \\
\hline $3 \mathrm{H}-1,110$ & 17.40 & 113.7 \\
\hline $3 \mathrm{H}-1,130$ & 17.60 & 119.0 \\
\hline $3 \mathrm{H}-2,20$ & 18.00 & 114.4 \\
\hline $3 \mathrm{H}-2,60$ & 18.60 & 112.0 \\
\hline $3 \mathrm{H}-2,110$ & 18.90 & 117.7 \\
\hline $3 \mathrm{H}-2,130$ & 19.10 & 117.0 \\
\hline $3 \mathrm{H}-3,20$ & 19.50 & 110.7 \\
\hline $3 \mathrm{H}-3,50$ & 19.80 & 113.5 \\
\hline $3 \mathrm{H}-3,80$ & 20.10 & 110.2 \\
\hline $3 \mathrm{H}-3,110$ & 20.40 & 111.0 \\
\hline $3 \mathrm{H}-3,130$ & 20.60 & 117.5 \\
\hline $3 \mathrm{H}-4,80$ & 21.60 & 108.8 \\
\hline $3 \mathrm{H}-4,110$ & 21.90 & 105.1 \\
\hline $3 \mathrm{H}-4,130$ & 22.10 & 100.3 \\
\hline $3 \mathrm{H}-5,20$ & 22.50 & 109.7 \\
\hline $3 \mathrm{H}-5,40$ & 22.70 & 111.2 \\
\hline $3 \mathrm{H}-5,60$ & 22.90 & 107.3 \\
\hline $3 \mathrm{H}-5,80$ & 23.10 & 106.8 \\
\hline $3 \mathrm{H}-5,100$ & 23.30 & 107.0 \\
\hline $3 \mathrm{H}-6,15$ & 23.95 & 105.6 \\
\hline $3 \mathrm{H}-6,25$ & 24.05 & 105.8 \\
\hline \multicolumn{3}{|l|}{ 329-U1367F- } \\
\hline 1R-1, 10 & 17.10 & 109.5 \\
\hline $1 \mathrm{R}-1,20$ & 17.20 & 108.4 \\
\hline $1 \mathrm{R}-2,10$ & 17.45 & 106.6 \\
\hline $1 \mathrm{R}-3,20$ & 17.55 & 106.7 \\
\hline $1 \mathrm{R}-3,30$ & 17.65 & 107.4 \\
\hline $2 \mathrm{R}-1,40$ & 17.75 & 104.3 \\
\hline $2 \mathrm{R}-1,60$ & 17.95 & 103.1 \\
\hline $2 \mathrm{R}-1,80$ & 18.15 & 102.0 \\
\hline $2 \mathrm{R}-1,100$ & 18.25 & 90.4 \\
\hline
\end{tabular}


Table T10. Dissolved oxygen concentrations determined using optodes, Hole U1367B.

\begin{tabular}{|c|c|c|}
\hline $\begin{array}{l}\text { Core, section, } \\
\text { interval }(\mathrm{cm})\end{array}$ & $\begin{array}{l}\text { Depth } \\
\text { (mbsf) }\end{array}$ & $\begin{array}{c}\mathrm{O}_{2} \\
(\mu \mathrm{M})\end{array}$ \\
\hline \multicolumn{3}{|l|}{ 329-U1367B- } \\
\hline $1 \mathrm{H}-1,5$ & 0.05 & 159.1 \\
\hline $1 \mathrm{H}-1,10$ & 0.10 & 156.4 \\
\hline $1 \mathrm{H}-1,20$ & 0.20 & 153.4 \\
\hline $1 \mathrm{H}-1,30$ & 0.30 & 150.8 \\
\hline $1 \mathrm{H}-1,40$ & 0.40 & 146.3 \\
\hline $1 \mathrm{H}-1,50$ & 0.50 & 144.3 \\
\hline $1 \mathrm{H}-1,70$ & 0.70 & 140.5 \\
\hline $1 \mathrm{H}-1,80$ & 0.80 & 138.5 \\
\hline $1 \mathrm{H}-1,110$ & 1.10 & 136.5 \\
\hline $1 \mathrm{H}-1,130$ & 1.30 & 135.0 \\
\hline $1 \mathrm{H}-2,10$ & 1.60 & 133.5 \\
\hline $1 \mathrm{H}-2,40$ & 1.90 & 132.7 \\
\hline $1 \mathrm{H}-2,70$ & 2.20 & 131.2 \\
\hline $1 \mathrm{H}-2,100$ & 2.50 & 130.5 \\
\hline $1 \mathrm{H}-2,130$ & 2.80 & 129.8 \\
\hline $1 \mathrm{H}-3,30$ & 3.30 & 128.6 \\
\hline $1 \mathrm{H}-3,80$ & 3.80 & 127.6 \\
\hline $1 \mathrm{H}-3,130$ & 4.30 & 126.8 \\
\hline $1 \mathrm{H}-4,30$ & 4.80 & 125.7 \\
\hline $1 \mathrm{H}-4,60$ & 5.10 & 125.6 \\
\hline $1 \mathrm{H}-4,80$ & 5.30 & 133.2 \\
\hline $2 \mathrm{H}-1,10$ & 5.60 & 131.0 \\
\hline $2 \mathrm{H}-1,20$ & 5.70 & 124.3 \\
\hline $2 \mathrm{H}-1,30$ & 5.80 & 124.3 \\
\hline $2 \mathrm{H}-1,80$ & 6.30 & 122.9 \\
\hline $2 \mathrm{H}-1,130$ & 6.80 & 120.6 \\
\hline $2 \mathrm{H}-2,30$ & 7.30 & 118.5 \\
\hline $2 \mathrm{H}-2,80$ & 7.80 & 116.1 \\
\hline $2 \mathrm{H}-2,130$ & 8.30 & 115.2 \\
\hline $2 \mathrm{H}-3,30$ & 8.80 & 112.8 \\
\hline $2 \mathrm{H}-3,80$ & 9.30 & 110.6 \\
\hline $2 \mathrm{H}-3,130$ & 9.80 & 109.2 \\
\hline $2 \mathrm{H}-4,30$ & 10.30 & 107.3 \\
\hline $2 \mathrm{H}-4,80$ & 10.80 & 105.2 \\
\hline $2 \mathrm{H}-4,130$ & 11.30 & 104.0 \\
\hline $2 \mathrm{H}-5,30$ & 11.80 & 103.4 \\
\hline $2 \mathrm{H}-5,80$ & 12.30 & 102.0 \\
\hline $2 \mathrm{H}-6,10$ & 12.80 & 101.2 \\
\hline $2 \mathrm{H}-6,40$ & 13.10 & 100.8 \\
\hline $3 \mathrm{H}-1,30$ & 13.80 & 100.3 \\
\hline $3 \mathrm{H}-1,80$ & 14.30 & 97.6 \\
\hline $3 \mathrm{H}-1,130$ & 14.80 & 96.7 \\
\hline $3 \mathrm{H}-2,30$ & 15.30 & 95.6 \\
\hline $3 \mathrm{H}-2,80$ & 15.80 & 94.2 \\
\hline $3 \mathrm{H}-2,130$ & 16.30 & 93.3 \\
\hline $3 \mathrm{H}-4,80$ & 18.80 & 89.7 \\
\hline
\end{tabular}


Table T11. Dissolved hydrogen measured by headspace gas method, Site U1367.

\begin{tabular}{|c|c|c|}
\hline $\begin{array}{l}\text { Core, section, } \\
\text { interval }(\mathrm{cm})\end{array}$ & $\begin{array}{l}\text { Depth } \\
\text { (mbsf) }\end{array}$ & $\begin{array}{c}\mathrm{H}_{2} \\
(\mathrm{nM})\end{array}$ \\
\hline \multicolumn{3}{|l|}{ 329-U1367C- } \\
\hline $1 \mathrm{H}-1,60-70$ & 0.70 & $\mathrm{BD}$ \\
\hline $1 \mathrm{H}-1,110-120$ & 1.20 & $\mathrm{BD}$ \\
\hline $1 \mathrm{H}-1,135-140$ & 1.40 & BD \\
\hline $1 \mathrm{H}-2,60-70$ & 2.20 & BD \\
\hline $1 \mathrm{H}-2,110-120$ & 2.70 & $\mathrm{BD}$ \\
\hline $1 \mathrm{H}-3,60-70$ & 3.70 & $\mathrm{BD}$ \\
\hline $1 \mathrm{H}-3,110-120$ & 4.20 & $\mathrm{BD}$ \\
\hline $1 \mathrm{H}-3,135-140$ & 4.40 & $\mathrm{BD}$ \\
\hline $1 \mathrm{H}-4,60-70$ & 5.20 & 9.2 \\
\hline $1 \mathrm{H}-4,140-150$ & 6.00 & 5.4 \\
\hline $1 \mathrm{H}-5,60-70$ & 6.70 & 5.0 \\
\hline $1 \mathrm{H}-5,90-95$ & 7.00 & $\mathrm{BD}$ \\
\hline $2 \mathrm{H}-1,60-70$ & 7.90 & $\mathrm{BD}$ \\
\hline $2 \mathrm{H}-1,110-120$ & 8.40 & 11.7 \\
\hline $2 \mathrm{H}-1,145-150$ & 8.70 & 5.3 \\
\hline $2 \mathrm{H}-2,60-70$ & 9.40 & 36.4 \\
\hline $2 \mathrm{H}-2,110-120$ & 9.90 & 20.3 \\
\hline $2 \mathrm{H}-3,60-70$ & 10.90 & 4.1 \\
\hline $2 \mathrm{H}-3,110-120$ & 11.40 & 11.8 \\
\hline $2 \mathrm{H}-3,145-150$ & 11.70 & $\mathrm{BD}$ \\
\hline $2 \mathrm{H}-4,60-70$ & 12.40 & 19.7 \\
\hline $2 \mathrm{H}-4,110-120$ & 12.90 & BD \\
\hline $2 \mathrm{H}-5,60-70$ & 13.90 & 5.3 \\
\hline $2 \mathrm{H}-5,110-120$ & 14.40 & $\mathrm{BD}$ \\
\hline $2 \mathrm{H}-5,145-150$ & 14.70 & 5.2 \\
\hline $2 \mathrm{H}-6,60-70$ & 15.40 & 2.3 \\
\hline $2 \mathrm{H}-6,110-120$ & 15.90 & $\mathrm{BD}$ \\
\hline $2 \mathrm{H}-7,50-60$ & 16.80 & $\mathrm{BD}$ \\
\hline $3 \mathrm{H}-1,50-60$ & 17.30 & 3.1 \\
\hline $3 \mathrm{H}-1,110-120$ & 17.90 & $\mathrm{BD}$ \\
\hline $3 \mathrm{H}-2,0-5$ & 18.30 & $\mathrm{BD}$ \\
\hline $3 \mathrm{H}-2,60-70$ & 18.90 & 22.6 \\
\hline $3 \mathrm{H}-2,110-120$ & 19.40 & 11.8 \\
\hline $3 \mathrm{H}-3,60-70$ & 20.40 & 5.9 \\
\hline $3 \mathrm{H}-3,110-120$ & 20.90 & 7.8 \\
\hline $3 \mathrm{H}-4,60-70$ & 21.90 & 11.2 \\
\hline $3 \mathrm{H}-4,90-100$ & 22.20 & 3.0 \\
\hline $3 \mathrm{H}-6,0-5$ & 24.30 & $\mathrm{BD}$ \\
\hline \multicolumn{3}{|l|}{ 329-U1367D- } \\
\hline $2 \mathrm{H}-4,50-60$ & 12.50 & $\mathrm{BD}$ \\
\hline $3 \mathrm{H}-1,80-90$ & 17.80 & 8.9 \\
\hline $3 \mathrm{H}-2,10-20$ & 18.60 & 3.2 \\
\hline $3 \mathrm{H}-3,10-20$ & 20.10 & 6.7 \\
\hline $3 \mathrm{H}-3,135-140$ & 21.30 & BD \\
\hline $3 \mathrm{H}-4,80-90$ & 22.30 & 4.3 \\
\hline $3 \mathrm{H}-4,135-140$ & 22.80 & $\mathrm{BD}$ \\
\hline $3 \mathrm{H}-5,80-90$ & 23.80 & $\mathrm{BD}$ \\
\hline $3 \mathrm{H}-5,135-140$ & 24.30 & $\mathrm{BD}$ \\
\hline $3 \mathrm{H}-6,10-20$ & 24.60 & 2.3 \\
\hline
\end{tabular}

$\mathrm{BD}=$ below detection $(<2.2 \mathrm{nM})$. 
Table T12. Interstitial fluid chemistry, Site U1367. (Continued on next page.)

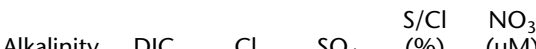

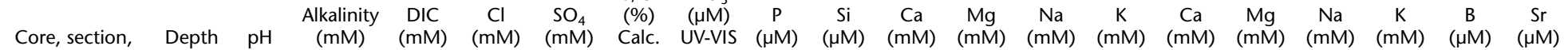

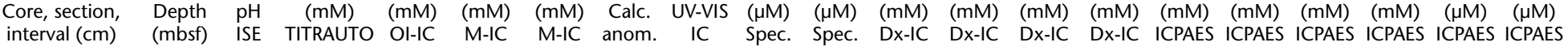

\begin{tabular}{|c|c|c|c|c|c|c|c|c|c|c|c|c|c|c|c|c|c|c|c|c|}
\hline \\
\hline \multicolumn{21}{|l|}{$\begin{array}{c}329-U 1367 C- \\
1 \mathrm{H}-1,0-10\end{array}$} \\
\hline $1 \mathrm{H}-1,50-60$ & 0.55 & 7.59 & 2.786 & 2.766 & 555.37 & 27.23 & -5.06 & 36.06 & 2.06 & 319 & 10.6 & 49.8 & 482 & 12.4 & 10.7 & 49.9 & 471.2 & 11.6 & 500 & 92.4 \\
\hline $1 \mathrm{H}-1,100-110$ & 1.05 & 7.57 & 2.817 & 2.781 & 555.23 & 27.21 & -5.14 & 35.99 & 1.62 & 246 & 10.5 & 49.6 & 480 & 12.3 & 10.2 & 52.3 & 473.7 & 10.7 & 508 & 92.9 \\
\hline $1 \mathrm{H}-1,140-150$ & 1.45 & 7.46 & 2.914 & 2.791 & 553.60 & 27.20 & -4.89 & - & 1.60 & 327 & 10.6 & 49.3 & 478 & - & 10.8 & 51.6 & 478.5 & 11.3 & 485 & 92.2 \\
\hline $1 \mathrm{H}-2,0-10$ & 1.55 & 7.50 & 2.910 & 2.768 & 555.70 & 27.24 & -5.12 & 36.68 & 1.26 & 262 & 10.6 & 49.4 & 482 & - & 10.6 & 50.4 & 468.5 & 10.7 & 494 & 93.0 \\
\hline $1 \mathrm{H}-2,50-60$ & 2.05 & 7.67 & 2.915 & 2.809 & 557.02 & 27.27 & -5.21 & 36.53 & 1.28 & 287 & 10.4 & 49.8 & 481 & 12.3 & 11.0 & 49.5 & 484.0 & 11.8 & 501 & 92.7 \\
\hline $1 \mathrm{H}-2,100-110$ & 2.55 & 7.60 & 2.808 & 2.803 & 555.94 & 27.26 & -5.07 & 36.24 & 1.07 & 280 & 10.7 & 49.6 & 479 & 12.1 & 10.9 & 51.3 & 488.6 & 12.3 & 516 & 93.8 \\
\hline $1 \mathrm{H}-3,0-10$ & 3.05 & 7.67 & 2.876 & 2.883 & 555.94 & 27.16 & -5.43 & 36.25 & 1.15 & 262 & 10.6 & 49.2 & 475 & 12.1 & 10.6 & 50.6 & 480.5 & 11.9 & 506 & 93.1 \\
\hline $1 \mathrm{H}-3,50-60$ & 3.55 & 7.56 & 2.815 & 2.807 & 555.85 & 26.54 & -7.55 & 37.09 & 1.16 & 270 & 10.5 & 49.5 & 479 & 12.0 & 10.3 & 50.2 & 487.3 & 12.3 & 519 & 94.0 \\
\hline $1 \mathrm{H}-3,100-110$ & 4.05 & 7.66 & 2.883 & 2.842 & 555.53 & 26.42 & -7.94 & 36.84 & 1.19 & 265 & 10.7 & 49.3 & 480 & 11.8 & 10.6 & 49.9 & 483.9 & 12.2 & 509 & 93.5 \\
\hline $1 \mathrm{H}-3,140-150$ & 4.45 & 7.53 & 3.038 & 2.948 & 556.32 & 26.83 & -6.63 & - & 0.82 & 285 & 10.7 & 49.1 & 483 & 12.0 & 10.5 & 49.8 & 477.3 & 12.1 & 541 & 94.0 \\
\hline $1 \mathrm{H}-4,0$ & 4.55 & 7.59 & 2.950 & 2.953 & 556.59 & 26.59 & -7.50 & 36.81 & 1.09 & 256 & 10.7 & 49.2 & 482 & 11.9 & 10.4 & 49.7 & 470.6 & & 521 & 93.3 \\
\hline $1 \mathrm{H}-4,5 \mathrm{C}$ & 5.05 & 7.61 & 2.961 & 2.937 & 557.04 & 26.94 & -6.38 & 36.66 & 0.93 & 286 & 10.8 & 49.4 & 482 & 11.8 & 10.5 & 49.6 & 471.8 & 11.7 & 532 & 93.3 \\
\hline $1 \mathrm{H}-4,100-110$ & 5.55 & 7.70 & 2.575 & 2.534 & 556.12 & 26.86 & -6.49 & 36.80 & 0.89 & 237 & 10.4 & 51.3 & 482 & 11.4 & 10.4 & 52.3 & 474.9 & 11.1 & 480 & 91.8 \\
\hline $1 \mathrm{H}-5, \mathrm{O}$ & 6.05 & 7.63 & 2.565 & 2.546 & 557.17 & 27.53 & -4.36 & 36.74 & 0.80 & 286 & 10.2 & 52.2 & 478 & 10.9 & 10.5 & 50.1 & 474.7 & & 441 & 92.0 \\
\hline $1 \mathrm{H}-5,50-60$ & 6.55 & 7.57 & 2.588 & 2.568 & 557.30 & 27.37 & -4.91 & 36.88 & 0.91 & 308 & 10.4 & 51.9 & 478 & 11.1 & 10.1 & 52.4 & 474.3 & 10.8 & 463 & 92.7 \\
\hline $1 \mathrm{H}-5,95-105$ & 7.00 & 7.54 & 2.709 & 2.653 & 557.67 & 27.59 & -4.21 & - & 0.72 & 263 & 10.3 & 52.3 & 480 & 10.8 & 10.1 & 50.7 & 478.4 & 11.1 & 452 & 92.9 \\
\hline $2 \mathrm{H}-1,0$ & 7.25 & 7.52 & 2.542 & 2.541 & 558.96 & 27.50 & -4.76 & 33.30 & 1.33 & 275 & 10.4 & 51.9 & 479 & 11.0 & 10.2 & 52.3 & 478.6 & 11.0 & 464 & 93.0 \\
\hline $2 \mathrm{H}-1,5 \mathrm{C}$ & 7.75 & 7.66 & 2.525 & 2.496 & 559.30 & 27.59 & -4.51 & 36.45 & 0.73 & 297 & 10.1 & 52. & 479 & - & 10.3 & 52.2 & 474.0 & 11.1 & 472 & 93.4 \\
\hline $2 \mathrm{H}-1,100-110$ & 8.25 & 7.52 & 2.636 & 2.554 & 559.43 & 27.31 & -5.49 & 42.15 & 0.51 & 257 & 10.4 & 51.4 & 479 & - & 10.5 & 52.2 & 480.2 & 11.3 & 502 & 93.8 \\
\hline $2 \mathrm{H}-1,1$ & 8.65 & 7.50 & 2.759 & 2.714 & 559.18 & 27.25 & -5.67 & - & 0.75 & 263 & 10.6 & 50.7 & 47 & - & 10.5 & 51.9 & 474.2 & 10.7 & 518 & 94.3 \\
\hline $2 \mathrm{H}-2,0-10$ & 8.75 & 7.64 & 2.641 & 2.600 & 558.45 & 27.75 & -3.81 & 37.13 & 0.72 & 412 & 10.6 & 52. & 484 & - & 10.6 & 48.8 & 473.7 & 11.2 & 453 & 93.1 \\
\hline $2 \mathrm{H}-2,50-60$ & 9.25 & 7.68 & 2.678 & 2.638 & 558.99 & 27.91 & -3.34 & 36.95 & 0.61 & 259 & 10.4 & 53.1 & 480 & - & 10.7 & 51.0 & 477.5 & 10.9 & 431 & 92.6 \\
\hline $2 \mathrm{H}-2,1 \mathrm{C}$ & 9.75 & 7.71 & 2.844 & 2.834 & 557.60 & 27.78 & -3.55 & 36.95 & 0.73 & 276 & 14 & 53.0 & & - & .4 & 52.8 & 471.5 & 10.6 & 436 & 92.7 \\
\hline $2 \mathrm{H}-3,0-10$ & 10.25 & 7.66 & 2.650 & 2.658 & 558.71 & 27.91 & -3.29 & 37.01 & 0.54 & 223 & 10.3 & 52.4 & 475 & - & 10.5 & 52.6 & 471.1 & 10.5 & 453 & 93.0 \\
\hline $2 \mathrm{H}-3,50-60$ & 10.75 & 7.66 & 2.700 & 2.679 & 559.82 & 27.85 & -3.70 & 37.31 & 0.68 & 288 & 10.5 & - & 483 & - & 10.0 & 51.9 & 466.6 & 10.2 & 442 & 92.0 \\
\hline $2 \mathrm{H}-3,1$ & 1.25 & 7.63 & 2.640 & 2.641 & 560.19 & 27.94 & -3.43 & 37.25 & 0.39 & 241 & 10.3 & 51.8 & 476 & - & 10.5 & 52.5 & 489.7 & 10.8 & 447 & 92.6 \\
\hline $2 \mathrm{H}-3,140-150$ & 11.65 & 7.56 & 2.750 & 2.721 & 561.00 & 27.76 & -4.19 & - & 0.60 & 281 & 11.0 & 51.4 & 484 & - & - & - & - & - & - & - \\
\hline $2 \mathrm{H}-4,0-10$ & 11.75 & 7.61 & 2.600 & 2.625 & 560.15 & 28.02 & -3.16 & 36.81 & 0.50 & 282 & 10.6 & 52.5 & 482 & - & 10.7 & 52.4 & 482.8 & 10.7 & 446 & 92.7 \\
\hline $2 \mathrm{H}-4,50-60$ & & 7.62 & & 2.665 & 560.05 & 28.04 & -3.07 & 36.95 & - & - & & & & - & & & & & 447 & 92.7 \\
\hline $2 \mathrm{H}-4,100-11$ & 12.75 & 7.68 & 2.577 & 2.538 & 558.83 & 27.90 & -3.34 & 36.45 & 0.48 & 284 & 10.8 & 51.6 & 48 & - & 10.5 & 52.5 & 480.4 & 10.8 & 443 & 92.5 \\
\hline $2 \mathrm{H}-5,0-10$ & 13.25 & 7.63 & 2.666 & 2.625 & 558.93 & 27.74 & -3.91 & 36.64 & 0.59 & 279 & 10.7 & 52.7 & 486 & - & 10.9 & 52.5 & 481.1 & 11.1 & 466 & 93.1 \\
\hline $2 \mathrm{H}-5,50-60$ & & 7.61 & 2.590 & 2.611 & 560.52 & 27.66 & -4.46 & 36.78 & 0.86 & 260 & & & & - & & & & & 490 & 93.8 \\
\hline $2 \mathrm{H}-5,1$ & 14.25 & 7.65 & .590 & 2.564 & 560.34 & 27.84 & -3.83 & 36.77 & 0.60 & 272 & 10.8 & 52.0 & 484 & - & 10.5 & 49.2 & 469.4 & 11.4 & 486 & 94.1 \\
\hline $2 \mathrm{H}-5,140-150$ & 14.65 & 7.52 & 2.711 & 2.675 & 557.59 & 27.72 & -3.77 & - & 0.66 & 276 & 10.7 & 50.0 & 476 & - & 10.7 & 50.2 & 483.1 & 11.4 & 489 & 93.8 \\
\hline $2 \mathrm{H}-6,0-10$ & 14.75 & 7.57 & 2.629 & 2.692 & - & - & - & 37.04 & 0.98 & 278 & 11.0 & - & 48 & - & 10.7 & 50.1 & 476.5 & 11 & 486 & 93.7 \\
\hline $2 \mathrm{H}-6,5$ & .25 & 7.63 & 2.6 & 2.685 & 560.83 & 27.53 & -4.98 & 36.91 & 0.6 & 25 & 11.0 & & & - & 10.7 & & 475.5 & & 496 & 94.0 \\
\hline $2 \mathrm{H}-6,100-110$ & 15.75 & 7.66 & 2.631 & 2.589 & 560.22 & 27.49 & -5.01 & 37.06 & 0.58 & 273 & 10.8 & 50.4 & 484 & - & 11.0 & 50.0 & 493.9 & 11.8 & 479 & 92.8 \\
\hline $2 \mathrm{H}-7,0-10$ & 16.25 & 7.64 & 2.613 & 2.594 & 560.57 & 27.58 & -4.76 & 37.17 & 0.69 & 263 & & 50. & 484 & - & 11.1 & 49.8 & 486.5 & 11 & 476 & 92.4 \\
\hline $3 \mathrm{H}-1,0$ & 6.75 & 7.68 & 2.581 & 2.547 & 560.73 & 27.48 & -5.1 & 36.47 & 0.7 & 28 & 10 & 49 & 48 & - & 10.9 & 49 & 481.0 & 11 & 482 & 93.3 \\
\hline $2 \mathrm{H}-7,60-70$ & 5.85 & 7.66 & 2.64 & 2.663 & 561.10 & 27.57 & -4.86 & 37.08 & 0.6 & 25 & 10.9 & 51.2 & 488 & - & 11.1 & 50.7 & 485.7 & 11.6 & 484 & 92.9 \\
\hline $3 \mathrm{H}-1,50-60$ & 17.25 & 7.67 & 2.533 & 2.526 & 559.92 & 27.32 & -5.54 & 36.53 & 0.58 & 306 & - & - & - & - & 10.0 & 47.5 & 452.0 & 11.2 & 481 & 93.0 \\
\hline & & 7.61 & & & & & & & & 28 & & & & - & & & & & 488 & \\
\hline $3 \mathrm{H}-2,0-10$ & 18.25 & 7.62 & 2.479 & 2.504 & 560.21 & 27.51 & -4.93 & 37.22 & 0.79 & 289 & 10.9 & 50. & 493 & - & 10.8 & 49.5 & 482.1 & 11.4 & 490 & 93.5 \\
\hline $3 \mathrm{H}-2,50-60$ & 18.75 & 7.64 & 2.510 & 2.486 & 561.52 & 27.27 & -5.98 & 36.67 & 0.60 & 276 & 10.8 & 49.4 & 489 & - & 11.0 & 51.1 & 479.9 & 11.4 & 492 & 93.7 \\
\hline & & 7.62 & & & & 27.21 & & 36.66 & 0.61 & 277 & 10.8 & & & - & 10.8 & 49.7 & 486.9 & & 495 & \\
\hline $3 \mathrm{H}-2,140-150$ & 19.65 & 7.53 & 2.663 & 2.610 & 561.11 & 27.22 & -6.08 & - & 0.71 & 336 & 10.9 & 48.7 & 486 & - & 10.8 & 50.1 & & 11.7 & 502 & \\
\hline $3 \mathrm{H}-3,0-10$ & 19.75 & 7.55 & 2.531 & 2.592 & 561.16 & 27.07 & -6.63 & 36.97 & 0.95 & 292 & 10.9 & & 489 & - & 10.8 & 48.7 & 478.5 & 11.4 & 516 & 01 \\
\hline
\end{tabular}


Table T12 (continued).

\begin{tabular}{|c|c|c|c|c|c|c|c|c|c|c|c|c|c|c|c|c|c|c|c|c|}
\hline $\begin{array}{l}\text { Core, section, } \\
\text { interval }(\mathrm{cm})\end{array}$ & $\begin{array}{l}\text { Depth } \\
\text { (mbsf) }\end{array}$ & $\begin{array}{l}\mathrm{pH} \\
\text { ISE }\end{array}$ & $\begin{array}{l}\text { Alkalinity } \\
\text { (mM) } \\
\text { TITRAUTO }\end{array}$ & $\begin{array}{c}\mathrm{DIC} \\
(\mathrm{mM}) \\
\mathrm{OI}-\mathrm{IC}\end{array}$ & $\begin{array}{c}\mathrm{Cl} \\
(\mathrm{mM}) \\
\mathrm{M}-\mathrm{IC}\end{array}$ & $\begin{array}{c}\mathrm{SO}_{4} \\
(\mathrm{mM}) \\
\mathrm{M}-\mathrm{IC}\end{array}$ & $\begin{array}{l}\mathrm{S} / \mathrm{Cl} \\
(\%) \\
\text { Calc. } \\
\text { anom. }\end{array}$ & $\begin{array}{c}\mathrm{NO}_{3} \\
(\mu \mathrm{M}) \\
\text { UV-VIS } \\
\text { IC }\end{array}$ & $\begin{array}{c}P \\
(\mu \mathrm{M}) \\
\text { Spec. }\end{array}$ & $\begin{array}{c}\text { Si } \\
(\mu \mathrm{M}) \\
\text { Spec. }\end{array}$ & $\begin{array}{c}\mathrm{Ca} \\
(\mathrm{mM}) \\
\mathrm{Dx}-\mathrm{IC}\end{array}$ & $\begin{array}{c}\mathrm{Mg} \\
(\mathrm{mM}) \\
\mathrm{Dx}-\mathrm{IC}\end{array}$ & $\begin{array}{c}\mathrm{Na} \\
(\mathrm{mM}) \\
\mathrm{Dx}-\mathrm{IC}\end{array}$ & $\begin{array}{c}\mathrm{K} \\
(\mathrm{mM}) \\
\mathrm{Dx}-\mathrm{IC}\end{array}$ & $\begin{array}{c}\mathrm{Ca} \\
(\mathrm{mM}) \\
\text { ICPAES }\end{array}$ & $\begin{array}{c}\mathrm{Mg} \\
(\mathrm{mM}) \\
\text { ICPAES }\end{array}$ & $\begin{array}{c}\mathrm{Na} \\
(\mathrm{mM}) \\
\text { ICPAES }\end{array}$ & $\begin{array}{c}\mathrm{K} \\
(\mathrm{mM}) \\
\text { ICPAES }\end{array}$ & $\begin{array}{c}\text { B } \\
(\mu \mathrm{M}) \\
\text { ICPAES }\end{array}$ & $\begin{array}{c}\mathrm{Sr} \\
(\mu \mathrm{M}) \\
\text { ICPAES }\end{array}$ \\
\hline $3 \mathrm{H}-3,50-60$ & 20.25 & 7.62 & 2.536 & 2.501 & 561.60 & 27.21 & -6.19 & 37.11 & 0.72 & 281 & 10.7 & - & 488 & - & 10.4 & 49.3 & 472.5 & 11.5 & 515 & 93.7 \\
\hline $3 \mathrm{H}-3,100-110$ & 20.75 & 7.55 & 2.577 & 2.563 & 559.10 & 27.51 & -4.76 & 36.45 & 0.74 & 284 & 10.5 & - & 484 & - & 10.6 & 48.8 & 478.3 & 11.4 & 519 & 92.4 \\
\hline $3 \mathrm{H}-4,0-10$ & 21.25 & 7.59 & 2.741 & 2.763 & 561.19 & 27.22 & -6.08 & 36.61 & 0.91 & 292 & - & 48.8 & 484 & - & 10.7 & 49.2 & 479.9 & 11.5 & 476 & 92.4 \\
\hline $3 \mathrm{H}-4,50-60$ & 21.75 & 7.70 & 2.785 & 2.762 & 560.97 & 27.23 & -6.03 & 36.43 & 0.91 & 296 & 10.7 & 49.4 & 485 & - & 10.4 & 53.0 & 478.2 & 10.6 & 496 & 93.2 \\
\hline $3 \mathrm{H}-4,100-110$ & 22.25 & 7.68 & 2.768 & 2.724 & 560.24 & 27.23 & -5.91 & 36.83 & 1.19 & 295 & 10.6 & 49.6 & 478 & - & 10.8 & 49.6 & 480.6 & 11.5 & 478 & 92.8 \\
\hline $3 \mathrm{H}-5,140-150$ & 24.15 & 7.63 & 2.676 & 2.596 & 558.63 & 27.82 & -3.59 & - & 0.83 & 295 & 10.6 & 50.0 & 479 & - & 10.7 & 49.1 & 474.2 & 11.4 & 486 & 93.3 \\
\hline $3 \mathrm{H}-6,140-150$ & 25.65 & 7.62 & 2.643 & 2.552 & 560.60 & 27.92 & -3.57 & - & 0.69 & 306 & 10.6 & 50.8 & 484 & - & 10.3 & 50.4 & 482.4 & 12.1 & 487 & 93.5 \\
\hline \multicolumn{21}{|l|}{ 329-U1367D- } \\
\hline $2 \mathrm{H}-4,40-50$ & 12.35 & 7.67 & 2.562 & 2.585 & 559.16 & 27.93 & -3.30 & 37.28 & 0.98 & 238 & 10.3 & 54.2 & 483 & - & 10.4 & 51.7 & 476.1 & 10.7 & 457 & 93.3 \\
\hline & 17. & 7.67 & & 2.482 & - & - & - & 36.94 & 0.83 & 267 & 10.8 & 50.6 & 48 & - & 10.8 & 0.8 & 474.0 & 11.0 & 492 & 93.8 \\
\hline $3 \mathrm{H}-2,0-10$ & 18.45 & 7.65 & 2.521 & 2.534 & 560.30 & 27.52 & -4.90 & 36.84 & 1.04 & 261 & 10.6 & 50.9 & 480 & - & 10.8 & 49.4 & 483.9 & 11.4 & 489 & 94.0 \\
\hline $3 \mathrm{H}-3,0-10$ & 19.95 & 7.67 & 2.546 & 2.587 & 560.68 & 27.51 & -5.01 & 37.02 & 1.36 & 399 & 10.8 & - & 486 & - & 10.3 & 48.6 & 487.1 & 12.3 & 503 & 94.1 \\
\hline $3 \mathrm{H}-3,140-150$ & 21.35 & 7.71 & 2.685 & 2.648 & - & - & - & - & 0.97 & 283 & - & 50.3 & 487 & - & 10.8 & 49.7 & 481.2 & 11.6 & 494 & 93.5 \\
\hline $3 \mathrm{H}-4,70$ & 22.15 & 7.65 & 2.571 & 2.572 & 560.11 & 27.43 & -5.17 & 37.01 & 1.08 & 268 & 10.8 & 49.9 & 48 & - & 10.7 & 48.2 & 489.0 & 11.7 & 505 & 93.9 \\
\hline $3 \mathrm{H}-4,140-150$ & 22.85 & 7.67 & 2.576 & 2.567 & 559.30 & 27.00 & -6.54 & 37.16 & 0.82 & 251 & 10.7 & 49.4 & 487 & - & 10.8 & 49.9 & 479.5 & 11.5 & 496 & 92.8 \\
\hline $3 \mathrm{H}-5,70-80$ & 23.65 & 7.67 & 2.497 & 2.528 & 559.64 & 27.40 & -5.20 & 39.01 & 0.98 & 269 & 10.3 & 50.2 & 487 & - & 10.7 & 50.6 & 473.1 & 11.1 & 489 & 92.3 \\
\hline & 24.35 & 7.71 & & 2.757 & 559.71 & 26.87 & -7.05 & - & 1.48 & 314 & 10.8 & 48.3 & 488 & - & & & & & & \\
\hline $3 \mathrm{H}-6,0-10$ & 24.45 & 7.69 & 2.556 & 2.532 & 560.22 & 27.85 & -3.76 & 36.92 & 1.19 & 267 & 10.2 & 51.5 & 484 & - & 10.3 & 48.8 & 482.0 & 11.8 & 479 & 92.5 \\
\hline
\end{tabular}

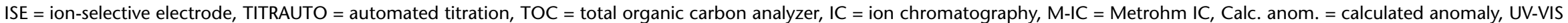
$=$ ultraviolet-visible, Spec. $=$ spectrophotometry, $\mathrm{Dx}-\mathrm{IC}=$ Dionex IC, ICPAES $=$ inductively coupled plasma-atomic emission spectroscopy. $\mathrm{BD}=$ below detection. $-=$ no data. 
Table T13. Solid-phase carbon and nitrogen, Site U1367.

\begin{tabular}{|c|c|c|c|c|c|c|}
\hline $\begin{array}{l}\text { Core, section, } \\
\text { interval }(\mathrm{cm})\end{array}$ & $\begin{array}{l}\text { Depth } \\
\text { (mbsf) }\end{array}$ & $\begin{array}{c}\mathrm{TC} \\
\text { (wt\%) }\end{array}$ & $\begin{array}{c}\mathrm{TN} \\
(\mathrm{wt} \%)\end{array}$ & $\begin{array}{l}\text { TOC } \\
\text { (wt\%) }\end{array}$ & $\begin{array}{c}\text { TIC } \\
\text { (wt\%) }\end{array}$ & $\begin{array}{l}\mathrm{CaCO}_{3} \\
\text { (wt\%) }\end{array}$ \\
\hline \multicolumn{7}{|l|}{ 329-U1367B- } \\
\hline $1 \mathrm{H}-1,0-1$ & 0.01 & 2.79 & 0.029 & 0.17 & 2.53 & 21.04 \\
\hline $1 \mathrm{H}-1,10-11$ & 0.11 & 1.21 & 0.026 & 0.14 & 1.02 & 8.52 \\
\hline $1 \mathrm{H}-1,25-26$ & 0.26 & 0.35 & 0.025 & 0.12 & 0.21 & 1.76 \\
\hline $1 \mathrm{H}-1,45-46$ & 0.46 & 0.19 & 0.015 & 0.10 & 0.10 & 0.80 \\
\hline $1 \mathrm{H}-1,68-69$ & 0.69 & 0.16 & 0.015 & 0.07 & 0.09 & 0.72 \\
\hline $1 \mathrm{H}-1,99-100$ & 1.00 & 0.15 & 0.014 & 0.07 & 0.08 & 0.67 \\
\hline $1 \mathrm{H}-2,100-101$ & 2.51 & 0.13 & 0.008 & 0.06 & 0.08 & 0.71 \\
\hline $1 \mathrm{H}-3,100-101$ & 4.01 & 0.14 & 0.005 & 0.03 & 0.13 & 1.06 \\
\hline $1 \mathrm{H}-4,90-91$ & 5.41 & 0.69 & 0.004 & 0.04 & 0.65 & 5.41 \\
\hline $2 \mathrm{H}-1,147-148$ & 6.98 & 10.90 & BD & 0.02 & 10.93 & 91.09 \\
\hline $2 \mathrm{H}-2,147-148$ & 8.48 & 11.16 & $\mathrm{BD}$ & 0.03 & 11.35 & 94.55 \\
\hline $2 \mathrm{H}-3,147-148$ & 9.98 & 10.65 & $\mathrm{BD}$ & 0.01 & 10.92 & 90.95 \\
\hline $2 \mathrm{H}-4,147-148$ & 11.48 & 10.69 & $\mathrm{BD}$ & 0.01 & 10.73 & 89.37 \\
\hline $2 \mathrm{H}-5,120-121$ & 12.71 & 10.12 & $\mathrm{BD}$ & 0.02 & 10.18 & 84.78 \\
\hline $3 \mathrm{H}-1,135-136$ & 14.86 & 9.19 & $\mathrm{BD}$ & 0.02 & 9.38 & 78.17 \\
\hline $3 \mathrm{H}-2,135-136$ & 16.36 & 9.63 & $\mathrm{BD}$ & 0.02 & 9.58 & 79.78 \\
\hline $3 \mathrm{H}-3,135-136$ & 17.86 & 9.28 & $\mathrm{BD}$ & 0.01 & 9.49 & 79.01 \\
\hline $3 \mathrm{H}-4,14-15$ & 18.15 & 9.60 & $\mathrm{BD}$ & 0.01 & 9.52 & 79.29 \\
\hline $3 \mathrm{H}-5,135-136$ & 20.86 & 10.53 & $\mathrm{BD}$ & 0.01 & 10.80 & 89.95 \\
\hline $3 \mathrm{H}-6,76-77$ & 21.77 & 10.03 & $\mathrm{BD}$ & 0.01 & 9.92 & 82.65 \\
\hline
\end{tabular}

$\mathrm{TC}=$ total carbon, $\mathrm{TN}=$ total nitrogen, $\mathrm{TOC}=$ total organic carbon, $\mathrm{TIC}=$ total inorganic carbon. $\mathrm{BD}=$ below detection $(\mathrm{TN}<0.001 \%)$. 
Table T14. Epifluorescence microscopy cell counts for sediment samples, Site U1367.

\begin{tabular}{|c|c|c|c|c|c|}
\hline \multirow{3}{*}{$\begin{array}{l}\text { Core, section, } \\
\text { interval }(\mathrm{cm})\end{array}$} & \multirow{3}{*}{$\begin{array}{l}\text { Depth } \\
\text { (mbsf) }\end{array}$} & \multicolumn{4}{|c|}{ Cell count $\left(\log _{10}\right.$ cells $\left./ \mathrm{cm}^{3}\right)$} \\
\hline & & \multicolumn{2}{|c|}{ Extracted } & \multicolumn{2}{|c|}{ Nonextracted } \\
\hline & & Count 1 & Count 2 & Count 1 & Count 2 \\
\hline \multicolumn{6}{|l|}{ 329-U1365C- } \\
\hline $1 \mathrm{H}-1,10-20$ & 0.10 & 5 & 5 & 5.7 & 5.6 \\
\hline $1 \mathrm{H}-1,60-70$ & 0.60 & & & 5.2 & 4.5 \\
\hline $1 \mathrm{H}-1,110-120$ & 1.10 & & & & \\
\hline $1 \mathrm{H}-1,135-140$ & 1.35 & & & & \\
\hline $1 \mathrm{H}-2,60-70$ & 2.10 & 3.5 & 3.1 & BD & BD \\
\hline $1 \mathrm{H}-2,110-120$ & 2.60 & & & & \\
\hline $1 \mathrm{H}-3,60-70$ & 3.60 & 2.7 & 3.1 & & \\
\hline $1 \mathrm{H}-3,110-120$ & 4.10 & & & & \\
\hline $1 \mathrm{H}-3,135-140$ & 4.35 & & & & \\
\hline $1 \mathrm{H}-4,60-70$ & 5.10 & 2.3 & 2.3 & & \\
\hline $1 \mathrm{H}-4,150-150$ & 5.90 & & & & \\
\hline $1 \mathrm{H}-5,60-70$ & 6.60 & & & & \\
\hline $1 \mathrm{H}-5,135-140$ & 7.35 & & & & \\
\hline $2 \mathrm{H}-1,60-70$ & 7.80 & 2.6 & 2.3 & & \\
\hline $2 \mathrm{H}-1,110-120$ & 8.30 & & & & \\
\hline $2 \mathrm{H}-1,145-150$ & 8.65 & & & & \\
\hline $2 \mathrm{H}-2,60-70$ & 9.30 & 2.7 & 2.7 & & \\
\hline $2 \mathrm{H}-2,110-120$ & 9.80 & & & & \\
\hline $2 \mathrm{H}-3,60-70$ & 10.80 & 2.8 & 2.8 & & \\
\hline $2 \mathrm{H}-3,110-120$ & 11.30 & & & & \\
\hline $2 \mathrm{H}-3,145-150$ & 11.65 & & & & \\
\hline $2 \mathrm{H}-4,60-70$ & 12.30 & 1.9 & BD & & \\
\hline $2 \mathrm{H}-4,110-120$ & 12.80 & & & & \\
\hline $2 \mathrm{H}-5,60-70$ & 13.80 & 3 & 2.8 & & \\
\hline $2 \mathrm{H}-5,110-120$ & 14.30 & & & & \\
\hline $2 \mathrm{H}-5,145-150$ & 14.65 & & & & \\
\hline $2 \mathrm{H}-6,60-70$ & 15.30 & 3.2 & BD & & \\
\hline $2 \mathrm{H}-6,110-120$ & 15.80 & & & & \\
\hline $2 \mathrm{H}-7,50-60$ & 16.70 & 3.1 & 2.4 & & \\
\hline $3 \mathrm{H}-1,50-60$ & 17.20 & & & & \\
\hline $3 \mathrm{H}-1,110-120$ & 17.80 & & & & \\
\hline $3 \mathrm{H}-2,0-5$ & 18.20 & 2.8 & 2.9 & & \\
\hline $3 \mathrm{H}-2,60-70$ & 18.80 & & & & \\
\hline $3 \mathrm{H}-2,110-120$ & 19.30 & & & & \\
\hline $3 \mathrm{H}-3,60-70$ & 20.30 & 2.9 & 2.5 & & \\
\hline $3 \mathrm{H}-3,110-120$ & 20.80 & & & & \\
\hline $3 \mathrm{H}-4,60-70$ & 21.80 & 3.4 & 2.3 & & \\
\hline $3 \mathrm{H}-4,110-120$ & 22.30 & & & & \\
\hline $3 \mathrm{H}-6,0-5$ & 24.20 & 2.6 & 2.4 & & \\
\hline \multicolumn{6}{|l|}{ 329-U1365D- } \\
\hline $2 \mathrm{H}-4,50-60$ & 12.40 & & & & \\
\hline $3 \mathrm{H}-1,80-90$ & 17.70 & & & & \\
\hline $3 \mathrm{H}-2,10-20$ & 18.50 & & & & \\
\hline $3 \mathrm{H}-3,10-20$ & 20.00 & & & & \\
\hline $3 \mathrm{H}-3,135-140$ & 21.25 & & & & \\
\hline $3 \mathrm{H}-4,80-90$ & 22.20 & & & & \\
\hline $3 \mathrm{H}-4,135-140$ & 22.75 & & & & \\
\hline $3 \mathrm{H}-5,80-90$ & 23.70 & & & & \\
\hline $3 \mathrm{H}-5,135-140$ & 24.25 & & & & \\
\hline $3 \mathrm{H}-6,10-20$ & 24.50 & & & & \\
\hline $3 \mathrm{H}-\mathrm{CC}, 0-3$ & 25.11 & & & & \\
\hline $4 \mathrm{H}-\mathrm{CC}, 23-25$ & 25.43 & & & & \\
\hline $\begin{array}{r}\text { 329-U1365E- } \\
3 \mathrm{H}-\mathrm{CC}, 0-2\end{array}$ & 24.17 & & & & \\
\hline
\end{tabular}

$\mathrm{BD}=$ below detection. Blank cells = no counts (will be counted postexpedition). 
Table T15. Epifluorescence microscopy cell and microsphere bead counts in basaltic rock samples, Site U1367.

\begin{tabular}{|c|c|c|c|c|c|c|c|c|}
\hline \multirow[b]{2}{*}{$\begin{array}{l}\text { Core, } \\
\text { section }\end{array}$} & \multirow[b]{2}{*}{ Basalt type } & \multirow[b]{2}{*}{$\begin{array}{l}\text { Depth } \\
\text { (mbsf) }\end{array}$} & \multirow[b]{2}{*}{$\begin{array}{c}\text { Cell count } \\
\left(\log _{10} \text { cells } / \mathrm{cm}^{3}\right)\end{array}$} & \multicolumn{5}{|c|}{ Microsphere count $\left(\log _{10}\right.$ microspheres $\left./ \mathrm{cm}^{3}\right)$} \\
\hline & & & & $\begin{array}{l}\text { Washing } \\
\text { solution }\end{array}$ & $\begin{array}{l}\text { Exterior } \\
\text { untreated }\end{array}$ & $\begin{array}{c}\text { Exterior } \\
\text { washed } 2 x\end{array}$ & $\begin{array}{l}\text { Exterior } \\
\text { flamed }\end{array}$ & Interior \\
\hline \multicolumn{9}{|c|}{ 329-U1365D- } \\
\hline $3 \mathrm{H}-\mathrm{CC}$ & Interface & 25.2 & 5.0 & NA & NA & NA & NA & NA \\
\hline \multicolumn{9}{|c|}{ 329-U1365F- } \\
\hline $4 \mathrm{R}-1$ & Basement & 36.6 & ND & 4.8 & 4.5 & 4.6 & 3.8 & ND \\
\hline 6R-1 & Basement without veins & 51.2 & 4.6 & 5.4 & 3.9 & 3.5 & 4.3 & 3.6 \\
\hline 6R-1 & Basement with veins & 51.2 & 5.2 & 5.4 & 3.9 & 3.5 & 4.3 & 3.6 \\
\hline
\end{tabular}

$\mathrm{NA}=$ not applicable (no delivery of microspheres into the borehole), ND = no cells or microspheres observed by microscopic observations.

Table T16. Abundance of virus-like particles in sediment samples by epifluorescence microscopy, Site U1367.

\begin{tabular}{|c|c|c|c|}
\hline $\begin{array}{l}\text { Core, } \\
\text { section }\end{array}$ & $\begin{array}{c}\text { Depth } \\
\text { (mbsf) }\end{array}$ & $\mathrm{VLP} / \mathrm{cm}^{3}$ & STD \\
\hline \multicolumn{4}{|c|}{ 329-U1367D- } \\
\hline $1 \mathrm{H}-1$ & 0.0 & $7.49 \mathrm{E}+05$ & $4.30 \mathrm{E}+04$ \\
\hline $1 \mathrm{H}-1$ & 1.20 & $2.12 \mathrm{E}+05$ & $1.33 \mathrm{E}+04$ \\
\hline $1 \mathrm{H}-1$ & 1.20 & $1.71 \mathrm{E}+05$ & $1.20 \mathrm{E}+04$ \\
\hline $1 \mathrm{H}-1$ & 1.40 & & \\
\hline $1 \mathrm{H}-2$ & 2.80 & & \\
\hline $1 \mathrm{H}-3$ & 3.50 & & \\
\hline $1 \mathrm{H}-4$ & 4.80 & & \\
\hline $1 \mathrm{H}-5$ & 6.45 & & \\
\hline $2 \mathrm{H}-1$ & 7.80 & & \\
\hline $2 \mathrm{H}-2$ & 9.60 & $7.19 \mathrm{E}+04$ & $6.73 \mathrm{E}+03$ \\
\hline $2 \mathrm{H}-2$ & 9.60 & $8.76 \mathrm{E}+04$ & $7.43 \mathrm{E}+03$ \\
\hline $2 \mathrm{H}-2$ & 9.80 & & \\
\hline $2 \mathrm{H}-3$ & 10.70 & & \\
\hline $2 \mathrm{H}-4$ & 12.20 & & \\
\hline $2 \mathrm{H}-5$ & 13.60 & & \\
\hline $2 \mathrm{H}-6$ & 15.20 & & \\
\hline $3 \mathrm{H}-1$ & 17.40 & $4.41 \mathrm{E}+03$ & $1.18 \mathrm{E}+03$ \\
\hline $3 \mathrm{H}-1$ & 17.80 & & \\
\hline $3 \mathrm{H}-2$ & 18.90 & & \\
\hline $3 \mathrm{H}-3$ & 20.20 & & \\
\hline $3 \mathrm{H}-4$ & 21.90 & & \\
\hline $3 \mathrm{H}-5$ & 22.90 & & \\
\hline $3 \mathrm{H}-6$ & 24.90 & & \\
\hline \multicolumn{4}{|c|}{ 329-U1367C- } \\
\hline $1 \mathrm{H}-1$ & 0.00 & & \\
\hline $1 \mathrm{H}-1$ & 0.60 & & \\
\hline $1 \mathrm{H}-2$ & 2.10 & & \\
\hline $1 \mathrm{H}-3$ & 3.60 & & \\
\hline $1 \mathrm{H}-4$ & 5.10 & & \\
\hline $1 \mathrm{H}-5$ & 6.60 & & \\
\hline $2 \mathrm{H}-1$ & 7.80 & & \\
\hline $2 \mathrm{H}-2$ & 9.30 & & \\
\hline $2 \mathrm{H}-3$ & 10.80 & & \\
\hline $2 \mathrm{H}-4$ & 12.30 & & \\
\hline $2 \mathrm{H}-5$ & 13.80 & & \\
\hline $2 \mathrm{H}-6$ & 15.30 & & \\
\hline $2 \mathrm{H}-7$ & 16.70 & & \\
\hline $3 \mathrm{H}-1$ & 17.20 & & \\
\hline $3 \mathrm{H}-2$ & 18.80 & & \\
\hline $3 \mathrm{H}-3$ & 20.30 & & \\
\hline $3 \mathrm{H}-4$ & 21.80 & & \\
\hline
\end{tabular}

VLP $=$ virus-like particle, STD $=$ standard deviation. Blank cells $=$ no counts (samples will be analyzed postexpedition). 
Table T17. List of samples and culture media used for onboard cultivation experiments, Site U1367.

\begin{tabular}{cl}
\hline $\begin{array}{c}\text { Core, } \\
\text { section }\end{array}$ & \multicolumn{1}{c}{ Media used for cultivation } \\
\hline $1 \mathrm{H}-1$ & Mmm1, Mmm2, SPG-ASW, SPG-JL, MA, MR2A, SLURRY \\
$1 \mathrm{H}-2$ & SPG-JL, MA, MR2A \\
$1 \mathrm{H}-3$ & MA, MR2A \\
$1 \mathrm{H}-4$ & MA, MR2A \\
$2 \mathrm{H}-2$ & Mmm1, Mmm2, SPG-ASW, SPG-JL, MA, MR2A, SLURRY \\
$3 \mathrm{H}-1$ & Mmm1, Mmm2, SPG-ASW, SPG-JL, MA, MR2A, SLURRY \\
$3 \mathrm{H}-5$ & Mmm1, Mmm2, SPG-ASW, SPG-JL, MA, MR2A, SLURRY \\
4R-1 & Mmm1, Mmm2, SPG-ASW \\
\hline
\end{tabular}

SLURRY = slurry in artificial seawater. For more detailed information on the media, see "Microbiology" in the "Methods" chapter (Expedition 329 Scientists, 2011a). 


\section{Appendix}

\section{Foraminifer and ostracod taxa}

\section{Benthic foraminifers}

Globocassidulina subglobosa (Brady) 1881

Cibicidoides sp.

Dentalina spp.

Gyroidinoides soldanii (d'Orbigny) 1826

Karreriella chapapotensis (Cushman) 1911

Lagena spp.

Lenticulina gibba d'Orbigny, 1826

Nodosaria sp. A

Nodosaria sp. B

Nodosaria sp. C

Nuttallides umbonifer (Cushman) 1933

Oridorsalis umbonatus (Reuss) 1851

Pleurostomella sp.

Siphonodosaria antillea Cushman, 1933

Siphonodosaria spinata Deshayes, 1832

Textularia sp.

Vulvulina spinosa Cushman, 1927

\section{Ostracods}

Argilloecia

Australoecia micra Bonaduce et al., 1975

Bairdoppilata

Bradleya

Cytheropteron

Cytherella

Eucythere

Heinia

Hemiparacytheridea mediopunctata Coles and Whatley

Henryhowella asperrima Reuss, 1850
Krithe

Paranesidea

Pariceratina

Pedicythere

Pelecocythere

Poseidonamicus dinglei Boomer, 1999

Poseidonamicus sp.

Pseudobosquetina mucronalatum Brady, 1880

Xylocythere?

\section{Planktonic foraminifers}

Catapsydrax dissimilis (Cushman and Bermudez, 1937) Bolli, Loeblich, and Tappan, 1957

Cassigerinella chipolensis Cushman and Ponton, 1932

Chiloguembelina cubensis (Palmer, 1934) Beckmann, 1957

Globigerina euapertura Jenkins, 1960

Globigerina praebulloides Blow, 1959

Globigerina pseudovenezuelana Blow and Banner, 1962

Globigerina tapurensis Blow and Banner, 1962

Subbotina eocaena Gembel, 1868

Subbotina linaperta Finlay, 1939

Subbotina gortani (Borsetti) Bolli and Saunders, 1985

Paragloborotalia nana Bolli, 1957

Paragloborotalia opima (Bolli, 1957) Spezzaferri and Silva, 1990

Pseudohastigerina micra Cole, 1927

Pseudohastigerina naguewichiensis (Myatliuk, 1950) Blow, 1969

Tenuitellianata angustiumbilicata Bolli, 1957

Tenuitellianata gemma 